RPP-RPT-54914, Rev. 0

\title{
Hanford Single-Shell Tank Leak Causes and Locations - 241-C Farm
}

\section{C.L. Girardot, D.G. Harlow}

Washington River Protection Solutions

Richland, WA 99352

U.S. Department of Energy Contract DE-AC27-08RV14800

$\begin{array}{lll}\text { EDT/ECN: } & \text { DRF } & \text { UC: N/A } \\ \text { Cost Center: } & \text { 2KE00 } & \text { Charge Code: } 201334 \\ \text { B\&R Code: } & \text { N/A } & \text { Total Pages: } 144\end{array}$

Key Words: leak location, leak cause, tank, integrity assessment, C Farm, C-101, C-105, leak assessment

Abstract: This document identifies 241-C Tank Farm (C Farm) leak causes and locations for the 100 series leaking tanks (241-C-101 and 241-C-105) identified in RPP-RPT-33418, Rev. 2, Hanford C-Farm Leak Inventory Assessments Report. This document satisfies the C Farm portion of the target (T04) in the Hanford Federal Facility Agreement and Consent Order milestone M-045-91F.

TRADEMARK DISCLAIMER. Reference herein to any specific commercial product, process, or service by trade name, trademark, manufacturer, or otherwise, does not necessarily constitute or imply its endorsement, recommendation, or favoring by the United States Government or any agency thereof or its contractors or subcontractors.

APPROVED

By G.E. Bratton at 3:37 pm, Jul 30, 2013

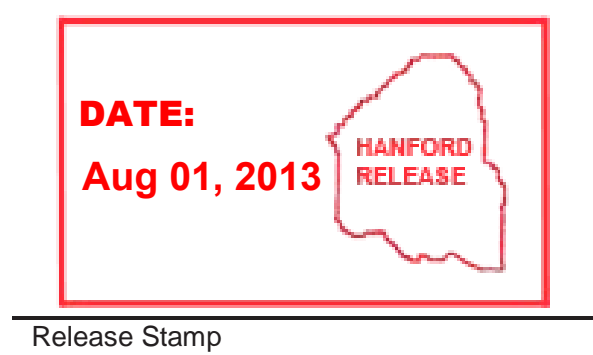

\section{Approved For Public Release}




\section{EXECUTIVE SUMMARY}

This document identifies 241-C Tank Farm (C Farm) leak causes and locations for the 100-series leaking tanks in $\mathrm{C}$ Farm. The leak causes and locations report for all of the 100-series singleshell leaking tanks is one of the targets (M-045-91-T04) in the Hanford Federal Facility Agreement and Consent Order milestone M-045-91F. The T04 target requires that the DOE provide to State of Washington, Department of Ecology (Ecology) a report on the 100-series single-shell tanks which have been or will be identified as having leaked in RPP-32681, Rev. 0, Process to Assess Tank Farm Leaks in Support of Retrieval and Closure Planning, leak assessment reports.

The leak assessment report for C Farm, RPP-RPT-33418, Rev, 2, Hanford C-Farm Leak Inventory Assessments Report, lists two 100-series tanks that either continue to be or are recommended to be classified leaking tanks in C Farm, 241-C-101 (C-101) and 241-C-105 (C105) respectively. All of the other ten 100-series tanks in C Farm are classified as "sound" or are identified in RPP-RPT-33418, Rev, 2, as requiring re-assessment of their classification per TFCENG-CHEM-D-42, Tank Leak Assessment Process. The TFC-ENG-CHEM-D-42 assessments are not part of the M-045-91-T04 target.

This C Farm leak causes and locations document is part of a series of tank farm reports that identify leak causes and locations for 100-series leaking tanks. A summary and conclusions document will be issued, RPP-RPT-54909, Hanford Single-Shell Tank Leak Causes and Locations - Summary, that compiles the results from all of the leak causes and locations tank farm reports when they have been issued which will fulfill the T04 target requirements.

The identification of C Farm tank leak locations focused on the vertical indication of a sidewall leak from liquid level decreases and the radial as well as vertical direction indicated by radiation detected in drywells. The tank C-101 liner may have leaked near the west portion of the tank, possibly in the tank sidewall, based on the radioactivity in drywell 30-01-09 or the capped spare inlet nozzles could also be a source of drywell 30-01-09 radioactivity. The liquid level analysis points to spare inlet line packing leaks.

The tank C-105 liner may have leaked at or near the tank footing in either one or two locations based on radioactivity detected in the drywells. However, the proximity of the capped spare inlet nozzles, cascade inlet, Line V103, and the condenser could also be a cause of the radioactivity. If the liner leaked, the leaks may have penetrated the waterproof membrane at any point and followed concrete cracks or construction joints to exit at a different location including the top of the tank footing.

There are several liner leak cause conditions that were examined but the most likely cause of a tank C-101 or tank C-105 leak was chemistry-corrosion as it relates to the storage of TBP process wastes. The TBP process waste is conducive to pitting and stress corrosion cracking (SCC). In addition, tank C-105 waste types PSS and possibly RSN at elevated temperatures could have contributed to an environment conducive to SCC to a lesser degree. 


\section{RPP-RPT-54914, Rev. 0}

There appears to be very little contribution from tank design, construction temperatures, and thermal conditions. However, some or all of the factors can act serially or together to contribute to tank liner failure. 


\section{TABLE OF CONTENTS}

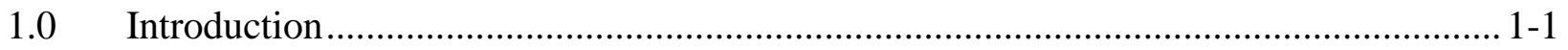

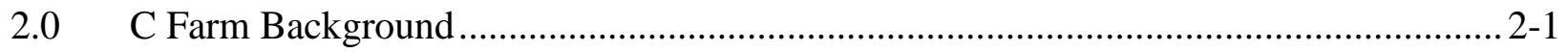

3.0 C Farm Commonalities ................................................................................ $3-2$

3.1 Tank Design/Construction ........................................................................ 3-2

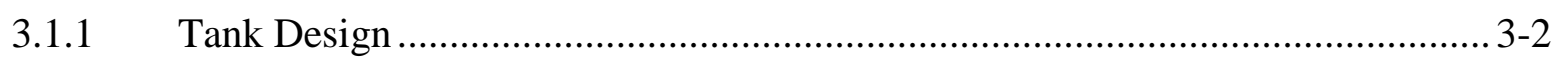

3.1.2 Tank Construction Conditions ................................................................... 3-3

3.2 In-Tank Data For Leaking C Farm Tanks ..................................................... 3-4

3.2.1 Liquid Level................................................................................. $3-4$

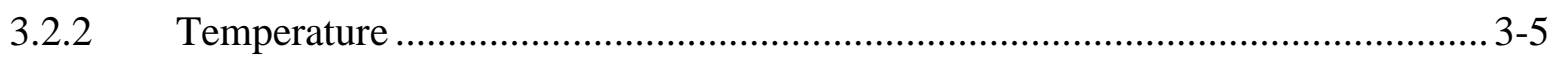

3.2.3 Liner Observations .......................................................................... $3-6$

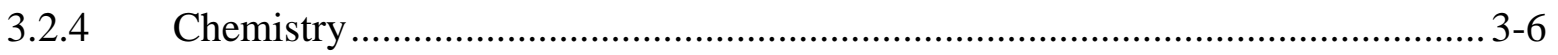

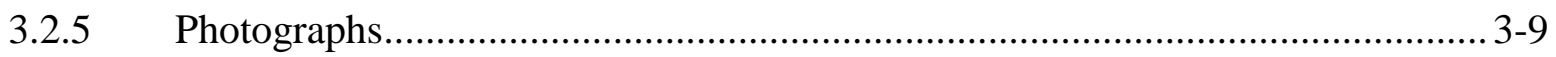

3.3 Ex-Tank Data For Leaking C Farm Tanks ............................................................... 3-9

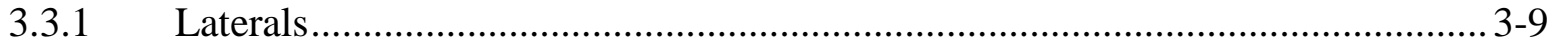

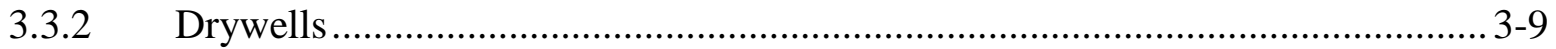

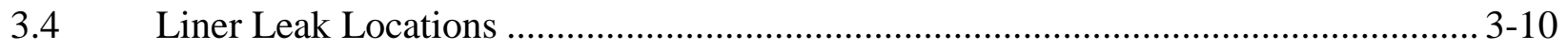

3.5 Possible Liner Leak Cause(s) ..................................................................... 3-11

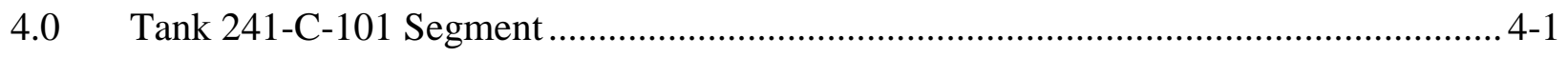

5.0 Tank 241-C-105 Segment .............................................................................. 5-1

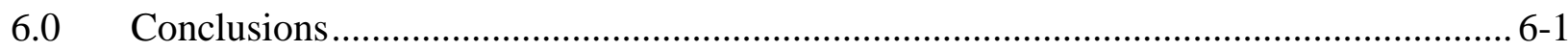

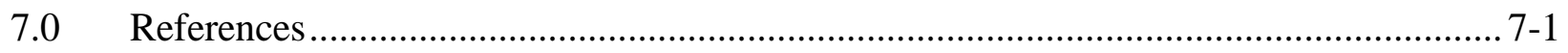

\section{Appendices}

Appendix A Meeting Minutes ................................................................................... A-1 


\section{RPP-RPT-54914, Rev. 0}

\section{LIST OF FIGURES}

Figure 2-1. C Farm and Associated Drywells.............................................................. 2-1

Figure 3-1. B C T U Tank Farm Knuckle Configuration with Three-ply Waterproofing (BPF-73550, Sheet B5) ............................................................................. 3-2

Figure 3-2. C Farm Construction Photograph (P3490 N1585559)..................................... 3-3

\section{LIST OF TABLES}

Table 2-1. Leaking C Farm Tanks with Waste Type .......................................................... 2-2

Table 3-1. ARH-1601 Specifications 1973 ................................................................. 3-8

Table 6-1. C Farm Leaking Tanks ............................................................................ 6-3

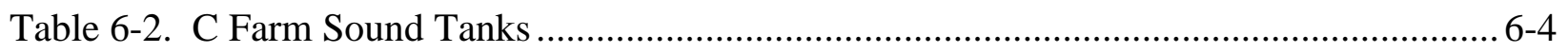




\section{Acronyms and Abbreviations}

\begin{tabular}{|c|c|}
\hline $221-U$ & TBP Plant \\
\hline 221-B & B Plant \\
\hline 241-C Farm & C Farm \\
\hline 241-T Farm & T Farm \\
\hline ARHCO & Atlantic Richfield Hanford Company \\
\hline BGS & below grade surface \\
\hline cpm & counts per minute \\
\hline $\mathrm{c} / \mathrm{s}, \mathrm{cps}$ & counts per second \\
\hline GM & Geiger-Mueller probe \\
\hline LL & liquid level \\
\hline MT & manual tape \\
\hline $\mathrm{NaI}$ & sodium-iodide \\
\hline $\mathrm{NO}_{2}^{-}$ & nitrite \\
\hline $\mathrm{NO}_{3}^{-}$ & nitrate \\
\hline $\mathrm{OCP}$ & open circuit potential \\
\hline $\mathrm{OH}^{-}$ & hydroxide \\
\hline PCSACS & PC Surveillance Analysis Computer System \\
\hline PUREX & Plutonium Uranium Extraction Plant \\
\hline REDOX & Reduction Oxidation Plant \\
\hline SCC & stress corrosion cracking \\
\hline SGLS & Spectral Gamma Logging System \\
\hline SP & scintillation probe \\
\hline SSP & shielded scintillation probe \\
\hline $\mathrm{SST}(\mathrm{s})$ & single-shell tank(s) \\
\hline TWINS & Tank Waste Information Network System \\
\hline UNH & uranyl nitrate hexahydrate \\
\hline WRPS & Washington River Protection Solutions, LLC \\
\hline \multicolumn{2}{|l|}{ Units } \\
\hline $\mathrm{Ci}$ & curie \\
\hline${ }^{\circ} \mathrm{F}$ & degrees Fahrenheit \\
\hline $\mathrm{ft}$ & feet \\
\hline gal & gallon \\
\hline $\mathrm{K}$ & 1000 \\
\hline kgal & kilogallon $\left(10^{3}\right.$ gallons $)$ \\
\hline in & inches \\
\hline $\mathrm{L}$ & liter \\
\hline M & moles per liter \\
\hline $\mathrm{pCi}$ & picocurie $\left(10^{-12}\right.$ curies $)$ \\
\hline $\mathrm{pCi} / \mathrm{g}$ & picocurie per gram \\
\hline yr & year \\
\hline
\end{tabular}




\section{RPP-RPT-54914, Rev. 0}

\section{Waste Type Abbreviations}

1C first cycle decontamination waste (form fuels reprocessing plant)

5-6 high-level B Plant waste

BL B Plant Low Level Waste

BNW Battelle Northwest Laboratory

CWP PUREX coating waste

EB Evaporator Bottoms

FeCN Ferrocyanide Waste

FP

fission products waste

HLO HEDL Laboratory Operations (300 Area Wastes)

HLW high-level waste

IX Ion Exchange waste

LW 222-S Laboratory waste

MW Metal waste

OWW PUREX organic wash waste

PSS PUREX sludge supernatant

RSN REDOX neutralized supernatant

RIX REDOX ion exchange loading waste

TBP Tri-butyl phosphate waste 


\subsection{INTRODUCTION}

The Hanford Federal Facility Agreement and Consent Order target M-045-91F-T04 indicated that part of the RPP-32681, Process to Assess Tank Farm Leaks in Support of Retrieval and Closure Planning, reporting would include leak causes and locations reports for all of the 100-series single-shell leaking tanks. This document is part of a series of documents that identifies leak causes and locations of 100-series single-shell leaking tanks that have been identified in the individual RPP-32681 tank farm leak assessments. An overall leak causes and locations summary and conclusions document will be prepared along with background and common tank farm information when all of the 100-series single-shell leaking tanks have been addressed (RPP-RPT-54909, Hanford Single-Shell Tank Leak Causes and Locations - Summary and Conclusion, to be issued). The information from RPP-RPT-54909 will be incorporated into the summary conclusions report on leak integrity for the Hanford Federal Facility Agreement and Consent Order milestone M-045-91F.

The 241-C Tank Farm (C Farm) tanks with a leak loss are addressed in this document. The C Farm assessment in RPP-ENV-33418, Rev. 1, Hanford C-Farm Leak Assessment Report: 241-C101, 241-C-110, 241-C-111, 241-C-105, and Unplanned Waste Releases, re-assessed the tank loss events for Single-Shell Tanks (SSTs) 241-C-101 (C-101), 241-C-110 (C-110), and 241-C111 (C-111), which had previously been designated as suspected of having leaked waste to the ground. Information on contamination in the soil surrounding tank 241-C-105 (C-105) was also reviewed. The RPP-ENV-33418, Rev. 1, assessment stated that:

- the tank C-101 leak estimate of $20 \mathrm{kgal}$ should not be changed,

- a leak at the tank C-110 spare inlet lines was the most probable source of drywell radiation,

- the team indicated data supported reclassifying the tank C-111 as sound,

- the contamination below the tank C-105 base was estimated to represent 40 gal to $2 \mathrm{kgal}$.

The C Farm assessment was updated in November 2011, RPP-ENV-33418, Rev. 2, Hanford CFarm Leak Assessments Report, reclassifying three of the tanks as well as updating inventory estimates for tank leaks and other releases from C Farm. Tank C-101 continued as a confirmed leaker with a recommendation to assess the tank using the TFC-ENG-CHEM-D-42, Tank Leak Assessment Process, procedure. Tanks C-105, C-110, and C-111 were recommended to be reclassified based on the following TFC-ENG-CHEM-D-42 assessment documentation:

\begin{tabular}{|c|c|c|}
\hline Tank & TFC-ENG-CHEM-D-42 & Reclassification Recommendation \\
\hline C-105 & RPP-ASMT-46452 & Assumed Leaker \\
\hline C-110 & RPP-ASMT-38219 & Sound \\
\hline C-111 & RPP-ASMT-39155 & Sound \\
\hline
\end{tabular}


As a result of the RPP-32681 process and TFC-ENG-CHEM-D-42 procedure, tanks C-101 continues to be classified as "Assumed Leaker" and C-105 is to be changed to "Assumed Leaker", both were analyzed for leak causes and locations addressed in this report. A formal leak assessment of tank C-101 was not required.

The identification of C Farm tank leak locations focused on the first indication of radiation detected in drywells as well as liquid level decreases as appropriate. Leak detection laterals were not installed underneath the $\mathrm{C}$ Farm tanks.

If the C Farm tank liners leaked the most likely cause was due to chemistry-corrosion. There appears to be very little contribution from tank design, thermal conditions, and construction temperatures.

Two meetings were held to review status of tanks C-101 and C-105 with the Office of River Protection (ORP) and the State of Washington, Department of Ecology (Ecology) personnel. A review on April 24, 2013, covered the information that had been generated on the location of the tank C-101 leak and supporting data. A second meeting on May 29, 2013, provided a review of the tank C-105 leak causes and locations document along with a comparison of the available information on the other $\mathrm{C}$ Farm tanks. Comments were received, responses developed, and additions/revisions were made to the document (see Appendix A). 


\subsection{FARM BACKGROUND}

The C Farm was constructed between 1943 and 1944 and is located west of Canton Avenue and north of $7^{\text {th }}$ Street in the 200 East Area. The farm includes twelve 100-series type II, 530,000 gal 100-series dish bottom design SSTs (WHC-SD-WM-ER-313, Rev. 1B, Supporting Document for the Historical Content Estimate for C-Tank Farm, April 1997). A typical 100 series tank in C Farm contains 10 to 12 risers ranging in size from 4-in to 42-in in diameter that provide gradelevel access to the underground tank. Normally, there is one riser in the center of the tank dome and four or five each on opposite sides of the dome. The tanks are arranged in four rows of three tanks forming a cascade. The cascade overflow height is $\sim 15.9-\mathrm{ft}$ from the tank knuckle bottom and $2.0-\mathrm{ft}$ below the top of the steel liner.

Figure 2-1 shows a schematic of the C Farm tanks with location of the drywells.

Figure 2-1. C Farm and Associated Drywells

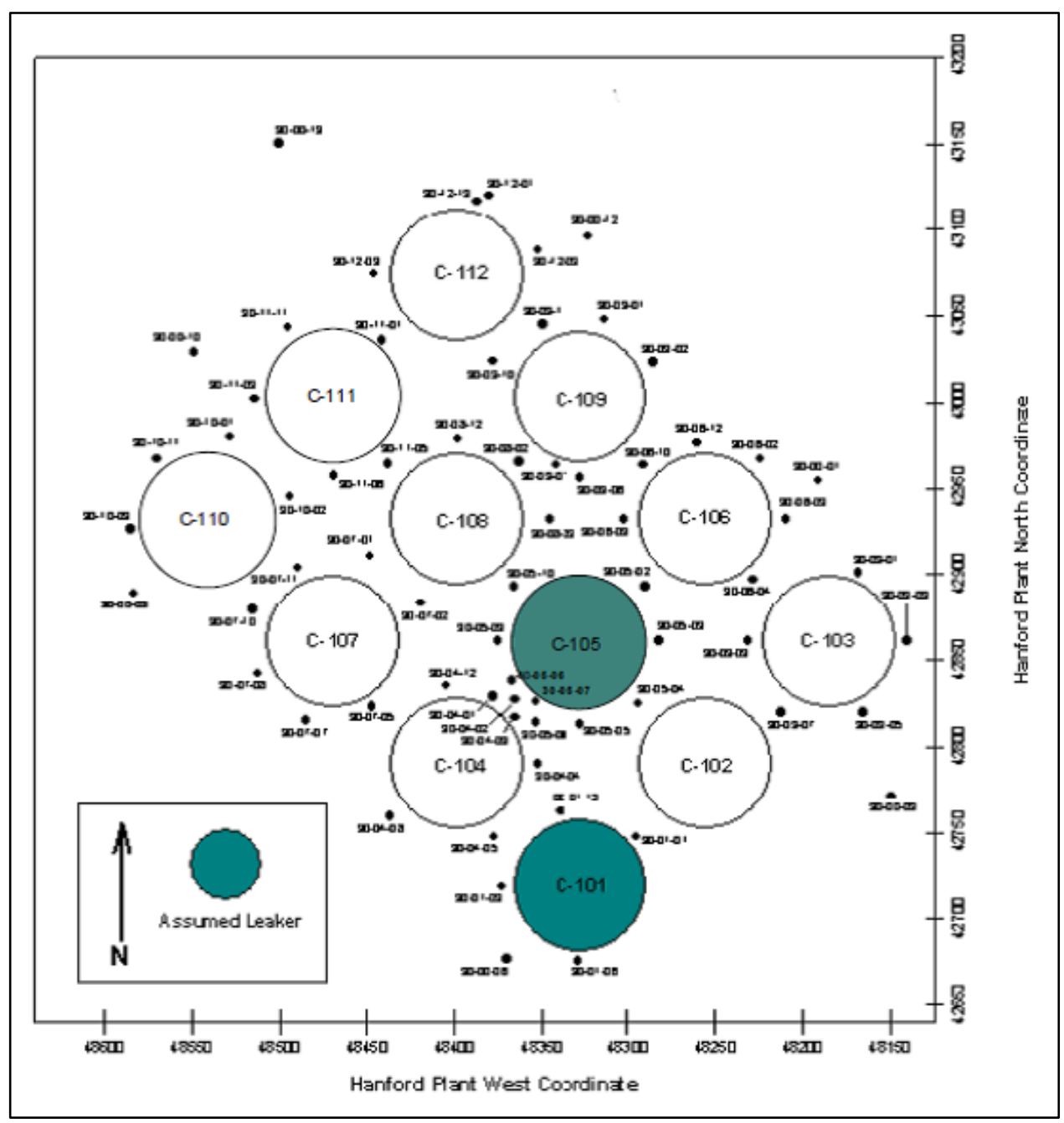

Note: The leak integrity status of tanks C-105, C-110, and C-111 have been updated in this figure to reflect conclusions from the TFC-ENG-CHEM-D-42 procedure which differs from what is reported in HNF-EP-0182, Rev. 299. 
Tanks C-101 and C-105 contained various waste types throughout operation which are listed in Table 2-1. The following sections describe some of the important common tank features and conditions that could affect tank leak causes and locations. This is followed by the individual tank analyses of the possible leak locations and causes and a comparison of leaking and nonleaking tanks in the conclusion section.

Table 2-1. Leaking C Farm Tanks with Waste Type

\begin{tabular}{|c|l|}
\hline Tank & \multicolumn{1}{|c|}{ Waste Type $^{1}$} \\
\hline C-101 & MW, TBP, CWP, PUREX HLW, FeCN \\
\hline C-105 & MW, TBP, CWP, PUREX HLW, RSN, IX, PSS \\
\hline
\end{tabular}

1. Waste types are listed in the List of Terms

\subsection{FARM COMMONALITIES}

\subsection{TANK DESIGN/CONSTRUCTION}

\subsubsection{Tank Design}

The C Farm SSTs are constructed of 1-ft thick reinforced concrete with a 0.25 -in mild carbon steel liner (ASTM A7-39) on the bottom and sides with knuckle plates at 0.3125-in and a 1.25-ft thick domed concrete top. The tanks have a dished bottom with a 4-ft radius knuckle and a 15-ft operating depth from the tank knuckle bottom.

The tanks are set on a reinforced concrete foundation. A three-ply fabric waterproofing was applied over the foundation. Four coats of primer paint were sprayed on all exposed interior tank surfaces. Tank ceiling domes were covered with three applications of magnesium zincfluorosilicate wash. Lead flashing was used to protect the joint where the steel liner meets the concrete dome. Asbestos gaskets were used to seal the access holes in the tank dome. The tanks were waterproofed on the sides and top on the outside of the steel liners with tar and a cement-like sealant. Each tank was covered with $\sim 5.5$-ft of overburden.

The tanks have four process spare inlet nozzles located $\sim 16.5$-ft from the tank knuckle bottom, $\sim 0.6$ - $\mathrm{ft}$ above the cascade overflow line and 1.4-ft below the top of the steel liner. The steel bottom of the C Farm tanks intersects the sidewall on a 4-ft radius (BPF-73550, Drawings D-2 and D-3, Specification for Construction of Composite Storage Tanks (B, C, T, and U Tank Farms)).

Figure 3-1 shows the detail of the knuckle liner to the grout, and three-ply asphaltic waterproof membranes between the bottom and sidewall intersection (BPF-73550, Sheet D5). 
Figure 3-1. B C T U Tank Farm Knuckle Configuration with Three-ply Waterproofing (BPF-73550, Sheet B5)

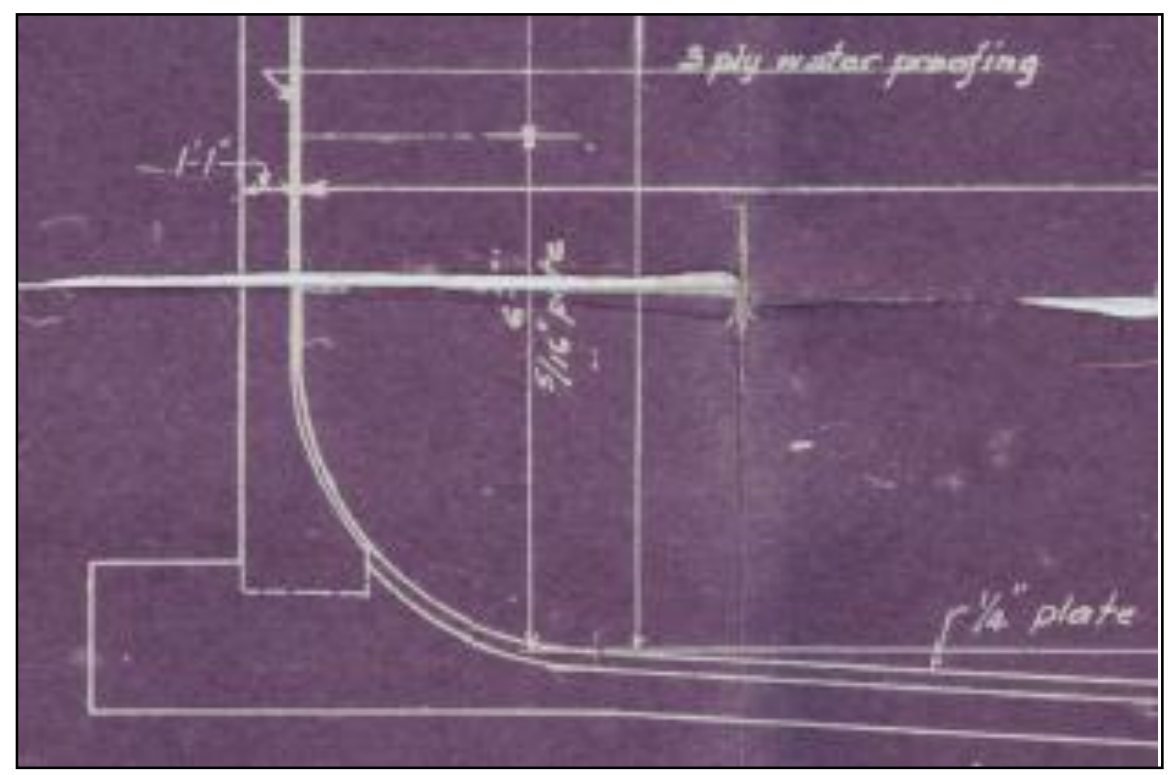

\section{Spare Inlet Line Penetrations}

The C Farm tanks were equipped with four inlet penetrations when constructed and are located at approximately the 198-in manual outlet pipe centerline tape liquid level (equivalent to a waste volume of $\sim 557 \mathrm{kgal}$ ). Tank $\mathrm{C}-101$ has two inlet lines connected to these nozzles (see Section 4.1) and tank C-105 has one inlet line connected, Line V103 (see Section 5.1). The penetrations that were not connected to a pipeline are referred to as "capped spare nozzles" as a loose-fitting metal cap was placed over the 4-in Schedule 80 pipe stub. The metal cap was not welded in place but provided with a gasket (RPP-ASMT-46452, Rev. 0, Tank 241-C-105 Leak Assessment Completion Report). It is known from the tank BX-102 waste loss event investigation (HW20742, Loss of Depleted Metal Waste Supernate to Soil, page 5) that some of the spare nozzles on SSTs are poorly sealed. If the tanks were overfilled above these capped spare nozzles, then it is likely that waste escaped through these inlet penetrations.

\section{Cascade Inlet or Outlet Lines}

The C Farm tanks are arranged in three-tank cascades, with each downstream tank in the cascade set 12-in lower than the previous tank to facilitate gravity flow from one tank to the next, to the next. The cascade outlet pipe centerline at the tank liner is at an equivalent waste volume of $\sim 545 \mathrm{kgal}$ (193.5-in manual tape liquid level). The cascade inlet pipe centerline at the tank liner is at an equivalent waste volume of $\sim 553 \mathrm{kgal}$ (196.5-in manual tape liquid level) (BPF-73550 Sheet D-5; BPF-73550 Sheet D-7, Miscellaneous Details for 75 Foot Tanks; LET-082172, H.N. Raymond to C.J. Francis, August 21, 1972, Maximum Operating Levels and Cascade Levels in 200-West Area Tank Farms). During construction the space between the 4-in Schedule 80 pipe sleeve and the 3-in Schedule 80 cascade line was tightly packed with asbestos wick to prevent waste from leaking through the gap if the tank was overfilled (RPP-ASMT-46452, Rev. 0). The 
cascade line penetration is 43-in long and it seems unlikely the entire annulus space between the cascade sleeve and pipe would have been packed with asbestos. If the tank was overfilled above these cascade penetrations, then it is likely there would be leakage if they were submerged (RPPASMT-46452, Rev. 0).

\subsubsection{Tank Construction Conditions}

The C Farm construction temperatures were examined to determine if the tank liner fabrication occurred at or below the metal ductile-to-brittle temperature transition. The photograph in Figure 3-2 shows the C Farm under construction on June 22, 1944.

Figure 3-2. C Farm Construction Photograph (P3490 N1585559)

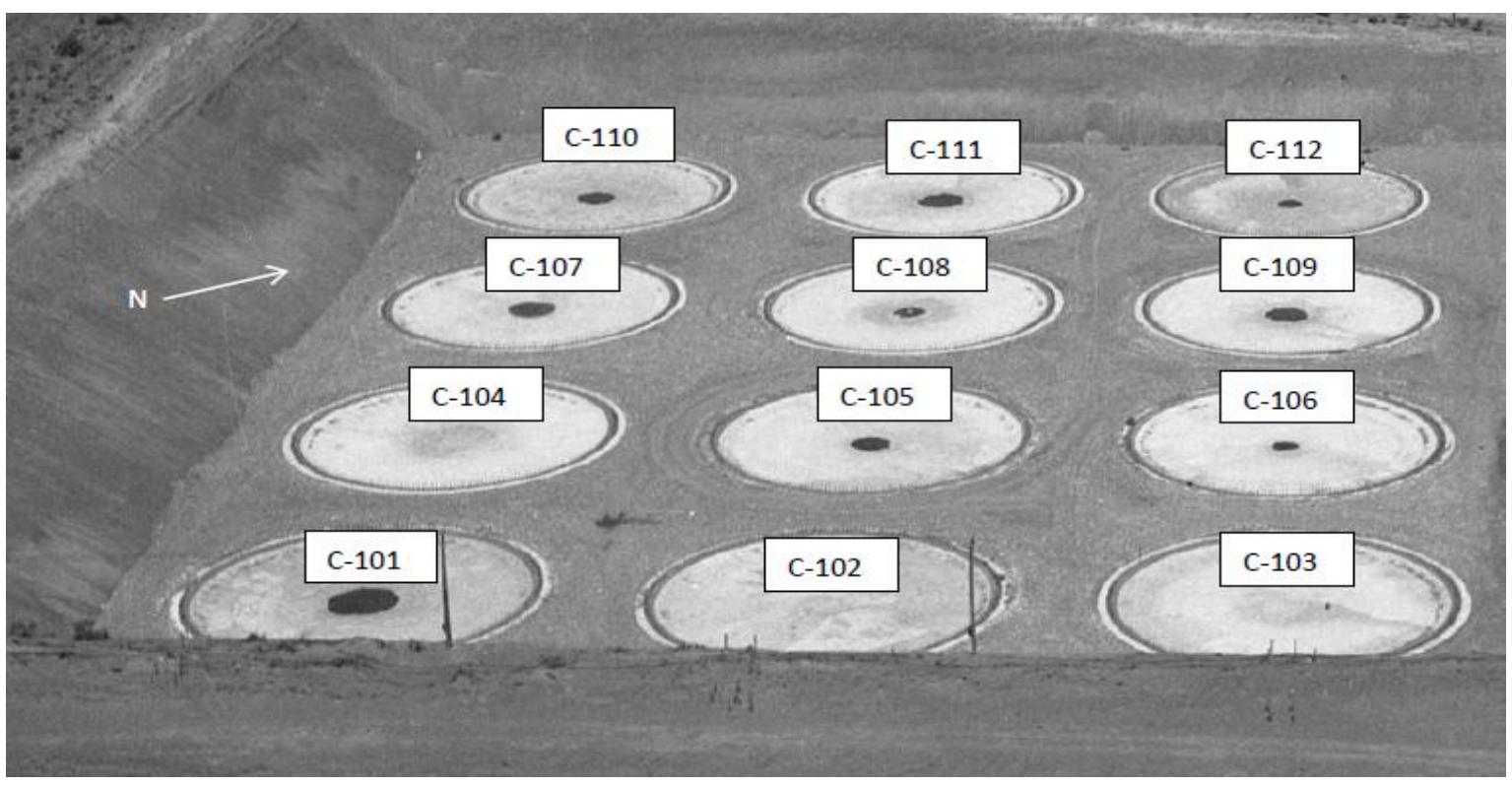

The metallurgical factors that limited carbon steel's ability to resist impact at low temperature were perhaps not well understood when C Farm was constructed and were not specified for the 0.25-in thick ASTM A7-39, Standard Specifications for Steel for Bridges and Buildings, mild carbon steel liner at the time. Current standards for construction of pressure vessels (ASME Boiler \& Pressure Vessel Code (B\&PVC), Section VIII, Rules for Construction of Pressure Vessels) provide requirements for vessels constructed of carbon and low alloy steels with respect to minimum design metal temperatures. That standard does not identify ASTM A7-39 as a material type but it does identify ASTM A283, Standard Specification for Low and Intermediate Tensile Strength Carbon Steel Plates. Early versions of ASTM A283 were similar to A7-39 because they identified the same chemical composition requirements as ASTM A7-39, and ASTM A283 steel plate and ASTM A7-39 steel plate had the same required tensile strength range, minimum yield point, and bending properties. Current B\&PVC Section VIII requirements specify, for ASTM A283 material of nominal thickness $\leq 10-\mathrm{mm}(0.394-\mathrm{in})$, a minimum design metal temperature of $18^{\circ} \mathrm{F}$. For the purposes of this report, it will be assumed that the $18^{\circ} \mathrm{F}$ design temperature is applicable to the fabrication of ASTM A7-39 carbon steel. 
Boxes from the list of Vendor Information Reports for the C Farm were searched for any Chemical and Physical Test Reports for the tank steel plates used in the farm but none were found. No other information for C Farm was found during the search.

A review of toughness and the ductile-to-brittle transition temperature for carbon steels (designated as "impact transition temperature") in Mark's Standard Handbook for Mechanical Engineers, Tenth Edition, indicates that carbon content can have a significant effect. Decreased carbon content not only raises the propagation energy needed for crack growth but also lowers the temperature for transition from ductile-to-brittle behavior (reference Fig 6.2.11 in Marks), suggesting that the B\&PVC Section III low temperature service limit may be lower than what could be expected for steel of the vintage used in C Farm construction. The concentrations of carbon and trace impurities and their effect on this property are not specifically known, and low temperature impact resistance could only be determined reliably by impact testing of actual tank specimens.

Below the transition temperature, the metal loses its ability to absorb forces such as induced loads, or the impact of falling objects without fracturing. In this circumstance it is possible for micro-fissures or hairline cracks to be created. Later, when the metal is subjected to high stress, it might be possible for the cracks to propagate through the metal, or possibly subject the weakened areas to increased corrosion.

Any low temperatures experienced during construction at or less than the $18^{\circ} \mathrm{F}$ allowable temperature where impact loading (e.g. a dropped tool or piece of equipment from scaffolding) had the potential for creating micro-fissures may have triggered fissures in the steel liner (see Sections 4.3.2 and 5.3.2).

Design, fabrication, and erection of the tank steel lining were required to be in accordance with current "Standard Specifications for Elevated Steel Water Tanks, Standpipes and Reservoirs" as promulgated by the "American Water Works Association" (BPF 73550). Welding and inspection requirements were to conform to the American Welding Society's "Code for Arc and Gas Welding in Building Construction", Section 4.

The possible variability of liner steel from either different runs from the same supplier, or because of multiple suppliers could affect the resistance to low temperatures.

\subsection{IN-TANK DATA FOR LEAKING C FARM TANKS}

The general information in this section is further developed and applied to the leaking tanks in Sections 4.4 and 5.4 for tanks C-101 and C-105, respectively, to understand implications of the conditions that could affect liner leaks and identify possible liner leak locations.

\subsubsection{Liquid Level}

The following is an excerpt from RPP-ENV-39658 (Hanford SX-Farm Leak Assessments Report): 
"Originally liquid levels were measured using pneumatic dip tubes (HW-10475-C, Hanford Technical Manual Section C, page 908). This practice was later replaced and a manual tape with a conductivity electrode was used to detect the liquid surface (H-2-2257, Conductor Reel for Liquid Level Measurement). The biggest limitations of the manual tape measurements were failures of the electrodes, solids forming on the electrode and measurement precision. The statistical accuracy of the manual tape and electrode measurement technique was 0.75 in. ( 2,060 gal), as determined in July 1955 (HW-51026, Leak Detection - Underground Storage Tanks, page 4). Later, liquid-level determinations were automated in many of the SSTs to provide more accurate and reliable measurements".

It was stated in RPP-RPT-43704 (Hanford BY-Farm Leak Assessments Report) that the accuracy for the manual tape can vary from 0.25 -in to 2 -in for different tanks depending on surface conditions (liquid/solids), boiling, air lift circulator (ALC) operation, and conductivity.

The in-tank repeatability limits for FIC liquid level gauges are \pm 0.25-in (Letter 72730-80-097, "Review of Classification of Six Hanford Single-Shell "Questionable Integrity (QI)" Tanks").

Transfer discrepancies of greater than 1.5-in (4125 gal) measured at the first hour and every two hours thereafter with an FIC, manual tape, or flowmeter required an orderly and immediate shutdown, investigation, and notification. The 1.5-in discrepancy requirement was a specification limit in ARH-1601, Section D, Specifications and Standards for the Operation of Radioactive Waste Tank Farms and Associated Facilities.

Liquid level measured by manual tape (MT) is calculated for B, C, T, and U Farm tanks with the formula: volume $=($ MT Reading X 2750 gal/in $)+12,500$ gal $($ LET-082172, H.N. Raymond to C.J. Francis, August 21, 1972, Maximum Operating Levels and Cascade Levels in 200-West area Tank Farms). Even though the letter title indicates only west area, the above formula for the B, $\mathrm{C}, \mathrm{T}$, and $\mathrm{U}$ Farm tanks is found on the last page of the letter. The formula was confirmed to have been used as late as 1980 in RHO-CD-896, page 76, for the then current tank T-111 volume (488,000 gallons) and MT reading (173 inches) which verified use of the formula. All half yearly and quarterly report ending volumes in this document were calculated with this formula. Original MT readings and the MT readings in PCSACS are all measured from the lower knuckle of the above tanks which is 12-in above the bottom inside center of the tanks. The ENRAF liquid level readings in PCSACS have been converted to read from the bottom inside center of the tank. Therefore, for the same reported liquid level the ENRAF reading is 12-in greater than the MT reading.

\subsubsection{Temperature}

Early temperature data is not available for the C Farm tanks until the 1970s. Available waste temperatures starting in the 1970s can be found in WHC-SD-WM-ER-313, Rev. 0, Supporting Document for the Historical Tank Content Estimate for C Tank Farm, and in PCSACS. Tanks C-101 and C-105 both received MW and TBP wastes. Historical documents in the following two paragraphs can be used to infer probable tank temperatures for the storage of these wastes in tanks C-101 and C-105 (see Sections 4.22 and 5.22 for individual tank waste temperature). 
Document HW-20742, Loss of Depleted Metal Waste Supernate to Soil, reports MW was cascaded into a 241-BX Farm series of tanks with temperatures recorded in the first tank of $\sim 180^{\circ} \mathrm{F}$, which contains the bulk of the uranium and fission products, and $\sim 70^{\circ} \mathrm{F}$ in the last tank of the cascade.

Tri-Butyl Phosphate (TBP) wastes were concentrated and cooled to $\sim 180^{\circ} \mathrm{F}$ within the $221-\mathrm{U}$ plant. The wastes were steam sparged in the WR Vault pump tanks prior to shipping to 200 East Area and were estimated to be $110-180^{\circ} \mathrm{F}$ after pumping to the storage tanks (HW-19140, Uranium Recovery Technical Manual, p. 1209). The first tank in the cascade such as tank $\mathrm{C}-101$ was likely near $180^{\circ} \mathrm{F}$ whereas the second and third tanks in the cascade were much less.

The C Farm tank construction specifications indicated the temperature of the liquid contents would be (up to) $220^{\circ} \mathrm{F}$ (HW-1946, Specifications for Composite Storage Tanks - Buildings \#241 at Hanford Engineering Works). The condensers on the B, C, T, and U Farm tanks were reported to be adequate for the waste temperatures and vapor loads for the original operations at approximately $180^{\circ} \mathrm{F}$ for supernatant and sludge (WHC-MR-0132, A History of the 200 Area Tank Farms).

The earliest operation limitations found for C Farm are addressed in ARH-951, Limitations for Use of Underground Waste Tanks. The ARH-951 document was issued December 18, 1969 and indicated that tank temperatures should be held below $230^{\circ} \mathrm{F}$ with a $5^{\circ} \mathrm{F}$ per day rise for liquid temperatures below $180^{\circ} \mathrm{F}$ and a $3^{\circ} \mathrm{F}$ per day rise for liquid temperatures above $180^{\circ} \mathrm{F}$ during waste addition to the tank.

\subsubsection{Liner Observations}

A bulge in a tank liner may result in the direct failure of the liner or cause enough stress or thinning on the steel liner plates and welds that they become more susceptible to the effects of corrosion. Experience indicates that bulging tends to be a dynamic phenomenon, and it is possible that a tank with no measured bulge at one point in time may actually have had a displaced liner that was not detected at another time.

No reports indicating liner bulging were found for any of the C Farm tanks.

\subsubsection{Chemistry}

The types of corrosion that may occur in the Hanford Site SSTs include uniform corrosion, stress corrosion cracking (SCC), pitting, crevice, and liquid-air interface corrosion which were identified in HNF-3018, Single-Shell Tank Sluicing History and Failure Frequency.

Uniform corrosion rates for SSTs are reported to be generally less than 1 mil/year (HNF-3018) for the SSTs. Carbon steel exposed to alkaline solutions has a low general corrosion rate (PNL5488, Prediction Equations for Corrosion Rates of A-537 and A-516 Steels in Double Shell Flurry). However, the presence of the nitrate ion may induce various forms of localized attack (i.e., SCC, pitting, etc.). 


\section{Nitrate Ion-Induced Stress Corrosion Cracking}

Stress corrosion cracking is the growth of cracks in a corrosive environment. It can lead to unexpected sudden failure of normally ductile metals subjected to a tensile stress, especially at elevated temperatures. Stress corrosion cracking is highly chemically specific in that certain alloys are likely to undergo SCC only when exposed to a small number of chemical environments. The chemical environment that causes SCC for a given alloy is often one which is only mildly corrosive to the metal otherwise.

Nitrate ion-induced SCC is the predominant threat to the integrity of the steel liners in the SSTs and DSTs at the Hanford Site and many investigations have been performed to establish the parameters under which the tanks can be protected from this threat. This work, together with the efforts of many others, led to the adoption of the waste chemistry control limits for SCC prevention in 1983 (OSD-T-151-00017, Operating Specifications for the Aging Waste Operations in Tank Farms 241-AY and 241-AZ).

The factors governing the rates of nitrate ion-induced SCC cracking by Hanford Site DST wastes were recently reviewed (RPP-RPT-47337, Specifications for the Minimization of the Stress Corrosion Cracking Threat in Double-Shell Tank Wastes). In brief, the test results led to the conclusion that the rates of nitrate ion-induced SCC depended on the properties of the steel, the applied potential versus the open circuit potential (OCP), the temperature and the concentrations of aggressive substances such as nitrate ion, and the potential inhibitors such as hydroxide and nitrite ion.

The technical work has shown that SCC is promoted by high temperatures, high nitrate ion concentrations, low hydroxide ion concentrations, low nitrite ion concentrations, and low nitrite ion/nitrate ion concentration ratios. Tanks with maximum temperatures less than $122^{\circ} \mathrm{F}$ would not be expected to experience significant SCC damage regardless of waste types (HNF-3018, Rev. 0). Tanks with the maximum temperatures above $122^{\circ} \mathrm{F}$ and a ratio of nitrate concentration to the sum of nitrite and hydroxide concentrations greater than 2.5 would be expected to suffer SCC-related damage (HNF-3018, Rev. 0). The concentration of nitrate and temperature are parameters that have the most effect on SCC. However, the $\mathrm{pH}$ (hydroxide) and nitrite can inhibit SCC. The current double-shell tank operating specifications for chemistry are reported in OSD-T-151-00007, Rev. 10, Operating Specifications for the Double-Shell Storage Tanks. While the chemistry specifications stated in this document were prepared for the DSTs, corrosion mechanisms and corrosion protection mechanisms applicable to DST primary tank metal liners they are equally applicable to the older SST metal liners.

\section{Localized Corrosion: Crevice, Pitting, and Liquid-Air Interface Corrosion}

Crevice corrosion can occur in regions where a small volume of solution cannot readily mix with the bulk solution such as under deposits, between metal flanges, and other confined areas. Once initiated, crevice corrosion proceeds by the same mechanism as pitting corrosion (RPP-RPT33306, IQRPE Integrity Assessment Report for the 242-A Evaporator Tank System). 
Pitting corrosion is the localized corrosion of a metal surface confined to a point or small area that takes the form of cavities. Pitting corrosion in dilute solutions $\left(\mathrm{NO}_{3}{ }^{-}<1 \mathrm{M}\right)$ of waste has been studied at the Savannah River Site (SRS). Pitting has been determined to not be a problem at hydroxide concentrations greater than $1 \mathrm{M}$ for any of the diluted waste solutions tested (WSRC-TR-90-512, Effect of Temperature on the Nitrite Requirement to Inhibit Washed Sludge, Oblath and Congdon 1987, Inhibiting Localized Corrosion during Storage of Dilute Waste). Nitrate ion was determined to be the usual controlling aggressive species when its concentrations ranged between $0.01 \mathrm{M}$ and 1M (WSRC-TR-90-512). The presence of hydroxide ion and nitrite ion has shown to inhibit pitting corrosion due to the aggressive nitrate ion. This work led to the conservative recommendation that the concentration of nitrite ion be greater than $0.033 \mathrm{M}$ for the avoidance of pitting in dilute solutions of nitrate ion at $\mathrm{pH} 10$ and $40^{\circ} \mathrm{C}\left(104^{\circ} \mathrm{F}\right)$ (RPP-ASMT-53793, Rev. 0).

The chemical compositions required for prevention of pitting corrosion can also be applied as limits for prevention of liquid-air interface corrosion at the surface of the supernatant.

Crevice, pitting, and liquid-air interface corrosion are types of localized corrosion possible in the SSTs; however, historically SCC is the more predominant type of corrosion of concern.

\section{Historical Corrosion Control}

The earliest chemical specifications for SSTs addressing $\mathrm{pH}$, nitrite, nitrate, and hydroxide are listed in Table 3-1 (ARH-1601, Section D, Specifications and Standards for the Operation of Radioactive Waste Tank Farms and Associated Facilities, 1973).

Table 3-1. ARH-1601 Specifications 1973

\begin{tabular}{|c|c|}
\hline \multicolumn{2}{|c|}{ Waste Tank Farms and Associated Facilities Specifications } \\
\hline Variable & Specification \\
\hline $\mathrm{pH}$ & Minimum 8.0 \\
\hline $\mathrm{NO}_{2}^{-}$ & $500 \mathrm{ppm}$ \\
\hline $\mathrm{NO}_{3}^{-}$ & $<6 \mathrm{M}$ \\
\hline $\mathrm{OH}^{-}$ & $<7 \mathrm{M}$ \\
\hline
\end{tabular}

There was no similar specification found that addressed all of these parameters during the operation of C Farm prior to 1973. However, if the ARH-601 specifications were in effect during $\mathrm{C}$ Farm waste storage, the storage of undesirable concentrations of $\mathrm{NO}_{2}{ }^{-}, \mathrm{NO}_{3}{ }^{-}$, and $\mathrm{OH}^{-}$ would result in vulnerability to SCC and/or localized corrosion.

Historical waste sample data as well as temperatures are typically not available for the SSTs and none were recovered for tanks $\mathrm{C}-101$ and $\mathrm{C}-105$. Thus, the concentrations of $\mathrm{NO}_{2}{ }^{-}, \mathrm{NO}_{3}{ }^{-}$, and $\mathrm{OH}^{-}$listed in Sections 4.4.4 and 5.4.4 are typical concentrations that were reported for the waste types listed that could be based on limited data and/or were values obtained from process flowsheets. Therefore, waste chemistry conditions are speculative when sample and temperature data is unavailable especially when multiple waste types are present in the tank. 
RPP-RPT-54914, Rev. 0

\subsubsection{Photographs}

Available photographs of the C Farm leaking tanks C-101 and tank C-105 were reviewed. Photographs were reviewed to identify beachlines possibly indicating previous operations of overfilling the tank, damaged equipment, possible liner bulges, and any other anomalies that could be indicative of a tank liner leak, and/or possible leak location. See Sections 4.4.5 and 5.4.5 for details for tanks C-101 and C-105, respectively. The photographs do not indicate a liner bulge for tanks $\mathrm{C}-101$ and $\mathrm{C}-105$.

\subsection{EX-TANK DATA FOR LEAKING C FARM TANKS}

The general information in this section is further developed and applied to the leaking tanks in Sections 4.4 and 5.4 for tanks C-101 and C-105, respectively, to understand implications of the conditions that could affect liner leaks and identify possible liner leak locations.

\subsubsection{Laterals}

Leak detection laterals were installed approximately 10-ft underneath some of the tanks containing self-boiling waste in 241-A and 241-SX Farms. Lateral leak detection systems were not installed under the C Farm tanks. Each lateral is a 3-in pneumatic stainless steel tubing enclosed in 4-in carbon steel pipe. Probes were driven to the end of the lateral with compressed air then slowly withdrawn to gather a radiation profile below the bottom of the tank.

\subsubsection{Drywells}

Six drywells are located around tank C-101 and 15 drywells are located around tank C-105. All of the radiation readings in drywells are assumed to be maximum or peak readings unless otherwise noted. Drywells were drilled vertically from the surface and drywell coordinates and detailed drywell information, e.g., pipe dimensions and configuration, for tanks C-101 and C-105 are addressed in references sited in the individual tank segments. Drywells will not be useful to detect releases that enter the soil from the tank unless the volume released is sufficiently large to facilitate lateral transport to a drywell typically to within $\sim 1-\mathrm{ft}$ of the drywell. The vertical height of a tank liner leak may not be directly related to the point of detection in the drywell. This is especially true for small leaks that may flow downward some distance before encountering a drywell.

The "00" series drywells (drywell 30-00-06, C Farm) were installed shortly after tank construction, usually around the periphery of the farm and most extend to 150-ft below grade surface (BGS). Others with tank numbers embedded in the drywell number (30-01-01, tank C101) were constructed later, sometimes after tank operations had ceased and generally to 100-ft BGS, with a few deeper than 100-ft BGS. The usual number of drywells surrounding a tank is one to four. If there are more, then there likely was some concern regarding a release which was being investigated. The second number corresponds to the clocked position of the drywell with respect to due north.

Four gamma ray probe types were used to monitor gamma in drywells to detect leaks (RPP8321, Analysis and Summary Report of Historical Dry Well Gamma Logs for the 241-C Tank 
Farm 200 East Area). The most widely used probe was the unshielded gross gamma sodiumiodide $(\mathrm{NaI})$ probe (or probe 04 ; the shielded $\mathrm{NaI}$ probe was referred to as probe 14). The NaI probe (04) is very sensitive and able to record gamma ray activity from 30 counts per second (cps) up to about $40,000 \mathrm{cps}(15 \mathrm{mR} / \mathrm{hr})$ before the data becomes unreliable (RHO-RE-EV-4, Supporting Information for the Scientific Basis for Establishing Dry Well Monitoring

Frequencies. The next most commonly used probe was the Red-GM (or probe 02) which is less sensitive but can reliably record gross gamma at much higher levels of activity (up to $\sim 500 \mathrm{R} / \mathrm{hr}$ ). Operation of these and other probes are discussed in HNF-3136, Analysis Techniques and Monitoring Results, 241-SX Drywell Surveillance Logs. A scintillation probe (SP) was also used to measure low levels of radiation in the drywells. Leak location identification is primarily focused on the first indication of a leak and is therefore typically concerned with the lower levels of gross gamma detection and initial migration.

Drywell sections (see Sections 4.5.1 and 5.5.1) contain gross gamma figures taken from RPP8321 showing continuing or new contamination in the drywells based on BGS depth from 1975 to 1994. Some of these gross gamma figures show anomalous data that appear to be unexplained detections that do not reflect radioactivity in the soil. In 1998, a baseline characterization of the gamma-ray-emitting radionuclides distributed in the vadose zone sediments beneath and around C Farm was performed using spectral gamma logs (SGLS) and documented in GJPO-HAN-18, Vadose Zone Characterization Project at the Hanford Tank Farms C Tank Farm Report. The gross gamma figure detection sensitivity is higher than SGLS $(\sim 10 \mathrm{pCi} / \mathrm{g}$ versus $\sim 0.1 \mathrm{pCi} / \mathrm{g}$ equivalent Cs-137). Therefore, radioactivity $\leq 10 \mathrm{pCi} / \mathrm{g}$ does not appear on the gross gamma figures (GJPO-HAN-18). Co-60 has a higher detection threshold; therefore, SGLS will detect Co-60 at much lower levels than what is detected by gross gamma logging. SGLS logging can confirm both Cs-137 and/or Co-60 radioactivity which can assist in the leak location analysis, and the SGLS data is weighted more heavily on interpreting drywells. The criteria for drywell monitoring are defined in RHO-ST-34 (A Scientific Basis for Establishing Drywell-Monitoring Frequencies) with the monitoring frequency found in SD-WM-TI-356 (Waste Storage Tank Status and Leak Detection Criteria).

All of the radiation readings in drywells are assumed to be maximum or peak readings unless otherwise noted and are from the Red-GM probe unless otherwise indicated. The individual tank segments report the available drywell data in the drywell section and in some cases the more recent direct push drywells installed to locate detailed soil radioactivity. The drywell summary section provides the analyses of the associated drywells and any direct pushes with the tank that is of concern.

\subsection{LINER LEAK LOCATIONS}

Drywell radioactivity when first detected can indicate a radial or depth location of a tank leak, migration of the tank leak, or the possible migration of an adjacent tank leak. The radial drywell radioactivity is also dependent on any possible flow paths from the actual tank liner leak location to the drywell itself as well as the waste viscosity and distance to the drywell. Drywells can also be an indication of the tank liner sidewall leak depending on the vertical location but needs to be analyzed relative to non-tank liner leaks associated with pipe lines or other sources. 
Liquid level decreases can be used for sidewall as well as bottom liner leaks but need to be analyzed in relationship with the vertical level of the tank drywell radioactivity, evaporation and drywell contamination from pipe line leaks and other non-tank sources.

A liner leak may have penetrated the waterproof membrane at any location and followed concrete cracks or construction joints to a different location including the top of the tank footing. Therefore, the point of waste egress from the tank liner may not be the point of entry of the leaking waste to the soil. Later indications of radioactivity in the drywells with improved detector capabilities could indicate additional leakage but the location of the leak could not be pinpointed without some additional information.

The lack of radioactivity above background in a drywell indicates that if there was a liner leak it either occurred at another location, the leak flow was insufficient to be detected with the probes used in the drywell, or was not able to be detected with the gamma probe. When there is no radioactivity detected in a drywell or no recoverable data for a drywell it is not included as part of the leak location analysis.

\subsection{POSSIBLE LINER LEAK CAUSE(S)}

Analysis of the C Farm commonalities which centered on tank design/construction, in-tank data, and ex-tank data indicates that there was essentially one condition, chemistry-corrosion, that was the most likely to have contributed to a possible tank failed liner. Waste chemistry was not controlled to the degree necessary to minimize corrosion when tanks C-101 and C-105 were suspected of leaking. There appears to be very little contribution from tank design (no inherent flaws have been documented in the literature reviewed) and construction temperatures. Waste thermal conditions for tank C-101 were within control parameters, however, tank C-105 required water cooling of sludges as temperature may have ranged above 180 possibly up to boiling temperatueres. Some or all of the factors can act serially or together to contribute to tank liner failure. The following sections provide a tank C-101 and tank C-105 review of these conditions as they relate to liner leak causes.

Other general tank construction factors such as the quality of materials and fabrication could also contribute to tank liner failure. Because no evidence has been found to substantiate quality defects, these are not included as a leak cause. 


\subsection{TANK 241-C-101 SEGMENT}

\section{TABLE OF CONTENTS}

4.1 Tank C-101 Background History .................................................................... 4-4

4.2 Tank C-101 Operations Summary ................................................................. 4-5

4.3 Tank Design/Construction ........................................................................... 4-9

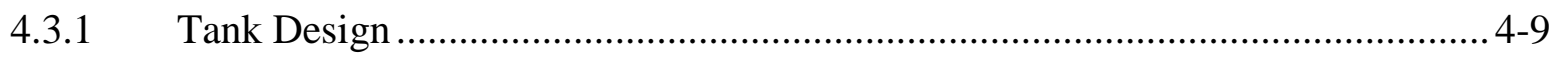

4.3.2 Tank Construction Conditions ............................................................... 4-9

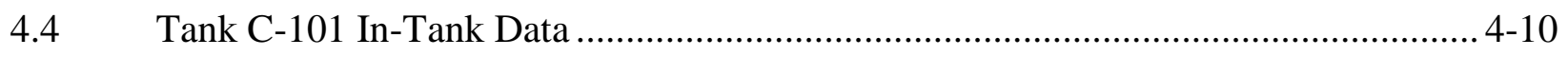

4.4.1 Liquid Level............................................................................... 4-10

Temperature .................................................................................... 4-12

Liner Observations ............................................................................... 4-12

Chemistry-Corrosion............................................................................. 4-12

4.4.5 Photographs.................................................................................... 4-13

4.5 Tank C-101 Ex-Tank Data ............................................................................ 4-15

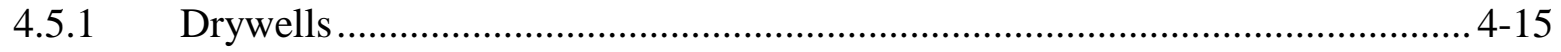

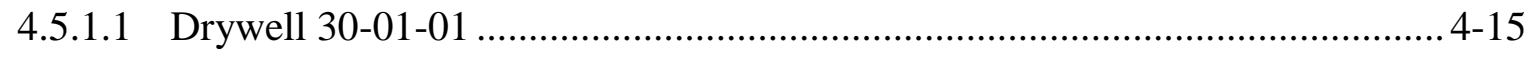

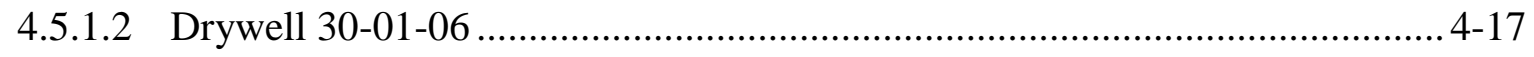

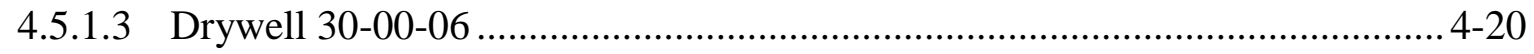

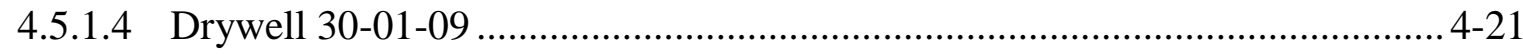

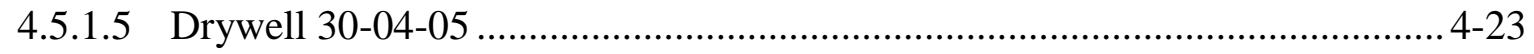

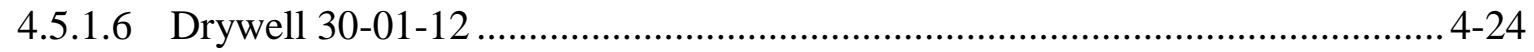

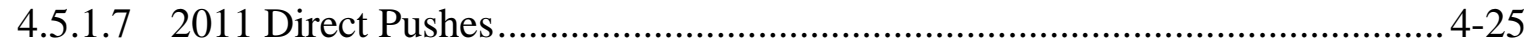

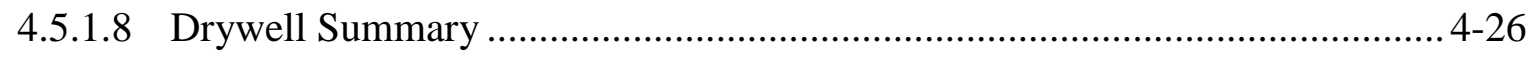

4.6 Possible Tank C-101 Liner Leak Location(s) .................................................... 4-26

4.6.1 Leak Detected in April 1970 ................................................................... 4-27

4.6.2 Leak Detected in August 1971 .................................................................. 4-29

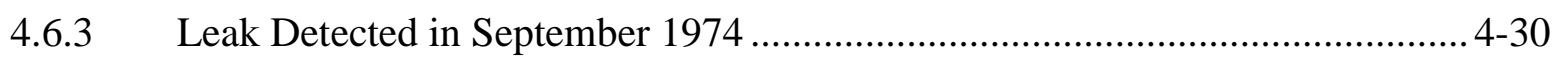

4.6.4 Leak Location Summary ..................................................................... 4-31

4.7 Possible Tank C-101 Liner Leak Cause(s).................................................... 4-33

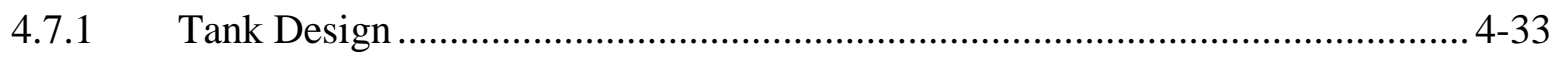




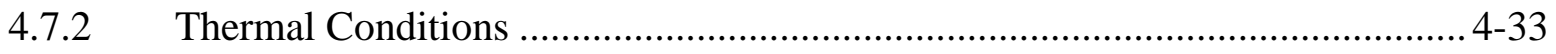

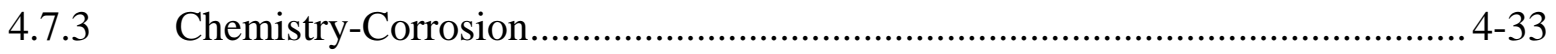

4.7.4 Liner Observations ............................................................................ 4-33

4.7.5 Tank Construction Temperature ……………............................................ 4-33

4.8 Tank C-101 Conclusions ................................................................................... 4-34

\section{Appendices}

Appendix A1 Tank C-101 Gross Gamma Drywell Data ..........................................................A1-1

Appendix B1 Detailed Tank C-101 Liquid Level Analysis..................................................... B1-1

\section{LIST OF FIGURES}

Figure 4-1. Tank C-101 Associated Drywells ......................................................................... 4-4

Figure 4-2. Operational Leak History of Tank C-101 …....................................................... 4-8

Figure 4-3. B C T U Tank Farm Knuckle Configuration with Three-Ply Waterproofing........... 4-9

Figure 4-4. Tank C-101 End of Quarter Surface Level ........................................................... 4-10

Figure 4-5. Tank C-101 Liquid Level 1964 - 2010................................................................. 4-11

Figure 4-6. Tank C-101 Photograph February 13, 1970 (700695-13 CN) ............................... 4-14

Figure 4-7. Tank C-101 Photograph February 13, 1970 (700695-4 CN) ................................. 4-15

Figure 4-8. Drywell 30-01-01 Historical Gross Gamma Logging .......................................... 4-16

Figure 4-9. Tank C-101 Drywell 30-01-01 (RPP-8321).......................................................... 4-17

Figure 4-10. Drywell 30-01-06 Historical Gross Gamma Logging April 7, 1970 ................... 4-18

Figure 4-11. Tank C-101 Drywell 30-01-06 (RPP-8321)…………………………….......... 4-19

Figure 4-12. Tank C-101 Drywell 30-00-06 (RPP-8321)_...................................................... 4-20

Figure 4-13. Drywell 30-01-09 Historical Gross Gamma Logging April 7, 1970 ................... 4-21

Figure 4-14. Tank C-101 Drywell 30-01-09 (RPP-8321) ................................................. 4-22

Figure 4-15. Tank C-101 Drywell 30-04-05 (RPP-8321).................................................... 4-23 
Figure 4-16. Tank C-101 Drywell 30-01-12 (RPP-8321) ................................................... 4-24

Figure 4-17. Tank C-101 Direct Push Location.................................................................... 4-25

Figure 4-18. Tank C-101 Possible Leak Location (April 1970) ............................................... 4-28

Figure 4-19. Tank C-101 Possible Leak Location (August 1971) .............................................. 4-29

Figure 4-20. Tank C-101 Possible Leak Location (September 1974) ...................................... 4-30

Figure 4-21. Tank C-101 Possible Radial Leak Locations .......................................................... 4-32

Figure B1-1. Tank C-101 LL 1964 - 2010 …………………………………………….... B1-2

Figure B1-2. Tank C-101 LL 6/30/1965 - 9/30/1969 ……………………………………... B1-4

Figure B1-3. Tank C-101 LL June 30, 1966 to December 15, 1969 ...................................... B1-5

Figure B1-4. Tank C-101 1969 Projected LL Decrease .......................................................... B1-6

Figure B1-5. Tank C-101 LL September 30, 1969 to August 15, 1974 .................................. B1-8

Figure B1-6. Tank C-101 Photograph February 13, 1970 (700695-20) .................................. B1-9

Figure B1-7. Tank C-101 LL 8/15/1973 - 6/30/1980 ……………………………………... B1-10

Figure B1-8. Tank C-101 Surface at the Thermocouple and Manual Tape Location ........... B1-11

Figure B1-9. Tank C-101 PCSACS LL January 5, 1981 - August 25, 2010 ........................ B1-12

Figure B1-10. Tanks C-101, C-102, and C-103 Condensers May 14, 1982......................... B1-13

Figure B1-11. 241-C Farm Atmospheric Condensers, Fan and Stack Removed April 18, 1983 ................................................................................ B1-13

\section{LIST OF TABLES}

Table 4-1. Tri-Butyl Phosphate Supernatant and 242-B Evaporator Bottoms ............................ 4-6

Table 4-2. Tank C-101 Waste Storage Chronology.............................................................. 4-13

Table 4-3. Waste Chemistries for Waste Types Stored in Tank C-101 ................................... 4-13

Table A1-1. Tank C-101 Drywell Radioactivity (K counts per minute) (September 1959 through March 1987) ..................................................................................... A1-2 


\subsection{TANK C-101 BACKGROUND HISTORY}

This section provides information on the historical waste loss event associated with Single-Shell Tank (SST) 241-C-101 (C-101). There are six drywells located around tank C-101 with specified distances from the drywell to the tank footing shown in Figure 4-1: 30-00-06, installed December 1944; 30-01-01 and 30-01-12, installed in March 1970; 30-01-06, installed in January 1970; 30-01-09, installed in April 1970 and 30-04-05, installed in July 1974.

Figure 4-1. Tank C-101 Associated Drywells

Tank inner ring is steel liner; outer ring is outer edge of tank footing

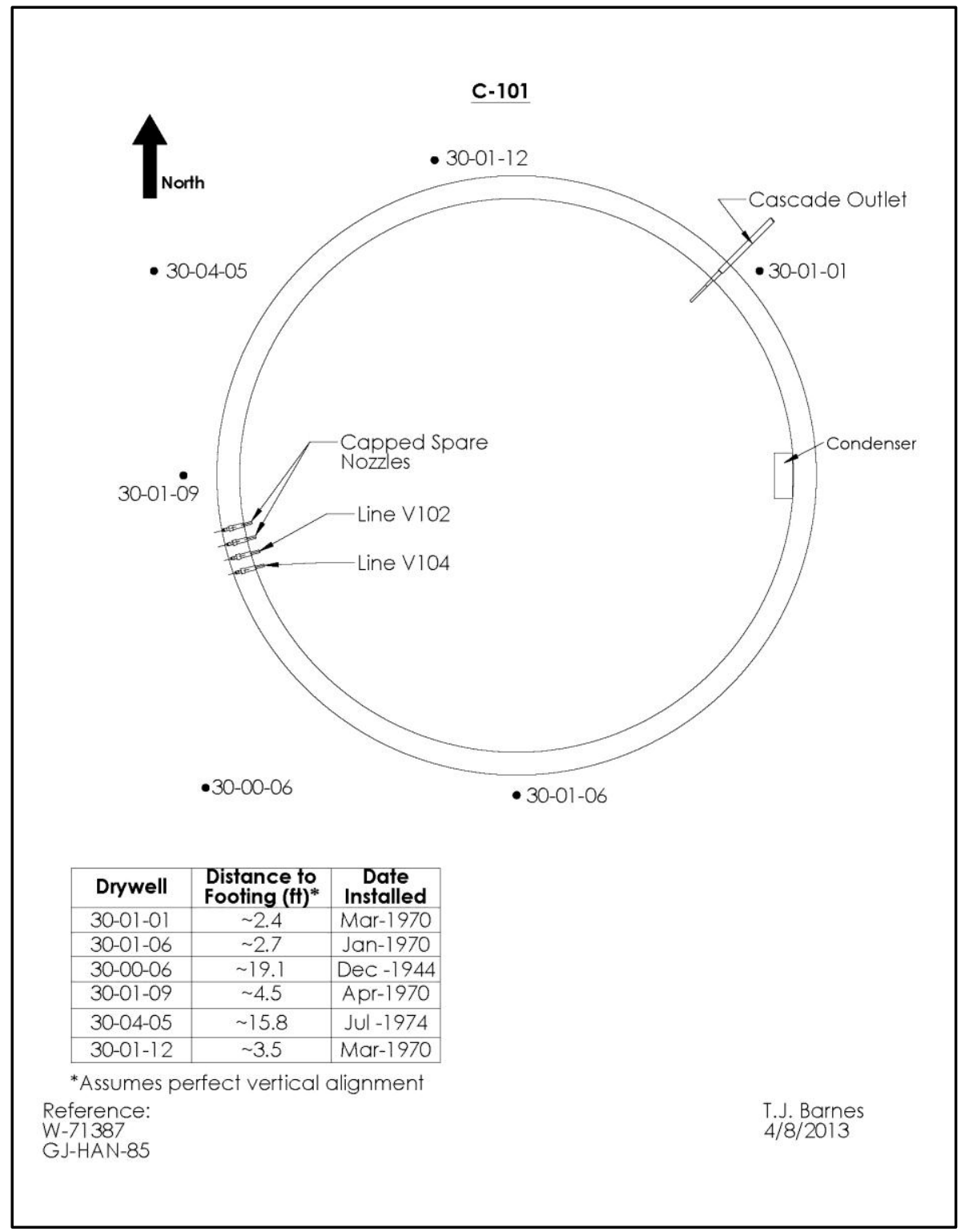


The bottom of the tank footing is $~ 37$-ft 6-in Below Grade Surface (BGS) with 5.6-ft soil cover over the dome (WHC-SD-WM-TI-665, Soil Load above Hanford Waste Storage Tanks; BPF73550, Specifications for Construction of Composite Storage Tanks Blg. No. 241, Hanford Engineer Works, Project 9536). The cascade outlet pipe centerline at the tank liner is $\sim 20$-ft 8-in BGS which corresponds to waste volume of $\sim 545 \mathrm{kgal}$ (193.5-in manual tape liquid level). The capped spare nozzles centerline at the tank liner is $~ 20$-ft 4-in BGS which corresponds to a waste volume of $\sim 557 \mathrm{kgal}$ (198-in manual tape liquid level) (BPF-73550 Sheet D-5; BPF-73550 Sheet D-7, Miscellaneous Details for 75 Foot Tanks; LET-082172, H.N. Raymond to C.J. Francis, August 21, 1972, Maximum Operating Levels and Cascade Levels in 200-West Area Tank Farms).

\subsection{TANK C-101 OPERATIONS SUMMARY}

Tank C-101 began receiving metal waste (MW) from the 221-B Plant bismuth phosphate process in March 1946. By May 1946, the tank was declared full and waste began cascading waste to tank C-102. Tank C-102 was declared full with MW in August 1946 and MW supernatant cascaded to tank C-103. The cascade of tanks C-101, C-102 and C-103 was declared full by October 1946. Metal waste from the 221-B Plant was then diverted to other SSTs for storage.

The MW sat undisturbed in tank C-101 until the fourth quarter of 1952. A uranium precipitate formed in the MW, settling to the bottom of the tank as a sludge layer. The MW supernatant and sludge were removed from tank C-101 from the fourth quarter 1952 through May 14, 1953. Metal waste removal from tanks C-102 and C-103 was also conducted during this period. These tanks were inspected and deemed fit for re-use to store additional waste.

Tank C-101 began receiving Tri-Butyl Phosphate (TBP) waste intermittently from 221-U Plant beginning on May 15, 1953 (HW-28377, page 4). During August 1953, tank C-101 was filled with TBP waste and supernatant was cascaded to tank C-102. The TBP supernatant waste was pumped from tank C-101 to tank C-103 in September 1953. The reason why waste was not cascaded from tank C-101 to $\mathrm{C}-102$ and then to $\mathrm{C}-103$ is not provided in the monthly tank farm reports. The cascade overflow line from tank C-101 to tank C-102 may have been plugged during this time. The cascade overflow line to tank C-102 is first noted in the tank farm monthly reports as being partially plugged in June 1954 (HW-32389, page 4). All three tanks were noted as being filled with TBP waste in October 1953.

In December 1955, TBP supernatant waste was transferred from tank C-101 to the 244-CR Vault for precipitation of cesium and strontium using ferrocyanide (so-called In Farm scavenging) ${ }^{1}$. The TBP waste along with the ferrocyanide $(\mathrm{FeCN})$ precipitate was discharged to tank $\mathrm{C}-109$ for settling of the precipitate, with the supernatant then transferred to 216-BC-4 crib (HW-44784,

\footnotetext{
${ }^{1}$ Tank C-101 was sometimes referred to as tank 101-CR when used in conjunction with the 244-CR Vault for In Farm scavenging operations.
} 
page 20). Tank C-101 was then refilled (total waste volume $485 \mathrm{kgal}$ ) with TBP supernatant from tank C-104 in January 1956.

In September and October 1956, $354 \mathrm{kgal}$ of TBP supernatant waste were transferred from tank C-101 to 244-CR Vault for In Farm scavenging, leaving approximately $131 \mathrm{kgal}$ of waste in the tank. The TBP waste along with the FeCN precipitate was discharged to tank C-112 for settling of the precipitate, with the supernatant then transferred to 216-BC-10 crib (HW-48518, page 19). The volume of waste in tank C-101 was later revised to $98 \mathrm{kgal}$ in February 1957 as a result of a new waste surface electrode measurement.

Tank C-101 continued to be used through 1957 as the feed tank to the In Farm scavenging process conducted in the 244-CR Vault. Tank C-101 received TBP supernatant and 242-B Evaporator bottoms wastes from the tanks listed in Table 4-1. The scavenged waste was transferred to tanks C-108, C-109, C-111 and C-112 for settling of the FeCN precipitate before discharge to the 216-BC trenches.

\begin{tabular}{|c|c|c|c|}
\hline \multicolumn{4}{|c|}{$\begin{array}{l}\text { Table 4-1. Tri-Butyl Phosphate Supernatant and 242-B Evaporator Bottoms } \\
\text { Transferred to Tank C-101 }\end{array}$} \\
\hline Tank & Volume, gallons & Date & Reference \\
\hline 241-BY-101 & 455,000 & June 1957 & HW-51348, page 5 \\
\hline 241-BY-102 & 717,000 & June 1957 & HW-51348, page 5 \\
\hline 241-BY-101 & 227,000 & July 1957 & HW-83906-C RD, pages 64 \\
\hline 241-BY-103 & 551,000 & July 1957 & HW-83906-C RD, pages 64 \\
\hline 241-BY-103 & 162,000 & August 1957 & HW-83906-C RD, pages 72 \\
\hline 241-B-101 & 228,000 & August 1957 & HW-83906-C RD, pages 72 \\
\hline 241-B-102 & 424,000 & August 1957 & HW-83906-C RD, pages 72 \\
\hline 241-B-103 & 297,000 & August 1957 & HW-83906-C RD, pages 72 \\
\hline 241-B-107 & 265,000 & September 1957 & HW-83906-C RD, page 80 \\
\hline 241-B-108 & 399,000 & September 1957 & HW-83906-C RD, page 80 \\
\hline 241-B-109 & 403,000 & September 1957 & HW-83906-C RD, page 80 \\
\hline 241-B-106 & 379,000 & October 1957 & HW-83906-C RD, page 88 \\
\hline 241-B-112 & 495,000 & October 1957 & HW-83906-C RD, page 88 \\
\hline $241-B X-110$ & 88,000 & October 1957 & HW-83906-C RD, page 88 \\
\hline $241-B X-110$ & 113,000 & November 1957 & HW-83906-C RD, page 97 \\
\hline 241-BX-111 & 511,000 & November 1957 & HW-83906-C RD, page 97 \\
\hline 241-BX-108 & 484,000 & November 1957 & HW-83906-C RD, page 97 \\
\hline 241-BX-109 & 243,000 & December 1957 & HW-83906-C RD, page 104 \\
\hline
\end{tabular}

Tank C-101 contained approximately $98 \mathrm{kgal}$ of sludge and approximately $27 \mathrm{kgal}$ of supernatant following the completion of the In Farm scavenging process in January 1958. The tank did not receive any waste again until 1960. Beginning in December 1960 (HW-68292, page 4) and intermittently until 1962, tank C-101 received plutonium-uranium extraction (PUREX) process cladding removal waste (CWP) from the PUREX Plant. During 1962, tank C-101 was filled and further additions of CWP cascaded to tanks C-102 and C-103. The CWP was subsequently transferred from tanks C-102 and C-103 to tanks BX-101 and BX-102. Tank C101 stopped receiving CWP in June 1962 (HW-74647). The CWP was transferred to tank B-107 in the fourth quarter of 1963, leaving 94 kgal of sludge in tank C-101 (HW-80379). In the 
fourth quarter of 1963, tank C-101 received $276 \mathrm{kgal}$ of PUREX high-level waste (PUREX HLW) from tank A-102 in order to prepare tank A-102 for use in sluicing sludge from tank A103 (HW-80379, page 4).

Tank C-101 received $172 \mathrm{kgal}$ of PUREX HLW from tank A-103 in the first quarter of 1964 (HW-83308, page 4), bringing the total waste volume to $546 \mathrm{kgal}$, which is above the cascade overflow level. In the second quarter of 1965, tank C-101 was reported to have received $28 \mathrm{kgal}$ of waste from 244-CR Vault and the tank volume was reported as $574 \mathrm{kgal}$ (corresponding to a waste height of 204-inmanual tape reading) (RL-SEP-659, page 4), which exceeds the cascade overflow level (191.5-in manual tape liquid level). However, there is no record that waste cascaded from tank C-101 into tank C-102 during this timeframe (see Section 4.4.1). The spare inlet nozzles on the SSTs are at a height of 198-in (manual tape liquid level) and it is known from the tank BX-102 waste loss event investigation (HW-20742, page 5) that some of the spare nozzles on SSTs are poorly sealed. It is possible that some PUREX HLW was lost during this time through the spare inlet nozzles to the soil nearby tank C-101.

No additional transfers of waste into or waste removals from tank C-101 are reported until the fourth quarter of 1969. During the period between January 1965 and September 1969, the waste volume decreased in tank C-101 from $574 \mathrm{kgal}$ to $536 \mathrm{kgal}$, a decrease of $38 \mathrm{kgal}$. No records could be located indicating the basis for the decrease in tank C-101 liquid level. Tank C-101 was declared of questionable integrity in 1969 based on a 23 month liquid level decrease from 194.5in to 190.5-in. In the fourth quarter of 1969, approximately $404 \mathrm{kgal}$ from tank C-101 was transferred to tank C-105 and then to 221-B Plant for processing through the cesium ion exchange system. The pumpable liquid was removed from tank C-101 in 1969, leaving approximately $47 \mathrm{kgal}$ of supernatant ( 17-in) covering $87 \mathrm{kgal}(\sim 40.7$-in) of sludge. The liquid level continued to decrease from 1970 through 1974.

Tank C-101 was removed from service in the first quarter of 1976 and primary stabilized 1979. It was categorized as a confirmed leaker in 1980 with an approximate leak volume of $20 \mathrm{kgal}$. Intrusion prevention was completed in December 1982, and the tank was categorized interimstabilized in November 1983 (HNF-EP-0182, Rev. 219). Document RPP-ENV-33418, Rev. 2A, determined tank C-101 began leaking in January 1968 through December 1969 with the leak volume of 17 to $24 \mathrm{kgal}$.

As of June 30, 2006, tank C-101 contains $88 \mathrm{kgal}$ of sludge (HNF-EP-0182, Rev. 219). The estimated volume is equivalent to 39.5-in referenced to the tank center bottom. For inventory estimates, the waste are designated as CWP and TBP sludge with $4 \mathrm{kgal}$ of drainable interstitial liquid and no pumpable liquid (TWINS).

The operational history of tank C-101 leak related details including temperature and liquid level is charted in Figure 4-2. 


\section{Figure 4-2. Operational Leak History of Tank C-101}

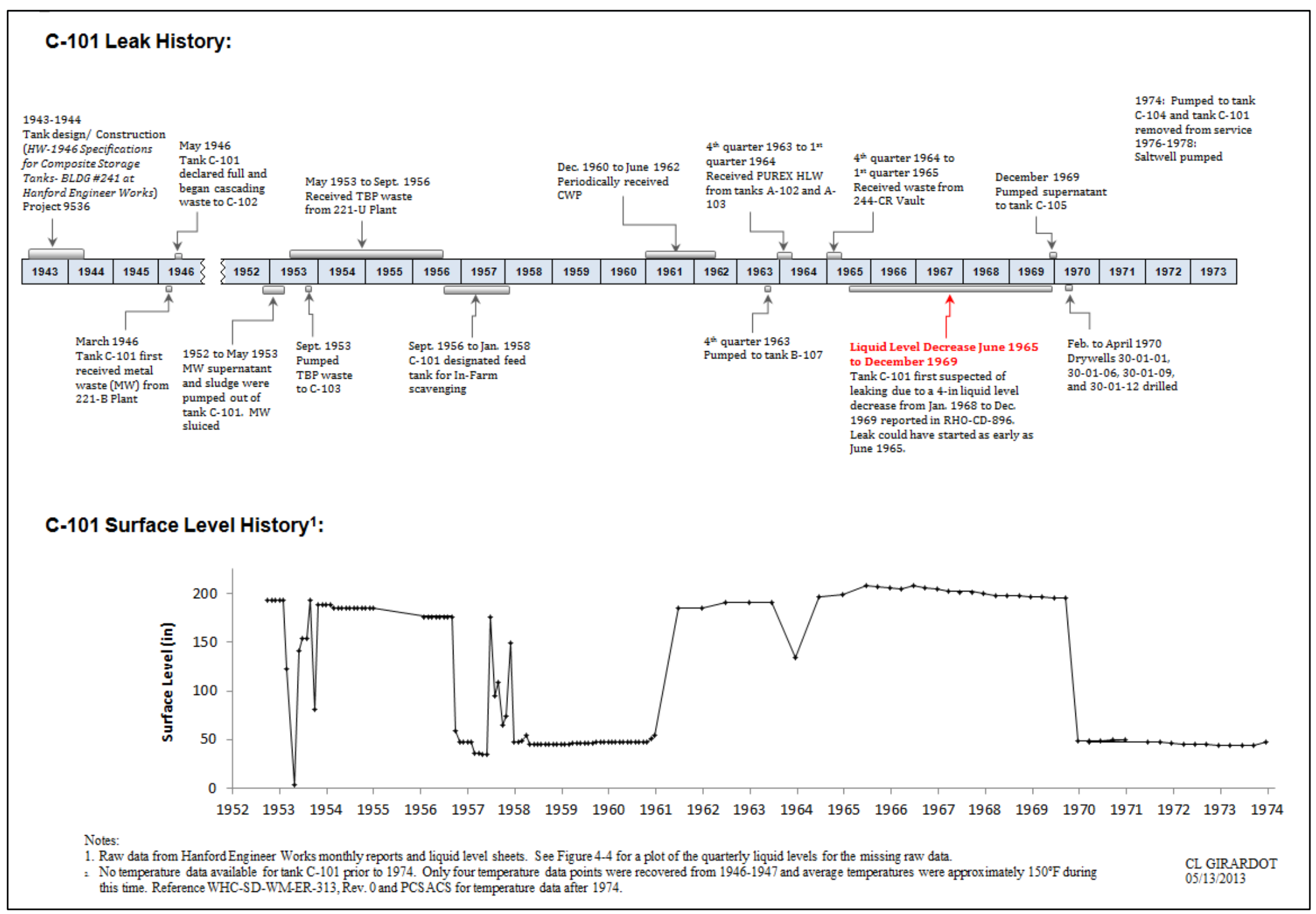




\subsection{TANK DESIGN/CONSTRUCTION}

\subsubsection{Tank Design}

The steel bottoms of the $\mathrm{C}$ Farm tanks intersect the sidewall on a 4-ft radius knuckle transition (BPF-73550, Drawings D-2 and D-3). Figure 4-3 shows the detail of the rounded knuckle transition, the three-ply asphaltic membrane waterproofing between the liner and the concrete, a notched footing construction joint, and the concrete shell. These features are common to all $\mathrm{C}$ Farm tanks (see Section 3.1.1).

\section{Figure 4-3. B C T U Tank Farm Knuckle Configuration with Three-Ply Waterproofing BPF-73550, Sheet B5}

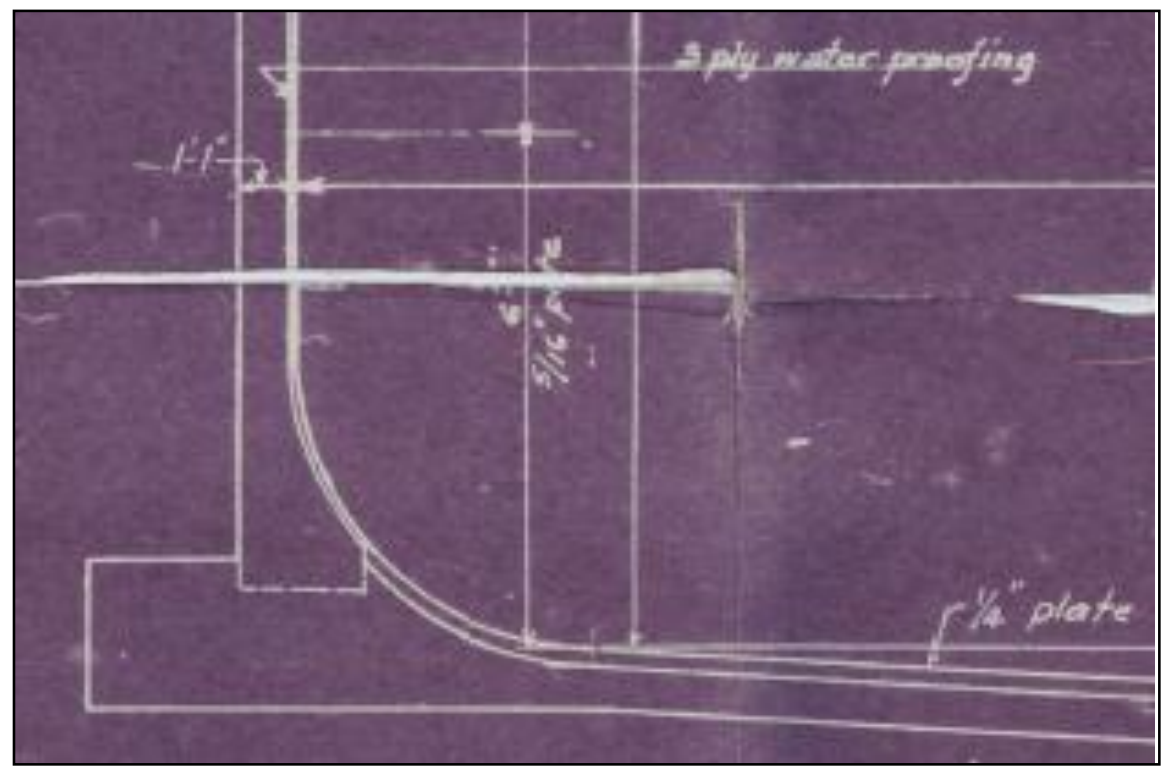

\subsubsection{Tank Construction Conditions}

The C Farm tanks were constructed between August 1944 and December 1944. Temperatures are not available for 1944 between May 18 and December 1 as a note was found that the weather station was shutdown. There is a possibility that the $400-\mathrm{ft}$ tower was under construction during that time which is right next to the weather station building. The building may have been closed during that time for safety reasons (Meteorological and Climatological Services [MCS]).

As described in Section 3.1.2, cold weather affects the ductile-to-brittle steel transition temperature, with $18^{\circ} \mathrm{F}$ being the assumed unrestricted low temperature construction limitation for the carbon steel liner, which could result in a fracture upon impact. However, the time of year during construction of the $\mathrm{C}$ Farm tanks would indicate that there would probably not be temperatures low enough to affect the ductile-to-brittle transition temperature.

Design, fabrication, and erection of the tank steel lining were required to be in accordance with current "Standards Specifications for Elevated Steel Water Tanks, Standpipes and Reservoirs" as promulgated by the "American Water Works Association" (BPF 73550). Welding requirements 
RPP-RPT-54914, Rev. 0

were required to conform to the American Welding Society's "Code for Arc and Gas Welding in Building Construction", Section 4.

\subsection{TANK C-101 IN-TANK DATA}

\subsubsection{Liquid Level}

The liquid level plot in Figure 4-4 indicates the transfer activity into and out of tank C-101. The liquid levels are end of quarter levels so this figure may not reflect all transfers into and out of the tank that occurred during the operational history. See Figure 4-2 for historical monthly liquid level readings.

Figure 4-4. Tank C-101 End of Quarter Surface Level

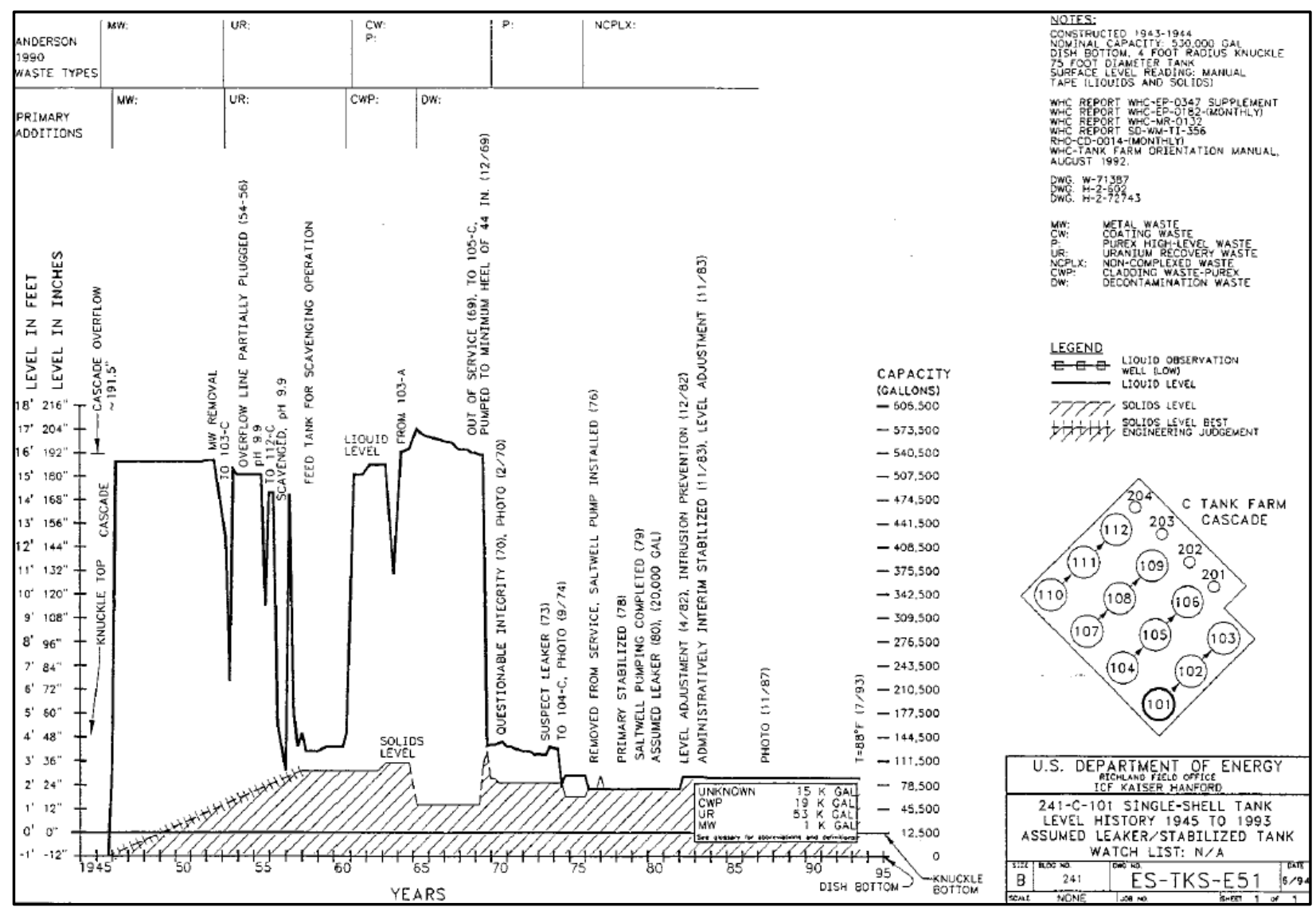

WHC-SD-WM-ER-349, Rev. 0, August 3, 1994, Historical Tank Content Estimate for the Northeast Quadrant of the Hanford 200 East Area

Tank C-101 was first suspected of leaking based on a liquid level decrease of 4 -in between approximately January 1968 and December 1969 and the supernatant was pumped to tank C-105 (RHO-CD-896, January 1980, Review of Classification of Nine Hanford Single-Shell “Questionable Integrity” Tanks). The RHO-CD-896 document review of the 1968-1969 liquid level decrease, radioactivity detected in drywells drilled in 1970, and potential liquid level decrease January 1970 to October 1973 recommended tank C-101 be reclassified as a Confirmed Leaker. The reclassification was based primarily on the 1968-1969 liquid level decrease with 
some possible corroborating drywell radioactivity. The tank was pumped to tank C-104 in 1974, removed from service, and salt well pumped 1976-1978.

Document RHO-CD-896 reported an unexplained liquid level decrease between January 1968 and December 1969. However, it appears the liquid level decrease started as early as June 1965 when the liquid level was above the spare inlet lines (see Figure 4-5). A detailed analysis of four tank C-101 liquid level periods from 1964 into 2010 is contained in 01.

Figure 4-5. Tank C-101 Liquid Level 1964 - 2010

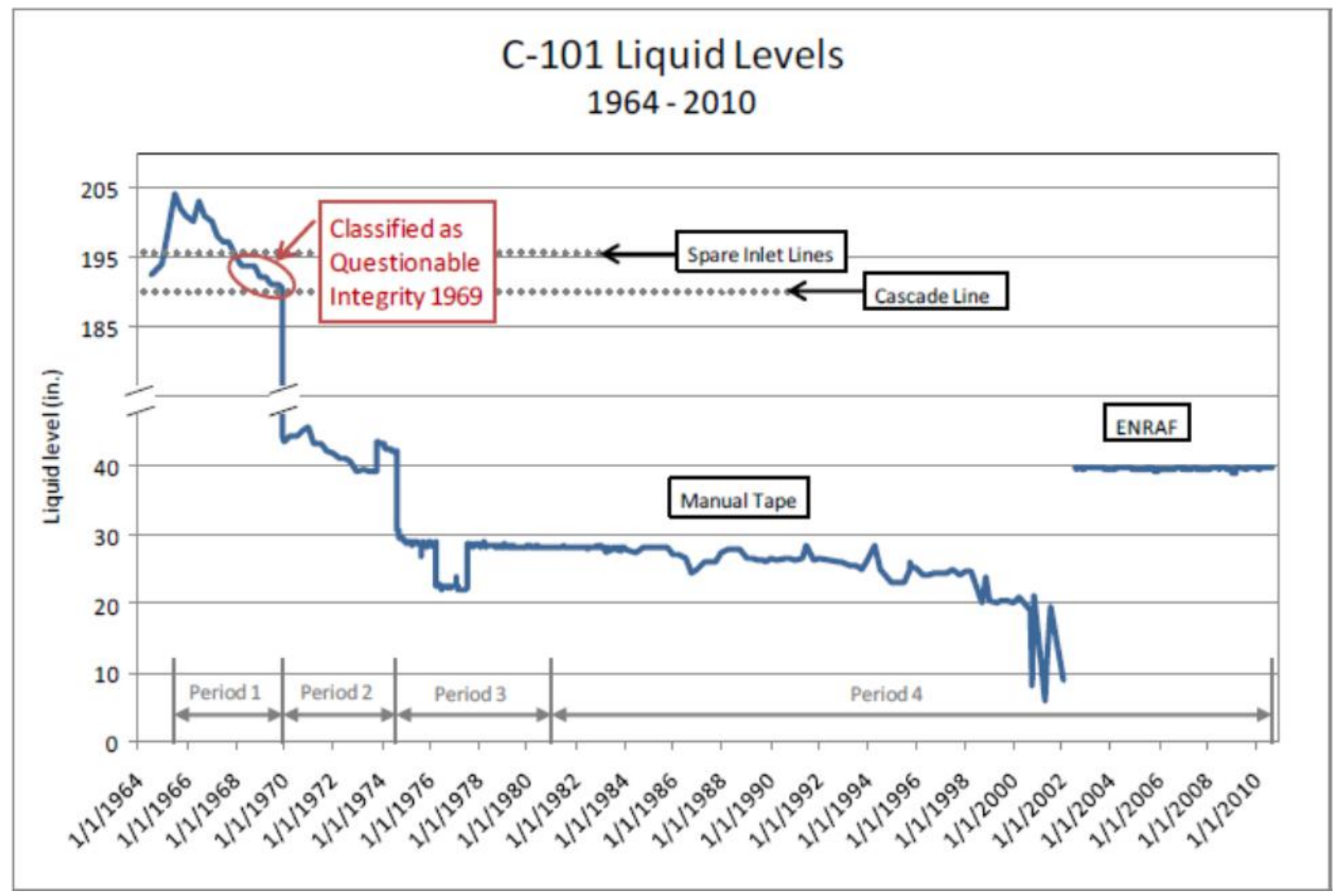

The detailed liquid level analysis indicated the possibility that the inlet line and cascade line packing could have leaked. The cascade line which had a partial plugging problem earlier could have been seeping to tank C-102 which was obscured by multiple transfers into and out of tank C-102. In addition, the liquid level could have been decreasing with vapor that was not condensed in the atmospheric condenser or that could have leaked past the condenser gasket. Also, there is a possibility of a tank leak. It was noted the liquid level rate was decreasing as it approached the cascade line when the tank was pumped and little evidence exists for a liquid level decrease after pumping.

If the tank did leak, the leak would probably have occurred above a 40-in ENRAF measured liquid level as measured from the bottom of the tank center (28-in manual tape liquid level). The detailed liquid level analysis suggests that the tank liner may not have leaked. 


\subsubsection{Temperature}

No temperature data were recovered for tank C-101 from March 1946 when the tank was first put into service until June 1946. Only four temperature data points were recovered from June 1946 to November 1947 for tank C-101 until 1974. On June 23, 1946, the waste temperature of tank C-101 was reported at $125.6^{\circ} \mathrm{F}$ and $138.2^{\circ} \mathrm{F}$ on November $30,1946, \mathrm{HW}-14946$, A Survey of Corrosion Data and Construction Details, 200 Area Waste Storage Tanks. The next two data points were reported on June 2, 1947 and November 30,1947 at $168.8^{\circ} \mathrm{F}$ and $167^{\circ} \mathrm{F}$, respectively. During this time, only metal waste was being stored in the tank from 221-B Plant.

Tank C-101 received TBP waste from 221-U Plant from May 1953 to September 1956. TBP wastes were concentrated and cooled to $\sim 180^{\circ} \mathrm{F}$ within the plant and were estimated to be 110 $180^{\circ} \mathrm{F}$ after routing to the storage tanks.

Tank C-101 received CWP from December 1960 to June 1962. Waste type CWP would have a low fission product content and resulting heat load resulting in a temperature probably less than $100^{\circ} \mathrm{F}$.

Condensers on the B, C, T, and U Farm tanks were reported to be adequate for the waste temperatures and vapor loads for the original operations at approximately $180^{\circ} \mathrm{F}$ for supernatant and sludge (WHC-MR-0132, A History of the 200 Area Tank Farms).

Waste temperatures from 1974 to 1992 can be found in WHC-SD-WM-ER-313, Rev. 0, Supporting Document for the Historical Tank Content Estimate for C Tank Farm, and temperatures ranged from approximately $70^{\circ} \mathrm{F}$ to $110^{\circ} \mathrm{F}$ during this time. Waste temperatures from 1992 to present are available in PCSACS and temperatures were reported to be less than $100^{\circ} \mathrm{F}$ (see PCSACS).

\subsubsection{Liner Observations}

No liner observations relating to a tank C-101 leak have been found.

\subsubsection{Chemistry-Corrosion}

Tank C-101 began receiving waste in March 1946 and received various waste types throughout operation as shown in Table 4-2. The typical concentrations for nitrite, nitrate, and hydroxide for these waste types are shown in Table 4-3. Nitrite and hydroxide are known as nitrate induced SCC inhibitors. One key characteristic for inhibiting SCC is to maintain a high nitrite concentration to nitrate concentration ratio (see Section 3.2.4). 
RPP-RPT-54914, Rev. 0

Table 4-2. Tank C-101 Waste Storage Chronology

\begin{tabular}{|c|c|c|}
\hline Date & Waste Type & Length of Storage \\
\hline March 1946 to May 1953 & MW & $\sim 7$ years \\
\hline May 1953 to September 1956 & TBP & $\sim 3$ years \\
\hline September 1956 to January 1958 & $\begin{array}{c}\text { TBP supernatant } \\
\text { 242-B Evaporator bottoms } \\
\text { FeCN }\end{array}$ & $\sim 3$ years \\
\hline December 1960 to $4^{\text {th }}$ quarter 1963 & CWP & $\sim 3$ years \\
\hline $4^{\text {th }}$ quarter 1963 to December 1969 & CWP/PUREX HLW & $\sim 6$ years \\
\hline
\end{tabular}

Table 4-3. Waste Chemistries for Waste Types Stored in Tank C-101

\begin{tabular}{|c|c|c|c|c|c|}
\hline Waste Type & {$\left[\mathrm{NO}_{3}{ }^{-}\right]^{1}$} & {$\left[\mathrm{NO}_{2}{ }^{-}\right]^{1}$} & {$\left[\mathrm{OH}^{-}\right]^{1}$} & \multicolumn{2}{|c|}{$\left[\mathrm{NO}_{\mathbf{3}}{ }^{-}\right] /\left(\left[\mathrm{OH}^{-}\right]+\left[\mathrm{NO}_{2}{ }^{-}\right]\right)$} \\
\hline MW & 0.59 & Not reported & 1.16 & $<0.5^{1}$ & $<2.5^{2}$ \\
\hline CWP & 0.6 & 0.9 & 1.0 & 0.32 & $<2.5^{2}$ \\
\hline TBP & 7.35 & Not reported & 0.09 & $>2.5^{3}$ & $<2.5^{2}$ \\
\hline
\end{tabular}

1. Reference WHC-EP-0449, 1991, The Sort on Radioactive Waste Type Model: A Method to Sort Single-Shell Tanks into Characteristic Groups.

2. OSD-T-151-00007 (2012) specification for waste chemistry

3. To be within the current DST specification limit, $\left[\mathrm{NO}_{2}^{-}\right]>2.8 \mathrm{M}$ which is unlikely

The first waste type stored in tank C-101 was MW from 221-B Plant and was stored in the tank for approximately seven years. Metal waste alone should not be a concern for either pitting or SCC under the tank C-101 conditions.

Tank C-101 stored TBP waste from 221-U Plant from May 1953 to September 1956. Samples of TBP waste indicate hydroxide concentrations below $0.1 \mathrm{M}$ and nitrate concentrations above $6 \mathrm{M}$. These conditions of the TBP waste would likely create an environment conducive to SCC. Tank C-101 also stored TBP supernatant and 242-B Evaporator bottoms wastes from September 1956 to 1961 as the tank was designated the feed tank to the In Farm scavenging process. The TBP supernatant and evaporator bottoms wastes could have set up a pitting situation along with SCC.

Tank C-101 stored CWP for approximately three years. Tank C-101 stored CWP and PUREX HLW for approximately six years and was present in the tank in 1965, when the tank could have started leaking based on liquid level decreases. PUREX coating waste and PUREX HLW should not be a concern for either pitting or SCC under the tank C-101 conditions.

\subsubsection{Photographs}

Tank C-101 photographs taken in February of 1970 show a beachline covering the cascade line penetration (see Figure 4-6). The February 1970 set of photographs was taken about 3 months after pumping the supernatant to tank C-105. 
RPP-RPT-54914, Rev. 0

Figure 4-6. Tank C-101 Photograph February 13, 1970 (700695-13 CN)

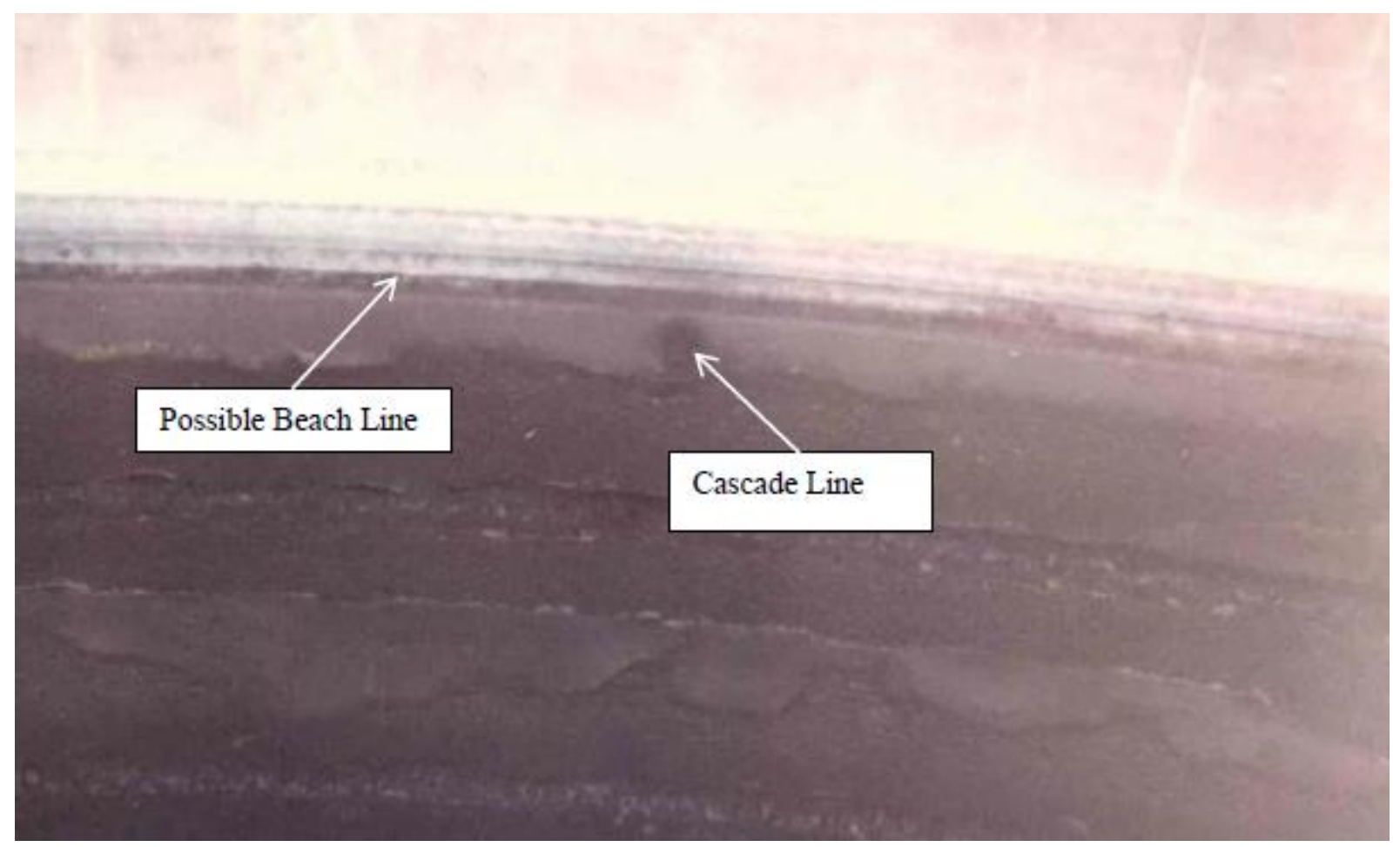

A photograph of the inlet lines (two active and two spares) also show a beach line which appears to be above the inlet lines (see Figure 4-7). The tank C-101 photographs do not show any evidence pointing to a tank leak. 


\section{Figure 4-7. Tank C-101 Photograph February 13, 1970 (700695-4 CN)}

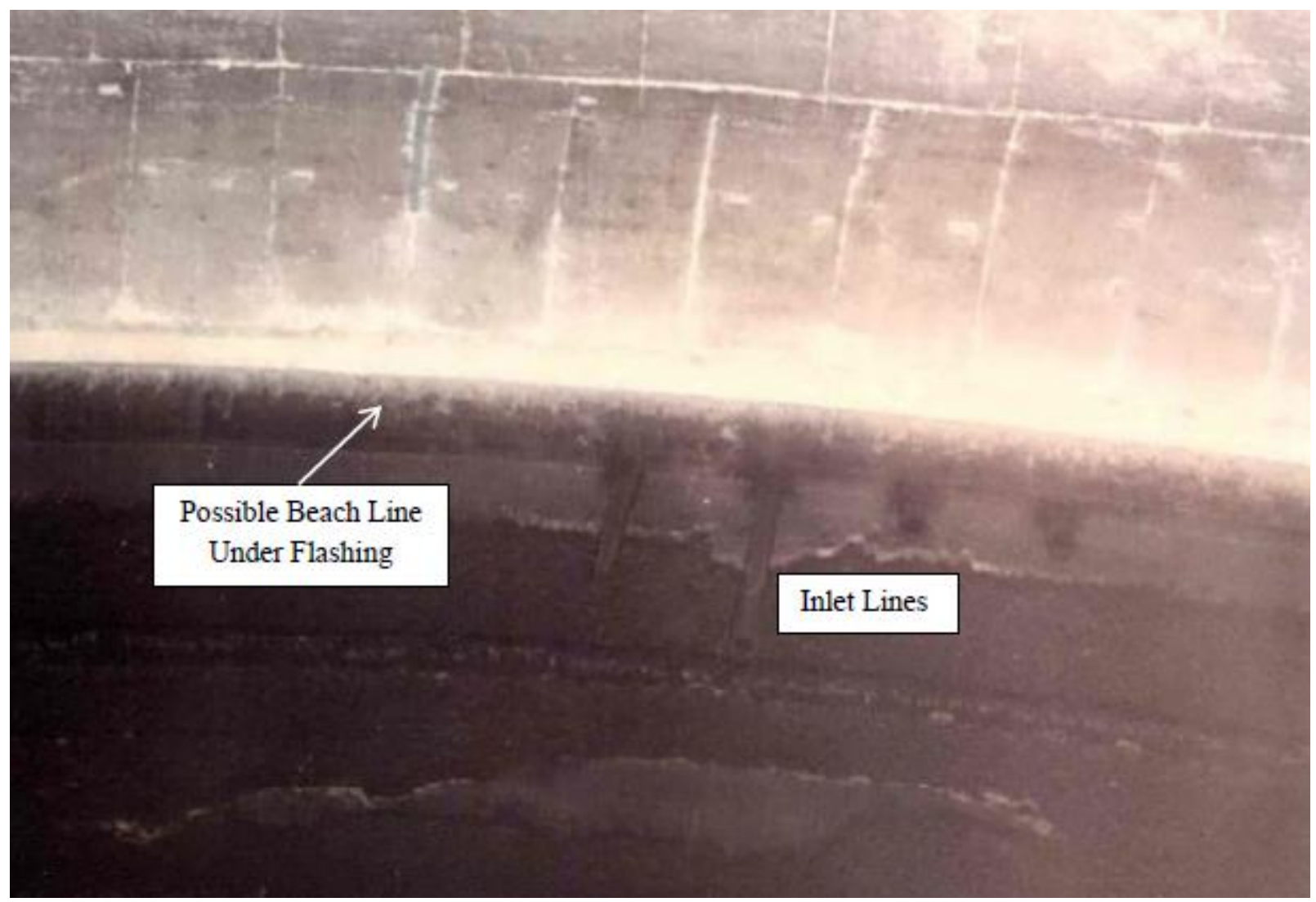

\subsection{TANK C-101 EX-TANK DATA}

\subsubsection{Drywells}

There are six drywells located around tank C-101: 30-00-06 installed in 1944, 30-01-01, 30-0106, 30-01-09, and 30-01-12 installed in 1970, and 30-04-05 installed in 1974. All of the radiation readings in drywells are assumed to be maximum or peak readings unless otherwise noted (see Section 3.3.2). The following subsections report the available drywell information and the drywell summary section provides the analyses of the associated drywells with tank C101.

\subsubsection{Drywell 30-01-01}

Drywell 30-01-01 was drilled in March 1970 with the first recoverable readings on May 11, 1970, January 7, 1971, and August 3, 1971 (see Figure 4-8). These plots indicate very little contamination in drywell 30-01-01 through January 7, 1971. On August 3, 1971 a peak at 27K cpm was reported at 33-ft BGS as shown in Figure 4-8C (RHO-CD-896). The next recoverable reading was reported July 31,1972 with a peak of $31.7 \mathrm{~K} \mathrm{cpm}$ at $39-\mathrm{ft}$ BGS (see 01). Readings then gradually decreased to less than values by March 1986.

The 33-ft BGS level is equivalent to 60-in above the bottom center of the tank and is $\sim 2$-ft 6-in from the top of the tank footing. The tank was pumped in December 1969 to $~ 55$-in above the 
bottom center of the tank. A cascade line leak could have migrated down the sidewall soil column over a period of at least 17 months before being detected in drywell 30-01-01; however, a sidewall liner leak is also possible.

Figure 4-8. Drywell 30-01-01 Historical Gross Gamma Logging
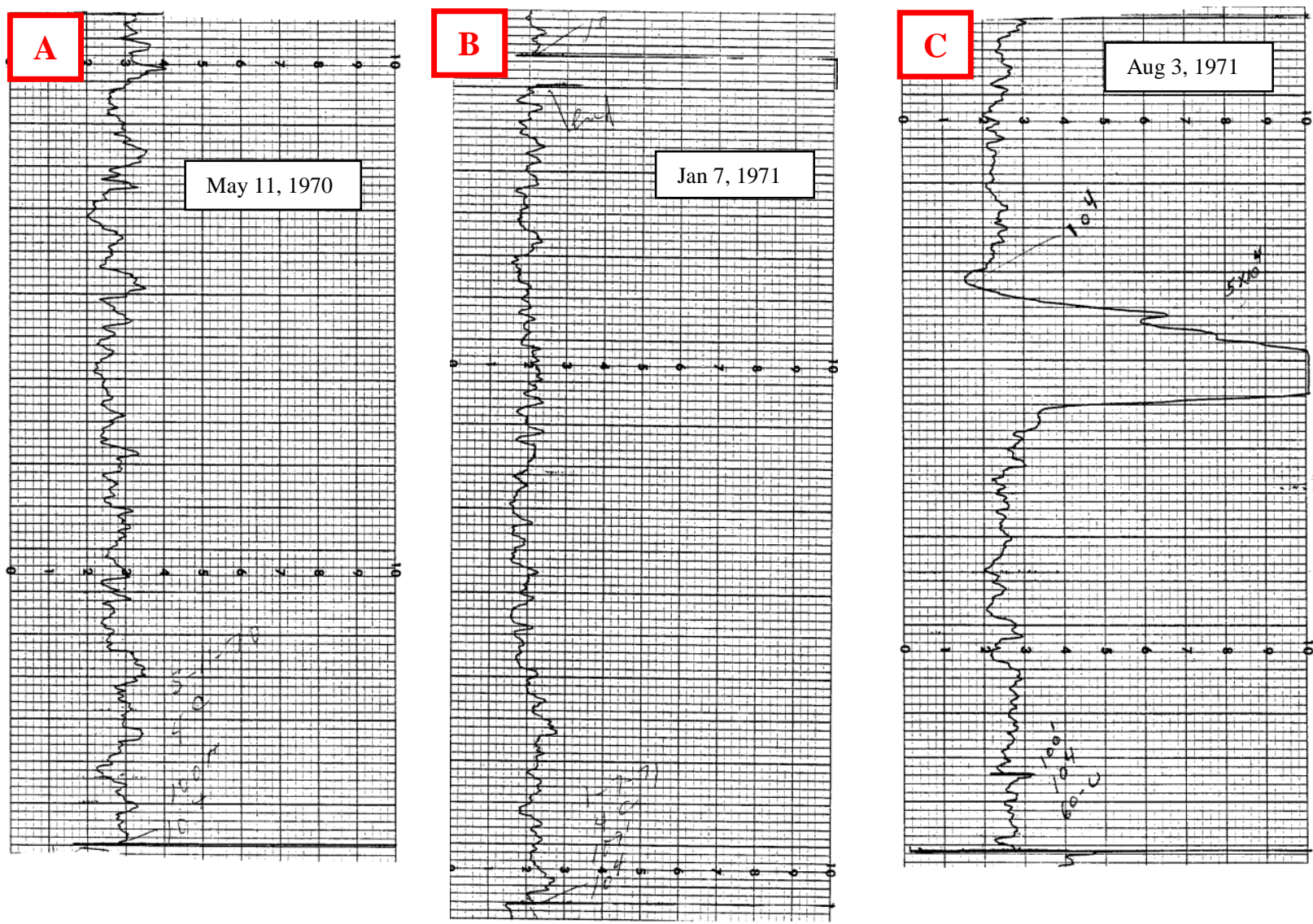

In September 1997, Cs-137 and Co-60 were the only man-made radionuclides detected in this drywell (GJ-HAN-85). From the ground surface to 13-ft BGS, Cs-137 was detected continuously and almost continuously from 20.5 to $32-\mathrm{ft}$ and from 97.5 to 98 -ft BGS. The maximum Cs-137 concentration was approximately $2 \mathrm{pCi} / \mathrm{g}$ at 29.5-ft BGS. From 37 to $41-\mathrm{ft}$ BGS, Co-60 was detected almost continuously with a maximum concentration of $0.16 \mathrm{pCi} / \mathrm{g}$ at 38 and 38.5-ft BGS. Document GJ-HAN-85 reports, "The Cs-137 from the ground surface to about $13 \mathrm{ft}$ may be the result of a surface spill"... and, "The Cs-137 contamination from 20.5 to $32 \mathrm{ft}$ may be from a pipeline leak."

Also stated in this document, "The Co-60 contamination from 37 to $41 \mathrm{ft}$ is probably the result of a tank leak. The driller's log notes elevated gross gamma activity at this depth during borehole construction in March 1970. Count rates of 10,000 counts per minute (cpm) were recorded with an unknown radiation survey instrument for samples taken from depths of 38, 40, 41, 42, 43, and $44 \mathrm{ft}$. Count rates of 5,000 cpm were recorded for a sample from $39 \mathrm{ft}$, and $800 \mathrm{cpm}$ were recorded for a sample from $45 \mathrm{ft}$." However, it remains uncertain whether these elevated gross gamma counts noted in the driller's log is referring to drywell 30-01-01 or 30-01-12 since the 
drywell or location was not specified in the driller's log. Figure 4-9 shows the depths of radioactivity from 1975 to 1995 (RPP-8321).

Figure 4-9. Tank C-101 Drywell 30-01-01 (RPP-8321)

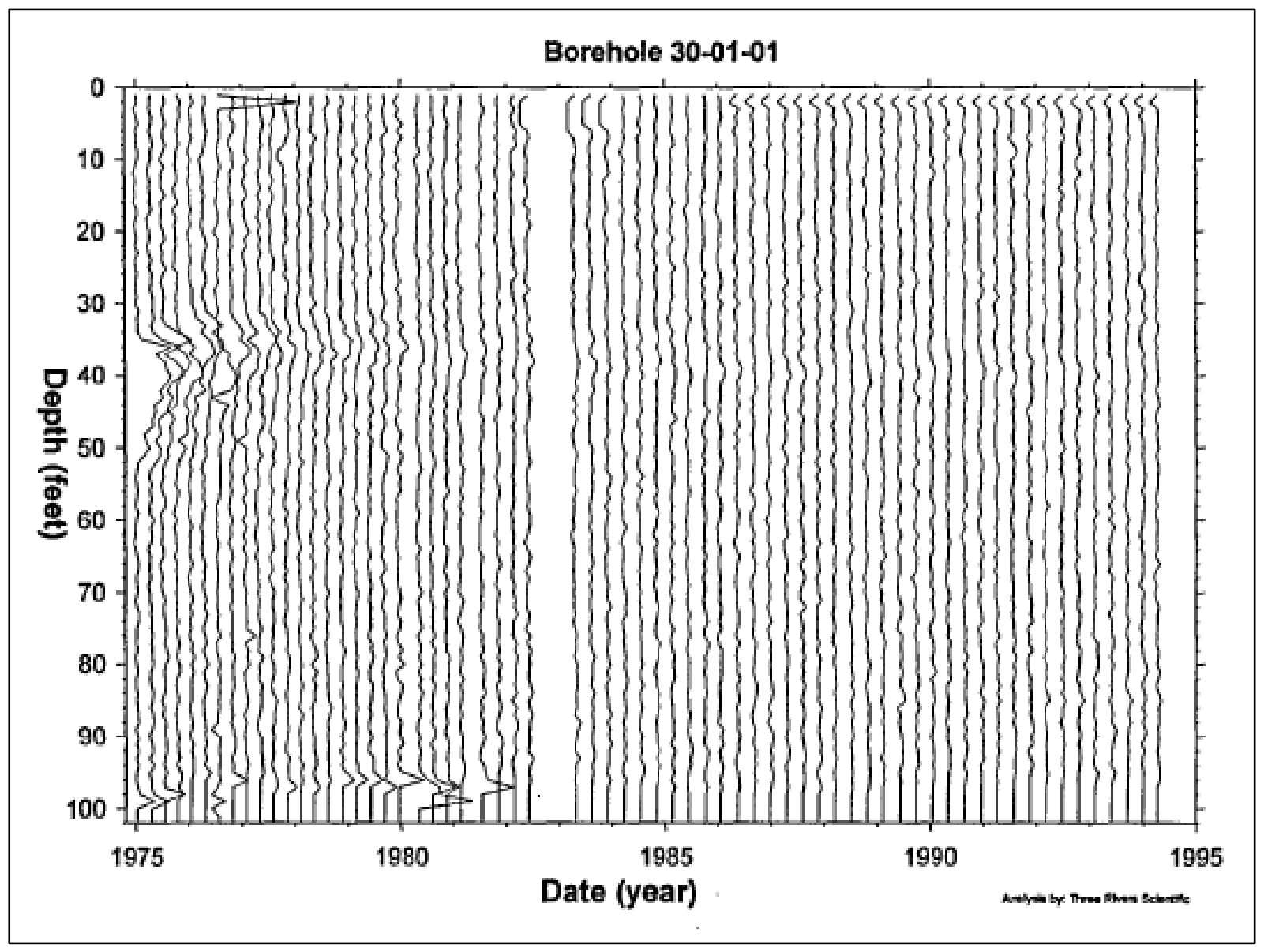

Note: Bottom of the tank footing is $\sim 37-\mathrm{ft} 6$-in BGS

\subsubsection{Drywell 30-01-06}

Drywell 30-01-06 was drilled on April 1970 with the first recoverable reading on April 7, 1970 (see Figure 4-10). This plot from 1970 indicates there are two peaks located at approximately 35-ft BGS at lower radioactivity levels and one larger peak below 70-ft BGS. The next recoverable reading was July 31,1972 which reported a peak of $\sim 100 \mathrm{~K}$ cpm at 78 -ft BGS (see 01). Readings declined quickly to half this value a year later and continued to decline to less than $10 \mathrm{~K}$ cpm by February 1976. An additional peak was first reported May 4, 1978 at 3.2K cpm at 34-ft BGS. From April 11, 1979 through June 1986, the peak at the 34-ft BGS level was the only peak recorded for drywell 30-01-06 and readings remained relatively stable between 6 to $7 \mathrm{~K} \mathrm{cpm}$.

In September 1997, Cs-137 and Co-60 were the only man-made radionuclides detected in drywell 30-01-06 (GJ-HAN-85). From the ground surface to 7.5-ft BGS, 14 to 20-ft BGS, 35 to 38.5-ft BGS, and 97.5 to 98.5 -ft BGS, Cs-137 contamination was detected continuously with the 
maximum concentration of $48.6 \mathrm{pCi} / \mathrm{g}$ at $37-\mathrm{ft} \mathrm{BGS}$. The Co-60 contamination was detected only at 37-ft BGS with a concentration of $0.1 \mathrm{pCi} / \mathrm{g}$. Document GJ-HAN-85 states, "The Cs-137 contamination from 35 to $38.5 \mathrm{ft}$ probably migrated from a tank leak and accumulated at the base of the tank farm excavation." Figure 4-11 shows the depths of radioactivity from 1975 to 1995 (RPP-8321).

Figure 4-10. Drywell 30-01-06 Historical Gross Gamma Logging April 7, 1970

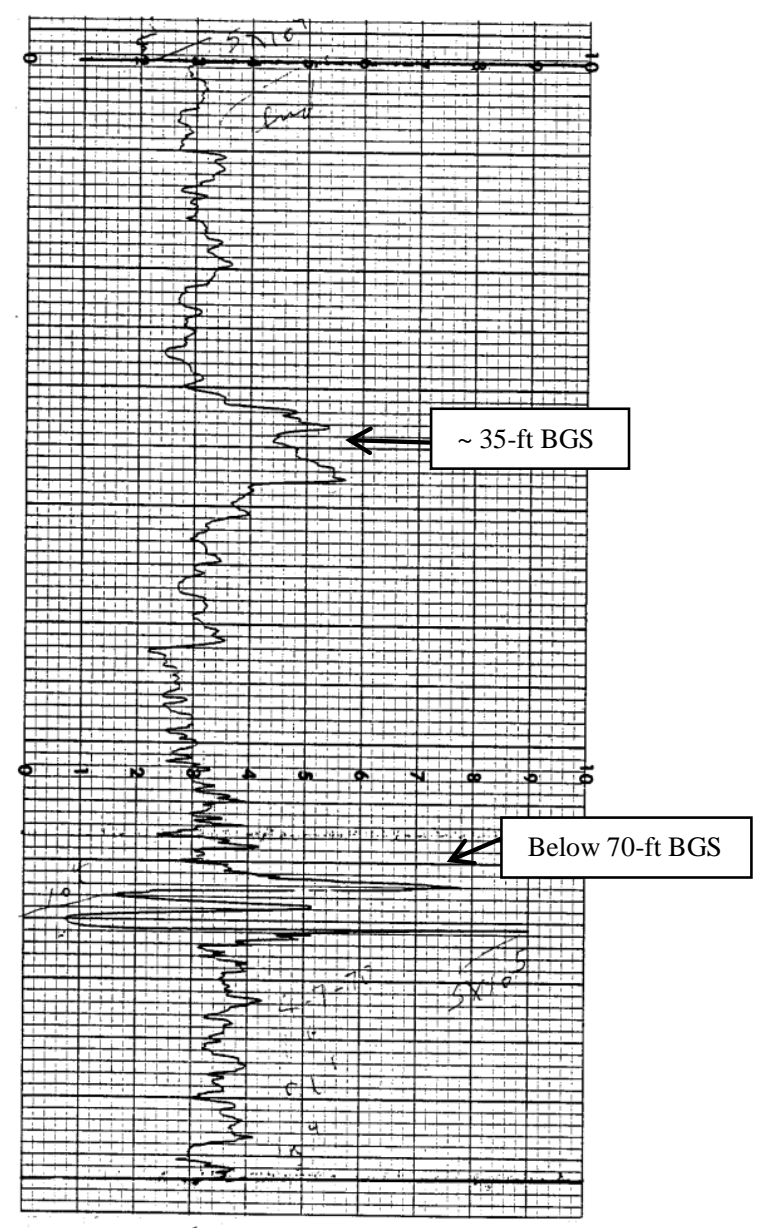

The y-axis covers $\sim 100$-ft starting at grade level 
RPP-RPT-54914, Rev. 0

Figure 4-11. Tank C-101 Drywell 30-01-06 (RPP-8321)

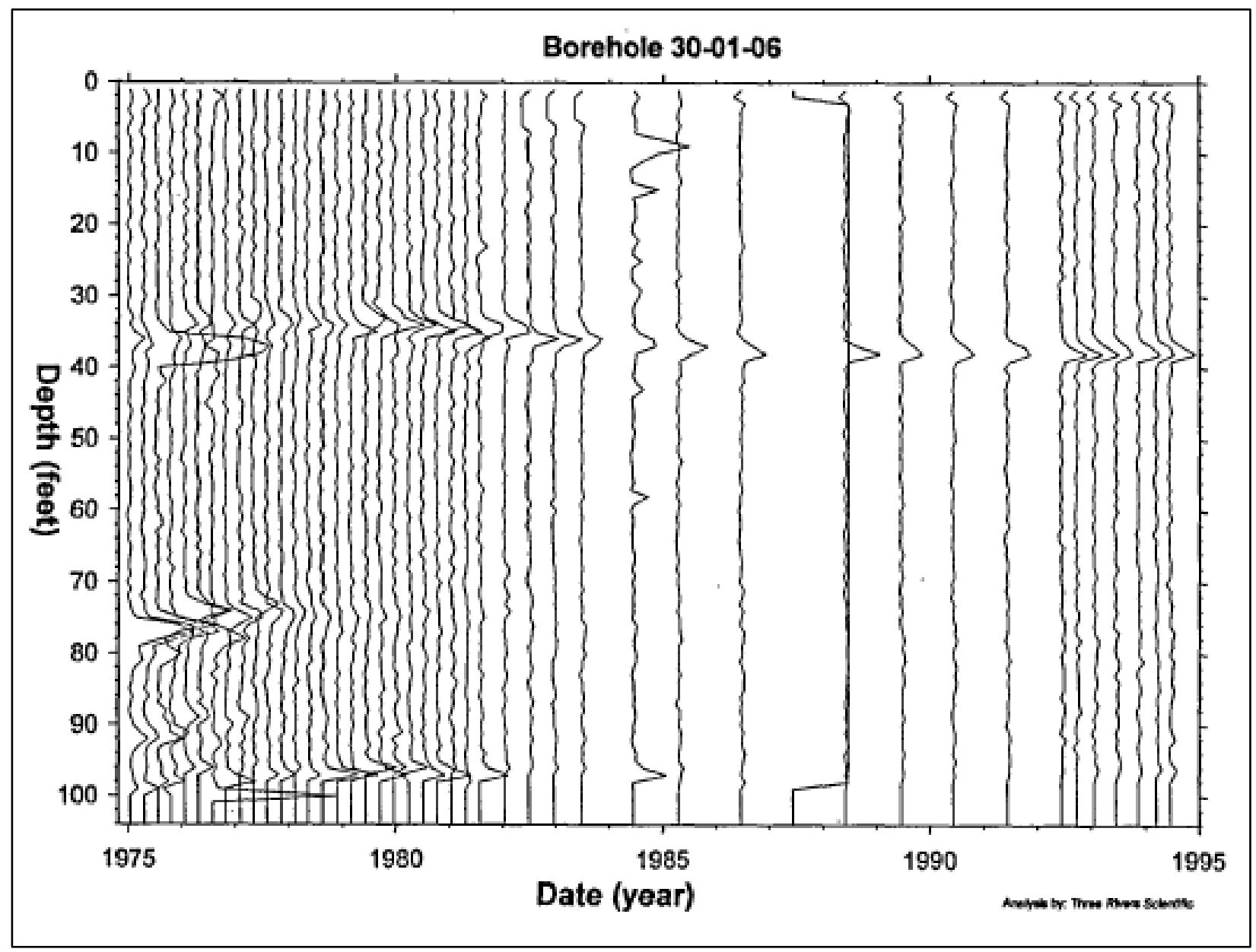

Note: Bottom of the tank footing is 37-ft 6-in BGS 


\subsubsection{Drywell 30-00-06}

Drywell 30-00-06 is located approximately 20-ft from the southwest side of tank C-101 and is located in the side of a hill with the top of the 8-in casing 7-ft above the tank farm ground surface. Drywell 30-00-06 was drilled on December 31, 1944 with the first recoverable readings reported as less than values on September 9, 1959 and September 21, 1960 (see 01). The next recoverable reading on January 27, 1966 reported three peaks of 6, 8, and $10 \mathrm{~K} \mathrm{cpm}$ at 50,100, and 134-ft BGS, respectively. Readings remained relatively stable through November 1966. The next recoverable readings are shown in Figure 4-12, no raw data was recovered after 1966 for this drywell.

In September 1997, Cs-137 and Co-60 were the only man-made radionuclides detected in drywell 30-00-06 (GJ-HAN-58). From the ground surface to 5-ft BGS and from 57 to 111-ft BGS, Cs-137 was detected intermittently. Only at 77.5-ft BGS was Co-60 detected. The maximum concentrations of Cs-137 and Co-60 could not be measured in this drywell due to the double casing. Therefore, the origin of the Cs-137 concentration below 56-ft BGS cannot be determined (GJ-HAN-58). Since historical records report little radioactivity in this drywell and contamination at unknown concentrations were found below 56- $\mathrm{ft}$ BGS, drywell 30-00-06 is not being included as part of the leak location for tank C-101. Figure 4-12 shows the depths of radioactivity from 1975 to 1995 (RPP-8321).

Figure 4-12. Tank C-101 Drywell 30-00-06 (RPP-8321)

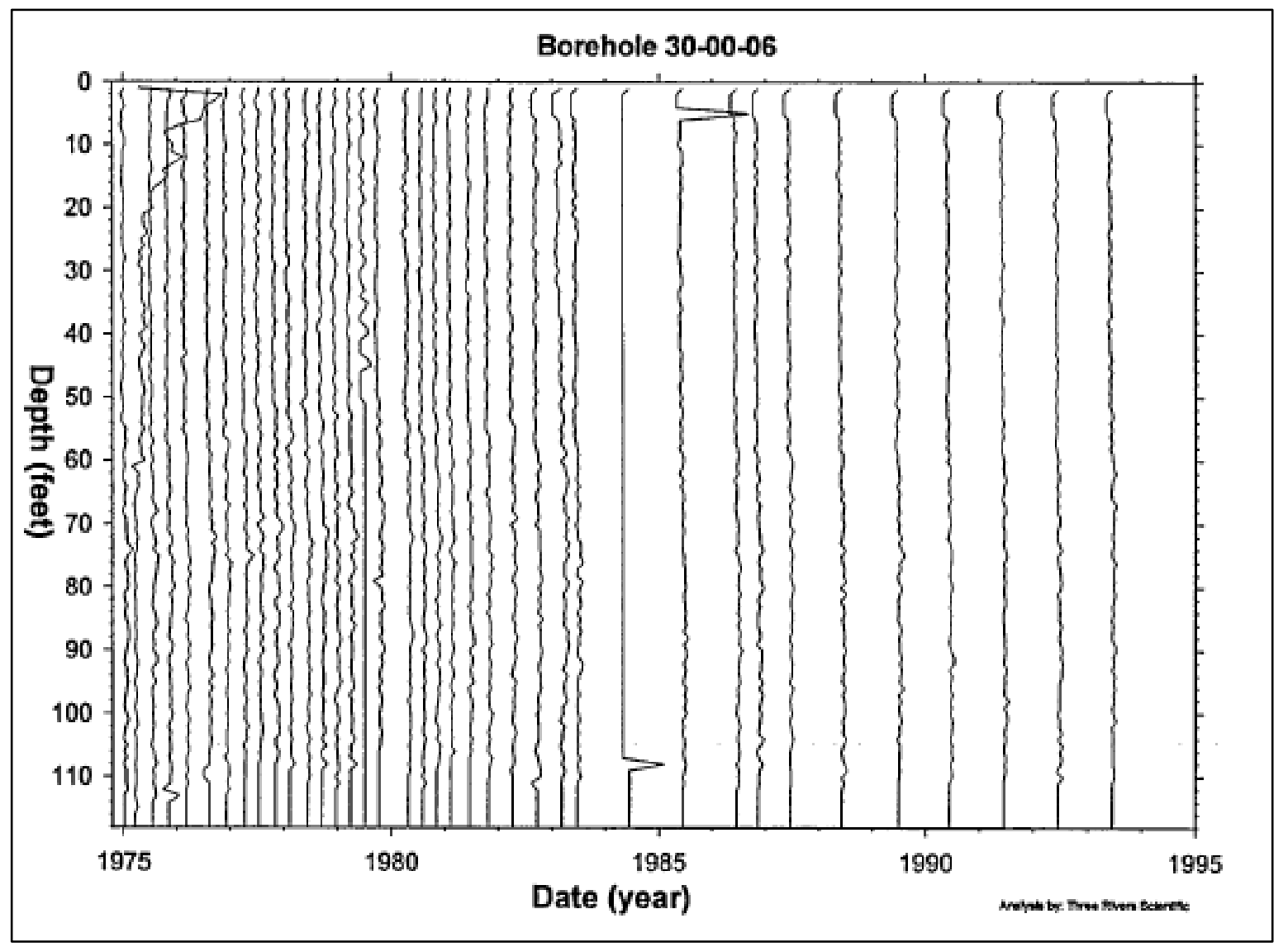

Note: Bottom of the tank footing is $\sim 37$-ft 6 -in BGS 


\subsubsection{Drywell 30-01-09}

Drywell 30-01-09 was drilled on February 10, 1970 with the first recoverable reading on April 7, 1970 which indicated a saturated zone between $~ 23$ and 36-ft BGS with multiple smaller peaks down to 87-ft BGS (see Figure 4-13). The next recoverable reading on July 31, 1972 reported a peak of $\sim 1,000 \mathrm{~K}$ cpm at 30 -ft BGS. Readings remained relatively stable at this level through June 1986 (see 01).

In September 1997, Cs-137, Co-60, Eu-154, and Eu-152 were the only man-made radionuclides detected in drywell 30-01-09 (GJ-HAN-58). Continuous Cs-137 contamination was detected from the ground surface to 6-ft BGS, 24.5 to 32-ft BGS, and 34.5 to 37-ft BGS with the maximum concentration of $568.4 \mathrm{pCi} / \mathrm{g}$ measured at 28.5-ft BGS. From 9 to $16.5-\mathrm{ft}$ BGS and at 97.5-ft BGS, Cs-137 contamination was detected nearly continuously. At 39.5 and 40-ft BGS, Co-60 was detected with the maximum concentration of $0.15 \mathrm{pCi} / \mathrm{g}$ at $40-\mathrm{ft}$ BGS. At $27.5-\mathrm{ft}$ BGS, both Eu-152 and Eu-154 were detected at concentrations of 128.9 and $106.7 \mathrm{pCi} / \mathrm{g}$, respectively.

Document GJ-HAN-58 reported, "The Cs-137 contamination from 24.5 to $32 \mathrm{ft}$ and the Eu-152 and Eu-154 contamination at $27.5 \mathrm{ft}$ is probably the result of a tank leak at approximately this depth." However, a leak from the inlet lines is also a possibility as discussed in Section 4.4.1. Figure 4-14 shows the depths of radioactivity from 1975 to 1995 (RPP-8321).

Figure 4-13. Drywell 30-01-09 Historical Gross Gamma Logging April 7, 1970

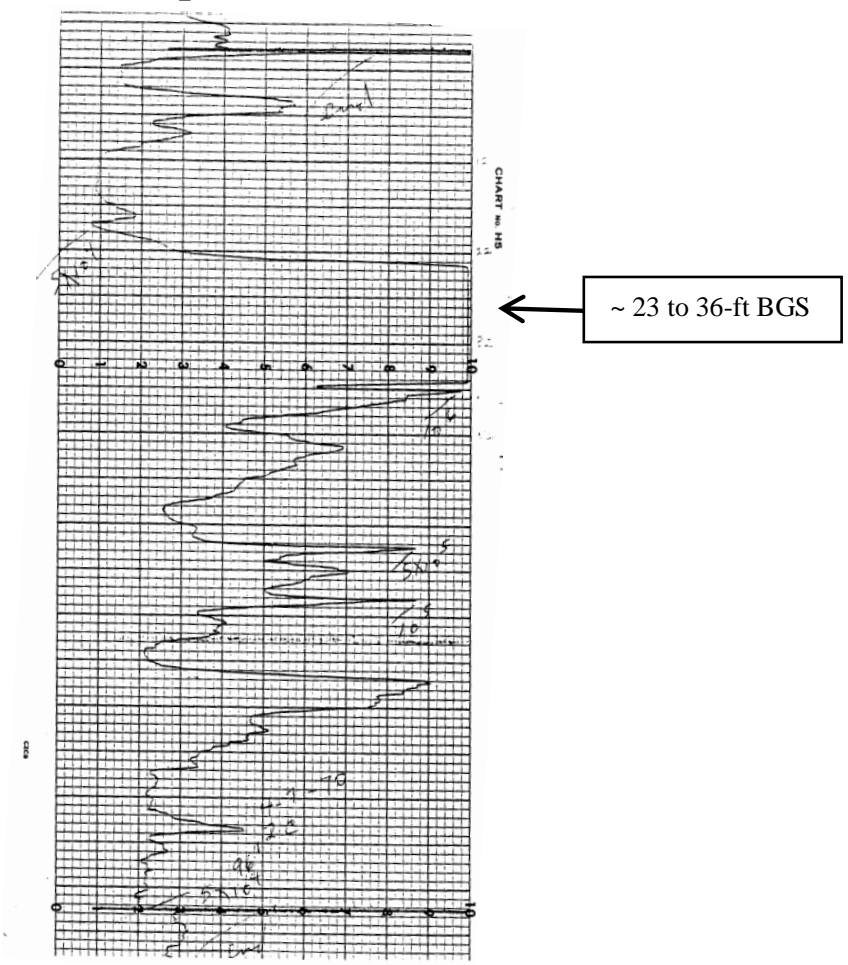

The $\mathrm{y}$-axis covers $\sim 100$-ft starting at grade level 
RPP-RPT-54914, Rev. 0

Figure 4-14. Tank C-101 Drywell 30-01-09 (RPP-8321)

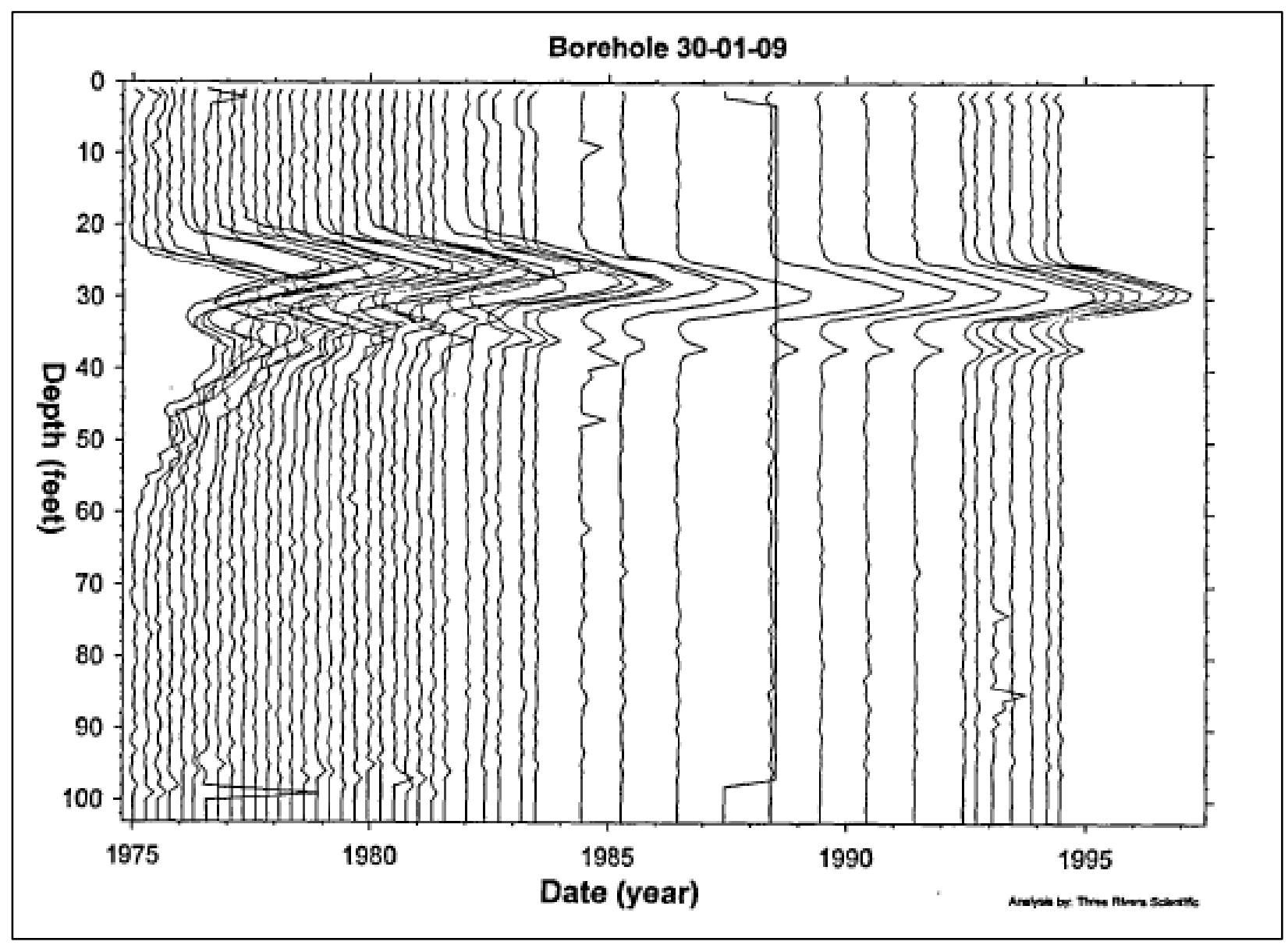

Note: Bottom of the tank footing is 37-ft 6-in BGS 
RPP-RPT-54914, Rev. 0

\subsubsection{Drywell 30-04-05}

Drywell 30-04-05 was drilled on July 31, 1974 with the first recoverable reading on September 9, 1974 with a peak of $28.6 \mathrm{~K} \mathrm{cpm}$ at $13-\mathrm{ft}$ BGS (see 01). Radiation levels remained relatively stable and on January 24, 1975 an additional peak was recorded at $3 \mathrm{~K} \mathrm{cpm}$ at $22-\mathrm{ft}$ BGS. The next recoverable reading reported one peak on July 7, 1975 at $2.7 \mathrm{~K} \mathrm{cpm}$ at 23 -ft BGS. By February 1976 through February 1987, readings were reported as less than values in drywell 3004-05.

In September 1997, Cs-137 was the only man-made radionuclides detected in drywell 30-04-05 (GJ-HAN-85). From the ground surface to 57.5-ft BGS and from 94.5 to 98.5 -ft BGS, Cs-137 was detected almost continuously with the maximum concentration of $91.5 \mathrm{pCi} / \mathrm{g}$ measured at 12.5-ft BGS. From 69.5 to 91.5-ft BGS, Cs-137 was detected intermittently. Document GJHAN-85 reported, "The Cs-137 contamination from 11 to $38 \mathrm{ft}$ is probably the result of a surface spill that migrated into the backfill material around the borehole" and "The Cs-137 contamination from 45 to $57.5 \mathrm{ft}$ is probably from a tank leak that migrated into the Hanford formation sediments beneath the tank farm excavation." The Cs-137 contamination from 45 to 57.5-ft BGS is below $10 \mathrm{pCi} / \mathrm{g}$ and could be migration from the leak site near drywell 30-01-09. Figure 4-15 shows the depths of radioactivity from 1975 to 1995 (RPP-8321).

Figure 4-15. Tank C-101 Drywell 30-04-05 (RPP-8321)

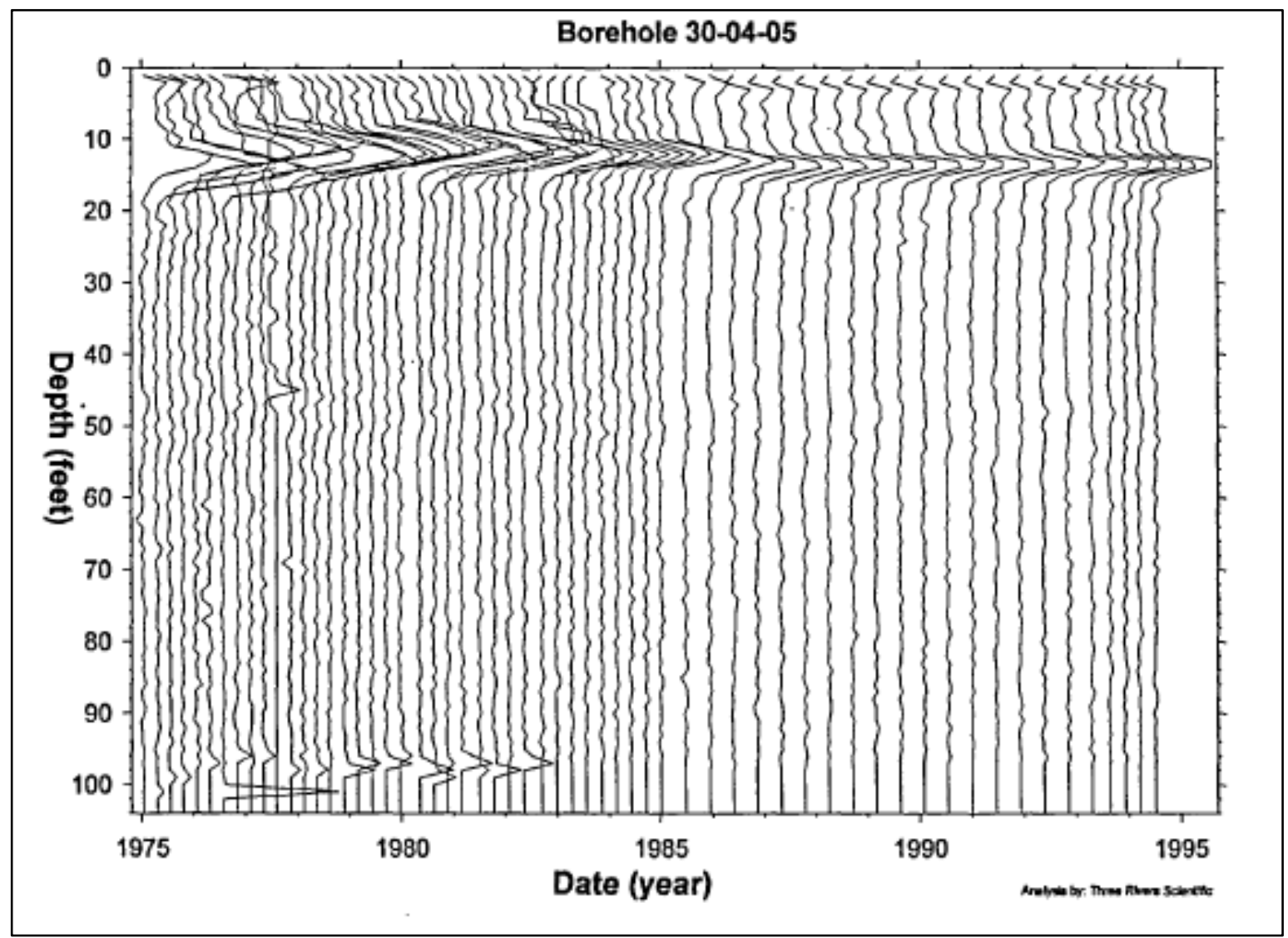

Note: Bottom of the tank footing is 37-ft 6-in BGS 
RPP-RPT-54914, Rev. 0

\subsubsection{Drywell 30-01-12}

Drywell 30-01-12 was drilled in March1970 with the first recoverable reading on July 31, 1972 reported as less than values (see 01). Readings continued to be recorded as less than values through February 1987.

In September 1997, Cs-137 was the only man-made radionuclides detected in drywell 30-01-12 (GJ-HAN-58). From the ground surface to 40.5-ft BGS, Cs-137 contamination was detected almost continuously with the maximum concentration of $85.2 \mathrm{pCi} / \mathrm{g}$ detected at $4.5-\mathrm{ft}$ BGS. Isolated occurrences of Cs-137 were also detected at 45, 60, 66.5, and 99.5-ft BGS. Document GJ-HAN-58 indicates that radioactivity detected in this drywell is likely associated from surface spills or a pipeline leak that migrated down into the backfill around this drywell and/or dragdown. Therefore, drywell 30-01-12 is not included as part of the leak location for tank C101. Figure 4-16 shows the depths of radioactivity from 1975 to 1995 (RPP-8321).

Figure 4-16. Tank C-101 Drywell 30-01-12 (RPP-8321)

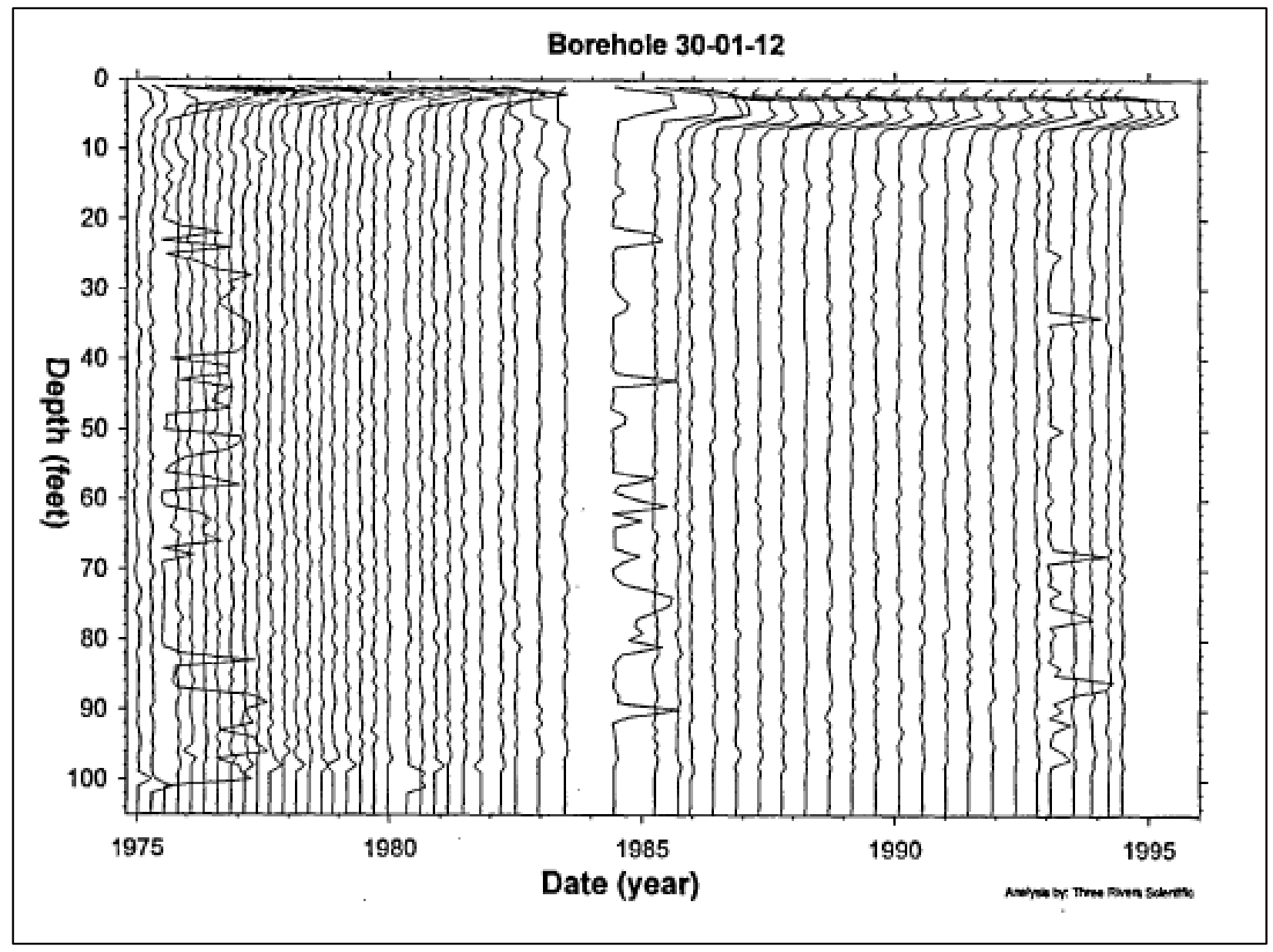

Note: Bottom of the tank footing is $\sim 37$-ft 6 -in BGS 


\subsubsection{2011 Direct Pushes}

In 2011, four direct push slant holes (C8101, C8102, C8103, and C8104) were installed near tank C-101 (see Figure 4-17). Gross gamma logging was conducted in direct pushes C8101 and C8103 while direct pushes C8102 and C8104 were used for sampling.

Results indicate low gamma activity throughout the logged profile in both direct push C8101 and C8103. Sample results showed low nitrate concentrations and Tc-99 was not detected except at low concentrations deep in direct push C8104. Therefore, the direct pushes installed in 2011 do not provide additional information for the leak location of tank C-101 (RPP-RPT-50581, Completion Report for the C Tank Farm, C-101 Angle Push Characterization).

Figure 4-17. Tank C-101 Direct Push Location

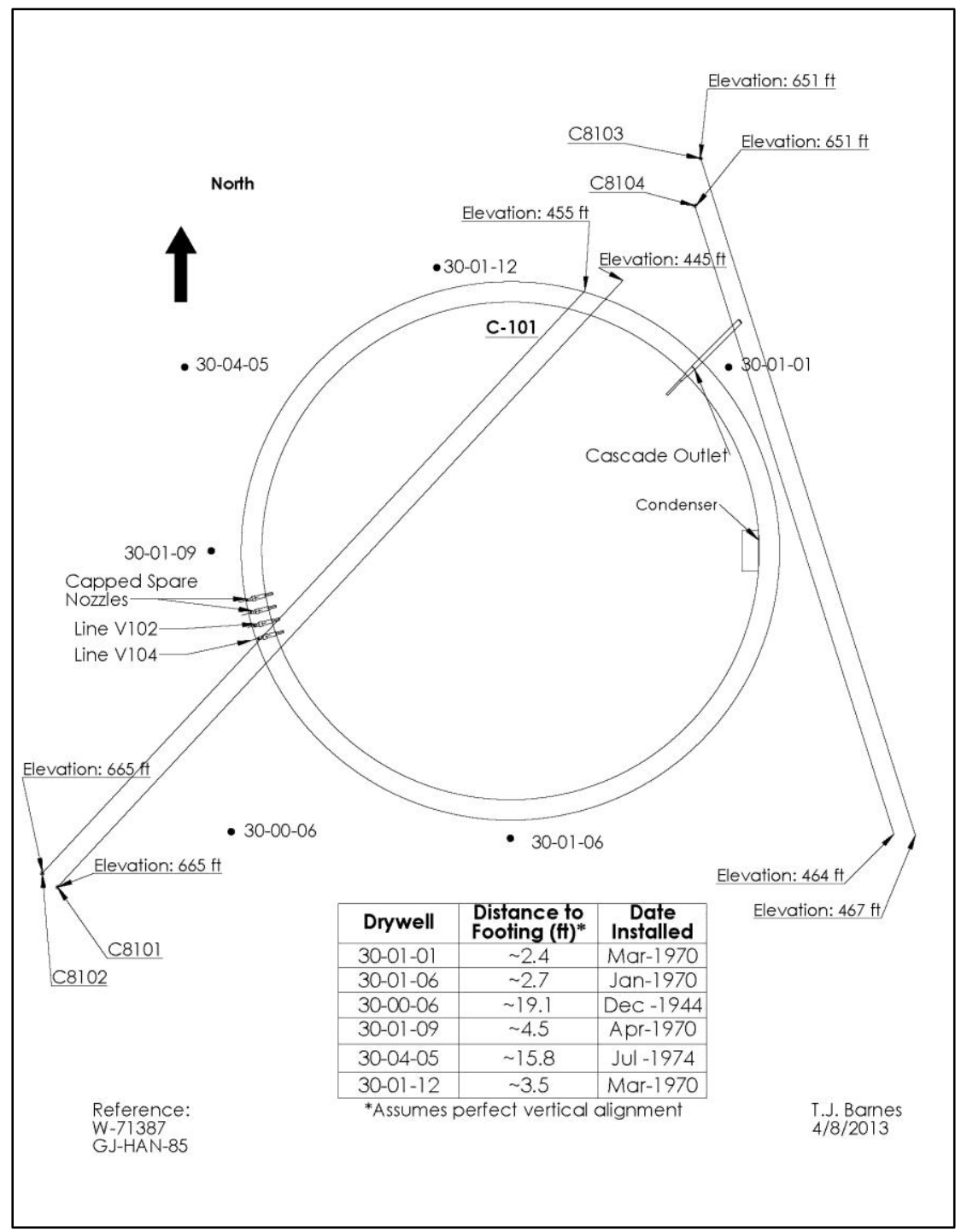

Note: Tank C-101 dome apex is at an elevation of $641.43-\mathrm{ft}$, grade surface is at $647-\mathrm{ft}$, and bottom of the tank footing is at $609.58-\mathrm{ft}$ 
RPP-RPT-54914, Rev. 0

\subsubsection{Drywell Summary}

If there was a leak from tank C-101 then it could have occurred as early as June 1965 based on liquid level decreases (see Section 4.4.1). Only drywell 30-00-06 was installed near tank C-101 during this time.

Tank C-101 drywells 30-00-06 and 30-01-12 do not indicate any radioactivity associated with a tank C-101 leak. Therefore, these drywells are not included in the leak location for tank C-101.

The first recoverable readings in April 1970 for drywells 30-01-06 and 30-01-09 indicate radioactivity. A peak was reported in drywell 30-01-09 at $1000 \mathrm{~K} \mathrm{cpm}$ at 30-ft BGS and a peak at a lower radioactivity level was reported in drywell 30-01-06 at 35-ft BGS. It is possible there is a tank sidewall leak near drywell 30-01-09 with possible migration to a lower level detected in drywell 30-01-06. The capped spare nozzles are located near drywell 30-01-09 (see Figure 4-17) at approximately the $20-\mathrm{ft}$ BGS level. It is also possible the radioactivity detected in drywells 30-01-06 and 30-01-09 are the result of a leak from the inlet plugs and sleeves as tank C-101 was filled above the capped spare inlet nozzles between 1965 and 1969 (see Section 4.2). Liquid level analysis also supports a leak from the capped spare inlet nozzles (see Section 4.4.1). The source of the radioactivity detected in these drywells remains inconclusive.

The first recoverable reading for drywell 30-04-05 reported a peak at 13-ft BGS in September 1974 which is likely due to migration from a surface and/or pipeline leak. In September 1997, Cs-137 contamination was detected further down in this drywell (45 to 57.5-ft BGS) which is likely migration from the leak plume originating near drywell 30-01-09.

The first recoverable indication of radioactivity in drywell 30-01-01 was in August 1971 with a peak of $27 \mathrm{~K} \mathrm{cpm}$ reported at 33-ft BGS. The 33-ft BGS level is equivalent to 60 -in above the bottom center of the tank and is $\sim 2$-ft 6 -in from the top of the tank footing. Two previous readings in May 1970 and January 1971 indicated very little radioactivity in this drywell. The tank was pumped in December 1969 to $~ 55$-in above the bottom center of the tank. A cascade line leak could have migrated down the sidewall soil column over a period of at least 17 months before being detected in drywell 30-01-01. It appears this drywell remains separate from the initial radioactivity detected in nearby drywells of tank C-101 in 1970. It is possible radioactivity detected in this drywell could be from a cascade outlet line leak (located at approximately the 21-ft BGS level), and/or a sidewall leak from tank C-101. However, it remains inconclusive.

No laterals were installed near tank C-101. Also, the direct push slant drywells did not indicate a tank leak.

\subsection{POSSIBLE TANK C-101 LINER LEAK LOCATION(S)}

A liner leak may have penetrated the waterproof membrane at any location or pooled on the waterproof membrane and followed concrete cracks or construction joints to a different location for egress to the soil, including the top of the tank footing.

Tank C-101 had at least one leak site (see Section 4.6.1) which could be a possible sidewall leak based on drywell radioactivity or could also be attributed to leaking inlet sidewall 
connections. A detailed liquid level analysis (Appendix A) indicated there could have been a sidewall leak above an ENRAF liquid level of 40-in (34-ft 8-in BGS). However, much of the evidence indicated the liquid level decrease observed, which was above the capped spare inlet nozzles and cascade line, could also have been from a cascade line packing leak, seepage past a partially blocked cascade line, or leaking capped spare inlet nozzles. There is also the possibility of uncondensed atmospheric condenser vapor or gasket leaks.

\subsubsection{Leak Detected in April 1970}

If there was a leak from tank C-101, it could have occurred as early as June 1965 based on liquid level decreases (see Section 4.4.1). The liquid level was above the spare inlet lines as well as the cascade outlet line level in June 1965 when the liquid level initially started to drop. Tank C-101 waste was pumped out of the tank in December 1969, before the liquid level dropped below the cascade outlet line level. Therefore, it cannot be determined if some of the liquid level decrease was the result of a tank leak and/or other sources (see Section 4.4.1). A detailed liquid level analysis indicated the possibility that the capped spare inlet nozzles and cascade line packing could have leaked or there may have been seepage through the cascade line. It was also determined that if the tank did leak, the leak would probably have occurred above the 40-in ENRAF measured liquid level as measured from the bottom of the tank center.

In April 1970, drywell 30-01-09 reported contamination between 23 and 36-ft BGS (see site A in Figure 4-18). Drywell 30-01-09 is located near the capped spare nozzles and the capped spare nozzles are located 20-ft BGS. Drywell 30-01-06 also reported a peak in April 1970 at lower radioactivity levels at $\sim 35-\mathrm{ft}$ BGS. Therefore, it is likely the source of the radioactivity is near drywell 30-01-09 with likely migration to drywell 30-01-06. The source of the drywell readings remains inconclusive but could be due to a capped spare inlet nozzle leak or a tank sidewall leak located near drywell 30-01-09. 
RPP-RPT-54914, Rev. 0

Figure 4-18. Tank C-101 Possible Leak Location (April 1970)

Tank inner ring is steel liner; outer ring is outer edge of tank footing

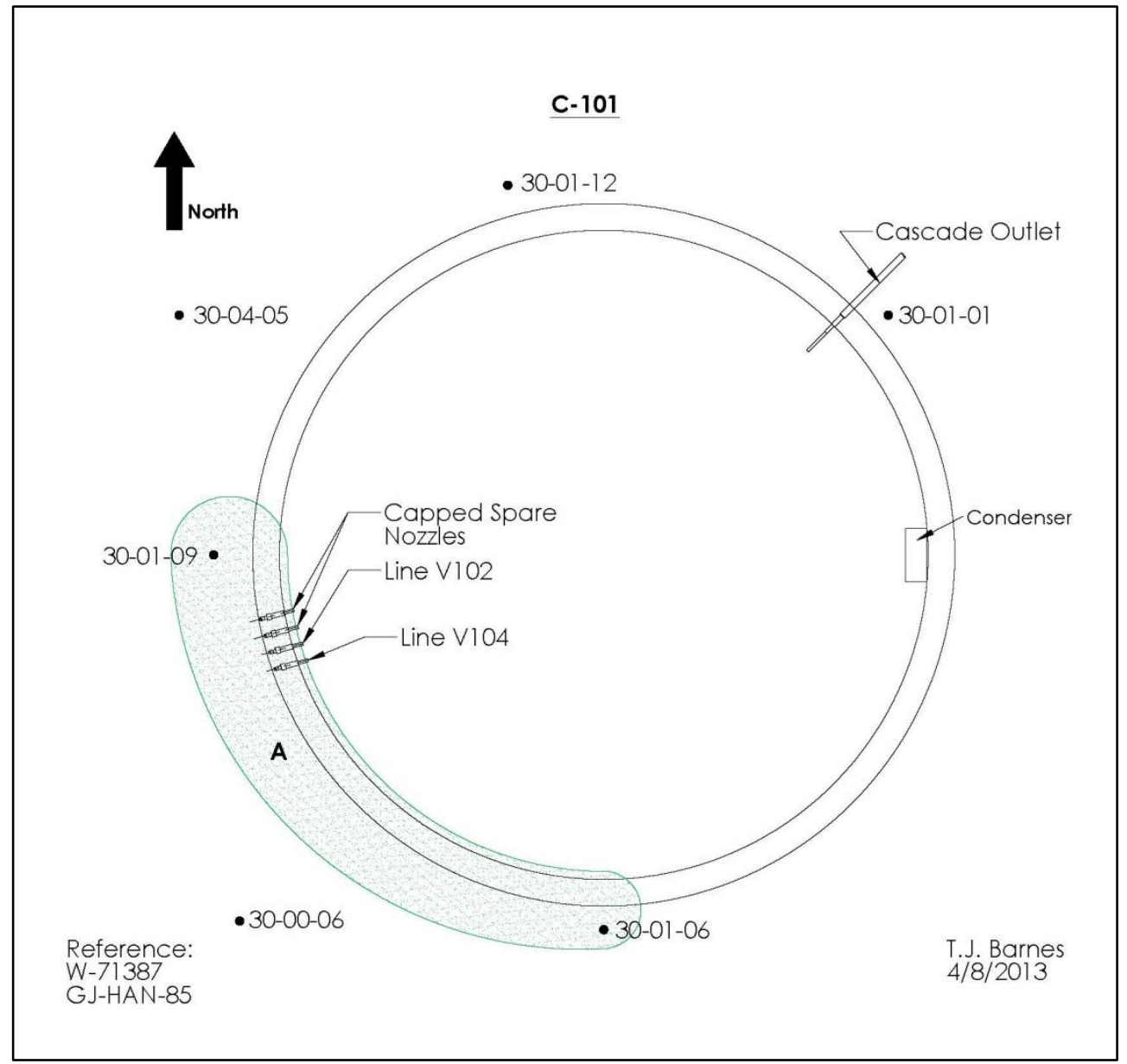

If there was a leak from tank C-101, it could have occurred as early as June 1965 based on liquid level decreases 


\subsubsection{Leak Detected in August 1971}

In August 1971, a new peak was reported in drywell 30-01-01 at approximately 33-ft BGS (see site B in Figure 4-19). This appears to be a separate site unrelated to the radioactivity detected in the southwestern portion of tank C-101 (see site A in Figure 4-18). The cascade outlet line is located at approximately $21-\mathrm{ft}$ BGS. It is likely the radioactivity detected in drywell 30-01-01 is due to a leak from the cascade outlet line that followed the support column down to the base of the tank. The cascade outlet line from tank C-101 to tank C-102 was reported to have been plugged previously and cascade outlet line leaks have been reported in other cases. There also is a possibility of a sidewall leak.

Figure 4-19. Tank C-101 Possible Leak Location (August 1971)

Tank inner ring is steel liner; outer ring is outer edge of tank footing

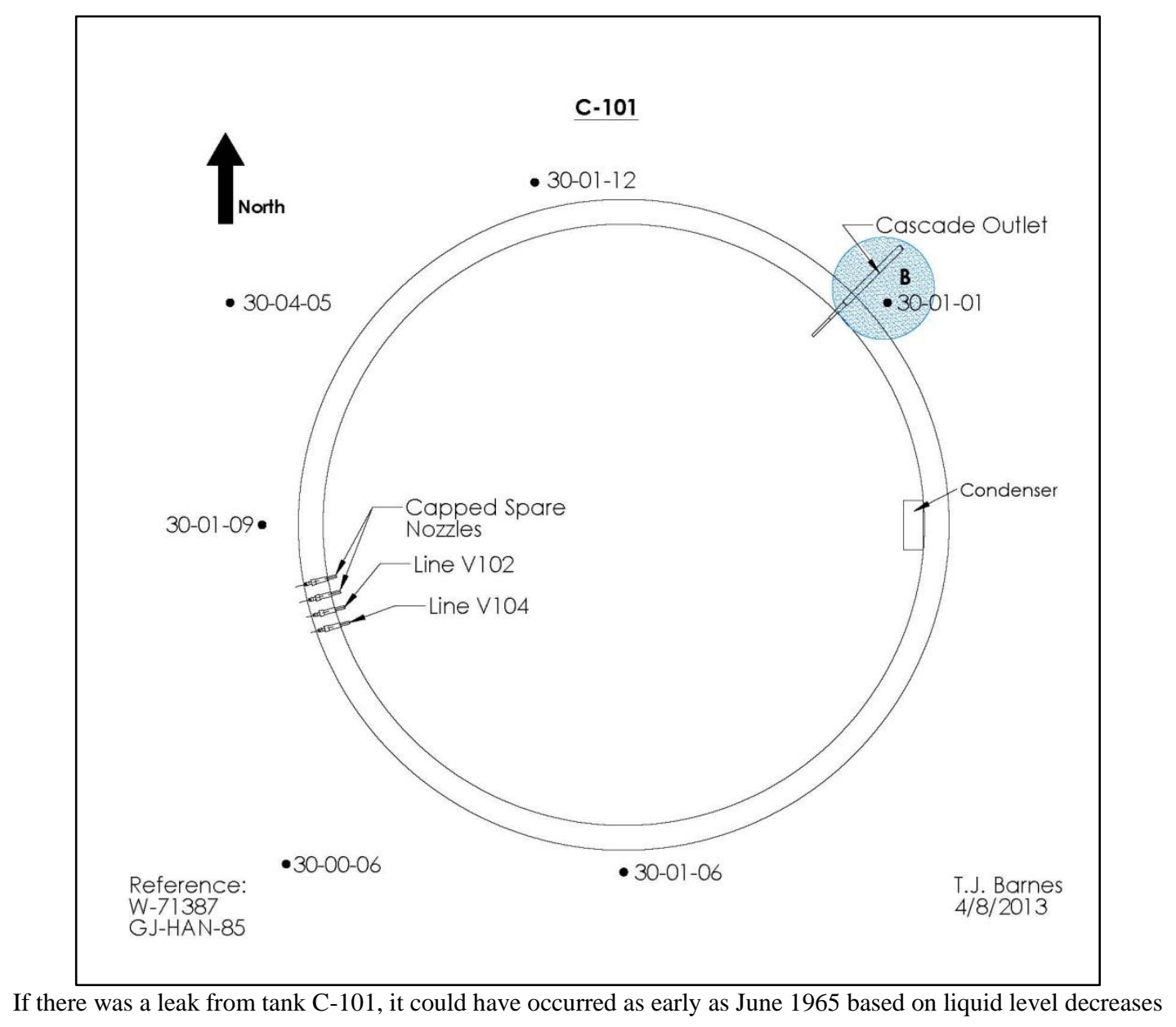




\subsubsection{Leak Detected in September 1974}

Drywell 30-04-05 reported radioactivity in September 1974, shortly after being drilled, with a peak at approximately 13-ft BGS (see site C in Figure 4-20). It appears radioactivity detected in this drywell is likely due to migration from a surface spill with the remote possibility of a pipeline leak. Site C in Figure 4-20 appears to be separate and unrelated to the earlier 1970 site A (see Figure 4-18) due to the BGS depth. The source of the radioactivity detected in drywell 30-04-05 does not appear to be from tank C-101.

Figure 4-20. Tank C-101 Possible Leak Location (September 1974)

Tank inner ring is steel liner; outer ring is outer edge of tank footing

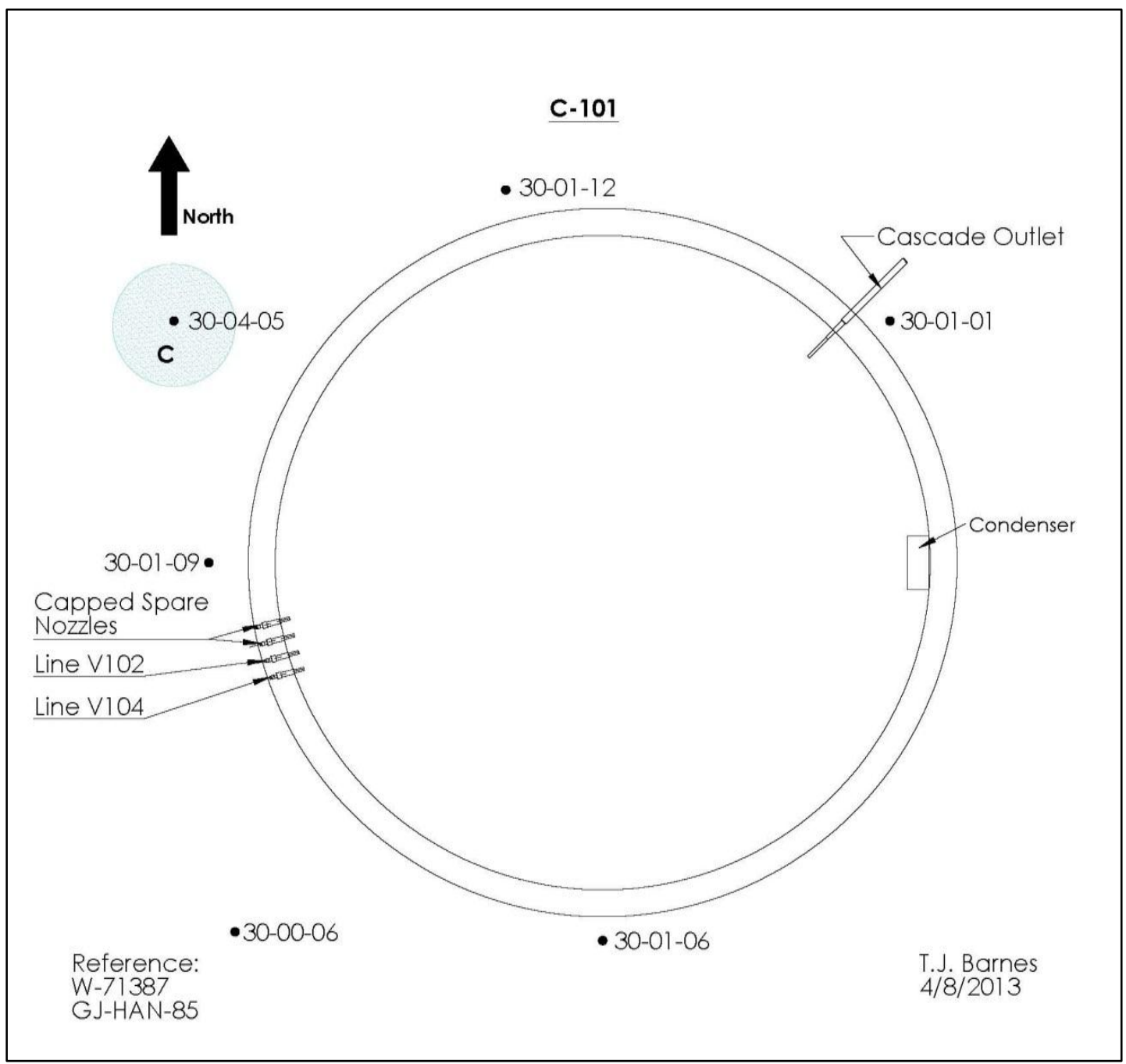

If there was a leak from tank C-101, it could have occurred as early as June 1965 based on liquid level decreases 
RPP-RPT-54914, Rev. 0

\subsubsection{Leak Location Summary}

Tank C-101 was first suspected of leaking based on a liquid level decrease of 4-in between approximately January 1968 and December 1969 (RHO-CD-896); however, if tank C-101 did leak, it appears the leak could have started as early as June 1965 based on liquid level decreases (see Section 4.4.1). A tank leak and/or a leak from other sources (i.e., capped spare nozzles, cascade outlet lines) cannot be determined as the liquid level was above the capped spare inlet nozzles as well as the cascade outlet line level in June 1965 when the liquid level initially started to drop. A detailed liquid level analysis indicated the possibility that the inlet line and cascade line packing could have leaked or there may have been seepage through the cascade line. It was also determined that if the tank did leak, the leak would probably have occurred above the 40-in ENRAF measured liquid level as measured from the bottom of the tank center.

In April 1970, drywell 30-01-09 reported a saturated zone between 23 and 36-ft BGS (see site A in Figure 4-21). Drywell 30-01-09 is located near the spare inlet lines and the spare inlet lines are located 22-ft BGS. Drywell 30-01-06 also reported a peak in April 1970 at lower radioactivity levels at $\sim 35$-ft BGS. Therefore, it is likely the source of the radioactivity is near drywell 30-01-09 with likely migration to drywell 30-01-06. The source of the drywell readings remains inconclusive but could be due to a capped spare inlet nozzle leak or a tank sidewall leak located near drywell 30-01-09.

In August 1971, a new peak was reported in drywell 30-01-01 at approximately 33-ft BGS (see site B in Figure 4-21). This appears to be a separate site unrelated to the radioactivity detected in the southwestern portion of tank C-101 (see site A in Figure 4-21). The cascade outlet line is located at approximately 21-ft BGS and it is likely the radioactivity detected in drywell 30-01-01 is due to a leak from the cascade outlet line.

In September 1974, drywell 30-04-05 reported radioactivity shortly after being drilled with a peak at approximately 13-ft BGS (see site C in Figure 4-21). It appears radioactivity detected in this drywell is likely due to migration from a surface spill with the remote possibility of a pipeline leak. Site C in Figure 4-20 appears to be separate and unrelated to the earlier 1970 site A (see Figure 4-21) due to the BGS depth. The source of the radioactivity detected in drywell 30-04-05 does not appear to be tank C-101.

Leak locations in Figure 4-21 are based on peak readings and are a representation of possible initial boundaries of radioactivity.

No evidence was found for a liner bulge occurring in tank C-101, and it remains unclear if a liner bulge once existed in the tank during its operation. However, tank C-101 non-boiling temperatures are not likely to be a factor in causing a liner bulge. 
Figure 4-21. Tank C-101 Possible Radial Leak Locations

Tank inner ring is steel liner, outer ring is outer edge of tank footing

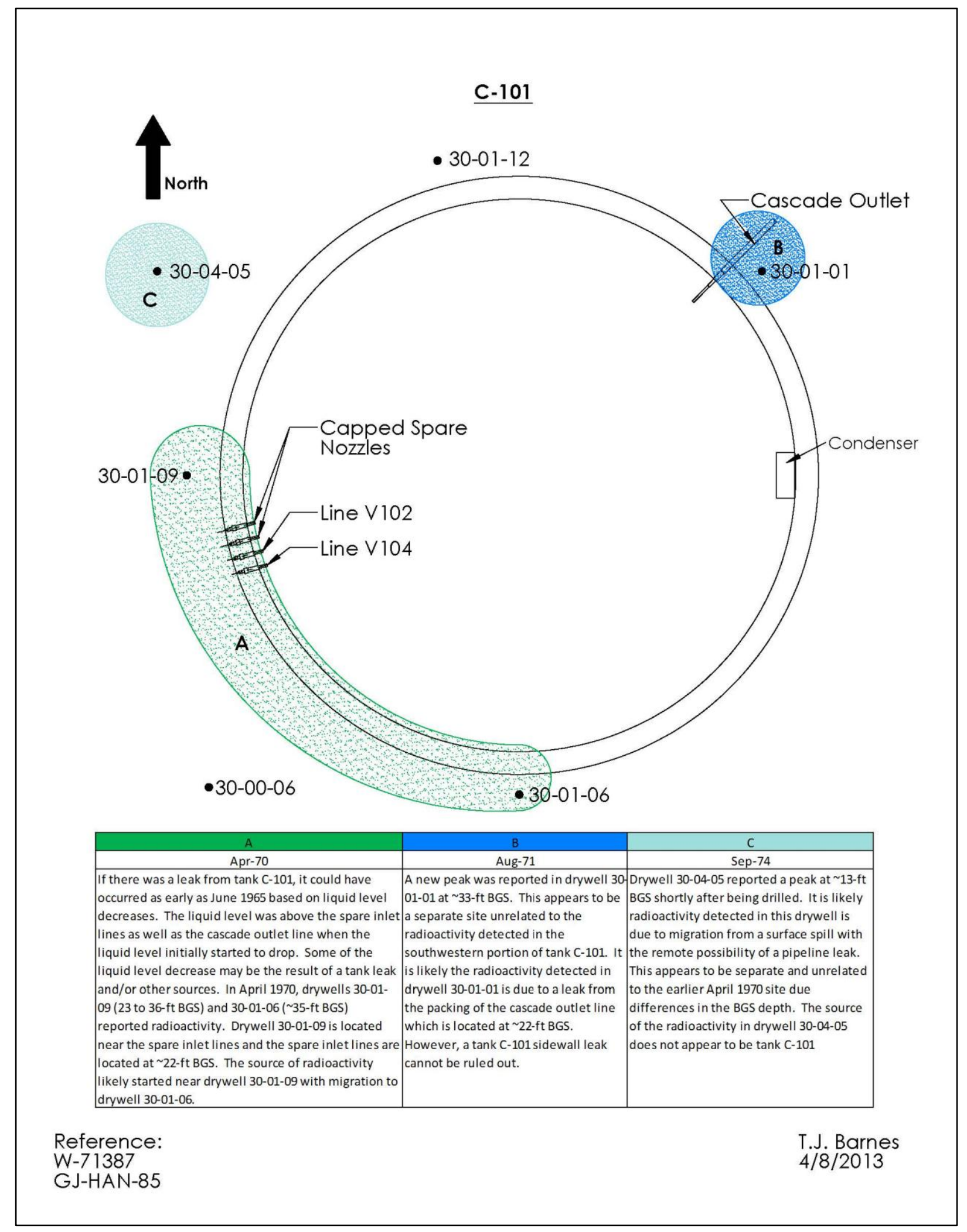


RPP-RPT-54914, Rev. 0

\subsection{POSSIBLE TANK C-101 LINER LEAK CAUSE(S)}

Tank C-101 was examined against five conditions that could contribute to a failed liner.

\subsubsection{Tank Design}

The C Farm tank design does not appear to be a factor contributing to a failed liner (see Section 3.1.1).

\subsubsection{Thermal Conditions}

No temperature data are available for tank C-101 prior to 1972 , however, tank C-101 held only non-boiling waste. Since no records are available, it is uncertain what the maximum temperature was in tank C-101 during operation as well as the rate of temperature rise when waste was initially added. The thermal attributes of the waste and other information (see Section 4.4.2) would indicate that thermal stresses were likely minimal and should not have challenged the tank limits.

Thermal shock creates stress both from rapid temperature rise as well as waste-induced high temperatures which were thought to be minimal.

Temperature requirements in ARH-951 (Limitations for Use of Underground Waste Tanks) issued December 18, 1969 indicated that tank temperatures should be held below $230^{\circ} \mathrm{F}$.

\subsubsection{Chemistry-Corrosion}

Tank C-101 stored MW, TBP, CWP, and PUREX HLW during operation. Tank C-101 stored waste type TBP for approximately nine years total.

TBP Waste consists of low hydroxide, high nitrate, and unknown nitrite concentrations creating an environment conducive to pitting and SCC. A tank with TBP waste type present would likely increase possibility of SCC in the tank liner (see Section 3.2.4 and 4.4.4).

Other wastes stored in tank C-101 should not have resulted in pitting or SCC.

\subsubsection{Liner Observations}

A review of the available photographs for tank C-101 does not contain any evidence pointing to a tank leak. There is no documentation available indicating a liner bulge was present in tank C101.

\subsubsection{Tank Construction Temperature}

The C Farm tank liners were constructed between August 1944 and December 1944. No climatological data is available during that time. However, the time of the year suggests that it is unlikely there would be temperatures low enough to affect the ductile-to-brittle transition temperature. Impact occurrences could have occurred but it is unlikely they would have resulted in fractures due to encountering the ductile-to brittle transition temperature. 


\subsection{TANK C-101 CONCLUSIONS}

Some evidence indicates that the tank C-101 liner may have leaked near the west portion of the tank possibly in the tank sidewall based on the radioactivity in drywell 30-01-09, however, the proximity of the inlet lines could also be a source of drywell 30-01-09 radioactivity. The liquid level analysis points to an inlet line packing leak.

There are several liner leak cause conditions that were examined but the most likely cause of the tank C-101 leak was chemistry-corrosion as it relates to the storage of TBP process wastes. The TBP process waste is conducive to pitting and SCC. Waste chemistry was not controlled to the degree necessary to minimize corrosion when tank C-101 suspected of leaking. There appears to be very little contribution from tank design, construction temperatures, and thermal conditions. However, some or all of the factors can act serially or together to contribute to tank liner failure. 
RPP-RPT-54914, Rev. 0

APPENDIX A1

TANK C-101 GROSS GAMMA DRYWELL DATA

A1-1 
RPP-RPT-54914, Rev. 0

Table 01-1. Tank C-101 Drywell Radioactivity (K counts per minute) (September 1959 through March 1987)

(Drywell Data Sheets Retrieved on March 25, 2013 and SD-WM-TI-356) (2 sheets)

\begin{tabular}{|c|c|c|c|c|c|c|c|c|c|c|c|c|c|c|c|c|}
\hline \multicolumn{3}{|c|}{ 30-01-01 } & \multicolumn{3}{|c|}{ 30-01-06 } & \multicolumn{3}{|c|}{ 30-00-06 } & \multicolumn{3}{|c|}{ 30-01-09 } & \multicolumn{3}{|c|}{ 30-04-05 } & \multicolumn{2}{|c|}{ 30-01-12 } \\
\hline Date & $\begin{array}{c}\text { Peak } \\
(\mathbf{K} \\
\text { cpm) } \\
\end{array}$ & $\begin{array}{c}\text { Depth } \\
\text { (ft) }\end{array}$ & Date & $\begin{array}{c}\text { Peak } \\
(\mathrm{K} \\
\text { cpm) } \\
\end{array}$ & $\begin{array}{c}\text { Depth } \\
\text { (ft) }\end{array}$ & Date & $\begin{array}{c}\text { Peak } \\
\text { (K } \\
\text { cpm) } \\
\end{array}$ & $\begin{array}{c}\text { Depth } \\
\text { (ft) }\end{array}$ & Date & $\begin{array}{c}\text { Peak } \\
(\mathbf{K} \\
\text { cpm })\end{array}$ & $\begin{array}{c}\text { Depth } \\
\text { (ft) }\end{array}$ & Date & $\begin{array}{l}\text { Peak } \\
(\mathrm{K} \\
\text { cpm) } \\
\end{array}$ & $\begin{array}{c}\text { Depth } \\
\text { (ft) }\end{array}$ & Date & $\begin{array}{c}\text { Peak } \\
(\mathrm{K} \\
\text { cpm) } \\
\end{array}$ \\
\hline \multirow{14}{*}{\multicolumn{3}{|c|}{$\begin{array}{c}\text { Drilled March } 1970 \\
\text { First recoverable reading on } \\
\text { May } 11,1970 \\
\text { (see Section } 4.5 .1 .1 \text { ) }\end{array}$}} & \multirow{14}{*}{\multicolumn{3}{|c|}{$\begin{array}{c}\text { Drilled February 6, } 1970 \\
\text { First recoverable reading on } \\
\text { April 7, 1970 } \\
\text { (see Section 4.5.1.2) }\end{array}$}} & $9 / 9 / 1959$ & $<100$ & $\mathrm{~N}^{\prime} \mathrm{A}^{1}$ & \multirow{14}{*}{\multicolumn{3}{|c|}{$\begin{array}{c}\text { Drilled February } 10,1970 \\
\text { First recoverable reading on } \\
\text { April 7, 1970 } \\
\text { (see Section 4.5.1.4) }\end{array}$}} & \multirow{16}{*}{\multicolumn{3}{|c|}{ Drilled July 31, 1974}} & \multirow{14}{*}{\multicolumn{2}{|c|}{ Drilled March 1970}} \\
\hline & & & & & & $9 / 21 / 1960$ & $<100$ & N/A ${ }^{1}$ & & & & & & & & \\
\hline & & & & & & \multirow{3}{*}{$1 / 27 / 1966$} & 6 & 50 & & & & & & & & \\
\hline & & & & & & & 8 & 100 & & & & & & & & \\
\hline & & & & & & & 10 & 134 & & & & & & & & \\
\hline & & & & & & \multirow{3}{*}{$5 / 24 / 1966$} & 8 & 50 & & & & & & & & \\
\hline & & & & & & & 8 & 100 & & & & & & & & \\
\hline & & & & & & & 8 & 133 & & & & & & & & \\
\hline & & & & & & \multirow{3}{*}{$1 / 6 / 1966$} & 6 & 50 & & & & & & & & \\
\hline & & & & & & & 8 & 100 & & & & & & & & \\
\hline & & & & & & & 10 & 134 & & & & & & & & \\
\hline & & & & & & \multirow{3}{*}{$11 / 4 / 1966$} & 5 & 50 & & & & & & & & \\
\hline & & & & & & & 7 & 100 & & & & & & & & \\
\hline & & & & & & & 8 & 133 & & & & & & & & \\
\hline 7/31/1972 & 31.7 & 39 & 7/31/1972 & 99.7 & 78 & & $\mathrm{~N} / \mathrm{A}^{1}$ & & $7 / 31 / 1972$ & 996.4 & 30 & & & & $7 / 31 / 1972$ & $<6$ \\
\hline $9 / 24 / 1973$ & 16.6 & 39 & $6 / 18 / 1973$ & 53.5 & 76 & & N/A ${ }^{1}$ & & $10 / 8 / 1973$ & 843.6 & 29 & & & & N/A ${ }^{1}$ & \\
\hline $7 / 25 / 1974$ & 10 & 40 & $7 / 25 / 1974$ & 22.4 & 75 & & N/A ${ }^{1}$ & & $8 / 1 / 1974$ & 959 & 30 & 9/9/1974 & 28.6 & 13 & $7 / 25 / 1974$ & $<6$ \\
\hline $12 / 20 / 1974$ & 9.1 & 40 & $12 / 20 / 1974$ & 16 & 76 & & $\mathrm{~N}^{\prime} \mathrm{A}^{1}$ & & $12 / 20 / 1974$ & 921.4 & 28 & $12 / 20 / 1974$ & 27.3 & 14 & $12 / 20 / 1974$ & $<3$ \\
\hline \multirow{2}{*}{$6 / 26 / 1975$} & \multirow{2}{*}{7.4} & \multirow{2}{*}{38} & \multirow{2}{*}{$6 / 26 / 1975$} & \multirow{2}{*}{14.7} & \multirow{2}{*}{75} & \multirow{2}{*}{\multicolumn{3}{|c|}{ N/A ${ }^{1}$}} & \multirow{2}{*}{$6 / 26 / 1975$} & \multirow{2}{*}{1017.2} & \multirow{2}{*}{28} & $1 / 24 / 1975$ & 28.8 & 13 & $6 / 26 / 1975$ & $<3$ \\
\hline & & & & & & & & & & & & $1 / 24 / 19 / 3$ & 3 & 22 & $0 / 20 / 1913$ & -5 \\
\hline & N/A ${ }^{1}$ & & & N/A ${ }^{1}$ & & & N/A ${ }^{1}$ & & & N/A ${ }^{1}$ & & 7/7/1975 & 2.7 & 23 & N/A ${ }^{1}$ & \\
\hline $2 / 27 / 1976$ & 6.8 & 36 & $2 / 27 / 1976$ & 9.4 & 74 & & N/A ${ }^{1}$ & & $2 / 27 / 1976$ & 863.1 & 26 & $2 / 27 / 1976$ & $<3$ & N/A ${ }^{1}$ & $2 / 27 / 1976$ & $<3$ \\
\hline 4/1/1977 & 4 & 37 & 4/1/1977 & 5.1 & 74 & & N/A ${ }^{1}$ & & 4/1/1977 & 929.1 & 26 & $4 / 1 / 1977$ & $<3$ & N/A ${ }^{1}$ & $4 / 1 / 1977$ & $<3$ \\
\hline $4 / 7 / 1978$ & 3.3 & 36 & 4/7/1978 & 4.2 & 74 & & $\mathrm{~N} \mathrm{~A}^{1}$ & & 4/7/1978 & 855.2 & 26 & 4/7/1978 & $<3$ & $\mathrm{~N}^{\prime} \mathrm{A}^{1}$ & 4/7/1978 & $<3$ \\
\hline & N/A ${ }^{1}$ & & $5 / 4 / 1978$ & 3.1 & 74 & & N/A ${ }^{1}$ & & & $\mathrm{~N} / \mathrm{A}^{1}$ & & & $\mathrm{~N} / \mathrm{A}^{1}$ & & $\mathrm{~N} / \mathrm{A}^{1}$ & \\
\hline & & & שר הודית & 3.2 & 34 & & & & & & & & & & & \\
\hline & N/A ${ }^{1}$ & & $9 / 15 / 1978$ & $<3$ & 74 & & $\mathrm{~N} / \mathrm{A}^{1}$ & & & N/A ${ }^{1}$ & & & $\mathrm{~N} / \mathrm{A}^{1}$ & & $\mathrm{~N} / \mathrm{A}^{1}$ & \\
\hline & 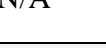 & & סוצונהות & 3.4 & 34 & & $1 \mathrm{~V} / \mathrm{A}$ & & & 1 18 & & & 政 & & 政 & \\
\hline 4/11/1979 & 3 & 36 & 4/11/1979 & 4.9 & 34 & & N/A ${ }^{1}$ & & 4/11/1979 & 879 & 26 & $4 / 11 / 1979$ & $<3$ & $\mathrm{~N}^{\prime} \mathrm{A}^{1}$ & 4/11/1979 & $<3$ \\
\hline $4 / 9 / 1980$ & 3 & 36 & $1 / 3 / 1980$ & 7.7 & 34 & & N/A ${ }^{1}$ & & 4/8/1980 & 874 & 26 & $4 / 8 / 1980$ & $<3$ & N/A ${ }^{1}$ & $4 / 9 / 1980$ & $<3$ \\
\hline
\end{tabular}

A1-2 
RPP-RPT-54914, Rev. 0

\begin{tabular}{|c|c|c|c|c|c|c|c|c|c|c|c|c|c|c|c|c|}
\hline \multicolumn{3}{|c|}{ 30-01-01 } & \multicolumn{3}{|c|}{ 30-01-06 } & \multicolumn{3}{|c|}{ 30-00-06 } & \multicolumn{3}{|c|}{ 30-01-09 } & \multicolumn{3}{|c|}{ 30-04-05 } & \multicolumn{2}{|c|}{ 30-01-12 } \\
\hline Date & $\begin{array}{c}\text { Peak } \\
(\mathrm{K} \\
\text { cpm) } \\
\end{array}$ & $\begin{array}{c}\text { Depth } \\
\text { (ft) }\end{array}$ & Date & \begin{tabular}{|c|} 
Peak \\
$(\mathrm{K}$ \\
cpm) \\
\end{tabular} & $\begin{array}{c}\text { Depth } \\
\text { (ft) }\end{array}$ & Date & $\begin{array}{c}\text { Peak } \\
(\mathrm{K} \\
\text { cpm) } \\
\end{array}$ & $\begin{array}{c}\text { Depth } \\
\text { (ft) }\end{array}$ & Date & \begin{tabular}{|c|} 
Peak \\
$(\mathrm{K}$ \\
cpm $)$
\end{tabular} & $\begin{array}{l}\text { Depth } \\
\text { (ft) }\end{array}$ & Date & $\begin{array}{c}\text { Peak } \\
(\mathrm{K} \\
\text { cpm })\end{array}$ & $\begin{array}{c}\text { Depth } \\
\text { (ft) }\end{array}$ & Date & $\begin{array}{c}\text { Peak } \\
(\mathrm{K} \\
\text { cpm) }\end{array}$ \\
\hline \multicolumn{3}{|c|}{ N/A ${ }^{1}$} & $4 / 9 / 1980$ & 7.7 & 35 & \multicolumn{3}{|c|}{ N/A ${ }^{1}$} & \multicolumn{3}{|c|}{$\mathrm{N} / \mathrm{A}^{1}$} & \multicolumn{3}{|c|}{ N/A ${ }^{1}$} & \multicolumn{2}{|c|}{$\mathrm{N} / \mathrm{A}^{1}$} \\
\hline $4 / 16 / 1981$ & 2.4 & 36 & $4 / 8 / 1981$ & 7.6 & 35 & & N/A ${ }^{1}$ & & $3 / 25 / 1981$ & 840.2 & 27 & $4 / 8 / 1981$ & $<3$ & $\mathrm{~N} / \mathrm{A}^{1}$ & $4 / 8 / 1981$ & $<3$ \\
\hline $4 / 23 / 1982$ & 2.3 & 37 & $4 / 7 / 1982$ & 6.9 & 35 & & N/A ${ }^{1}$ & & $4 / 7 / 1982$ & 768.7 & 25 & $4 / 22 / 1982$ & $<3$ & N/A ${ }^{1}$ & $4 / 7 / 1982$ & $<3$ \\
\hline $2 / 23 / 1983$ & 2 & 39 & $3 / 10 / 1983$ & 5.6 & 37 & & $\mathrm{~N} / \mathrm{A}^{1}$ & & $3 / 10 / 1983$ & 1223.9 & 28 & $3 / 24 / 1983$ & $<3$ & N/A ${ }^{1}$ & $3 / 10 / 1983$ & $<3$ \\
\hline \multicolumn{3}{|c|}{$\mathrm{N} / \mathrm{A}^{1}$} & $6 / 23 / 1983$ & 5.5 & 36 & & $\mathrm{~N} / \mathrm{A}^{1}$ & & $6 / 23 / 1983$ & 852.8 & 28 & \multicolumn{3}{|c|}{$\mathrm{N} / \mathrm{A}^{1}$} & $6 / 23 / 1983$ & $<3$ \\
\hline $3 / 20 / 1984$ & 2.3 & 39 & $6 / 13 / 1984$ & 5.8 & 37 & & N/A ${ }^{1}$ & & $6 / 14 / 1984$ & 806.2 & 28 & $4 / 4 / 1984$ & $<3$ & $\mathrm{~N} / \mathrm{A}^{1}$ & $6 / 14 / 1984$ & $<3$ \\
\hline \multicolumn{3}{|c|}{ N/A ${ }^{1}$} & $6 / 14 / 1984$ & 5.5 & 36 & & $\mathrm{~N} / \mathrm{A}^{1}$ & & \multicolumn{3}{|c|}{$\mathrm{N} / \mathrm{A}^{1}$} & \multicolumn{3}{|c|}{$\mathrm{N} / \mathrm{A}^{1}$} & \multicolumn{2}{|l|}{$\mathrm{N} / \mathrm{A}^{1}$} \\
\hline $3 / 20 / 1985$ & 2.5 & 40 & $4 / 18 / 1985$ & 7.1 & 37 & \multicolumn{3}{|c|}{ N/A ${ }^{1}$} & $4 / 18 / 1985$ & 845.2 & 29 & $4 / 3 / 1985$ & $<3$ & $\mathrm{~N} / \mathrm{A}^{1}$ & $4 / 3 / 1985$ & $<3$ \\
\hline $1 / 20 / 1986$ & 2.3 & 39 & $6 / 11 / 1985$ & 6.6 & 37 & \multicolumn{3}{|c|}{ N/A ${ }^{1}$} & $6 / 13 / 1985$ & 852.7 & 29 & $3 / 7 / 1986$ & $<3$ & $\mathrm{~N} / \mathrm{A}^{1}$ & $3 / 6 / 1986$ & $<3$ \\
\hline $3 / 18 / 1986$ & $<3$ & N/A ${ }^{1}$ & $6 / 18 / 1986$ & 6.4 & 38 & \multicolumn{3}{|c|}{$\mathrm{N} / \mathrm{A}^{1}$} & $6 / 18 / 1986$ & \begin{tabular}{|l|}
701.4 \\
\end{tabular} & 29 & \multicolumn{3}{|c|}{ N/A ${ }^{1}$} & \multicolumn{2}{|l|}{$\mathrm{N} / \mathrm{A}^{1}$} \\
\hline $3 / 17 / 1987$ & $<3$ & N/A ${ }^{1}$ & \multicolumn{3}{|c|}{$\mathrm{N} / \mathrm{A}^{1}$} & & $\mathrm{~N} / \mathrm{A}^{1}$ & & \multicolumn{3}{|c|}{$\mathrm{N} / \mathrm{A}^{1}$} & $2 / 4 / 1987$ & $<3$ & N/A ${ }^{1}$ & $2 / 5 / 1987$ & $<3$ \\
\hline
\end{tabular}


RPP-RPT-54914, Rev. 0

\section{APPENDIX B1}

DETAILED TANK C-101 LIQUID LEVEL ANALYSIS

B1-1 


\section{Detailed Tank C-101 Liquid Level Analysis}

The tank C-101 liquid level (LL) data from September 30, 1965 to August 25, 2010 was analyzed in detail. The bulk of the data points for review of the historical LL decrease (1965 1969) were in volumetric form from half yearly and quarterly reports. The LL's for the historical period are calculated from the tank waste volumes. This could result in a fairly large relative discrepancy when the transition was made to actual LL from data sheets at September 30, 1973. The dates were set at mid-month of the last month in the period for plotting purposes and to line up with description of the timing in RHO-CD-896. A 1973 - 1980 series of C-Farm LL data sheets, Accession \# 1007140243 and data plots was found which provided detailed LLs for that seven year period. PCSACS contains waste levels from 1981 with ENRAF measurements at the opposite side of the tank from 2002 to the present.

Four tank C-101 LL periods were reviewed as follows (see Figure 01-1):

1. June 30, 1965 to December 15, 1969

2. December 30, 1969 to August 15, 1974

3. August 15, 1974 to June 30, 1980

4. January 5, 1981 to August 25, 2010

Figure 01-1. Tank C-101 LL 1964 - 2010

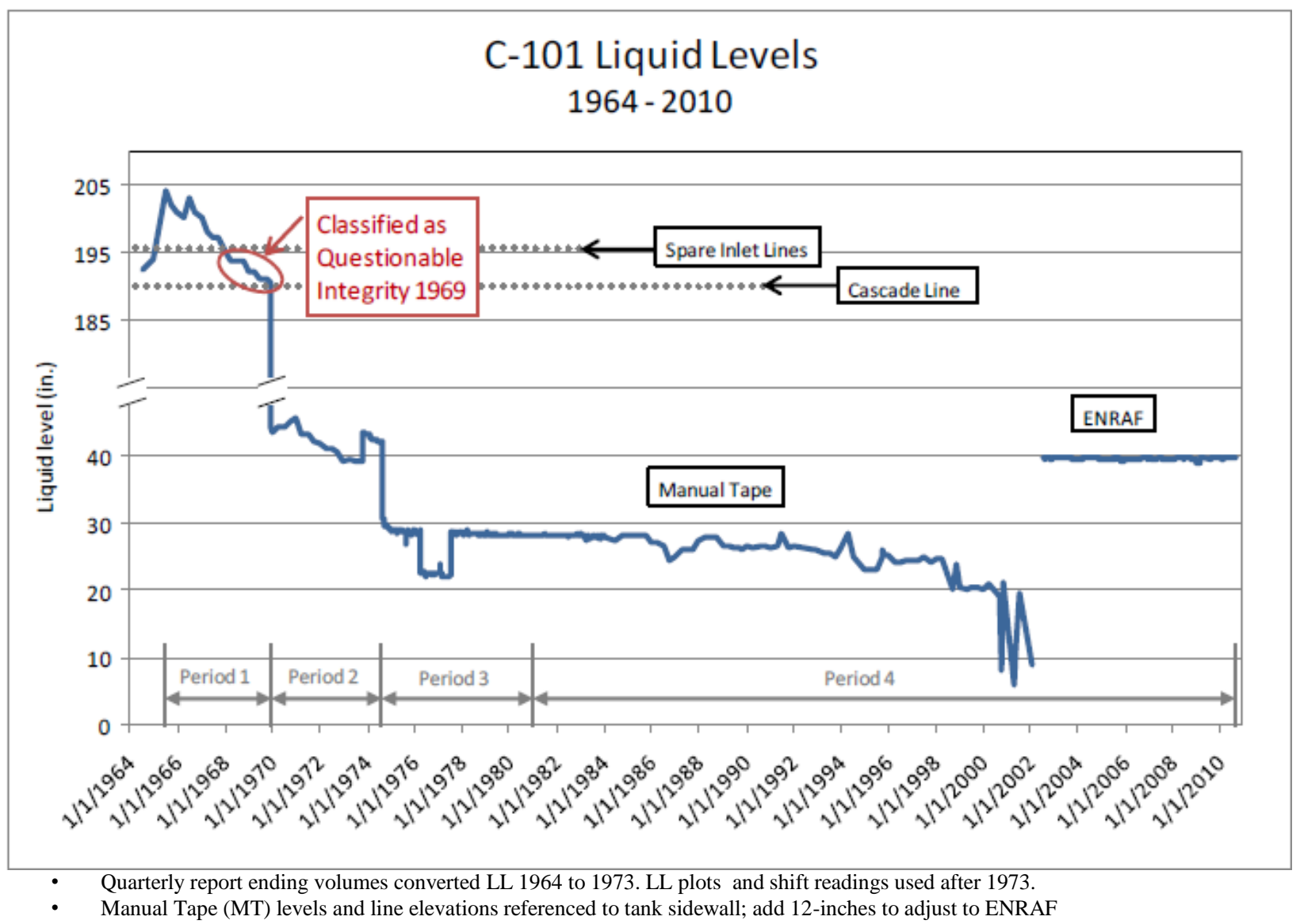


RPP-RPT-54914, Rev. 0

\section{B1.1 Period 1, June 30, 1965 to December 15, 1969}

Discussion of the period includes the 23 months (100 weeks), addressed in RHO-CD-896, which occurred before the ending of the period, described as approximately the period before December 1969 when the tank was pumped to tank C-105.

\section{B1.1.1 The 23 months (100 weeks) before the end of the period}

Document RHO-CD-896 reports a 4 inch (11,000 gallon) decrease in liquid level from 194.5 inches to 190.5 inches ( 536,000 gallons) in $\sim 23$ months between "approximately" January 1968 and December 1969. The cascade line starts to overflow at $\sim 535,000$ gal. The resulting liquid level decrease rate for 23 months is $\sim 110$ gallons per week. This liquid level decrease resulted in tank C-101 being declared of questionable integrity in 1969 and being reviewed in the 1980 RHO-CD-896 document. The recommendation in RHO-CD-896 was to reclassify tank C-101 as a confirmed leaker based primarily on the 23 month decrease with some mostly inconclusive drywell data.

There was no information found to pinpoint the exact dates of the liquid level decrease so December 15, 1969 was selected as the ending date. This date will also be used as the ending date for the entire period. The volume at the end of the quarter in ARH-1200D indicated the tank had been pumped by December 31, 1969. The beginning of the $\sim 23$ month segment was then set at January 15, 1968. Both of these dates fit into the information found in RHO-CD-896 indicated above. The volume of the ending liquid level was calculated using the volume calculator in internal letter, H. N. Raymond to C. J. Francis, August 21, 1972, Maximum Operating Levels and Cascade Levels in 200 - West Area Tank Farms. The letter states on page 5 that, "Tank Farms B, C, T, and U volumes are computed as follows: Volume $=$ (tape reading $\mathrm{x}$ 2750 gal/in $)+12,500$ gal". The December 15, 1969 volume is then, $(190.5$ inches $x 2,750$ gallons/inch $)+12,500$ gallons $=536,375$ gallons, rounded to 536,000 gallons. Even though later tank volume calculators do not exactly duplicate these volumes, the date of the letter, 1972, indicates that this formula was probably used during the period in question. The formula was confirmed to have been used as late as 1980 in RHO-CD-896, page 76, for the then current tank T-111 volume (488,000 gallons) and manual tape reading (173 inches) which verified use of the formula. All half yearly and quarterly report ending volumes were calculated with this formula.

\section{B1.1.2 The entire period, June 30, 1965 to December 15, 1969}

The volume of waste in tank C-101 at the beginning of the first period is found in RL-SEP-659 on page 4 as 574,000 gallons on June 30, 1965, which is well above the cascade line and the two capped spare inlet lines. A previous document, HW-83308, recorded a volume also above the cascade line and the capped spare inlet lines for June 30, 1964 of 542,000 gallons; however, the later much larger increased volume of 574,000 gallons was used for an initial calculation of the volume decrease rate. In addition material balances between quarterly report data indicated that there was little if any decrease until reaching the highest level. The maximum volume decrease for the entire period was therefore 574,000 gallons $-536,000$ gallons (from above) $=38,000$ gallons over the 232 week period for a linear liquid volume decrease rate of 164 gallons per 
week. This disregarded the possible effects of a new manual tape (MT) that was installed before June 30, 1966 (ISO-404).

The first four quarterly volumes including the initial high at 574,000 gallons were considered separately when a comparison was made with the new MT data starting with June 30, 1966. No transfers were reported in this one year period, however for some unexplained reason the MT was changed out. The overall revised initial segment from June 30, 1966 to January 15, 1968 provided a linear waste volume decrease of 258 gallons/week with an interesting reduction in the rate at the approximate level of the spare inlet lines (see Figure 01-2). This could mean that the spare inlet lines were leaking at a rate of about 150 gallons/week ( $28 \mathrm{ml} / \mathrm{min}$ each) if the following segment at 108 gallons/week was attributed to only the cascade line (seepage to tank C-102 or leakage through the packing) and the effects of reduced head and other parameters were disregarded.

Figure 01-2. Tank C-101 LL 6/30/1965 - 9/30/1969

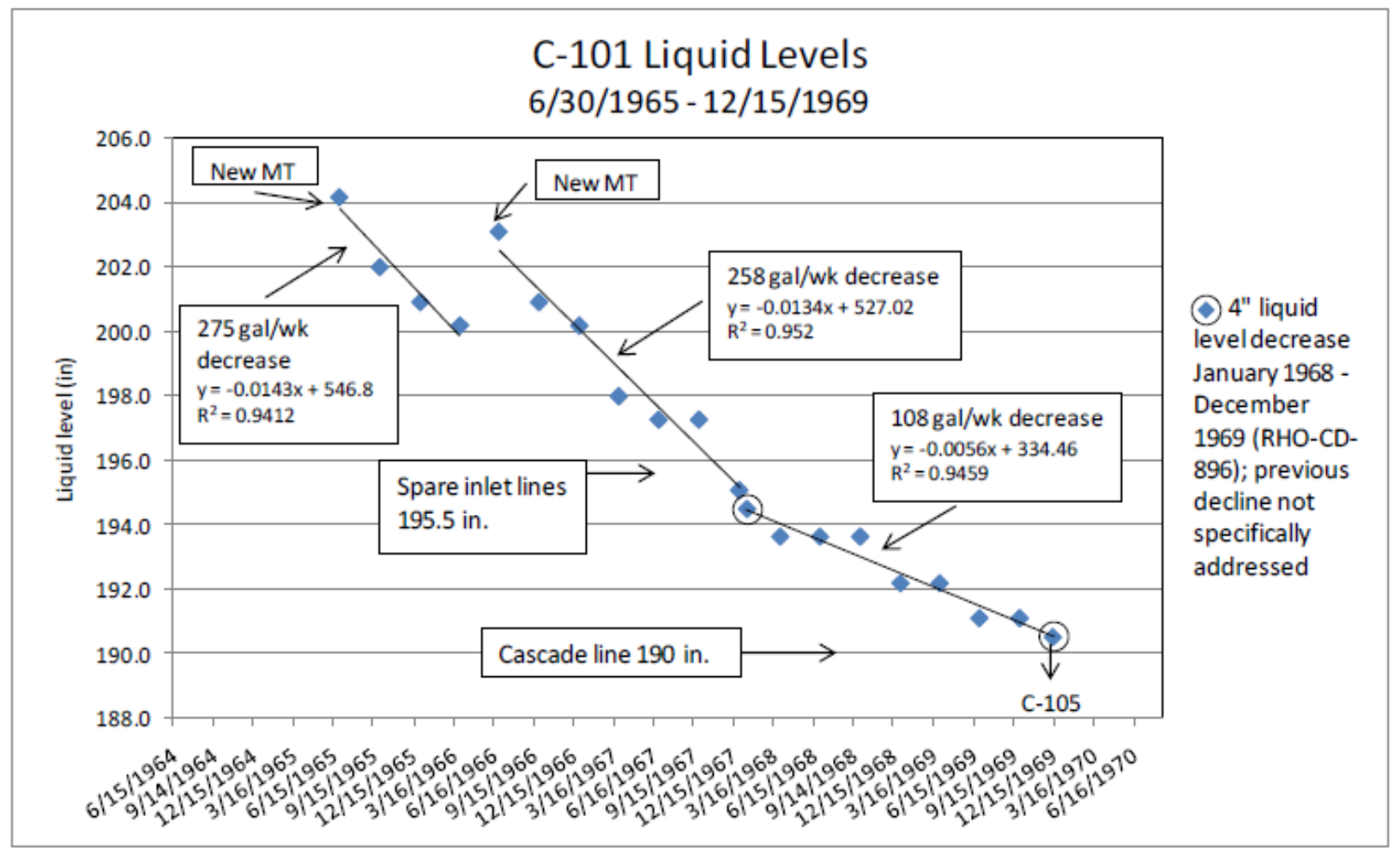

Note: MT levels and line elevations referenced to the tank sidewall; add 12-inches to adjust to current waste levels.

A separate curve was developed (Figure 01-3) to explore a potentially decreasing rate scenario that may be possible with a reduction in head above spare inlet line leakage and some flow through a partially plugged cascade line. The cascade line was reported to be partially plugged in June 1954 (HW-32389) and up to the second quarter 1956 (RHO-LD-79), however, there is no record that waste cascaded from tank $\mathrm{C}-101$ to tank $\mathrm{C}-102$ during the review time period. A review of the tank C-102 liquid level in WHC-SD-WM-ER-349 and attendant quarterly reports for the period indicated there were numerous transfers in and out of tank C-102 which could mask any slow seepage through a partially plugged cascade line from tank C-101. Not to be 
ruled out at this point is the possibility of a tank leak, and vapor escaping from the atmospheric condenser.

The Cs-137 content of the waste in tank C-101 at the LL of $\sim 204$ inches provided the potential for evaporation of $\sim 2,550$ gallons/ month assuming no heat losses to the tank structure or surrounding soil, RPP-ENV-33418, Rev. 1, or reduction with decreasing LL. The condensers were reported to be "adequate for the waste temperatures and vapor loads encountered in original operations (Approximately $180{ }^{\circ} \mathrm{F}\left(82^{\circ} \mathrm{C}\right)$ for sludge and supernatants)", WHC-MR-0132. There is no direct tank C-101 temperature information available for this time frame. RPP-ENV-33418, Rev. 1, contains temperature ranges of the waste from the source tanks which indicates that tank C-101 waste may have been near the point where the condenser may not have been $100 \%$ adequate. An estimate of $95 \%$ efficient was postulated for the atmospheric condensers which may not have produced significant ground contamination but would result in $\sim 128$ gallons/month $(11 \mathrm{ml} / \mathrm{min})$ of water as a vapor escaping into the atmospheric. This would diminish with the reduction in the LL as the supernatant with cesium was decreasing. This by no means comes close to the point experienced in other tank farm condenser operations where contaminated water was actually ejected from the condenser and contaminated the surrounding ground. However, it can be assumed some water vapor probably escaped the atmospheric condensers.

Figure 01-3. Tank C-101 LL June 30, 1966 to December 15, 1969

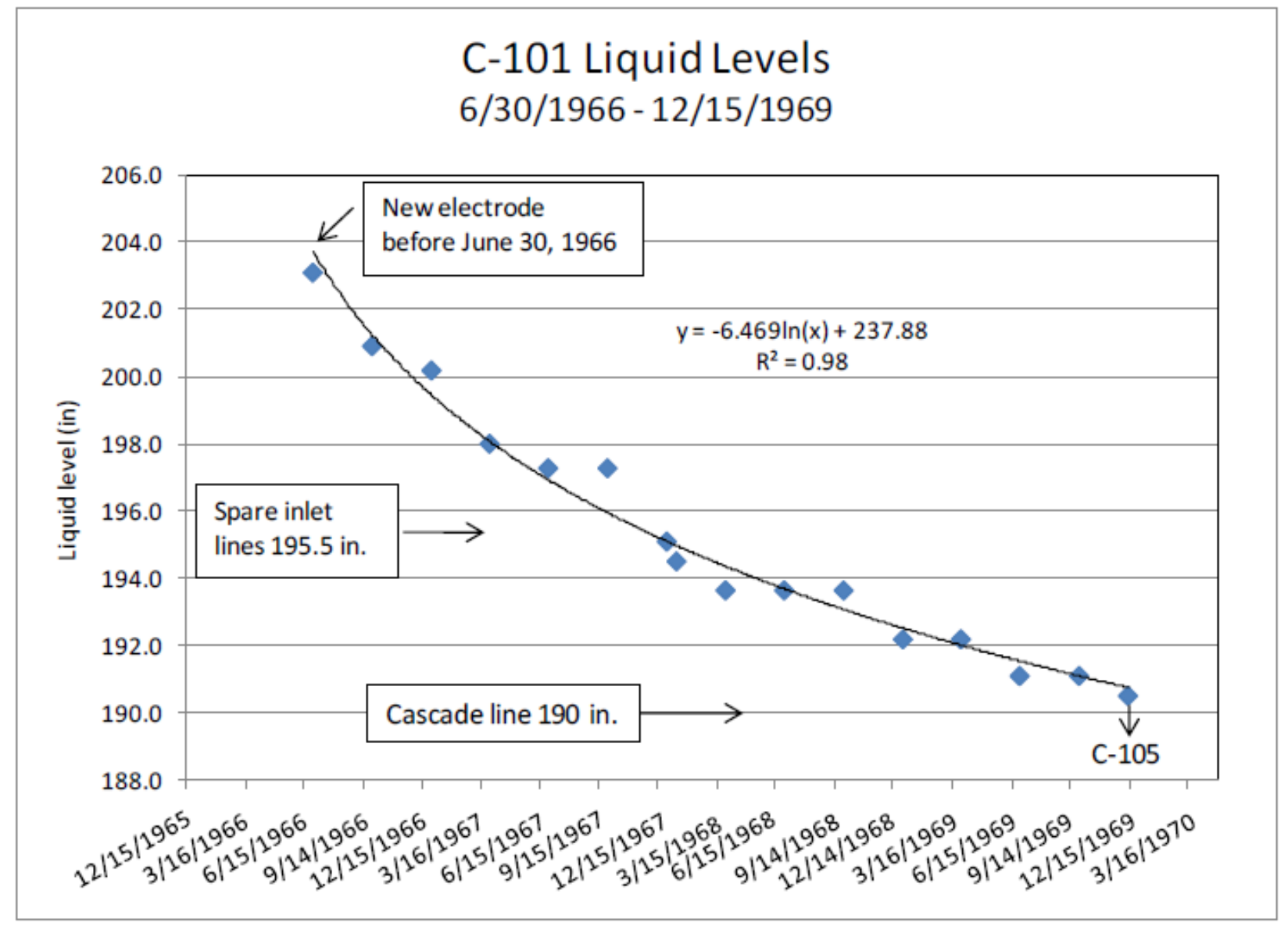

Note: MT levels and line elevations referenced to the tank sidewall; add 12-inches to adjust to current waste levels. 
A projection of the curve in Figure 01-4 after pumping to tank C-105 was made to determine the possible termination of what appears to be a decreasing rate. Four nonlinear regression models were fitted to the waste height data from tank C-101 from the time period of June 30, 1966 through December 15, 1969. Three of the fitted models project that the waste height would have reached a stable level of approximately 188 inches around 1973. Although these three models appear to fit the data well, two of the three models have an extremely large uncertainty in the future projections, rendering them not useful. The fourth model predicts that the waste height would continue to decline, although at a slowing rate. For the two useful models, there is little to suggest picking one model over the other (Figure 01-4) as the performance relative to the confidence levels are similar. This suggests that the choice of one model over the other would be based more on the reasonableness of match to other technical considerations, rather than statistical considerations.

\section{Figure 01-4. Tank C-101 1969 Projected LL Decrease}

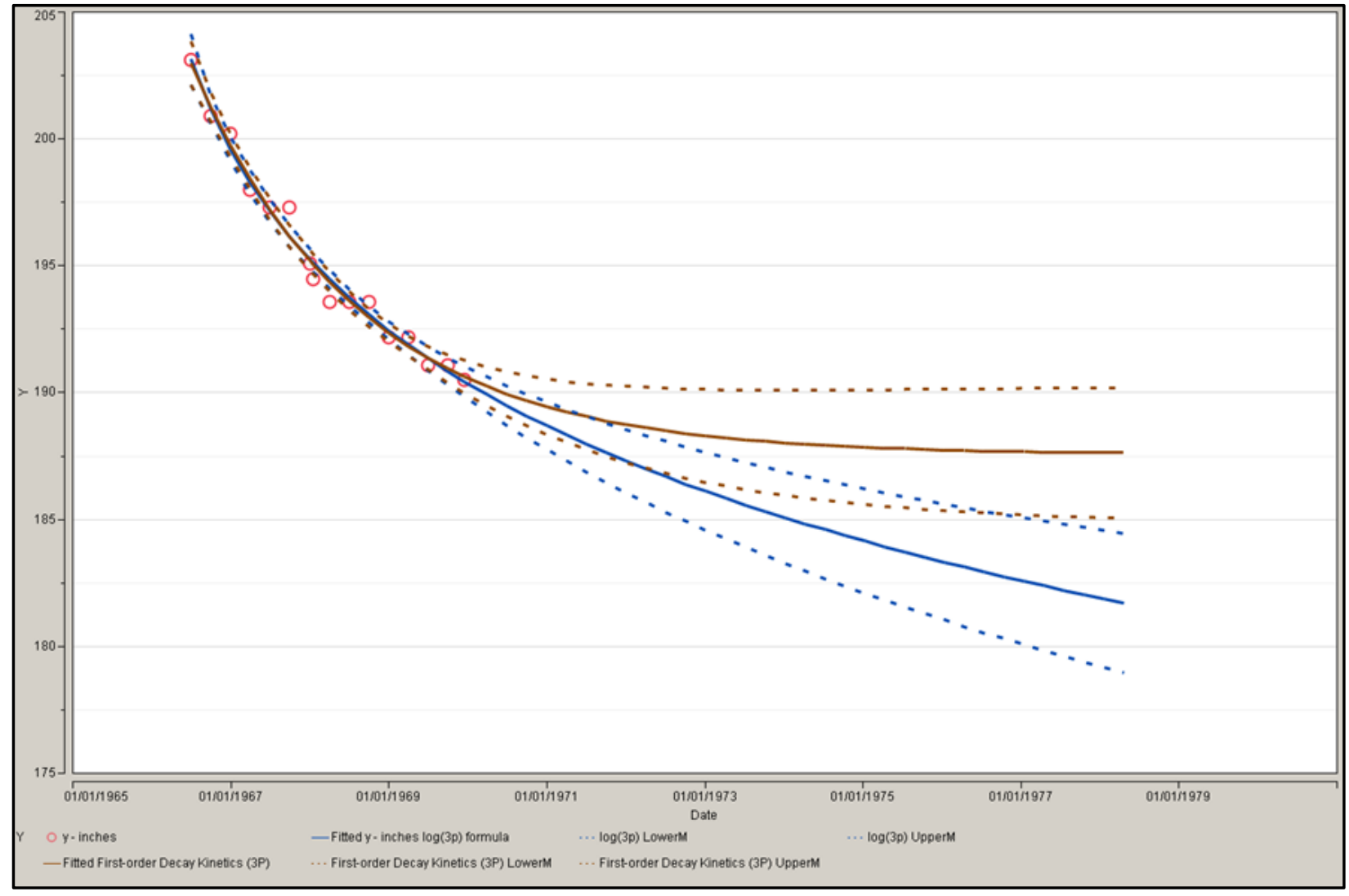


RPP-RPT-54914, Rev. 0

\section{B1.1.3 Conclusion}

The above discussion indicates that the previously reported partially plugged cascade line could be seeping to tank C-102 or leaking through the packing, or potentially leaking through two capped spare inlet lines or packing of the two active inlet lines, or possible water vapor exiting the atmospheric condenser, or a tank leak were gradually causing the liquid level to decrease at what may be a declining rate as the liquid level decreased at least to the level of the cascade line. A decreasing rate could be a result of the reduction in head above the cascade line, spare inlet lines or a tank leak location as well as the reduction in heat content resulting in a more effective atmospheric condenser. The possible decreases from the cascade line and spare inlet lines would be eliminated when the liquid level decreased below these two points. Evaporation past the condenser and condenser gasket leakage could have continued but at a much lesser degree when the tank waste was pumped.

\section{B1.2 Period 2, December 30, 1969 to August 15, 1974}

The December 30, 1969 to August 15, 1974 period starts with pumping tank C-101 to tank C105 and ends with pumping to tank C-104 (see Figure 01-5). Quarterly report LL data was used to plot the tank C-101 LL until the new MT was installed October 15, 1973. The LL plot after that time used data from C Tank Farm Liquid Level Readings Data Sheets dayshift entries. The period begins with an unexplained volume increase over four quarterly report periods from 43.5 inches to 45.6 inches on December 30, 1970 (see Figure 01-5). The waste volume abruptly decreased to 43.1 inches in the next quarterly report, March 31, 1970; no explanation was found for the decrease. This appears to be a pattern similar to installation of a new MT. A waste volume then decreased from 43.1 inches, on March 31, 1970 to 39.1 inches on September 30, 1973, after which time a new tape was installed October 15, 1973 and the reading returned to the original 43.1 inches indicating that there may have been no decrease in liquid level. The possibility exists that the 43.5 inches of LL at the end of pumping, December 30, 1970, may not be a true reading when viewed with the unexplained subsequent increases and decrease to 43.1 inches with collaborating return to nearly the same 43.1 inch LL more than two years later with a new MT October 15, 1973. The later LL remained steady for more than four months when a new MT was installed February 8, 1974 which indicated a 1/2-in. decrease from the four month steady period. The base line was decreased $1 / 2$-in. five days later without explanation and the tank was pumped to tank C-104 February 15, 1974 after another unexplained decrease of 1/2-in. over two separate time frames. It should also be noted the MT was replaced multiple times during this period which could account for these LL discrepancies.

The Tank Farm Surveillance (TFS) Group reported in RHO-CD-896 that the 1970 - 1973 decrease along with the 4 inch decrease, 1968-1969, were two periods associated with a tank leak. The TFS Group entry did not mention the return to the original volume for this period in spite of the fact it was acknowledged elsewhere in the report. None of the other three contributors to the report acknowledged this specific decrease. The graph in RHO-CD-896, page 49 shows the liquid level decrease with the new tape and return to approximately the original reading with installation of new tape. RHO-CD-896 page 8 Item 7 also indicates that this was a sludge decrease in spite of the information in RHO-LD-79, March 1979, which indicated a constant 81,000 gallons of sludge during the period. A letter from G.T. Dukelow (TFPC) to W.W. Schulz (Chief Scientist) January 11, 1980, Reevaluation of Tanks Classified as Being of 
Questionable Integrity indicated that the estimated leakage volume was "approximately 10,000 gallons based on LL decrease from the 194 inch level", with no mention of the alleged decrease March 31, 1970 to June 30, 1973. The TFPC entry in RHO-CD-896 stated, "The volume of liquid estimated to have leaked from Tank 101-C is 10,000 to 24,000 gallons." The final edited and approved document January 25, 1980 (two weeks later) did not include the letter statement or an explanation of the difference.

Figure 01-5. Tank C-101 LL September 30, 1969 to August 15, 1974

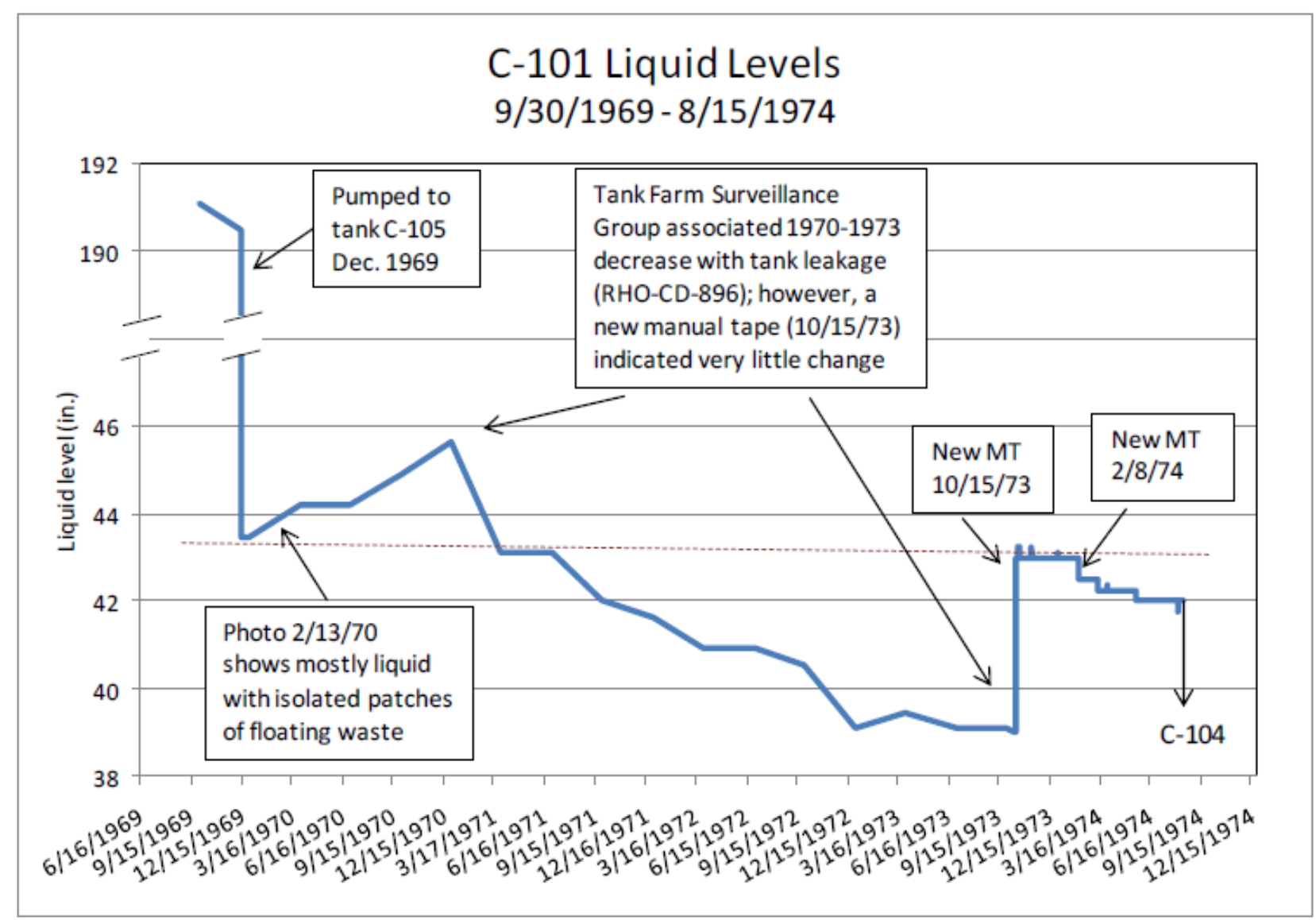

Note: Tank Farm Liquid Level Readings from Data Sheet starts at the new MT on 10/15/73

Note: MT levels and line elevations referenced to tank sidewall; add 12-inches to adjust to ENRAF

Photos of the waste surface February 131970 indicates a mostly liquid surface with isolated small patches of floating waste (Figure 01-6). 
RPP-RPT-54914, Rev. 0

Figure 01-6. Tank C-101 Photograph February 13, 1970 (700695-20)

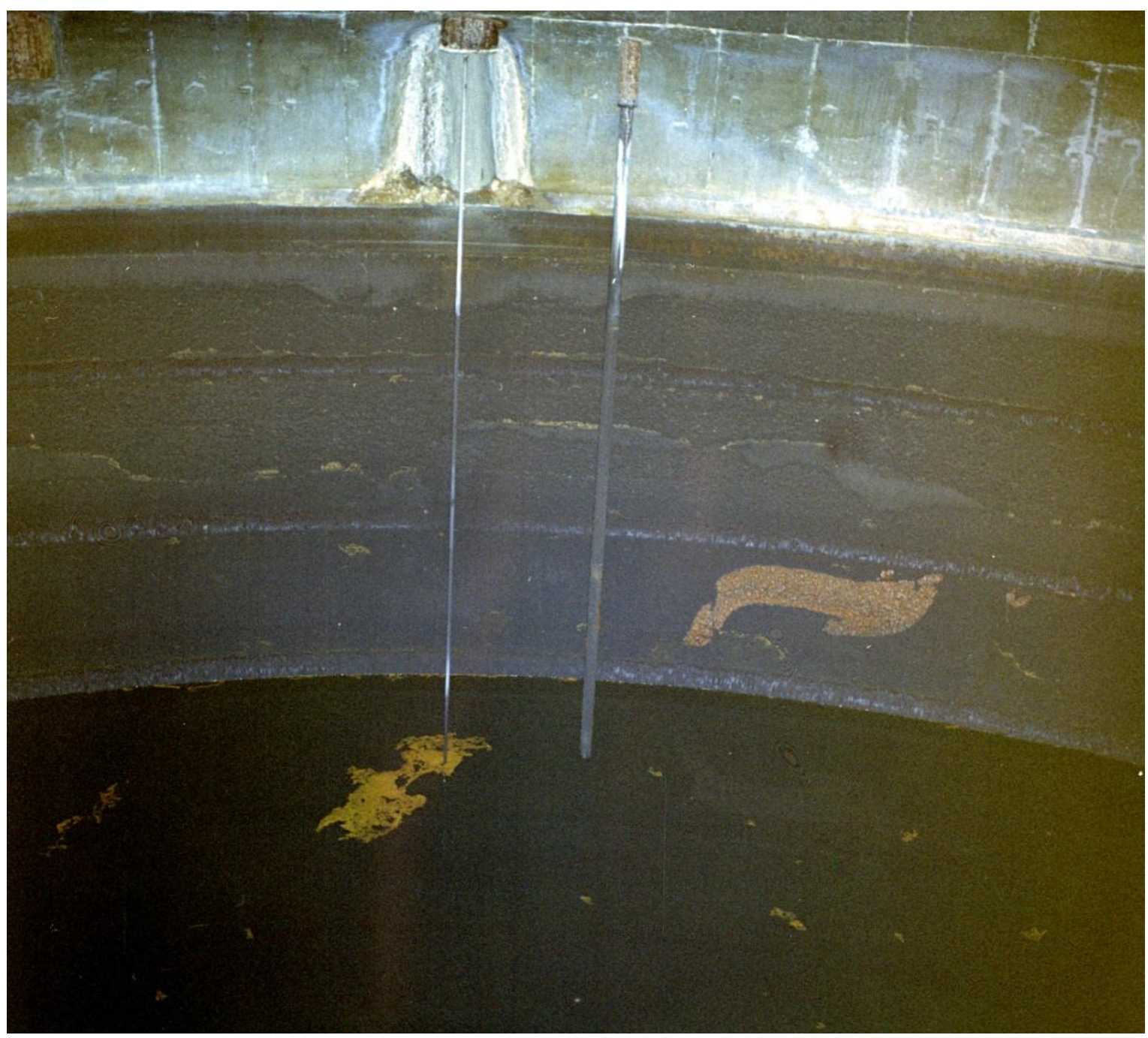

\section{B1.2.1 Conclusion}

There appears to be very little evidence to support a tank leak in the December 30, 1969 to August 15, 1974 period. 


\section{B1.3 Period 3, August 15, 1974 to June 30, 1980}

Tank Farm Liquid Level Readings Data Sheets and graphs covering C-Farm tank LLs are available for the July 1, 1974 to June 30, 1980 (see Figure 01-7). There is very little if any decrease in liquid level that cannot be explained by a change-out of the manual tape or the manual tape resting on reported "salt cake". The rate of decrease after salt well pumping is 0.11in/yr.

Figure 01-7. Tank C-101 LL 8/15/1973 - 6/30/1980

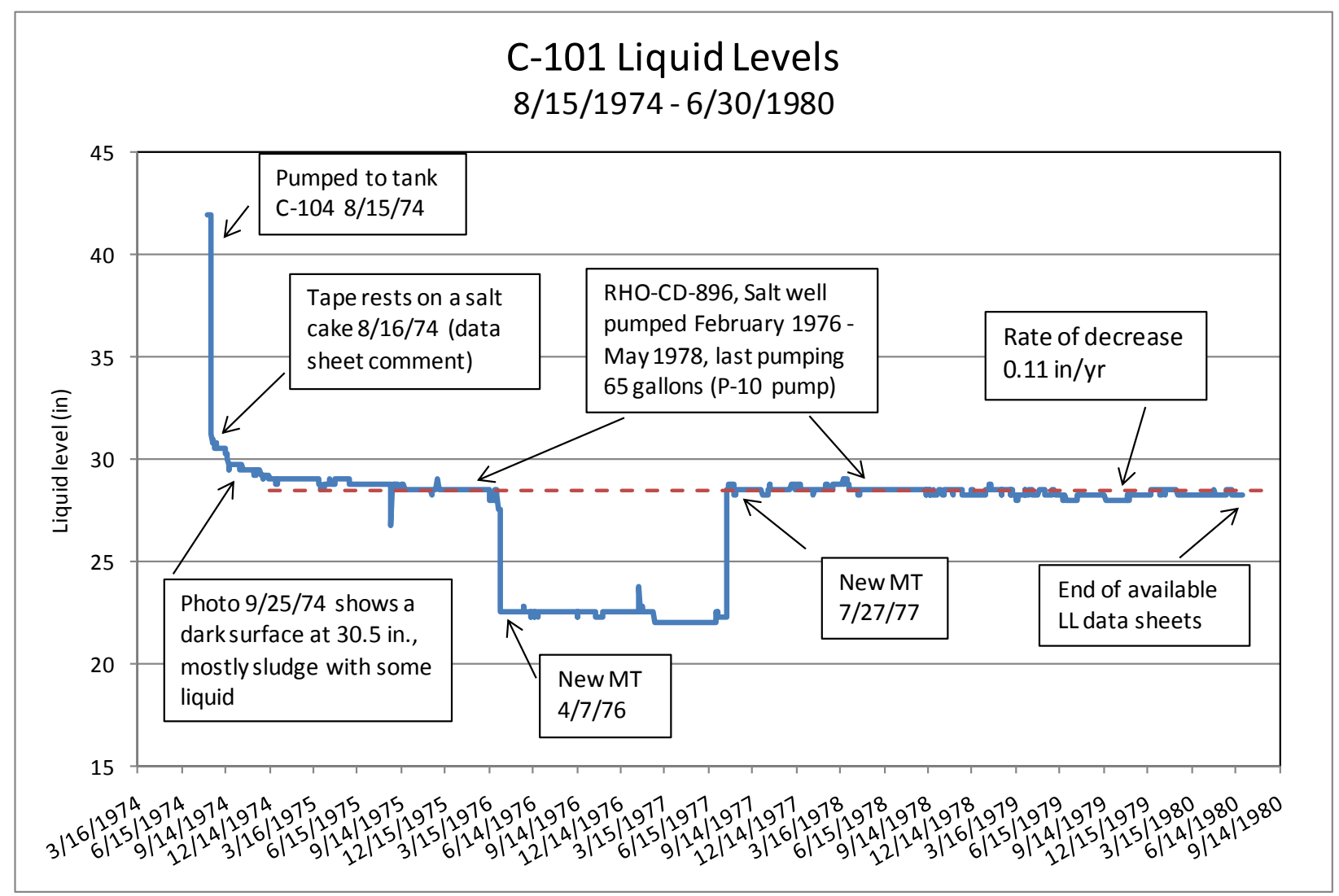

Note: MT levels referenced to the tank sidewall; add 12-inches to adjust to current waste levels.

The tank C-101 September 25, 1974 photos indicate a mostly sludge surface with some pools of liquid (745990-1 through 4CN). Figure 01-8 shows the waste surface at the location of the thermocouple and the manual tape at Nozzle R2, South PP-241-CR-01C. 
RPP-RPT-54914, Rev. 0

Figure 01-8. Tank C-101 Surface at the Thermocouple and Manual Tape Location Photograph September 25, 1974 (745590-24CN)

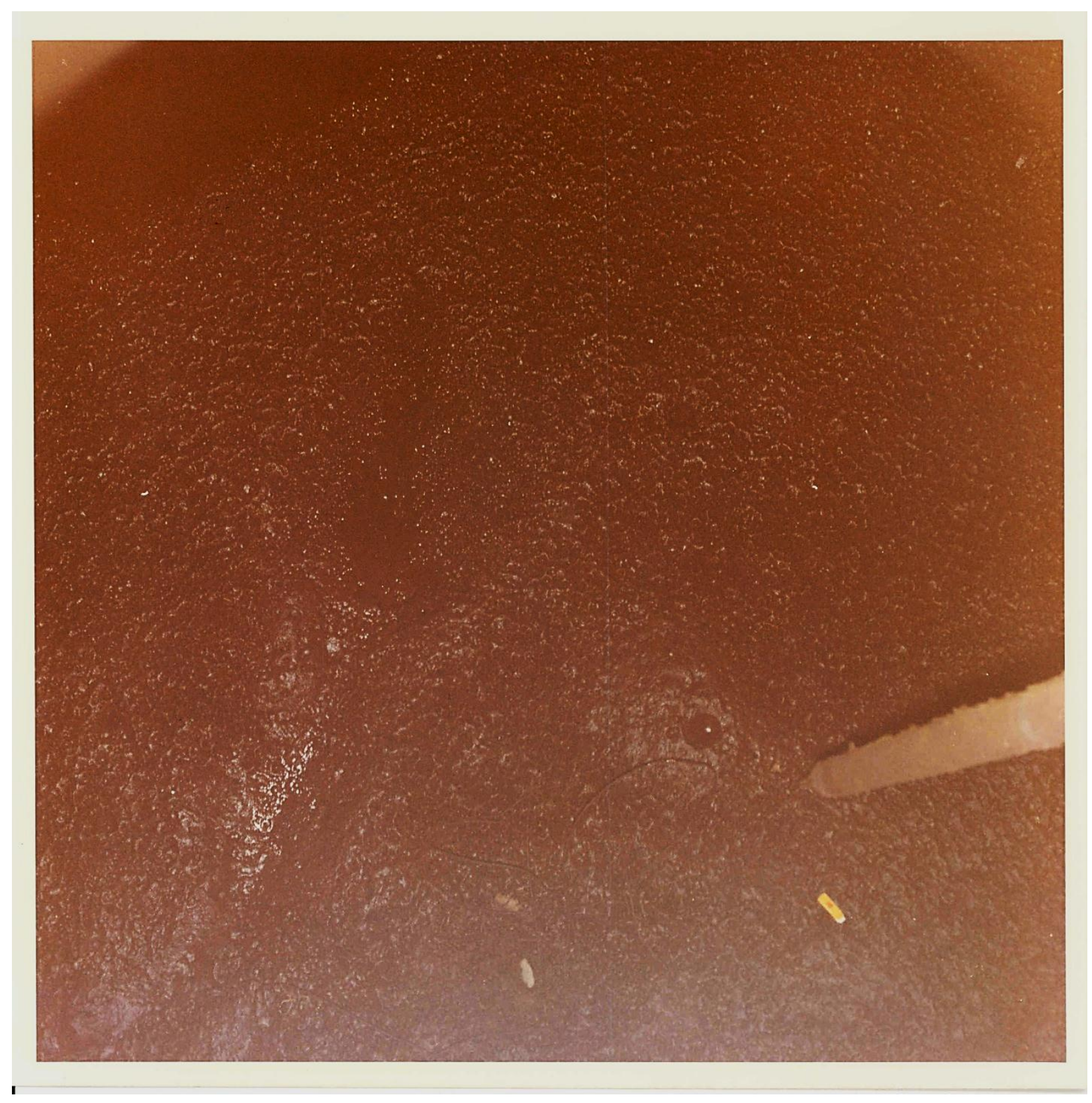




\section{B1.4 Period 4, January 5, 1981 to August 25, 2010}

The final period of the tank C-101 LL review in Figure 01-9 comes from the PCSACS program and covers the period from January 5, 1981 to August 25, 2010. The period begins with the MT plot on January 5, 1981 which ends on January 11, 2002 then continues with the ENRAF LL probe readings on April 24, 2002 to August 25, 2002. Photographs in Figure 01-10 and Figure 01-11 indicate that the atmospheric condensers as well as the exhaust fan stack (fan is not visible) were removed with the hatchway and piping blanked between May 14, 1982 and March 18, 1983. The plot indicates that the liquid level was continuing to be more stable between January 5, 1981 and the removal of the atmospheric condenser with a rate of decrease of $\sim 0.0015$-in/year. After the removal of the atmospheric condenser there is an apparent decreasing liquid level probably caused by atmospheric breathing and then instability as the MT comes into contact with solids.

Figure 01-9. Tank C-101 PCSACS LL January 5, 1981 - August 25, 2010

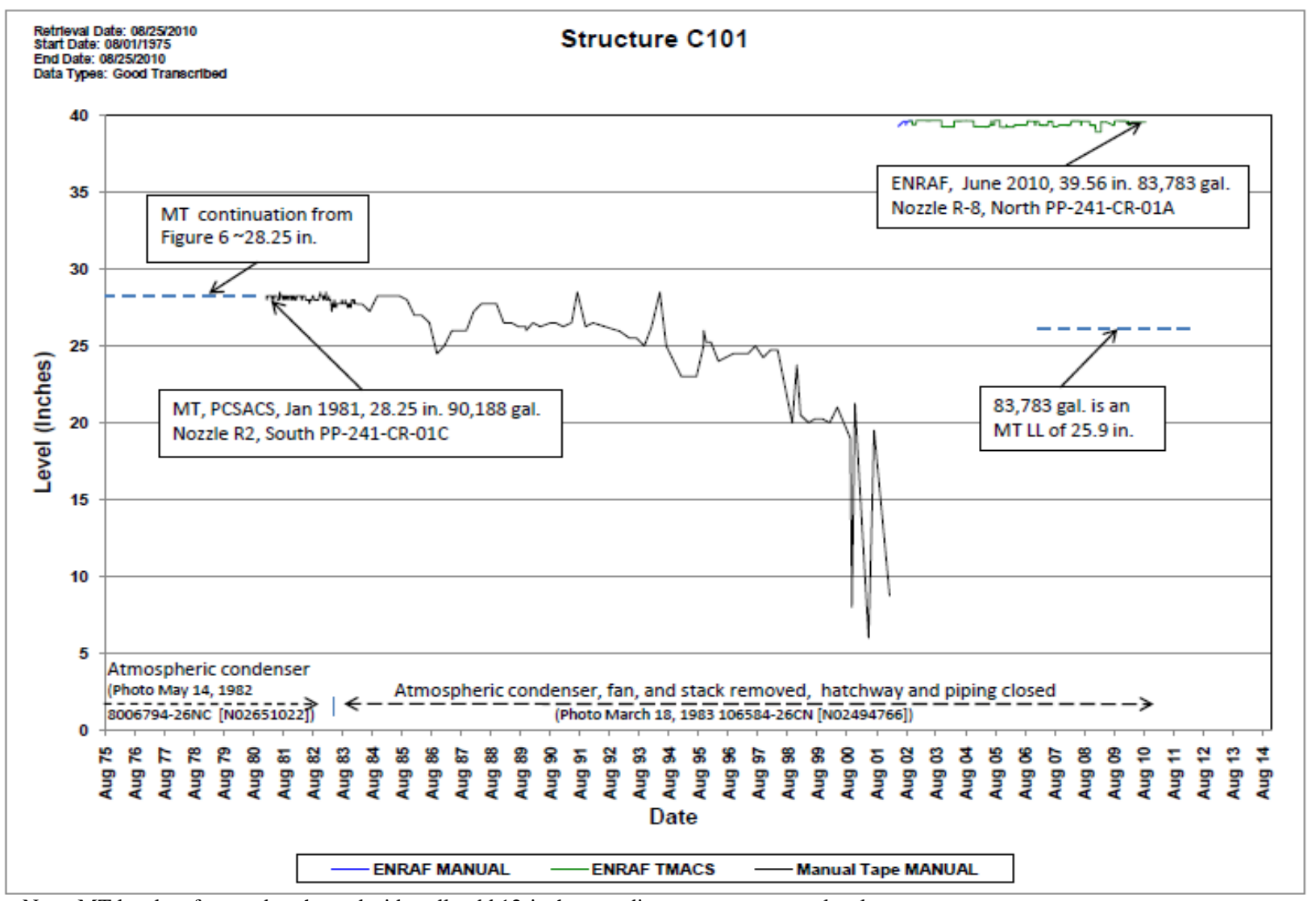

Note: MT levels referenced to the tank sidewall; add 12-inches to adjust to current waste levels.

The manual tape decrease from June 1982 to 1997 (when the manual tape contacted solids) is estimated to be roughly 6400 gallons or 530 gallons/year to 430 gallons/year respectively. A 1994 tank C-101 sample provided an estimated atmospheric breathing rate liquid removal of 430 gallons/year (HNF-3588, Rev. 1). 
Figure 01-10. Tanks C-101, C-102, and C-103 Condensers May 14, 1982 Photograph 8006794-6CN (N02651022)

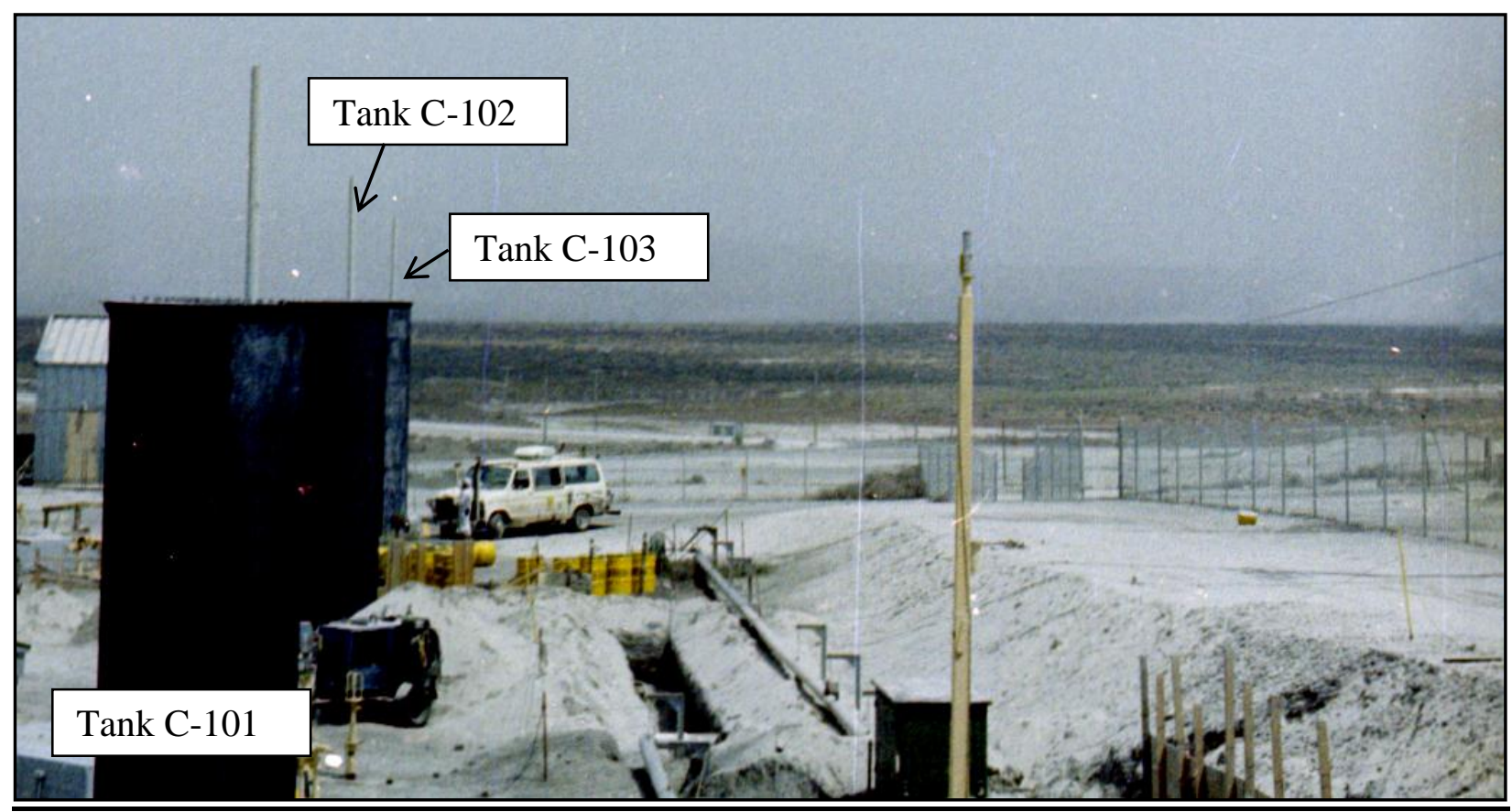

Figure 01-11. 241-C Farm Atmospheric Condensers, Fan and Stack Removed April 18, 1983

Photograph 106584-26CN (N02494766)

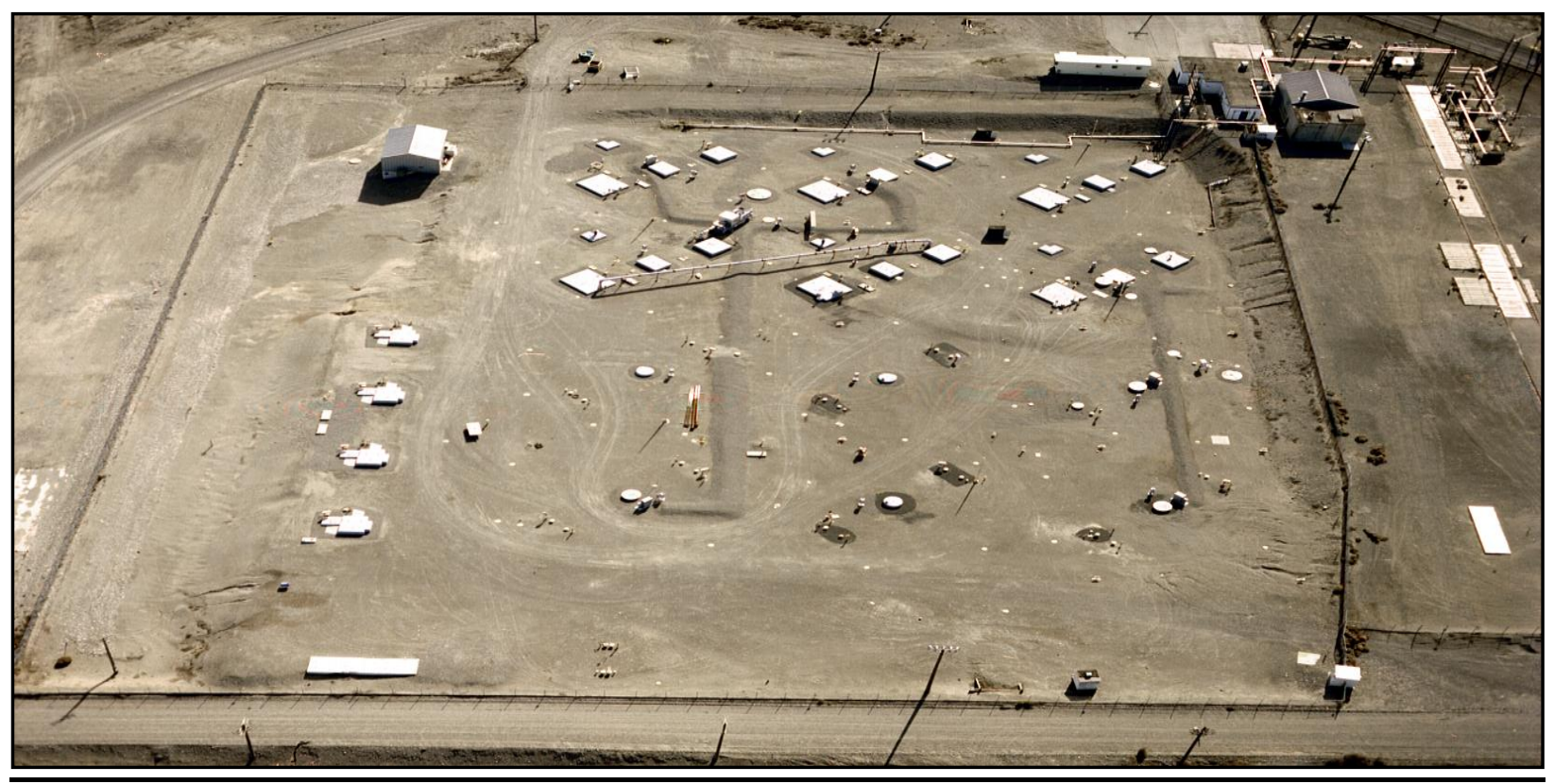


RPP-RPT-54914, Rev. 0

\section{B1.5 Overall In-Tank Data Conclusions}

The review of in-tank available liquid level data and photographs indicates the there is a strong possibility that if the tank did leak it was probably above the 40-in liquid level. 


\subsection{TANK 241-C-105 SEGMENT}

\section{TABLE OF CONTENTS}

5.1 Tank C-105 Background History …………...................................................... 5-4

5.2 Tank C-105 Operations Summary ……………................................................ 5-5

5.3 Tank Design/Construction ………………..................................................... 5-10

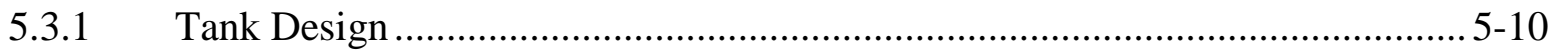

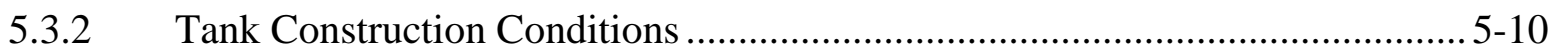

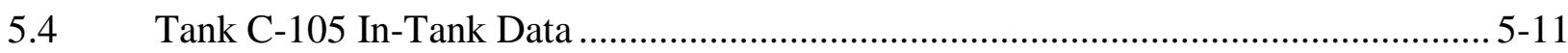

5.4.1 Liquid Level........................................................................................

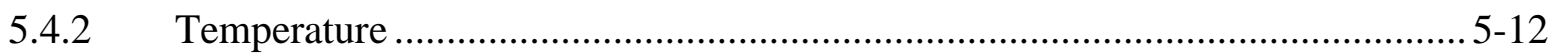

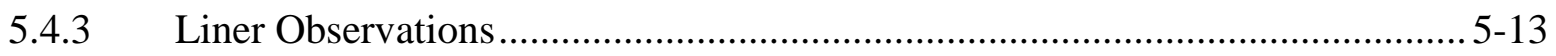

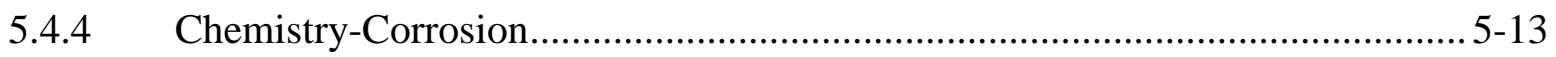

5.4.5 Photographs................................................................................ 5-15

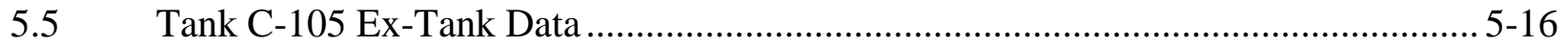

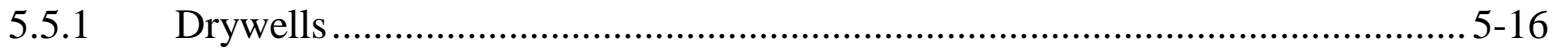

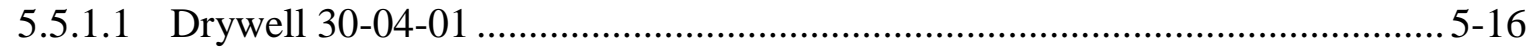

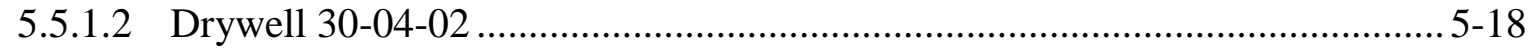

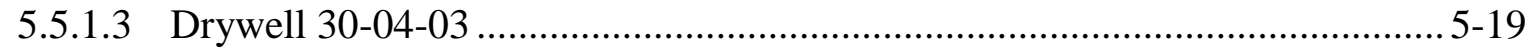

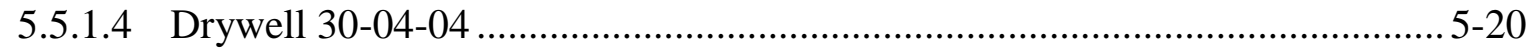

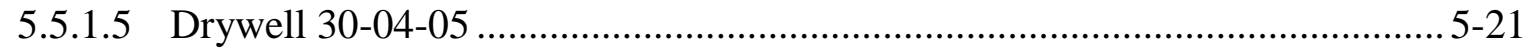

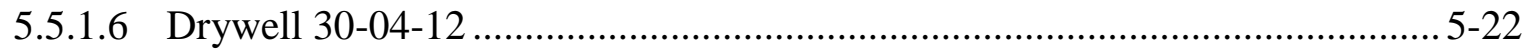

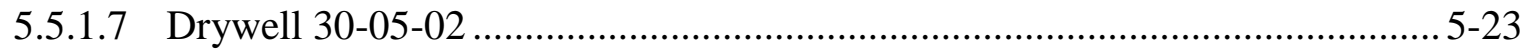

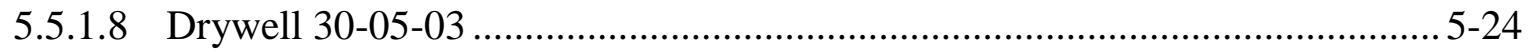

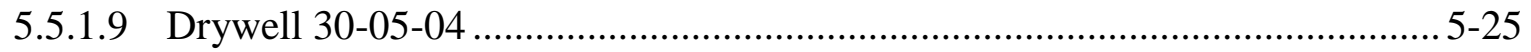

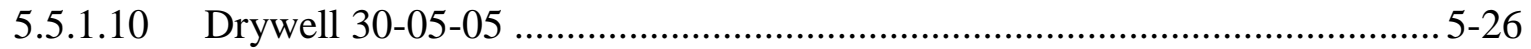

5.5.1.11 Drywell 30-05-06 ……………………................................... 5-27

5.5.1.12 Drywell 30-05-07 …………………….................................. 5-28

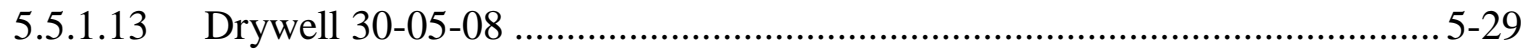

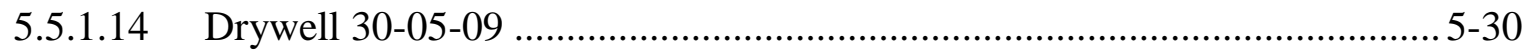

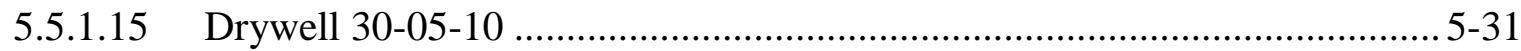

5.5.1.16 Drywell C4297 and Direct Push C7469 …………………....................... 5-32 


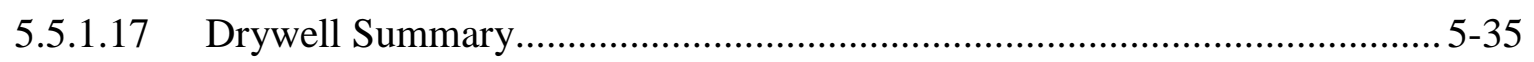

5.6 Possible Tank C-105 Liner Leak Location(s) …………………............................ 5-35

5.6.1 Leak Detected Before 1974- Leak Site A ........................................................... 5-36

5.6.2 Leak Detected Before 1974- Leak Site B ……………………………...... 5-37

5.6.3 Leak Location Summary ……………………………………………………. 5-38

5.7 Possible Tank C-105 Liner Leak Cause(s)........................................................ 5-40

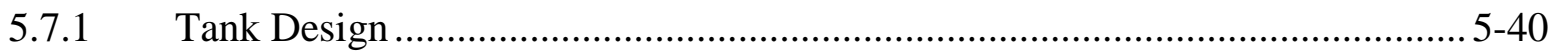

5.7.2 Thermal Conditions ...............................................................................

5.7.3 Chemistry-Corrosion ................................................................................. 5-40

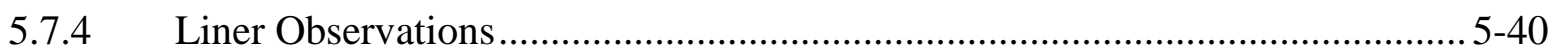

5.7.5 Tank Construction Temperature ............................................................... 5-41

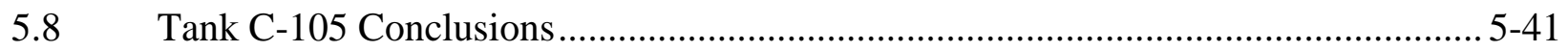

\section{Appendices}

Appendix A2 Tank C-105 Gross Gamma Drywell Data .....................................................A2-1

\section{LIST OF FIGURES}

Figure 5-1. Tank C-105 Associated Drywells ………………………………………............ 5-4

Figure 5-2. Operational Leak History of Tank C-105 ………………….............................. 5-9

Figure 5-3. B C T U Tank Farm Knuckle Configuration with Three-ply Waterproofing ........ 5-10

Figure 5-4. Tank C-105 End of Quarter Surface Level ........................................................... 5-12

Figure 5-5. Tank C-105 Inlet Nozzle Line V103 and Beachline ............................................... 5-15

Figure 5-6. Tank C-105 Cascade line and V103 Inlet Line .................................................... 5-16

Figure 5-7. Tank C-105 Drywell 30-04-01 (RPP-8321)......................................................... 5-17

Figure 5-8. Tank C-105 Drywell 30-04-02 (RPP-8321)........................................................ 5-18

Figure 5-9. Tank C-105 Drywell 30-04-03 (RPP-8321)........................................................ 5-19

Figure 5-10. Tank C-105 Drywell 30-04-04 (RPP-8321)....................................................... 5-20 
Figure 5-11. Tank C-105 Drywell 30-04-05 (RPP-8321) .................................................. 5-21

Figure 5-12. Tank C-105 Drywell 30-04-12 (RPP-8321) ..................................................... 5-22

Figure 5-13. Tank C-105 Drywell 30-05-02 (RPP-8321) .................................................... 5-23

Figure 5-14. Tank C-105 Drywell 30-05-03 (RPP-8321)……………………………….... 5-24

Figure 5-15. Tank C-105 Drywell 30-05-04 (RPP-8321) ...................................................... 5-25

Figure 5-16. Tank C-105 Drywell 30-05-05 (RPP-8321)..................................................... 5-26

Figure 5-17. Tank C-105 Drywell 30-05-06 (RPP-8321) .................................................... 5-27

Figure 5-18. Tank C-105 Drywell 30-05-07 (RPP-8321)...................................................... 5-28

Figure 5-19. Tank C-105 Drywell 30-05-08 (RPP-8321)...................................................... 5-29

Figure 5-20. Tank C-105 Drywell 30-05-09 (RPP-8321) ..................................................... 5-30

Figure 5-21. Tank C-105 Drywell 30-05-10 (RPP-8321) ..................................................... 5-31

Figure 5-22. Spectral Gamma Analyses of Drywell C4297 RPP-35484, Rev. 1 ……............. 5-32

Figure 5-23. Direct Push C7469 Small Diameter Gamma Survey RPP-RPT-43725 …............ 5-33

Figure 5-24. Direct Push C7469 and Drywell 30-05-07 Soil Contamination Profiles Comparison (RPP-ASMT-46452, Rev. 0) …………………………….........5-34

Figure 5-25. Tank C-105 Possible Leak Location (Before 1974) ………………………........ 5-36

Figure 5-26. Tank C-105 Possible Leak Location (Before 1974) ………………………........ 5-37

Figure 5-27. Tank C-105 Possible Radial Leak Locations ........................................................ 5-39

\section{LIST OF TABLES}

Table 5-1. Tank C-105 Waste Storage Chronology ............................................................. 5-14

Table 5-2. Waste Chemistries for Waste Types Stored in Tank C-105 ................................... 5-14

Table A2-1. Tank C-105 Drywell Radioactivity (K counts per minute) (March 1973 through March 1987) ..................................................................................... 22-2 


\subsection{TANK C-105 BACKGROUND HISTORY}

This section provides information on the historical waste loss event associated with Single-Shell Tank (SST) 241-C-105 (C-105). There are fifteen drywells located around tank C-105 with specified distances from the drywell to the tank footing shown in Figure 5-1: 30-05-02, 30-0510, installed in November 1972; 30-05-04, 30-04-02, 30-04-12 installed in December 1972; 3004-04, 30-05-05, 30-05-09, installed in June 1974; 30-04-01, 30-04-03, 30-04-05, 30-05-06, 3005-07 and 30-05-08, installed in July 1974; 30-05-03, installed in September 1974. Two subsequent drywells are also included: C4297, installed in April 2004; and direct push C7496, installed in October 2009. A detailed drywell review is included in Section 5.5.1.

Figure 5-1. Tank C-105 Associated Drywells

Tank inner ring is steel liner; outer ring is outer edge of tank footing

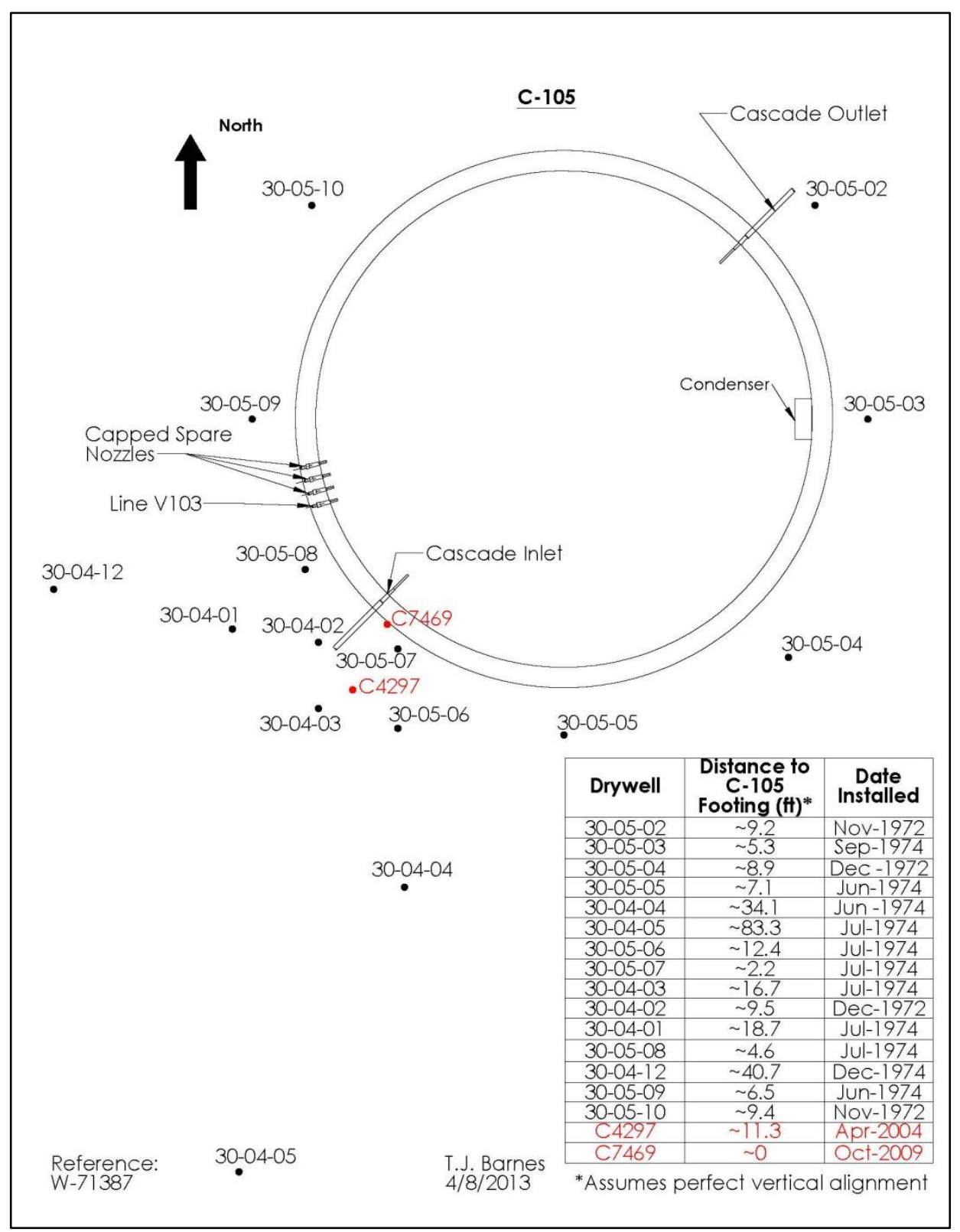


The bottom of the tank footing is 37-ft 5-in Below Grade Surface (BGS) with $~ 5.5$-ft soil cover over the dome (WHC-SD-WM-TI-665, Soil Load above Hanford Waste Storage Tanks; BPF-73550, Specifications for Construction of Composite Storage Tanks Blg. No. 241, Hanford Engineer Works, Project 9536). The cascade outlet pipe centerline at the tank liner is $\sim 20$-ft 7-in BGS which corresponds to a waste volume of $\sim 545 \mathrm{kgal}$ (193.5-in manual tape liquid level). The cascade inlet pipe centerline at the tank liner is $\sim 20-\mathrm{ft} 4$-in BGS which corresponds to a waste volume of $\sim 553 \mathrm{kgal}$ (196.5-in manual tape liquid level). The capped spare nozzles centerline at the tank liner is $\sim 20$-ft 3-in BGS which corresponds to a waste volume of $\sim 557 \mathrm{kgal}$ (198-in manual tape liquid level) (BPF-73550 Sheet D-5; BPF-73550 Sheet D-7, Miscellaneous Details for 75 Foot Tanks; LET-082172, H.N. Raymond to C.J. Francis, August 21, 1972, Maximum Operating Levels and Cascade Levels in 200-West Area Tank Farms).

\subsection{TANK C-105 OPERATIONS SUMMARY}

Tank C-105 is the second tank in a cascade of three tanks continuing from tanks C-104 to C-106. In January 1947, tank C-104 began to receive metal waste (MW) from the 221-B Plant (B Plant) Bismuth Phosphate Process. In February 1947, tank C-104 was full of MW and began to cascade to tank C-105. By June 1947, tank C-105 was filled and MW began to cascade into tank C-106. The three tank cascade was filled with MW in November 1947. The MW remained in tank C-105 until it was sluiced out in 1953 and 1954, and after the last transfer of MW slurry, virtually no solids remained in the tank (RPP-ENV-33418, Rev. 1 Hanford C-Farm Leak Assessments Report: 214-C-101, 214-C-110, 241-C-111, 241-C-105, and Unplanned Waste Releases).

During July and August of 1954, tank C-105 was filled with Tri-Butyl Phosphate (TBP) Plant waste (HW-32697, page 4 and HW-33002, page 4). Tank C-105 contained a total volume of 546 kgal after receiving this TBP waste, which corresponds to a waste height of 17-ft 4-in above the center of the tank bottom. The spare inlet nozzles on the SSTs are at a height of 17-ft 4-in (referenced from the center of the tank bottom) and it is known from the tank BX102 waste loss event investigation (HW-20742, page 5) that some of the spare nozzles on SSTs are poorly sealed. It is possible that some TBP waste was lost in August 1954 through the spare inlet nozzles to the soil nearby tank C-105. Tank C-105 remained filled at $546 \mathrm{kgal}$ from August 1954 through February 1956 (HW-41812, page 4).

In March 1956, approximately 294 kgal of TBP waste was transferred from tank C-105 to 244CR Vault for ferrocyanide scavenging of Cs-137 and Sr-90, leaving $252 \mathrm{kgal}$ of waste (HW42394, page 4). An additional $173 \mathrm{kgal}$ of the TBP waste was transferred in April 1956 from tank C-105 to 244-CR Vault for ferrocyanide scavenging, leaving a total of $79 \mathrm{kgal}$ (including 15 kgal of sludge) of waste in tank C-105 (HW-42993, page 4). No waste was added or removed from tank C-105 from May 1956 through July 1956.

In August 1956, the tank was utilized as a receiver for PUREX coating removal waste (CWP). Approximately $451 \mathrm{kgal}$ of CWP was pumped from tank C-104 into tank C-105, filling the tank to $530 \mathrm{kgal}$ (HW-45140, page 4). No waste was added or removed from tank C-105 through March 1957, but the total waste volume was adjusted to $535 \mathrm{kgal}$ (HW-48846, page 4) based on a new electrode measurement in February 1957 which resulted in a 6 kgal material balance discrepancy. 
Beginning in April 1957, tank C-105 received CWP that was then transferred to other SSTs within C Farm and 241-BY Farm. Tank C-105 was filled and emptied several times from April 1957 through April 1960 with CWP (HW-65272, page 4). The monthly waste status summary reports for April 1957 through April 1960 do not indicate the total waste volume in tank C-105 exceeded the height of the spare inlet nozzles. On April 30, 1960, the waste total volume reported in tank C-105 was $527 \mathrm{kgal}$ (HW-65272, page 4). From May 1960 (HW-65643, page 4) through December 1960 (HW-68292, page 4), the total waste volume in tank C-105 was reported as $529 \mathrm{kgal}$, based on a new waste level electrode reading taken in May 1960. The total waste volume in tank C-105 was reported as $521 \mathrm{kgal}$ on June 30, 1961 (HW-71610, page 4); an unexplained $8 \mathrm{kgal}$ decrease during the 6 months from the previously reported waste volume of $529 \mathrm{kgal}$ in December 1960. The tank C-105 waste volume was reported as $521 \mathrm{kgal}$ in December 1961 (HW-72625, page 4), $519 \mathrm{kgal}$ in June 1962 (HW-74647, page 4), and $519 \mathrm{kgal}$ in December 1962 (HW-76223, page 4).

In May 1963, $394 \mathrm{kgal}$ of waste was transferred from tank C-105 to tank C-102 in order to use tank C-105 as an emergency spare for waste from 241-A Farm (HW-77795, page B-1), leaving $125 \mathrm{kgal}$ (HW-78279, page 4). In the fourth quarter of 1963, $407 \mathrm{kgal}$ of neutralized PUREX supernatant waste (PUREX HLW) were transferred from tank A-102 to tank C-105 to support sluicing operation testing that was conducted in tanks A-102 and A-103 (HW-80379, page 4 and HW-78076, page B-1). The process records examined did not indicate the underground transfer lines that were used to transfer PUREX HLW from tank A-102 into tank C-105. Since none of the records indicate tank A-102 waste was transferred into tank C-104, it is assumed that the cascade line was not used for this transfer. Tank C-105 contained a total of $532 \mathrm{kgal}$ following this transfer.

A 36-in (101 kgal) liquid level decrease occurred in tank C-105 between May 1963, when it was filled with PUREX HLW in the fourth quarter of 1967 (ARH-95, page 5). Records state the loss was due to "steaming" or "evaporation", without further elaboration. Supporting temperature data for 1963 could not be located to verify evaporation (i.e. steaming) of waste from tank C-105 (ARH-CD-948).

The PUREX HLW transferred into tank C-105 during May 1963 originated from tank A-102. The temperature of PUREX HLW stored in tank A-102 was measured to range between $94^{\circ} \mathrm{C}$ to $170^{\circ} \mathrm{C}$ from January 1963 through May 11, 1963 prior to the transfer to tank C-105. The higher temperature readings in tank A-102 were experienced when the waste liquid level decreased from $~ 350$-in to $~ 300$-in. On May 15, 1963, the liquid level in tank A-102 was increased to 345in and the waste temperature was reported to be $105^{\circ} \mathrm{C}$ (IDMS \# D197260431, History - 241-A Tank Farm). Tank A-102 was equipped with air-lift circulators which aided in cooling the waste temperature. Clearly the waste stored in tank A-102 was capable of generating sufficient heat to cause liquid evaporation.

After transferring $407 \mathrm{kgal}$ of PUREX HLW from tank A-102 to tank C-105, evaporation of this waste would still be expected to occur in tank C-105. The waste volume in tank C-105 had reduced to $431 \mathrm{kgal}$ by September 30, 1967 (ARH-95, page 5). Beginning on December 27, 1967, PUREX HLW was transferred from tank C-105 to the 221-B Plant to separate Cs-137 by 
ion exchange (IX) processing (ARH-N-82, 1968, Fission Process Products Summary, page 140). The concentration of Cs-137 in tank C-105 supernatant was reported as $8.7 \mathrm{Ci} / \mathrm{gal}$ in December 1967 (ARH-N-82, page 140). The Cs-137 concentration in tank C-105 supernatant would have been $~ 9.7 \mathrm{Ci} / \mathrm{gal}$ (total of 5,160,000 curies) in May 1963, accounting for radionuclide decay and the volume of waste $(532 \mathrm{kgal}$ ) as of May 1963. Approximately 83,000 Btu/hr of radiolytic decay heat would be generated from the Cs-137 stored in tank C-105. Tank C-105 was equipped with an atmospheric condenser at the time PUREX HLW was stored which would have allowed discharge of some condensate to the atmosphere. Collectively, this information supports PUREX HLW stored in tank C-105 was capable of evaporating liquid. By 1971, the tank was placed on active ventilation. After mid-1971 the tank received frequent cooling water additions to cool the sludge. Prior to 1984 and from the mid-1985 to the mid-1990 the sludge temperature was controlled by frequent water additions (RPP-ASMT-39801, Rev. 1).

From 1968 through 1978, tank C-105 received additional PUREX HLW, PUREX sludge supernatant (PSS), REDOX neutralized supernatant (RSN) and 221-B Plant cesium ion exchange wastes for rework from 241-A, 241-AX, and 241-TX Farm, tanks C-103 and C-106, and doubleshell tank (DST) 241-AY-102. Some solids contained in the 241-A and 241-AX Farm tanks are believed to have been transferred to tank C-105 along with the PUREX HLW and PSS wastes. The PUREX HLW and PSS were pumped periodically to the 221-B Plant for cesium IX recovery processing. The total waste volume in tank C-105 was varied from a $198 \mathrm{kgal}$ (including $136 \mathrm{kgal}$ of sludge) to $542 \mathrm{kgal}$ (including $109 \mathrm{kgal}$ of sludge). The last transfer from tank C-105 occurred in June 1979. Between the last transfer and December 30, 1986, approximately $108 \mathrm{kgal}$ of water was added to the tank for evaporative cooling. Records indicate that periodic water additions continued until March 1991.

Tank C-105 was first suspected of leaking in March 1974 after drywell 30-04-02, located halfway between tanks C-104 and C-105, reported an increase in radiation at 40-ft BGS (OR 74120, Increasing Drywell Radiation Between Waste Tanks 104-C and 105-C). Ten additional drywells were drilled in the vicinity to investigate the contamination (see Section 5.5.1). During installation, highly contaminated soil had to be removed from near both ends of the tank C104/tank C-105 cascade line. One of these additional drywells (30-05-07) drilled reported significant radiation at the tank base questioning the integrity of tank C-105.

After 1978, supernatant was removed from tank C-105 and the tank was maintained at a minimum supernatant heel. Until the early 1990s, the sludge in this tank generated significant radiolytic decay heat to cause evaporation of water to occur. Water was periodically added to the tank to cool the sludge. Water addition was stopped in the mid-1990s after determining that the radiolytic decay heat generation had declined sufficiently. Tank C-105 was declared interim stabilized October 31, 1995 with $131 \mathrm{kgal}$ of sludge, $2 \mathrm{kgal}$ supernatant, and $29.5 \mathrm{kgal}$ drainable interstitial liquid. In 1993, WHC-SD-EN-TI-185, Assessment of Unsaturated Zone Radionuclide Contamination Around Single-Shell Tanks 241-C-105 and 241-C-106, concluded there was no "direct evidence or positive proof of an active tank leak from either C-105 or C-106."

In February 2008, RPP-ENV-33418 concluded that the soil contamination detected in drywell 30-05-07 was probably the result of a tank leak and recommended a TFC-ENG-CHEM-D-42. Results from this initial assessment, completed in December 2008, recommended that the 
existing "sound" classification be maintained pending collection of additional field data from installation of direct pushes (RPP-ASMT-39801, Rev. 0). After one additional direct push was installed and further analyses, the leak integrity status of tank C-105 was changed to "assumed leaker" in April 2010 (RPP-ASMT-39801, Rev. 1; RPP-ASMT-46452, Rev. 0).

The operational history of tank C-105 leak related details including the liquid level is charted in Figure 5-2. 


\section{Figure 5-2. Operational Leak History of Tank C-105}

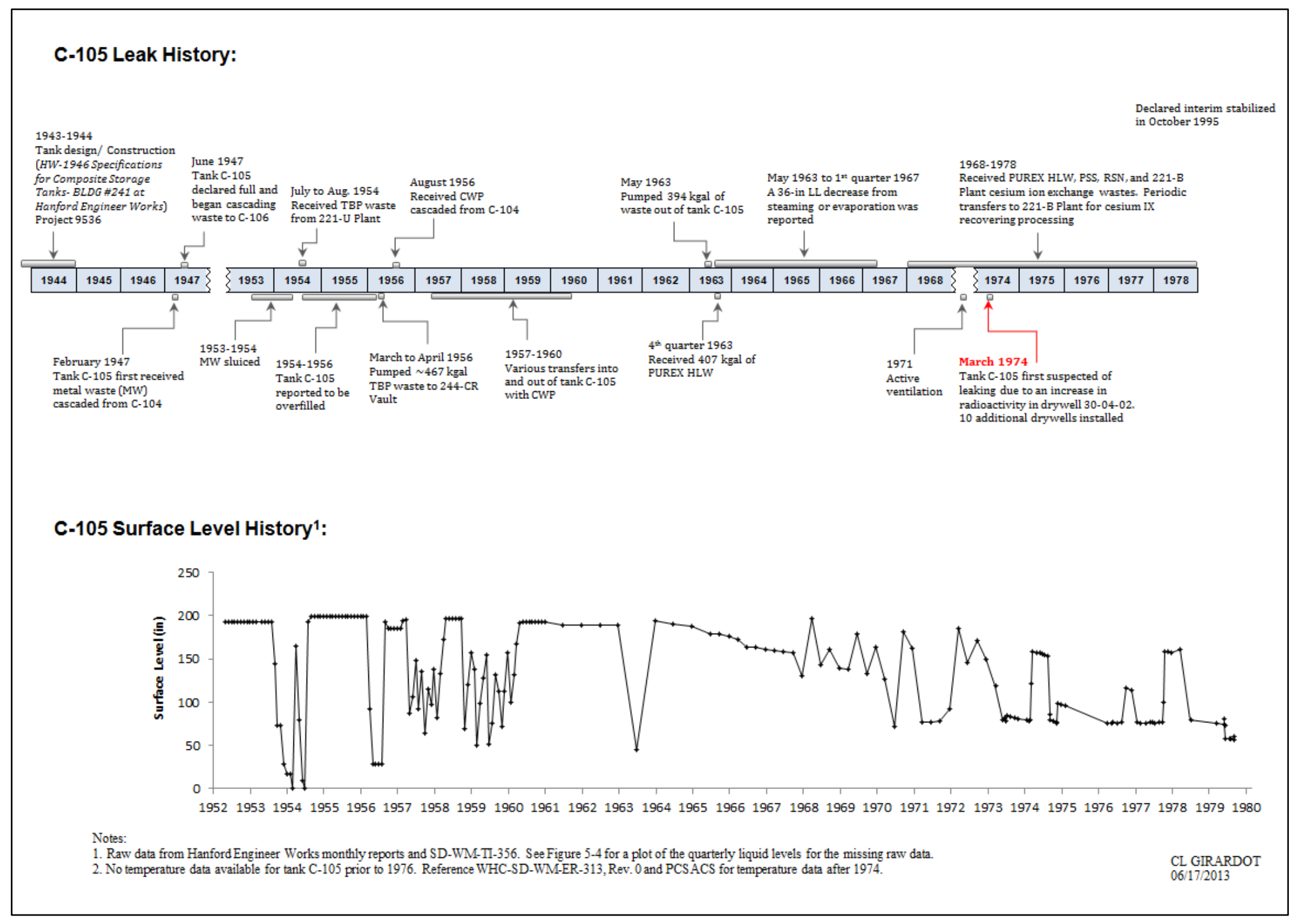




\subsection{TANK DESIGN/CONSTRUCTION}

\subsubsection{Tank Design}

The steel bottoms of the $\mathrm{C}$ Farm tanks intersect the sidewall on a 4-ft radius knuckle transition (BPF-73550, Drawings D-2 and D-3). Figure 5-3 shows the detail of the rounded knuckle transition, the three-ply asphaltic membrane waterproofing between the liner and the concrete, a notched footing construction joint, and the concrete shell. These features are common to all $\mathrm{C}$ Farm tanks (see Section 3.1.1).

\section{Figure 5-3. B C T U Tank Farm Knuckle Configuration with Three-ply Waterproofing BPF-73550, Sheet B5}

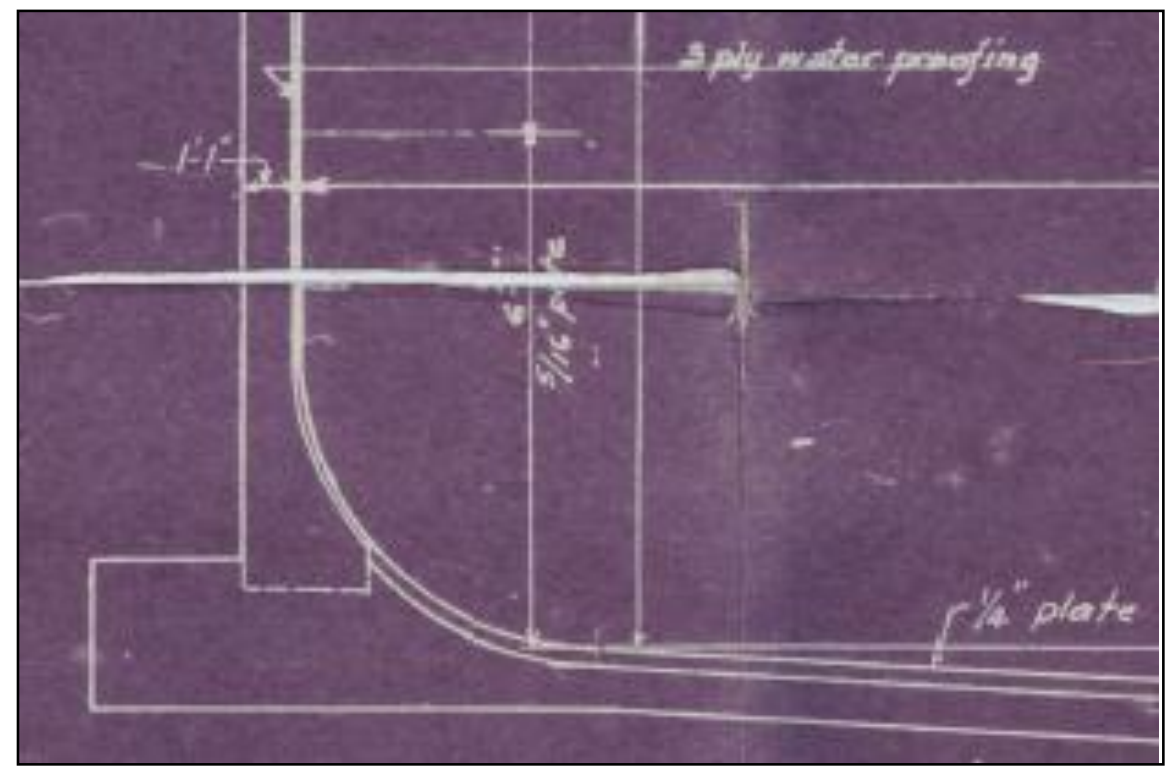

\subsubsection{Tank Construction Conditions}

The C Farm tanks were constructed between August 1944 and December 1944. Temperatures are not available for 1944 between the dates of May 18 and December 1. As a note, it was found that the weather station was shut down during this period of time. There is a possibility that the 400-ft tower was under construction during that time which is right next to the weather station building. The building may have been closed during that time for safety reasons (Meteorological and Climatological Services [MCS]).

As described in Section 3.1.2, cold weather affects the ductile-to-brittle steel transition temperature, with $18^{\circ} \mathrm{F}$ being the assumed unrestricted low temperature construction limitation for the carbon steel liner, which could result in a fracture upon impact. However, the time of year during construction of the C Farm tanks would indicate that there would probably not be temperatures low enough to affect the ductile-to-brittle transition temperature.

Design, fabrication, and erection of the tank steel lining were required to be in accordance with current "Standards Specifications for Elevated Steel Water Tanks, Standpipes and Reservoirs" as promulgated by the "American Water Works Association" (BPF 73550). Welding requirements 
RPP-RPT-54914, Rev. 0

were required to conform to the American Welding Society's "Code for Arc and Gas Welding in Building Construction", Section 4.

\subsection{TANK C-105 IN-TANK DATA}

\subsubsection{Liquid Level}

Tank C-105 first received waste in February 1947 and was reported to be overfilled from August 1954 through February 1956 (see Figure 5-4). No unexplained liquid level decreases were reported until May 1963 to the $4^{\text {th }}$ quarter 1967 when a 36-in liquid level decrease was reported in tank C-105, equivalent to a loss of approximately $101 \mathrm{kgal}$ (RPP-ASMT-39801, Rev. 1). Records state the loss was due to "steaming" or "evaporation" (see Section 5.4.2). Tank C-105 was kept in service with no future unexplained liquid level decreases and drywells were not installed until 1972-1974.

Tank C-105 was first suspected of leaking in August 1974 when radioactivity was detected in drywell 30-04-02 (see Section 5.5.1). During this time, liquid level decreases were reported to be normal due to evaporation consistent with the measured amount of water vapor in the exhaust system (OR 74-120). After radioactivity was reported in drywell 30-04-02, the liquid level was pumped down to approximately 78-in, and the operating level was restricted until additional drywells were installed. After further analyses, the tank was reported to not be actively leaking and returned to service in October 1974. No further liquid level decreases were reported until 1976.

In November 1976, a decrease in the tank C-105 liquid level that exceeded the action criteria was reported (OR 76-153, ARHCO Occurrence Report: Liquid Level Decrease Meeting Criteria). During this period, the tank was being exhausted via the tank C-105-to-C-106 cascade line and a dedicated exhauster connected to tank C-106. Prior to the installation of the exhauster the tank was steaming, see the evaporation discussion in Section 5.2. The liquid level loss was attributed to evaporation from the 350 to 400 cubic feet per minute airflow through the tank with the temperatures above $180^{\circ} \mathrm{F}$ up to possibly boiling. Tank C-105 continued to be kept in service with the last transfer out of the tank in June 1979. Water additions for cooling (see Section 5.4.2) probably below at least $180^{\circ} \mathrm{F}$ continued until the mid-1990s with temperatures ranging from $\sim 145^{\circ} \mathrm{F}$ to $\sim 75^{\circ} \mathrm{F}$ between 1974 and mid 1990 (SD-WM-ER-313, section 6 of 14). No additional liquid level decreases were reported.

The liquid level plot in Figure 5-4 indicates the transfer activity into and out of tank C-105. The liquid levels are end of quarter levels so this figure may not reflect all transfers into and out of the tank that occurred during the operational history. See Figure 5-2 for historical monthly liquid level readings. 
Figure 5-4. Tank C-105 End of Quarter Surface Level

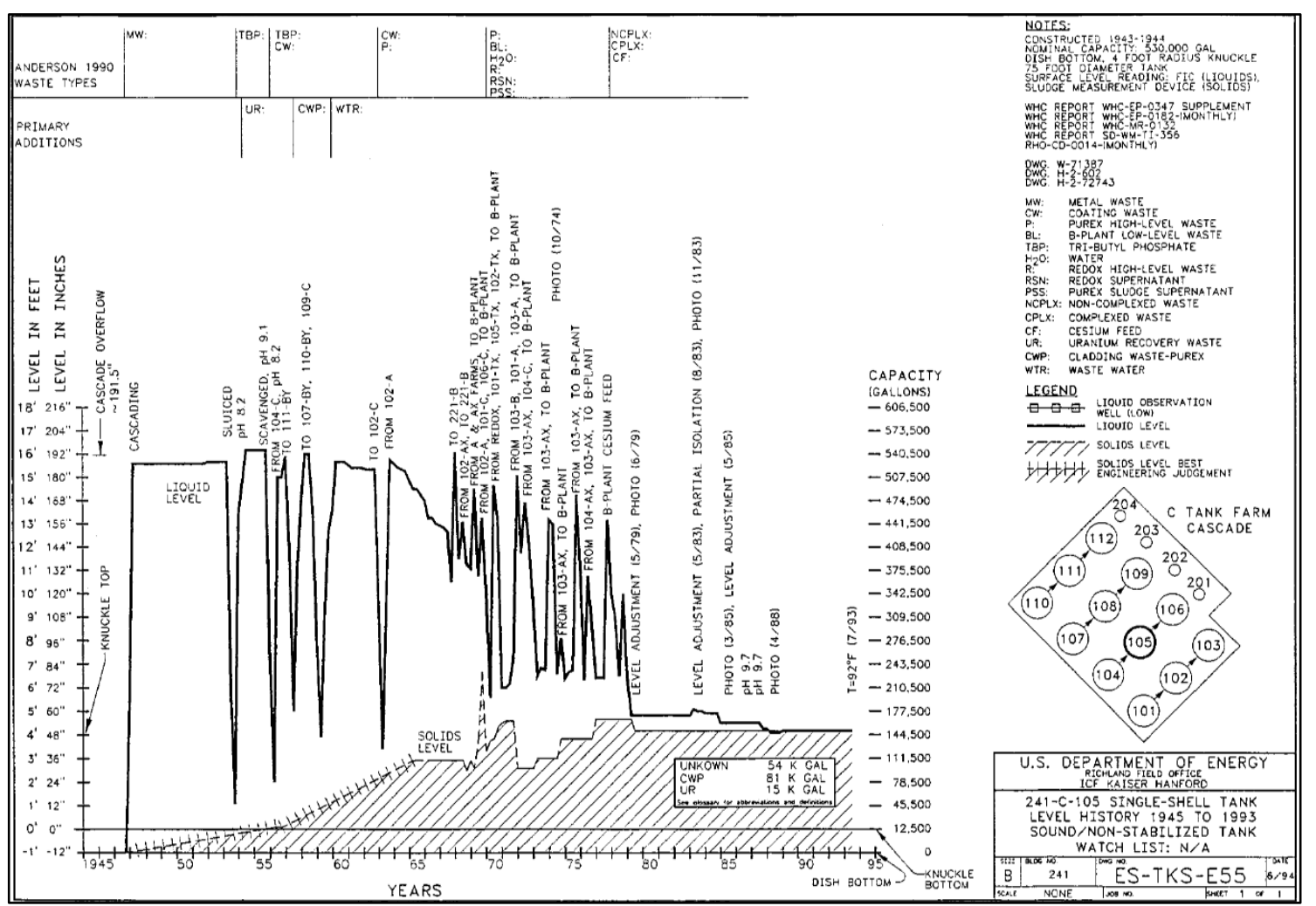

WHC-SD-WM-ER-349, Rev. 0, August 3, 1994, Historical Tank Content Estimate for the Northeast Quadrant of the Hanford 200 East Area

\subsubsection{Temperature}

No temperature data were recovered for tank C-105 from March 1946 when the tank was first put into service until 1974. The temperature of MW in tank C-105 through sluicing (1946 1953) prior to storage of TBP waste was probably similar to or less than tank C-101which also received MW. Four temperature data points were recovered from June 1946 to November 1947 for tank C-101 (see Section 4.4.2) ranging from $\sim 126^{\circ} \mathrm{F}$ to $\sim 169^{\circ} \mathrm{F}$. Tank C-105 was the second tank in the cascade where some cooling would have occurred versus tank $\mathrm{C}$-101 which was the first tank in the tank C-101 to tank C-103 cascade.

Tank C-105 received TBP waste from 221-U Plant from May 1953 to September 1956. TBP wastes were concentrated and cooled to $\sim 180^{\circ} \mathrm{F}$ within the plant and were estimated to be 110 $180^{\circ} \mathrm{F}$ after routing to the storage tanks. Tank C-105 was the second tank in the cascade which would have tended toward the lower end of the temperature range.

Tank C-105 received CWP from April 1960 to May 1963. The low fission product content of CWP and heat load would have resulted in a probable temperature of less than $100^{\circ} \mathrm{F}$.

In May 1963 PUREX HLW was transferred from A-102 and other 241-A Farm complex tanks to tank C-105 including some coating waste. No other waste transfers occurred until the $4^{\text {th }}$ quarter 1967. A 36-in (101 kgal) liquid level decrease occurred in tank C-105 between May 1963 and the $4^{\text {th }}$ quarter 1967. Records state the loss was due to "steaming" or "evaporation," without 
further elaboration. Supporting temperature data could not be located to verify evaporation from tank C-105 (ARH-CD-948).

The PUREX HLW transferred into tank C-105 during May 1963 originated from tank A-102. The temperature of PUREX HLW stored in tank A-102 was measured to range between $200^{\circ} \mathrm{F}$ to $338^{\circ} \mathrm{F}$ from January 1963 through May 11, 1963 prior to the transfer to tank C-105. The higher temperature readings in tank A-102 were experienced when the waste liquid level decreased from 350-in to 300-in. On May 15, 1963, the liquid level in tank A-102 was increased to 345in and the waste temperature was reported to be $221^{\circ} \mathrm{F}$ (IDMS \# D197260431). Tank A-102 was equipped with air-lift circulators which aided in cooling the waste temperature. Clearly the waste stored in tank A-102 was capable of generating sufficient heat to cause liquid evaporation.

Tank C-105 was equipped with an atmospheric condenser which was reported to be adequate for the waste temperatures and vapor loads for the original operations at approximately $180^{\circ} \mathrm{F}$ for supernatant and sludge (WHC-MR-0132, A History of the 200 Area Tank Farms). Even with some dilution the tank A-102 transfer probably resulted in temperatures exceeding $180^{\circ} \mathrm{F}$ up to possible boiling temperatures in tank C-105 which may have caused "steaming" to be visible from the atmospheric condenser. This along with the tank C-105 Cs-137 supernatant concentration of $\sim 9.7 \mathrm{Ci} /$ gal in May 1963 (RPP-ENV-33418) would confirm a relatively high temperature in tank C-105.

From 1968 through 1970 tank C-105 received PSS from 241-A and 241-AX Farms, transferred PSS to B Plant, and received waste from B Plant (RIX FP, BL). The temperature of the tank waste was high enough to install active ventilation in 1971. Supernatant continued to be transferred through tank C-105 to B Plant through June 1979 with frequent water additions for sludge temperature control. Sludge temperatures ranged from about $125^{\circ} \mathrm{F}$ in 1974 down to $<100^{\circ} \mathrm{F}$ by 1993 (WHC-SD-WM-ER-313). Water additions were discontinued mid-1990 after determining radiolytic decay heat generation had declined sufficiently.

\subsubsection{Liner Observations}

No liner observations relating to a tank C-105 leak have been found.

\subsubsection{Chemistry-Corrosion}

Tank C-105 began receiving MW cascaded from tank C-104 in February 1947 and received various waste types throughout operation as shown in Table 5-1. The typical concentrations for nitrite, nitrate, and hydroxide for these waste types are shown in Table 5-2. Nitrite and hydroxide are known as nitrate induced SCC inhibitors. One key characteristic for inhibiting $\mathrm{SCC}$ is to maintain a high ratio of SCC inhibitors to nitrate concentrations (see Section 3.2.4). 
RPP-RPT-54914, Rev. 0

Table 5-1. Tank C-105 Waste Storage Chronology

\begin{tabular}{|c|c|c|}
\hline Date & Waste Type & Length of Storage \\
\hline Feb. 1947 to June 1953 & MW & $\sim 6$ years \\
\hline July 1954 to July 1956 & TBP & $\sim 2$ years \\
\hline Aug. 1956 to May 1963 & CWP & $\sim 3$ years \\
\hline Oct. 1963 to Dec. 1967 & PUREX HLW & $\sim 6$ years \\
\hline 1968 to $1978^{1}$ & PUREX HLW, PSS, RSN, IX & $\sim 10$ years \\
\hline 1971 to 1986 & Periodic water additions & - \\
\hline
\end{tabular}

Table 5-2. Waste Chemistries for Waste Types Stored in Tank C-105

\begin{tabular}{|c|c|c|c|c|c|}
\hline Waste Type & {$\left[\mathrm{NO}_{3}{ }^{-}\right]^{1}$} & {$\left[\mathrm{NO}_{2}{ }^{-}\right]^{\mathbf{1}}$} & {$\left[\mathrm{OH}^{-}\right]^{\mathbf{1}}$} & \multicolumn{2}{|c|}{$\left[\mathrm{NO}_{\mathbf{3}}{ }^{-}\right] /\left(\left[\mathrm{OH}^{-}\right]+\left[\mathrm{NO}_{2}{ }^{-}\right]\right)$} \\
\hline MW & 0.59 & Not reported & 1.16 & $<0.5^{1}$ & $<2.5^{2}$ \\
\hline CWP & 0.6 & 0.9 & 1 & 0.3 & $<2.5^{2}$ \\
\hline TBP & 7.35 & Not reported & 0.09 & $>2.5^{3}$ & $<2.5^{2}$ \\
\hline IX & 0.49 & 1.9 & Not reported & $<0.26$ & $<2.5^{2}$ \\
\hline PSS & 4.2 & 0.22 & Not reported & $>2.5^{4}$ & $<2.5^{2}$ \\
\hline RSN & 3.08 & 0.18 & 1.26 & 2.1 & $<2.5^{2}$ \\
\hline PUREX HLW & 1.3 & Not reported & Not reported & NA & $<2.5^{2}$ \\
\hline
\end{tabular}

1. Reference WHC-EP-0449, 1991, The Sort on Radioactive Waste Type Model: A Method to Sort Single-Shell Tanks into Characteristic Groups.

2. OSD-T-151-00007 (2012) specification for waste chemistry

3. To be within the current DST specification limit, $\left[\mathrm{NO}_{2}^{-}\right]>2.8 \mathrm{M}$ which is unlikely

4. To be within the current DST specification limit, $\left[\mathrm{OH}^{-}\right]>1.5 \mathrm{M}$ which is impossible

The first waste type stored in tank C-105 was B Plant MW cascaded from tank C-104 and was stored in the tank for approximately six years. Metal waste alone should not be a concern for either pitting or SCC under the tank C-105 conditions.

Tank C-105 stored CWP for approximately three years. Tank C-105 also stored CWP and PUREX HLW for approximately six years. Coating waste and PUREX HLW should not be a concern for either pitting or SCC under the tank C-105 conditions.

Tank C-105 stored TBP waste from 221-U Plant from July 1954 to July 1956 after the tank was sluiced. Samples of TBP waste indicate hydroxide concentrations below $0.1 \mathrm{M}$ and nitrate concentrations above $6 \mathrm{M}$. These conditions of the TBP waste would likely create an environment conducive to SCC.

From 1968 to 1978, tank C-105 served as a feed tank which sent waste to B Plant for cesium fission product separation by ion exchange processing and received waste types PUREX HLW, PSS, RSN, and IX. Waste types PSS and RSN could create an environment conducive to SCC; however, frequent transfers into and out of the tank were occurring during this time and these waste types would likely be diluted with PUREX HLW and IX. Waste types PUREX HLW and IX should not be a concern for either pitting or SCC under the tank C-105 conditions. Therefore, 
it appears the waste types stored during this time frame should not be a concern for either pitting or SCC.

\subsubsection{Photographs}

Photographs taken in October 1974 show evidence of a waste "beachline" above the spare inlet 4-in sleeve penetrations in the tank sidewall (see Figure 5-5). This indicated that sometime during the 1954 - 1956 period, the waste stored in the tank exceeded $551 \mathrm{kgal}$, submerging both the cascade line inlet and the spare inlet nozzles (see Figure 5-6).

\section{Figure 5-5. Tank C-105 Inlet Nozzle Line V103 and Beachline}

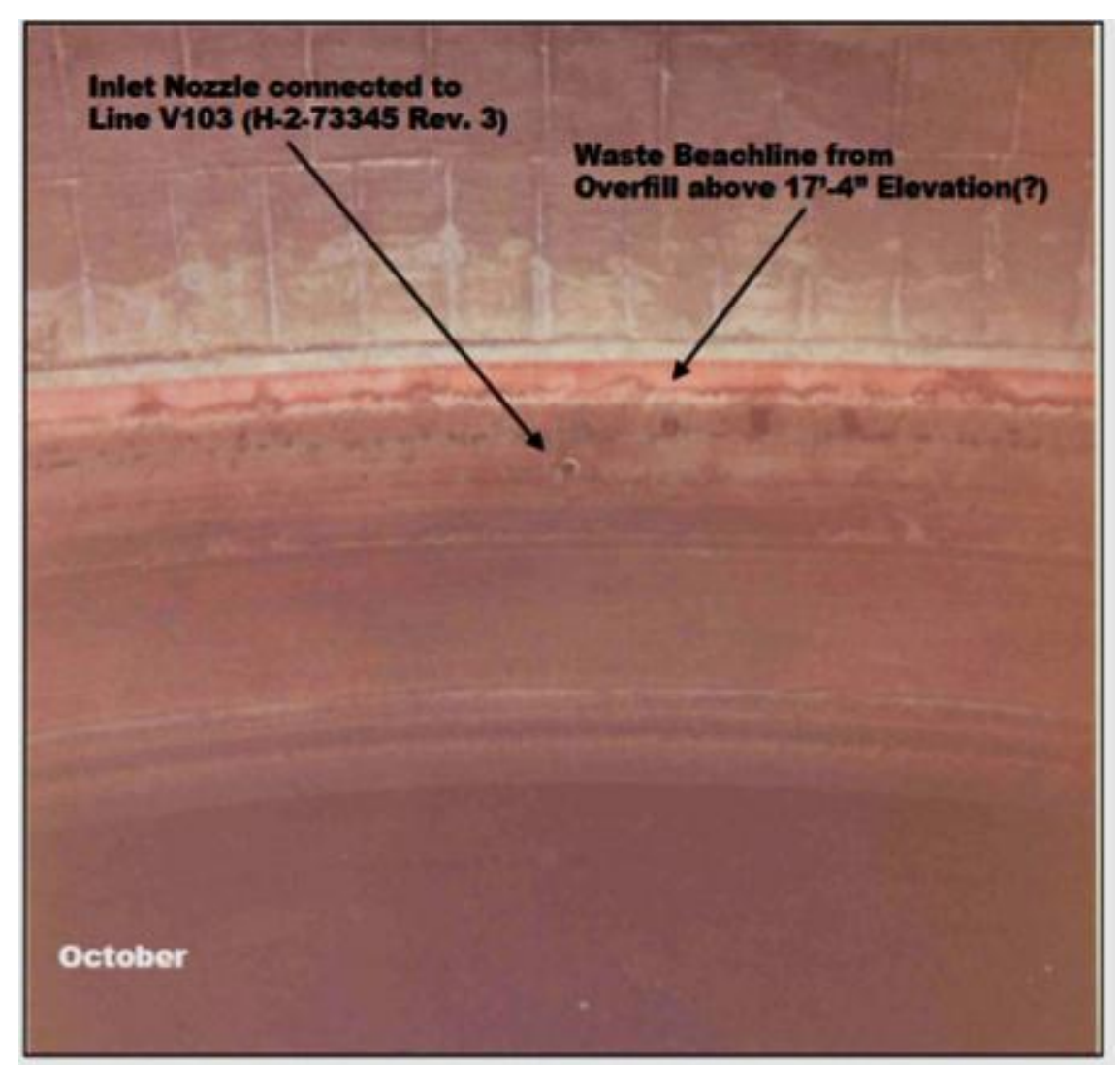

October 11, 1974 Waste Level = 78.8" (Negative 746325-29CN) 
Figure 5-6. Tank C-105 Cascade line and V103 Inlet Line

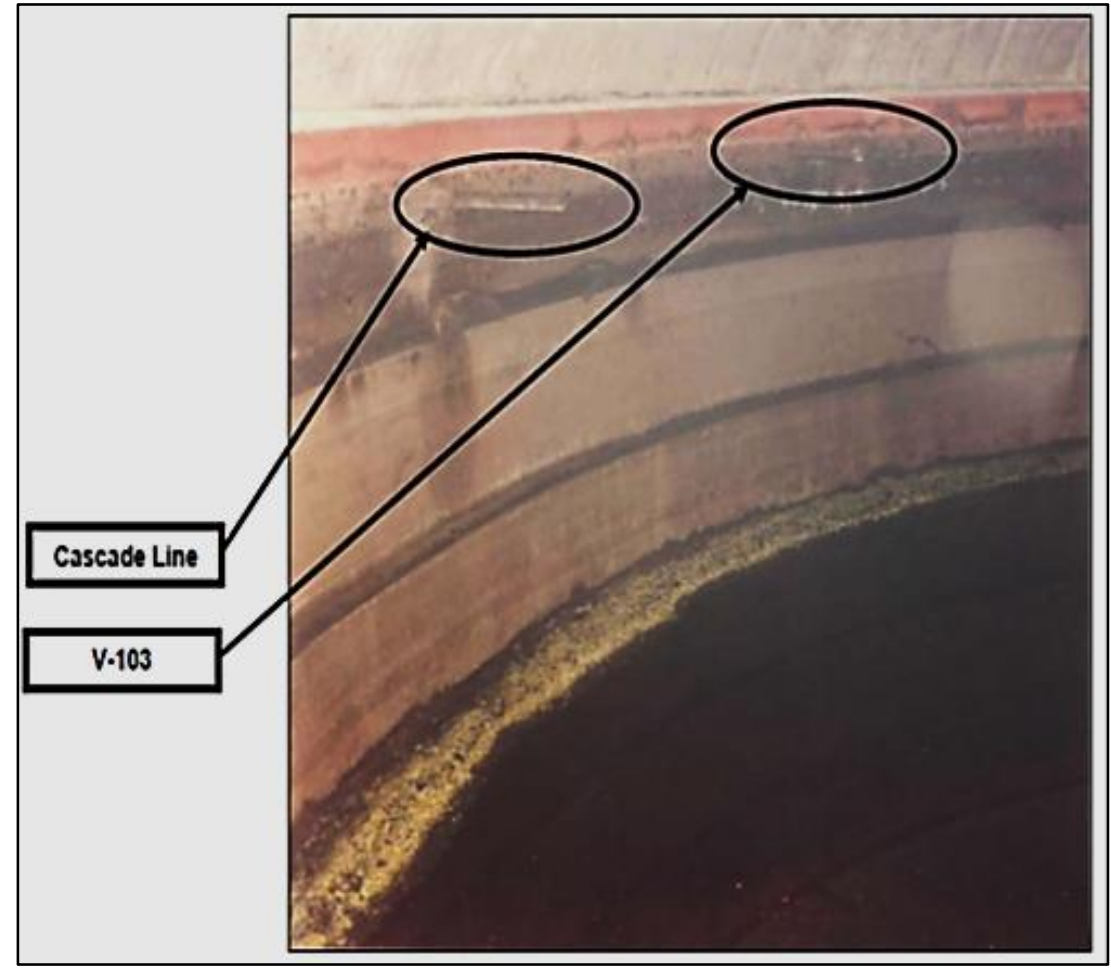

March 28, 1985 Waste Level = 55 inches (Negative 8502079-6CN

\subsection{TANK C-105 EX-TANK DATA}

\subsubsection{Drywells}

There are fifteen drywells located around tank C-101: 30-04-02, 30-04-12, 30-05-02, 30-05-04, and 30-05-10, installed in 1972; and 30-04-01, 30-04-03, 30-04-04, 30-04-05, 30-05-03, 30-05$05,30-05-06,30-05-07,30-05-08$, and 30-05-09, installed in 1974. All of the radiation readings in drywells are assumed to be maximum or peak readings unless otherwise noted (see Section 3.3.2). A drywell and direct push were installed in February 2004 and October 2009 near the southern portion of the tank. The following subsections report the available drywell information and the drywell summary section provides the analyses of the associated drywells with tank C105 .

\subsubsection{Drywell 30-04-01}

Drywell 30-04-01 was drilled in July 1974 with the first recoverable reading on August 16, 1974 reported as less than values (see 02). Readings continued to be reported as less than values through February 1987.

In September 1997, Cs-137 was detected continuously from the ground surface to the bottom of the logged interval, 49-ft BGS (GJ-HAN-87). From the ground surface to 5-ft BGS, concentrations ranged from 25 to $100 \mathrm{pCi} / \mathrm{g}$. Between 5 to $16.5-\mathrm{ft} \mathrm{BGS}$, concentrations were 10$20 \mathrm{pCi} / \mathrm{g}$, and between 25 to $45-\mathrm{ft}$ BGS concentrations ranged from 0.5 to $3 \mathrm{pCi} / \mathrm{g}$. Document 
GJ-HAN-87 reports, "Elevated levels of Cs-137 contamination were detected at approximately the same depths in other nearby boreholes and may be related to a leak from the C-104-to-C-105 cascade line described in Welty (1988). The distribution of this contamination may represent the accumulation of Cs-137 contamination on top of finer-grained sediments within the backfill material and at the base of the tank farm excavation."

Historical radioactivity in this drywell is very low and RPP-ASMT-39801 reports that radioactivity reported in this drywell does not support a tank C-105 liner leak. Therefore, drywell 30-04-01 is not being included as part of the leak location for tank C-105. Figure 5-7 shows the depths of radioactivity from 1975 to 1995 (RPP-8321).

Figure 5-7. Tank C-105 Drywell 30-04-01 (RPP-8321)

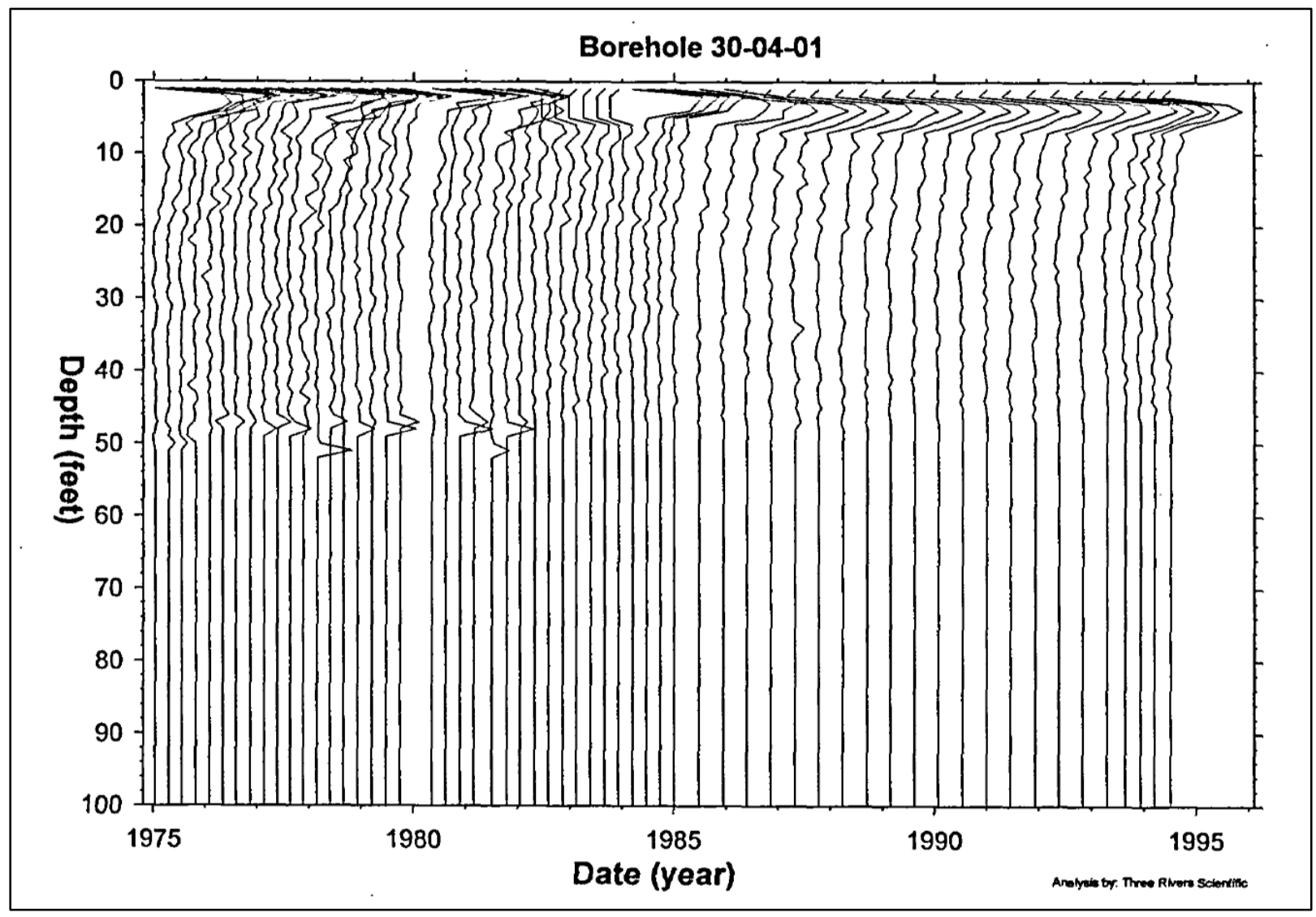

Note: Bottom of the tank footing is $\sim 37$-ft 5 -in BGS 


\subsubsection{Drywell 30-04-02}

Drywell 30-04-02 was drilled in December 1972 with the first recoverable reading on February 7,1973 with a peak of $25 \mathrm{~K} \mathrm{cpm}$ at $41-\mathrm{ft}$ BGS (see 02). Radioactivity gradually increased to approximately $52 \mathrm{~K}$ cpm by June 1974. After June 1974, radioactivity slowly declined and the peak reading was reported as 4.6K cpm at 41-ft BGS on June 19, 1987 (see 02).

In September 1997, Cs-137, Co-60, and U-235 were the only man-made radionuclides detected in drywell 30-04-02 (GJ-HAN-87). Moderate Cs-137 contamination extends from the surface to 2.5-ft BGS, then decreases to less than $20 \mathrm{pCi} / \mathrm{g}$ from 2.5 to 22-ft BGS, and below 22-ft BGS concentrations were less than $1 \mathrm{pCi} / \mathrm{g}$. A thick zone of Co-60 contamination was detected from 38 to 58.5-ft BGS; however, concentrations were less than $1 \mathrm{pCi} / \mathrm{g}$. A single occurrence of U235 was detected at the ground surface $(5.8 \mathrm{pCi} / \mathrm{g})$. The activity peak identified in 1973 at $41-\mathrm{ft}$ BGS correlates to the depth of the Co-60 contamination detected with SGLS (GJ-HAN-87). Document GJ-HAN-87 states the C-104-to-C-105 cascade line leak as the likely source of the Cs-137 and Co-60 detected in this drywell. However, a tank C-105 leak cannot be ruled out. Figure 5-8 shows the depths of radioactivity from 1975 to 1995 (RPP-8321).

Figure 5-8. Tank C-105 Drywell 30-04-02 (RPP-8321)

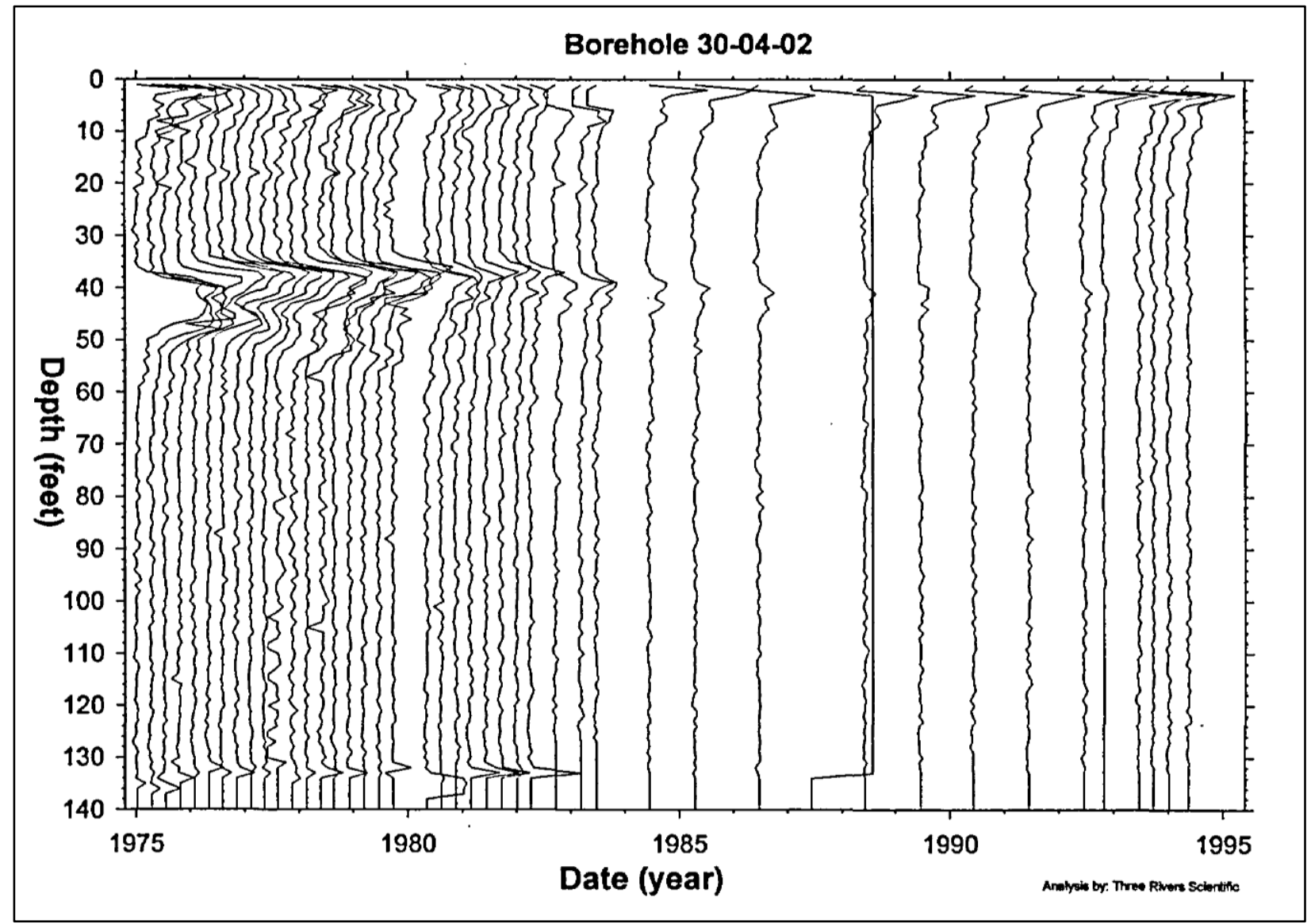

Note: Bottom of the tank footing is $\sim 37$-ft 5 -in BGS 


\subsubsection{Drywell 30-04-03}

Drywell 30-04-03 was drilled in July 1974 with the first recoverable reading reported as $1349.6 \mathrm{~K}$ cpm at 23-ft BGS on August 16, 1974 (see 02). Readings doubled to 2014.4K cpm at 25-ft BGS by December 1974. Readings remained relatively stable to May 1975 and then gradually decreased to $1648 \mathrm{~K}$ cpm at 24-ft BGS by February 4, 1987 (see 02).

In September 1997, Cs-137, Co-60, and U-235 were the only man-made radionuclides detected in drywell 30-04-03 (GJ-HAN-87). Moderate Cs-137 contamination (10 to $50 \mathrm{pCi} / \mathrm{g}$ ) extends from the surface to 3-ft BGS, then decreases to less than $10 \mathrm{pCi} / \mathrm{g}$ below this zone and then to less than $3 \mathrm{pCi} / \mathrm{g}$ below 14-ft BGS. A very distinct zone of Cs-137 contamination occurs between 21 and 26-ft BGS with the highest Cs-137 concentration of $531 \mathrm{pCi} / \mathrm{g}$ detected at $23-\mathrm{ft}$ BGS. Below the large Cs-137 plume, Co-60 was detected continuously from 26-ft BGS to the bottom of the logged interval (49-ft BGS) with concentrations ranging from 3 to $6 \mathrm{pCi} / \mathrm{g}$. A single occurrence of U-235 (4.1 pCi/g) was detected at the ground surface. Document GJ-HAN87 reports, "The distinct zone of high Cs-137 contamination detected between 21 and $26 \mathrm{ft}$ and the extensive plume of Co-60 contamination that underlies it probably resulted from the C-104to-C-105 cascade-line leak. The discrete nature of both contaminant plumes suggests that this borehole lies within proximity of the leak source." However, a tank C-105 leak cannot be ruled out. Figure 5-9 shows the depths of radioactivity from 1980 to 1995 (RPP-8321).

Figure 5-9. Tank C-105 Drywell 30-04-03 (RPP-8321)

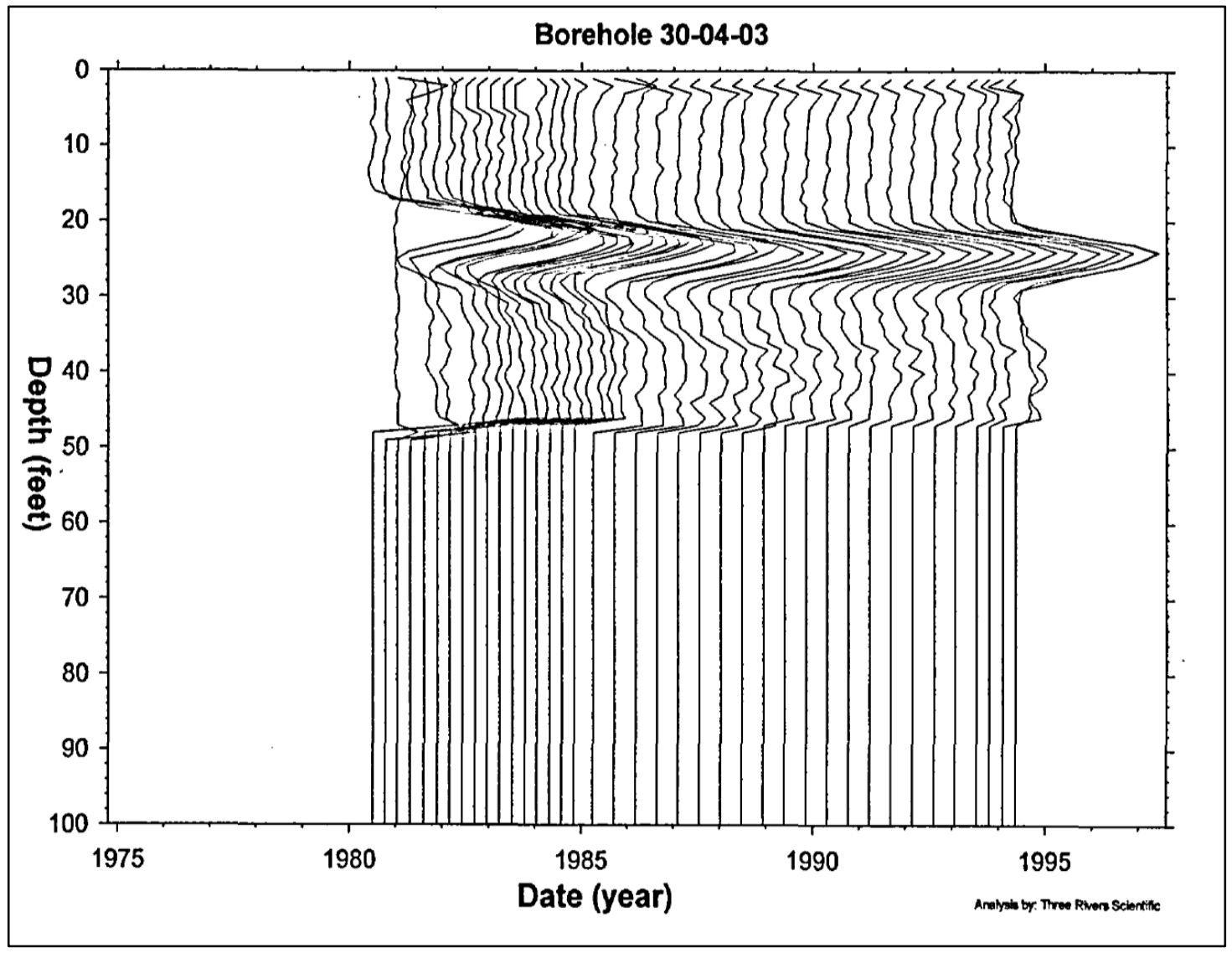

Note: Bottom of the tank footing is $~ 37$-ft 5 -in BGS 


\subsubsection{Drywell 30-04-04}

Drywell 30-04-04 was drilled in June 1974 with the first recoverable reading on June 26, 1974 with a peak of $15.6 \mathrm{~K} \mathrm{cpm}$ at $10-\mathrm{ft}$ BGS (see 02). Readings remained relatively stable at this BGS level until January 24, 1975 when a peak of 5.9K cpm was reported at 21-ft BGS. Readings remained relatively stable through February 1987 (see 02).

In September 1997, Cs-137 was the only man-made radionuclides detected in drywell 30-04-04 (GJ-HAN-87). A near-surface zone of high Cs-137 contamination (up to $1450 \mathrm{pCi} / \mathrm{g}$ ) was measured from the ground surface to 5-ft BGS. From 5 to 22-ft BGS, Cs-137 concentrations ranged from 9 to $14 \mathrm{pCi} / \mathrm{g}$ and from 25 to $44-\mathrm{ft}$ BGS, Cs-137 concentrations decrease to less than $1 \mathrm{pCi} / \mathrm{g}$. A distinct zone of elevated Cs-137 contamination was detected between 45 and 56 - $\mathrm{ft}$ BGS at concentrations ranging from 1 to $4 \mathrm{pCi} / \mathrm{g}$. The Cs- 137 concentrations detected below this zone were less than $0.5 \mathrm{pCi} / \mathrm{g}$ except toward the bottom of the logged interval (98.5-ft BGS) where concentrations increased to $7 \mathrm{pCi} / \mathrm{g}$.

Document GJ-HAN-87 reported, "The distinct zone of elevated Cs-137 contamination detected between 45 and $65 \mathrm{ft}$ may have resulted from the cascade-line leak between tanks C-104 and C105 or possibly from a leak in tank C-101. The contamination detected at this depth may also have migrated downward and laterally from the contaminant source." However, a tank C-105 leak cannot be ruled out. Also, after further analyses it is unlikely the source of radioactivity is from tank C-101 (see tank C-101, Section 4.6). Figure 5-10 shows the depths of radioactivity from 1975 to 1995 (RPP-8321).

Figure 5-10. Tank C-105 Drywell 30-04-04 (RPP-8321)

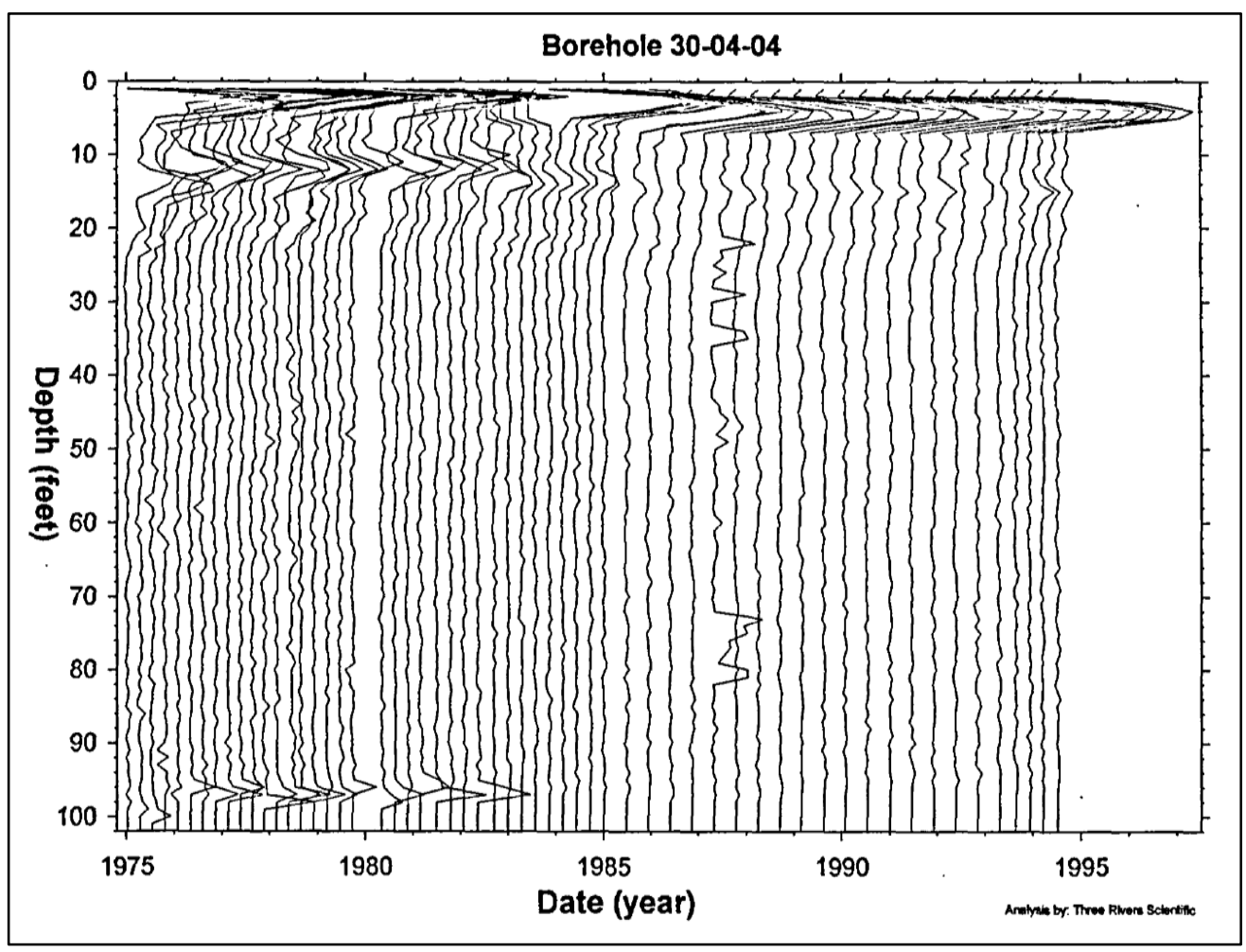

Note: Bottom of the tank footing is $\sim 37$-ft 5-in BGS 
RPP-RPT-54914, Rev. 0

\subsubsection{Drywell 30-04-05}

Drywell 30-04-05 was drilled on July 31, 1974 with the first recoverable reading on September 9, 1974 with a peak of $28.6 \mathrm{~K} \mathrm{cpm}$ at $13-\mathrm{ft}$ BGS (see 02). Radiation levels remained relatively stable and on January 24, 1975 an additional peak was recorded at $3 \mathrm{~K} \mathrm{cpm}$ at 22-ft BGS. The next recoverable reading reported one peak on July 7,1975 at $2.7 \mathrm{~K} \mathrm{cpm}$ at 23 -ft BGS. By February 1976 through February 1987, readings were reported as less than values in drywell 3004-05.

In September 1997, Cs-137 was the only man-made radionuclides detected in drywell 30-04-05 (GJ-HAN-85). From the ground surface to 57.5-ft BGS and from 94.5 to 98.5 -ft BGS, Cs-137 was detected almost continuously with the maximum concentration of $91.5 \mathrm{pCi} / \mathrm{g}$ measured at 12.5-ft BGS. From 69.5 to 91.5-ft BGS, Cs-137 was detected intermittently. Document GJHAN-85 reported, "The Cs-137 contamination from 11 to $38 \mathrm{ft}$ is probably the result of a surface spill that migrated into the backfill material around the borehole" and "The Cs-137 contamination from 45 to $57.5 \mathrm{ft}$ is probably from a tank leak that migrated into the Hanford formation sediments beneath the tank farm excavation." The Cs-137 contamination from 45 to $57.5-\mathrm{ft}$ BGS is below $10 \mathrm{pCi} / \mathrm{g}$ and could be migration from the leak site near tank $\mathrm{C}-101$ drywell 30-01-09. Also, there is no similar Cs-137 peak in drywell 30-04-04 and a leak from tank C-105 should have been detected in both drywells 30-04-04 and 30-05-04 (RPP-ASMT-39801).

Therefore, drywell 30-04-05 is not being included as part of the leak location for tank C-105. Figure 5-11 shows the depths of radioactivity from 1975 to 1995 (RPP-8321).

Figure 5-11. Tank C-105 Drywell 30-04-05 (RPP-8321)

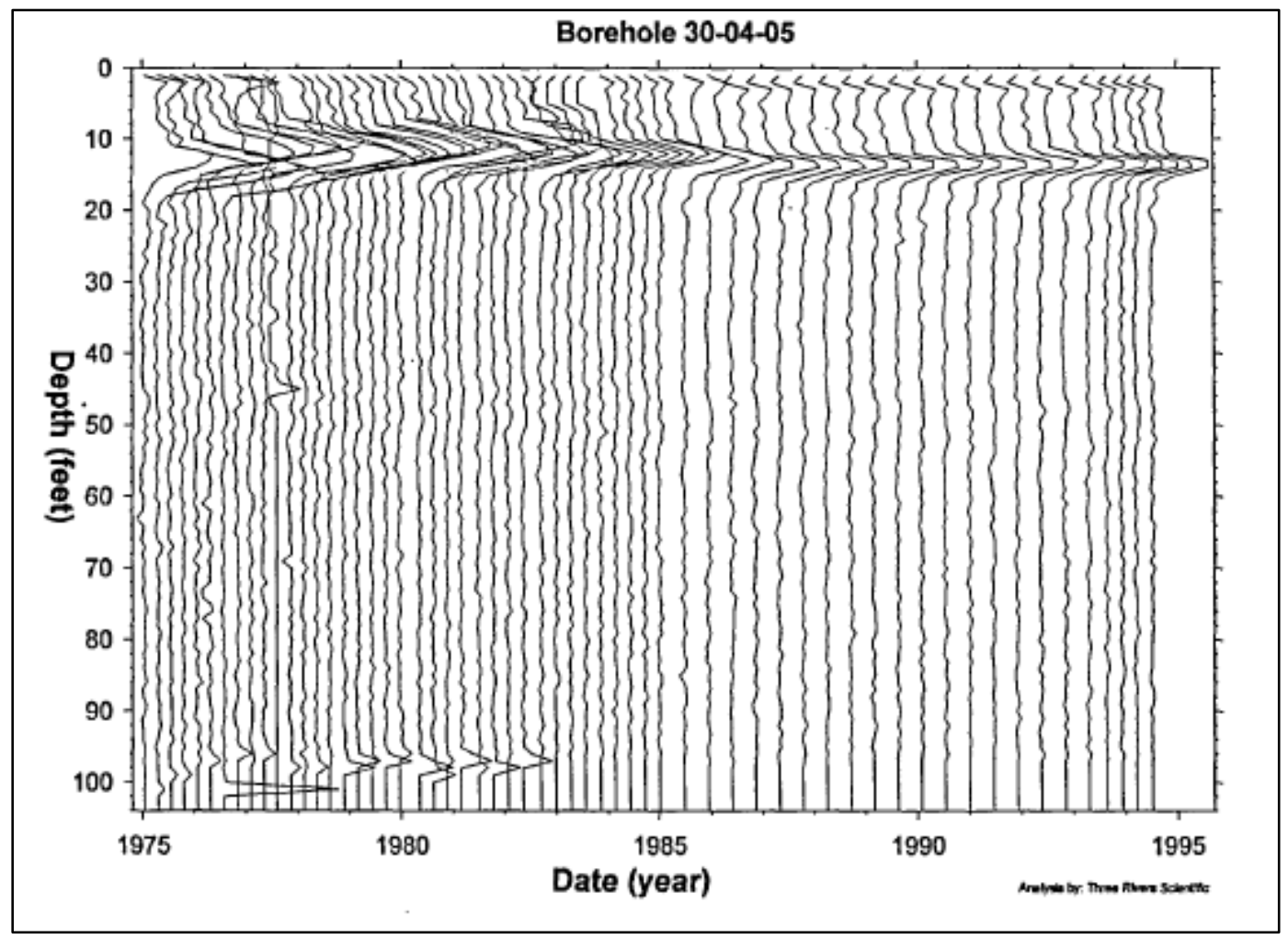

Note: Bottom of the tank footing is $~ 37$-ft 5 -in BGS 
RPP-RPT-54914, Rev. 0

\subsubsection{Drywell 30-04-12}

Drywell 30-04-12 was drilled in December 1972 with the first recoverable reading on March 20, 1973 which reported radioactivity as less than values (see 02). Radioactivity continued to be reported as less than values through February 1987 (see 02).

In September 1997, Cs-137 and Co-60 were the only man-made radionuclides detected in drywell 30-04-12 (GJ-HAN-87). Very low level Cs-137 concentrations (from 0.2 to $0.7 \mathrm{pCi} / \mathrm{g}$ ) were detected from the ground surface to 62-ft BGS with isolated occurrences at $66.5,89$, and 135-ft BGS. A few occurrences of Co-60 contamination were detected at very low concentrations (less than $0.1 \mathrm{pCi} / \mathrm{g}$ ) between 43 and 47.5-ft BGS. Therefore, drywell 30-04-12 is not being included as part of the leak location for tank C-105. Figure 5-12 shows the depths of radioactivity from 1975 to 1995 (RPP-8321).

Figure 5-12. Tank C-105 Drywell 30-04-12 (RPP-8321)

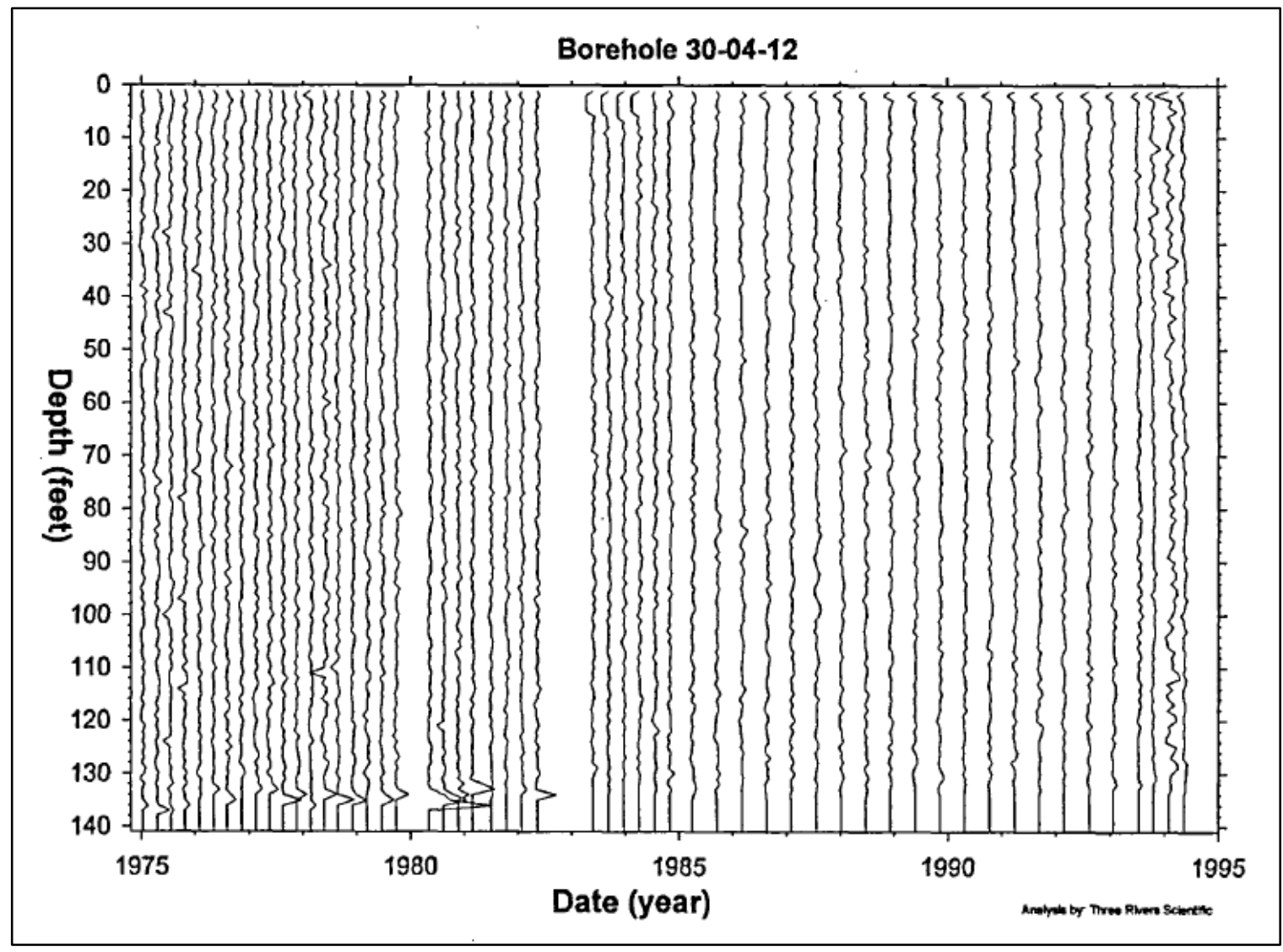

Note: Bottom of the tank footing is $\sim 37$-ft 5 -in BGS 


\subsubsection{Drywell 30-05-02}

Drywell 30-05-02 was drilled in November 1972 with the first recoverable reading on March 20, 1973 with a peak of $15.2 \mathrm{~K} \mathrm{cpm}$ at $22-\mathrm{ft}$ BGS (see 02). Radiation levels gradually declined to 5.9K cpm by March 31, 1987 at 22-ft BGS. From April 1977 to April 1982, the peak was reported at $72-\mathrm{ft}$ BGS at $\sim 5 \mathrm{~K} \mathrm{cpm}$ (see 02).

In August 1997, Cs-137, Co-60, and Eu-154 were the only man-made radionuclides detected in drywell 30-05-02 (GJ-HAN-83). A zone of high Cs-137 concentration (200 to $775 \mathrm{pCi} / \mathrm{g}$ ) was detected from 0.5 to $2-\mathrm{ft}$ BGS, a zone of moderate Cs-137 contamination was detected from 5 to 30-ft BGS, and a very large zone of low Cs-137 concentrations (less than $1 \mathrm{pCi} / \mathrm{g}$ ) was detected from 30-ft BGS to the bottom of the logged interval (127.5-ft BGS). The maximum Co-60 concentration detected was $0.33 \mathrm{pCi} / \mathrm{g}$ at $75-\mathrm{ft} \mathrm{BGS}$. A single occurrence of Eu-154 was detected at the ground surface with a concentration of $1.5 \mathrm{pCi} / \mathrm{g}$. Document GJ-HAN-83 reported, "The Cs-137 contamination detected below about $30 \mathrm{ft}$ was probably carried down during the drilling of this borehole or later migrated down the outside of the borehole casing. The zone of increasing Cs-137 contamination at the bottom of the logged interval is probably from particulate matter that has either fallen down the inside of the borehole or accumulated around the outside of the borehole casing."

The highest Cs-137 readings were encountered at the surface and very low levels were detected at the tank C-105 foundation level, there is no indication of a tank or pipeline leak at this drywell (RPP-ASMT-39801). Therefore, drywell 30-05-02 is not being included as part of the leak location for tank C-105. Figure 5-13 shows the depths of radioactivity from 1975 to 1995 (RPP8321).

Figure 5-13. Tank C-105 Drywell 30-05-02 (RPP-8321)

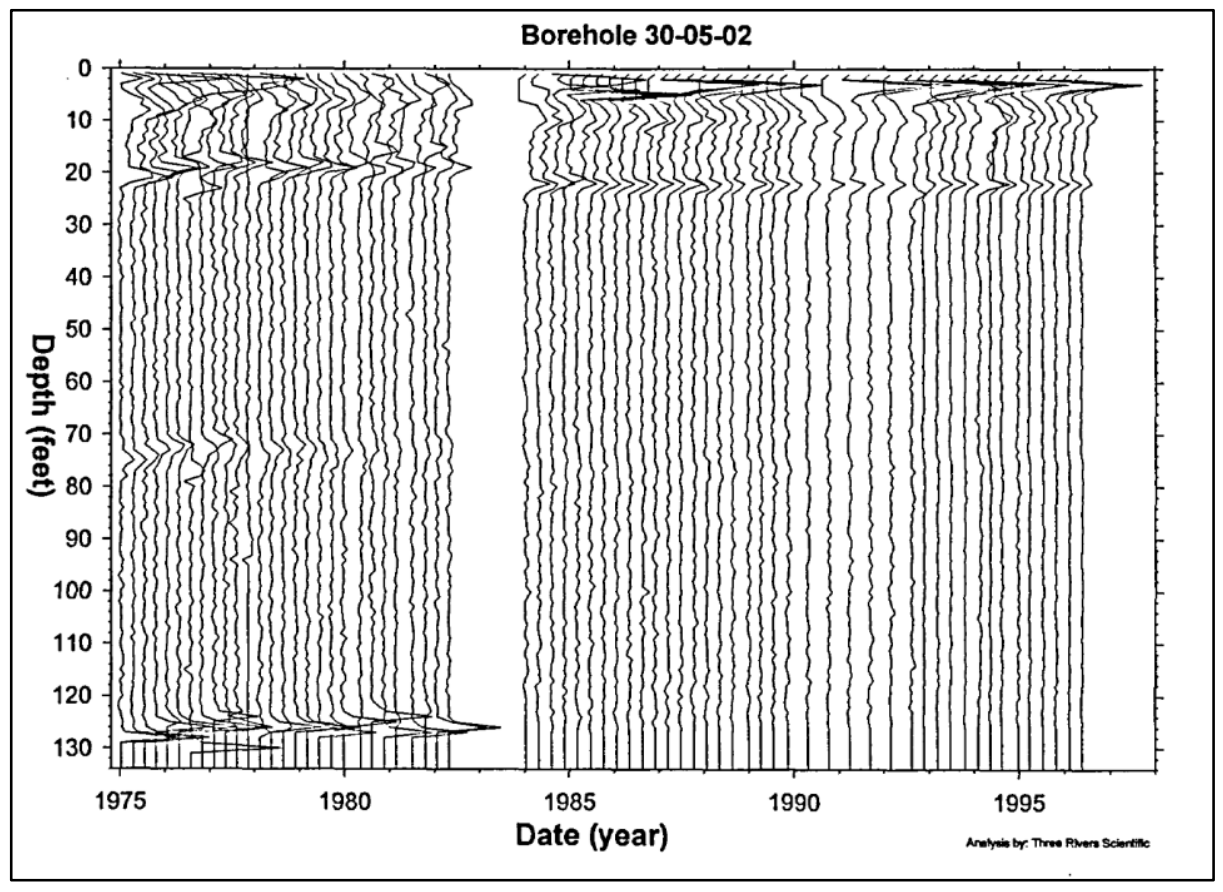

Note: Bottom of the tank footing is $\sim 37$-ft 5 -in BGS 


\subsubsection{Drywell 30-05-03}

Drywell 30-05-03 was drilled in September 1974 with the first recoverable reading on October 25,1974 with a peak of $16.8 \mathrm{~K} \mathrm{cpm}$ at 32-ft BGS (see 02). Radiation levels remained relatively stable at this BGS depth through March 1987 (see 02).

In August 1997, Cs-137 and Co-60 were the only man-made radionuclides detected in drywell 30-05-03 (GJ-HAN-83). From the ground surface to about 35-ft BGS, Cs-137 was detected at concentrations ranging from 10 to $100 \mathrm{pCi} / \mathrm{g}$. From $38-\mathrm{ft} \mathrm{BGS}$ to the bottom of the logged interval (98.5-ft BGS), Cs-137 concentrations of less than $1 \mathrm{pCi} / \mathrm{g}$ were reported. Slightly elevated Co-60 concentrations ranging from about 1 to $2.5 \mathrm{pCi} / \mathrm{g}$ were detected between 73.5 and 75-ft BGS. Document GJ-HAN-83 reported, "The thin, discrete layers of elevated Cs-137 contamination detected at 32 and $35 \mathrm{ft}$ may indicate the accumulation of Cs-137 near the base of the tank farm excavation."..."Much of the Cs-137 contamination detected below about $40 \mathrm{ft}$ was probably carried down during the drilling of this borehole or later migrated down the outside of the borehole casing."..."The continuous zone of Co-60 contamination between 73 and $83 \mathrm{ft}$ may be related to the region of Co-60 contamination detected in borehole 30-05-02. The contamination detected in both boreholes probably represents the remnant of a plume that migrated a considerable distance from the contaminant source."

Drywell 30-05-03 was discounted as being an indication of a tank or pipeline leak since the highest Cs-137 readings were encountered at the surface and very low levels were detected at the tank C-105 foundation level (RPP-ASMT-39801). However, a tank C-105 leak cannot be ruled out. Radioactivity could also be due to a leak from the nearby condenser at the surface followed by dragdown. Figure 5-14 shows the depths of radioactivity from 1975 to 1995 (RPP-8321).

Figure 5-14. Tank C-105 Drywell 30-05-03 (RPP-8321)

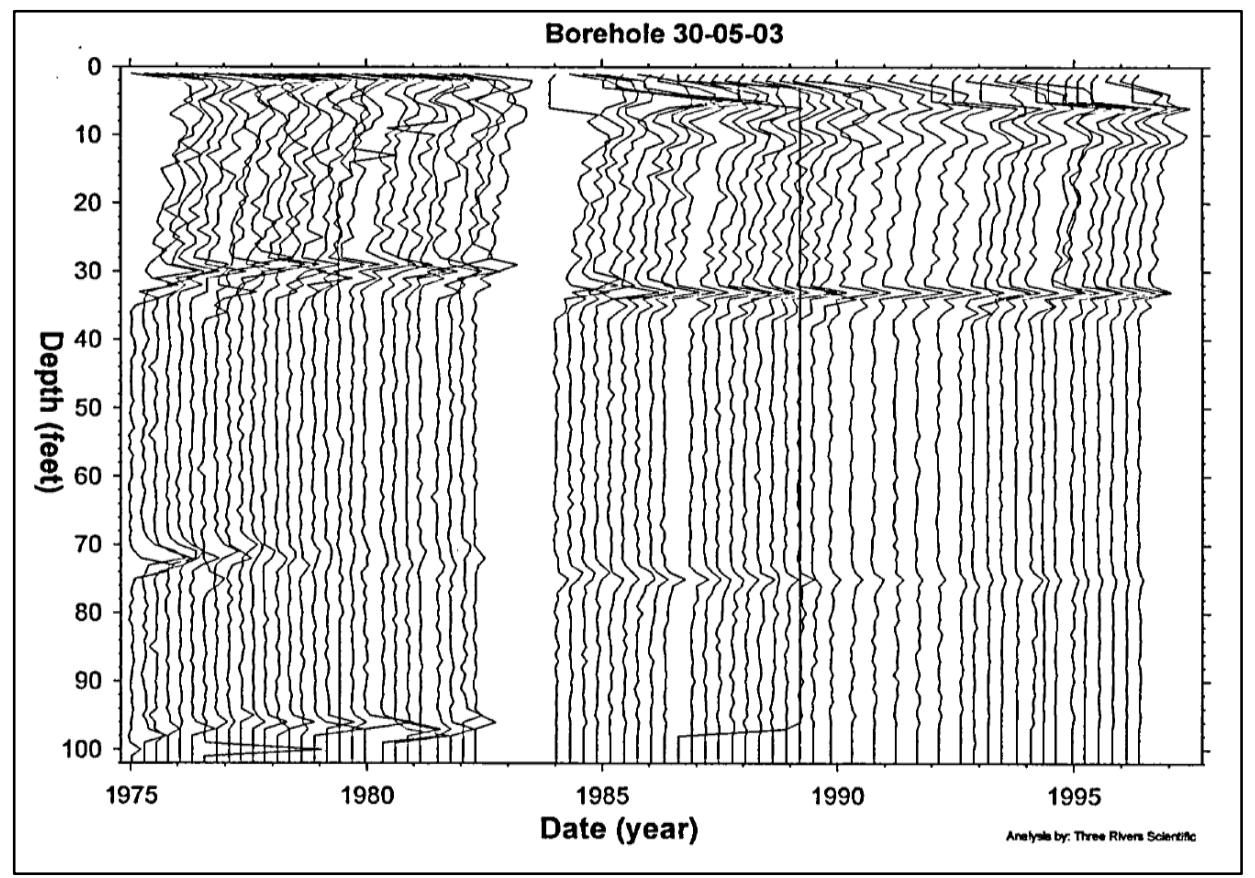

Note: Bottom of the tank footing is $\sim 37$-ft 5 -in BGS 
RPP-RPT-54914, Rev. 0

\subsubsection{Drywell 30-05-04}

Drywell 30-05-04 was drilled in December 1972 with the first recoverable reading on February 7, 1973 reported as less than values (see 02). Radioactivity continued to be reported as less than values through March 1987 (see 02).

In August 1997, Cs-137 and Co-60 were the only man-made radionuclides detected in drywell 30-05-04 (GJ-HAN-83). From the ground surface to 2-ft BGS, Cs-137 concentrations ranged from 25 to $45 \mathrm{pCi} / \mathrm{g}$. The Cs- 137 contamination decreases to less than $5 \mathrm{pCi} / \mathrm{g}$ between 5 and 16-ft BGS and then gradually decreases to 103-ft BGS. The Co-60 concentrations detected in this drywell were very low, ranging from 0.1 to $0.2 \mathrm{pCi} / \mathrm{g}$. Document GJ-HAN-83 reported, "Much of the Cs-137 contamination detected below about $16 \mathrm{ft}$ was probably carried down during the drilling of this borehole or later migrated down the outside of the borehole casing." The highest Cs-137 readings were encountered at the surface and very low levels were detected at the tank C-105 foundation level, there is no indication of a tank or pipeline leak at this drywell (RPP-ASMT-39801). Therefore, drywell 30-05-04 is not being included as part of the leak location for tank C-105. Figure 5-15 shows the depths of radioactivity from 1975 to 1995 (RPP8321).

Figure 5-15. Tank C-105 Drywell 30-05-04 (RPP-8321)

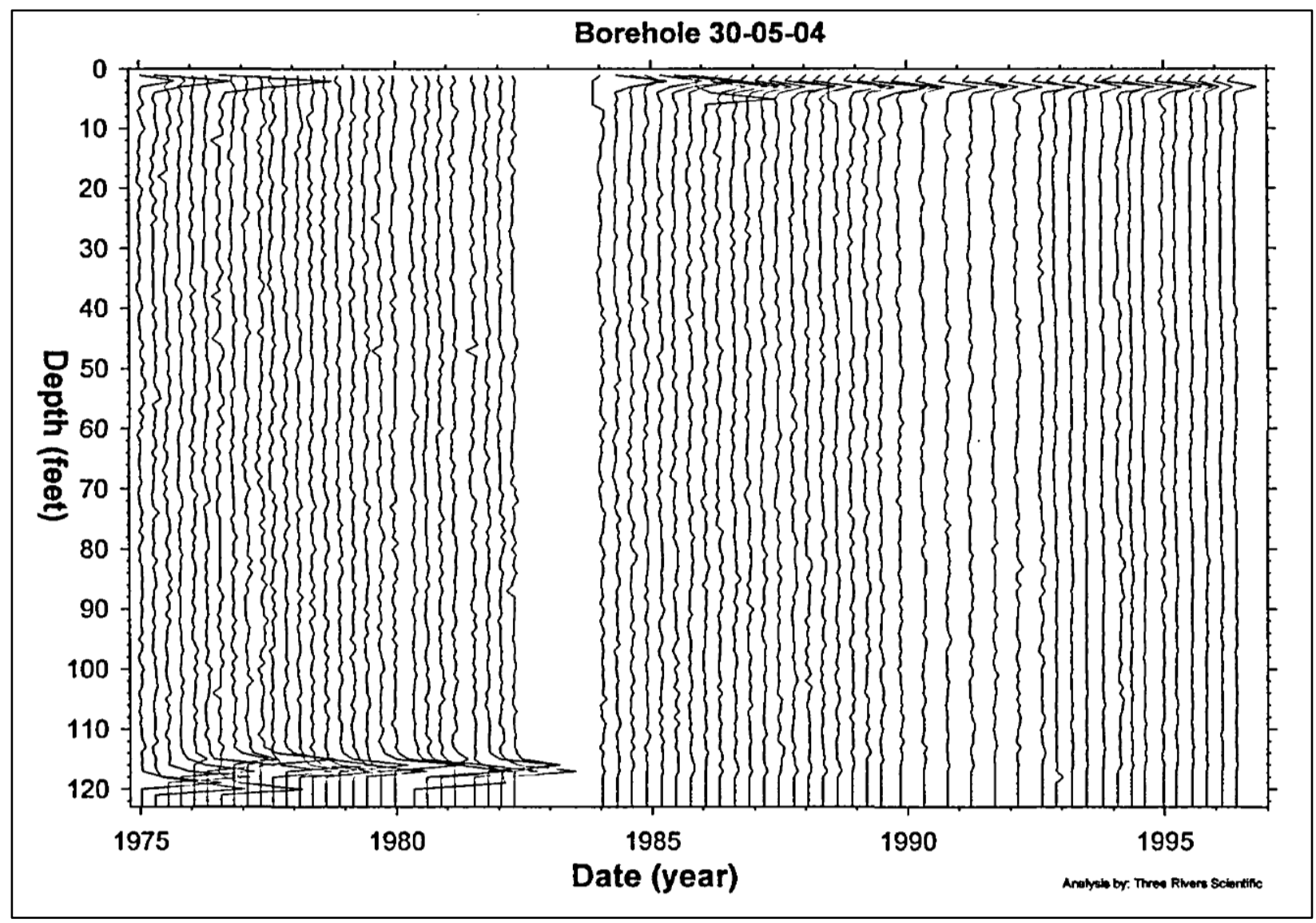

Note: Bottom of the tank footing is $\sim 37$-ft 5-in BGS 
RPP-RPT-54914, Rev. 0

\subsubsection{Drywell 30-05-05}

Drywell 30-05-05 was drilled in June 1974 with the first recoverable reading on July 3, 1974 with a peak of $20.9 \mathrm{~K} \mathrm{cpm}$ at $64-\mathrm{ft}$ BGS (see 02 ). Radiation levels gradually declined to $14.2 \mathrm{~K}$ cpm by March 31, 1987 at 65-ft BGS (see 02).

In August 1997, Cs-137 and Co-60 were the only man-made radionuclides detected in drywell 30-05-05 (GJ-HAN-83). From the ground surface to 84.5-ft BGS, relatively higher Cs-137 concentrations were detected with the highest concentration $(161 \mathrm{pCi} / \mathrm{g})$ reported at the ground surface. The Cs-137 concentrations ranged from 30 to $70 \mathrm{pCi} / \mathrm{g}$ between 60 and 66-ft BGS. Continuous Co-60 contamination was detected from 69.5 to $74.5-\mathrm{ft}$ BGS (as much as $1 \mathrm{pCi} / \mathrm{g}$ ). A few Co-60 occurrences were detected at very low concentrations $(0.1 \mathrm{pCi} / \mathrm{g})$ at $79,79.5$, and 97-ft BGS. Document GJ-HAN-83 reported, "On the basis of an assessment of the RLS data, Brodeur (1993) concludes that there are two possible sources for the high Cs-137: lateral migration of the radionuclides released in the C-104-to-C-105 cascade-line leak, or a leak from tank C-105." However, radioactivity is detected at a much lower BGS level than the other nearby drywells and could be migration from an unknown source. Therefore, drywell 30-05-05 is not being included as part of the leak location for tank C-105. Figure 5-16 shows the depths of radioactivity from 1975 to 1995 (RPP-8321).

Figure 5-16. Tank C-105 Drywell 30-05-05 (RPP-8321)

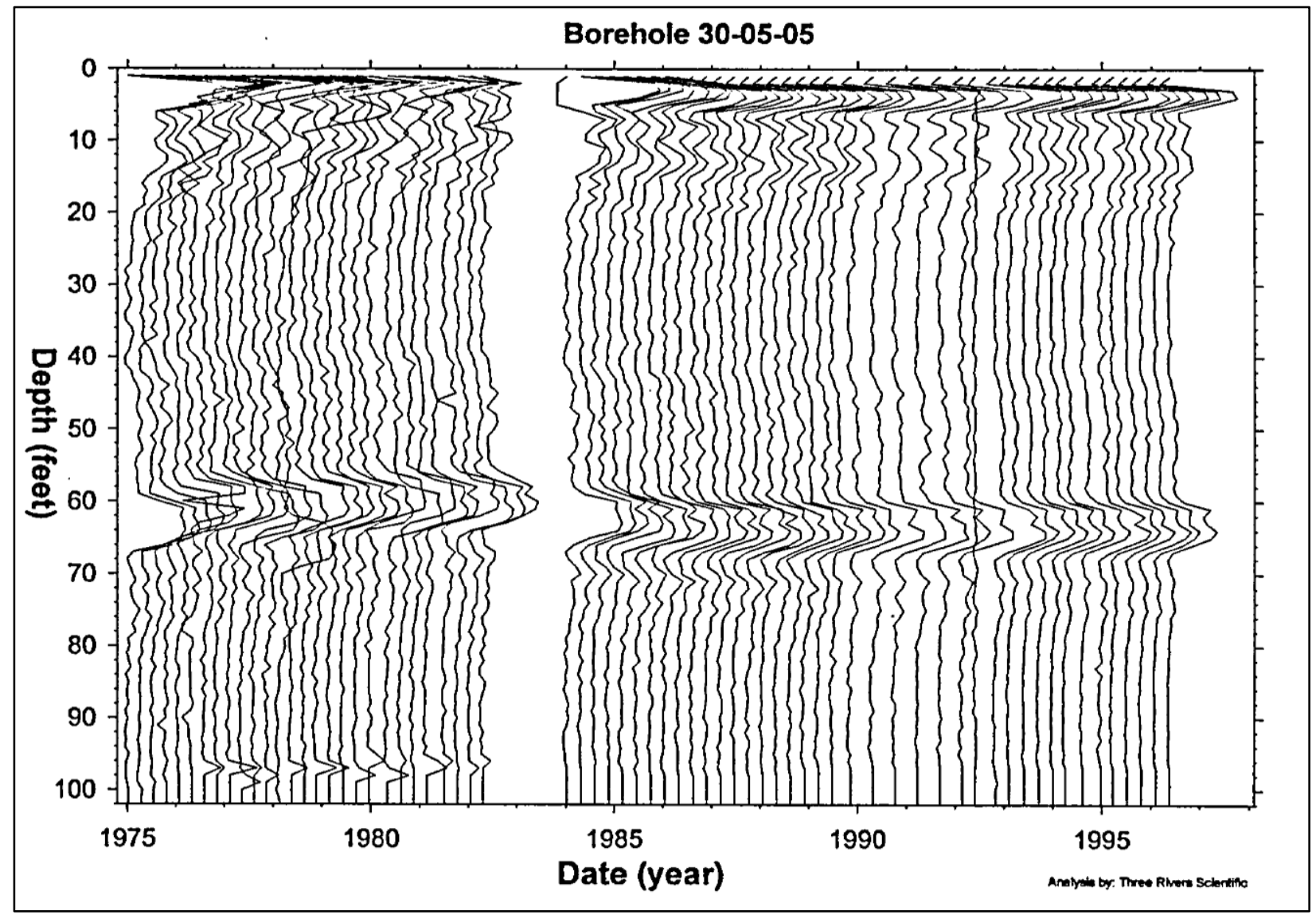

Note: Bottom of the tank footing is $\sim 37$-ft 5-in BGS 


\subsubsection{Drywell 30-05-06}

Drywell 30-05-06 was drilled in July 1974 with the first recoverable reading on August 16, 1974 with a peak of $7.2 \mathrm{~K} \mathrm{cpm}$ at 43 -ft BGS (see 02 ). Radiation levels gradually declined to $2.3 \mathrm{~K}$ cpm by April 11, 1979. From April 1981 through March 1987, radioactivity was reported as less than values indicating earlier peaks reported were due to short-lived radioisotopes (see 02).

In August 1997, Cs-137 and U-235 were the only man-made radionuclides detected in drywell 30-05-06 (GJ-HAN-83). From the ground surface to 2-ft BGS, Cs-137 concentrations ranged from 10 to $30 \mathrm{pCi} / \mathrm{g}$. The Cs-137 contamination decreases to less than $10 \mathrm{pCi} / \mathrm{g}$ below this zone and continues to decrease to less than $1 \mathrm{pCi} / \mathrm{g}$ below 26-ft BGS. Between 41 and 52-ft BGS, Cs137 concentrations ranged from 0.5 to $1 \mathrm{pCi} / \mathrm{g}$ and contamination was slightly above the minimum detection limit (MDL) at 35.5 and 36.5-ft BGS. A single occurrence of U-235 was detected at the ground surface with a concentration slightly above the MDL at $3.6 \mathrm{pCi} / \mathrm{g}$. Document GJ-HAN-83 reported, "The zone of Cs-137 contamination between 41 and $52 \mathrm{ft}$ may have resulted from the cascade-line leak between tanks C-104 and C-105."..."The low Cs-137 concentrations contamination detected below 26 and $52 \mathrm{ft}$ were probably carried down during drilling of this borehole or later migrated down the outside of the borehole casing." Therefore, drywell 30-05-06 is not being included as part of the leak location for tank C-105. However, a pipeline leak cannot be ruled out. Figure 5-17 shows the depths of radioactivity from 1975 to 1995 (RPP-8321).

Figure 5-17. Tank C-105 Drywell 30-05-06 (RPP-8321)

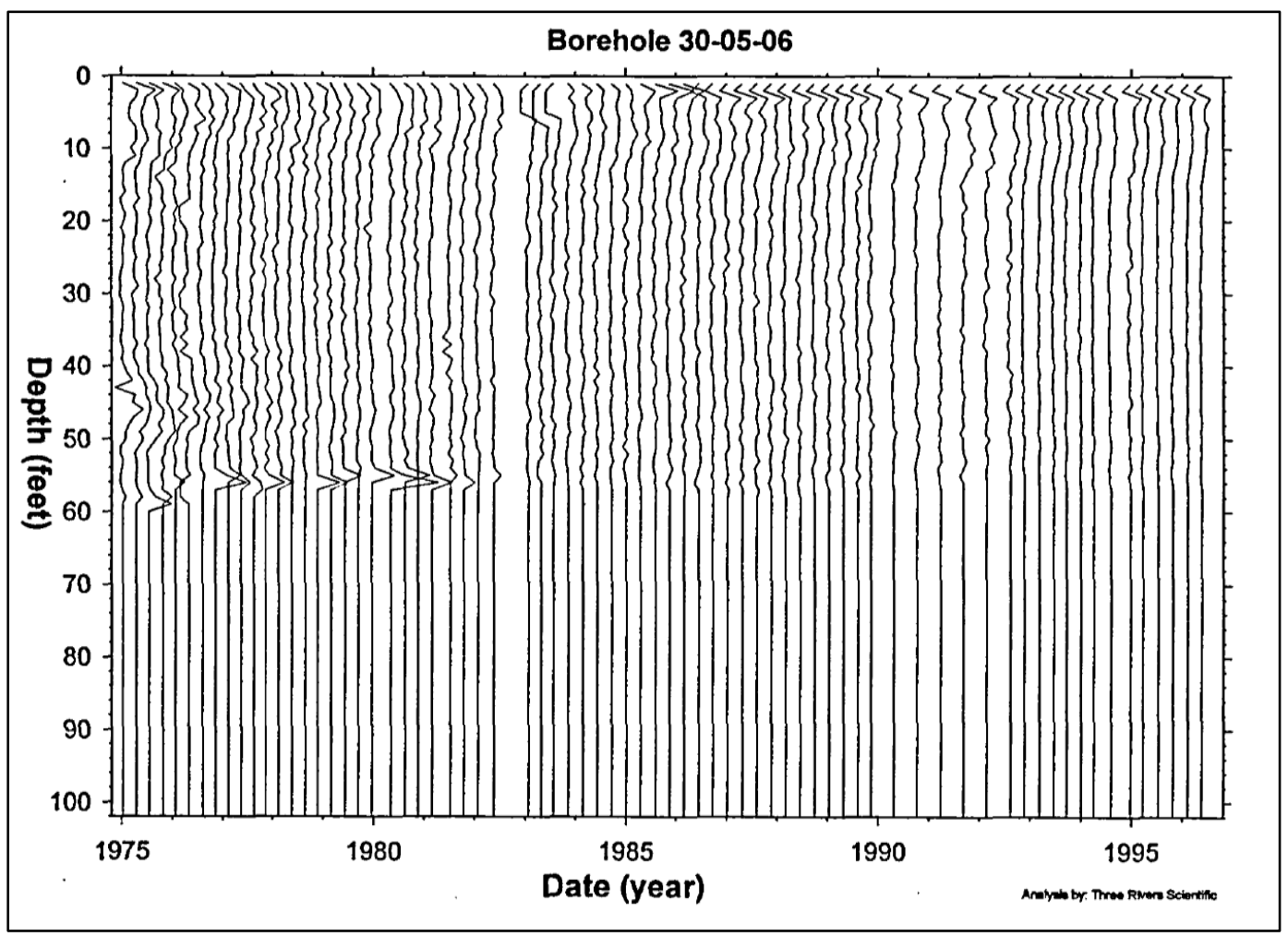

Note: Bottom of the tank footing is $\sim 37$-ft 5 -in BGS 


\subsubsection{Drywell 30-05-07}

Drywell 30-05-07 was drilled in July 1974 with the first recoverable reading on August 15, 1974 with a peak of $837.4 \mathrm{~K} \mathrm{cpm}$ at $37-\mathrm{ft}$ BGS (see 02). Radiation levels remained relatively stable through June 2, 1980 with a peak of $878.9 \mathrm{~K}$ cpm reported at $35-\mathrm{ft}$ BGS. A change in the GM probe resulted in the next reading on June 16,1980 reported at $332.8 \mathrm{~K} \mathrm{cpm}$ at $35-\mathrm{ft} \mathrm{BGS}$. Readings remained relatively stable through April 1987 (see 02).

In August 1997, Cs-137, Co-60, Eu-152, Eu-154, and U-235 were the only man-made radionuclides detected in drywell 30-05-07 (GJ-HAN-83). A region of high Cs-137 contamination ( 75 to $300 \mathrm{pCi} / \mathrm{g}$ ) was detected from 1 to $11-\mathrm{ft}$ BGS. The concentration gradually decreases to less than $2 \mathrm{pCi} / \mathrm{g}$ between 11 and 18-ft BGS. A region of extremely high Cs-137 contamination $(3,000$ to $4,500 \mathrm{pCi} / \mathrm{g})$ was detected between 33.5 and $65-\mathrm{ft}$ BGS and concentrations could exceed $4,500 \mathrm{pCi} / \mathrm{g}$ due to high dead time or detector saturation.

An isolated occurrence of Co-60 (0.16 pCi/g) was detected at 28.5-ft BGS and continuous Co-60 contamination was detected from 65 to 66.5 -ft BGS at concentrations slightly higher than 1 $\mathrm{pCi} / \mathrm{g}$. The Eu-152 contamination was detected at the ground surface $(12.5 \mathrm{pCi} / \mathrm{g})$ and at $65.5-\mathrm{ft}$ BGS (43.4 pCi/g). The Eu-154 contamination was detected at 27.5, 32.5, and 65.5-ft BGS at concentrations of $8,77.5$, and $30.6 \mathrm{pCi} / \mathrm{g}$, respectively.

The measured Cs-137 in this drywell was a factor of nearly $10^{6}$ times higher than any other measurements from other tank C-104 or C-105 drywells with the highest concentrations at the tank footing. Historical gross gamma scans have interpreted the peak in drywell 30-05-07 as stable and decaying with a Cs-137 half-life; however, the validity of the interpretation that the peak is stable is affected by the radiation detector counting limitations (RPP-ASMT-39801, Section 7.7). Figure 5-18 shows the depths of radioactivity from 1980 to 1995 (RPP-8321).

Figure 5-18. Tank C-105 Drywell 30-05-07 (RPP-8321)

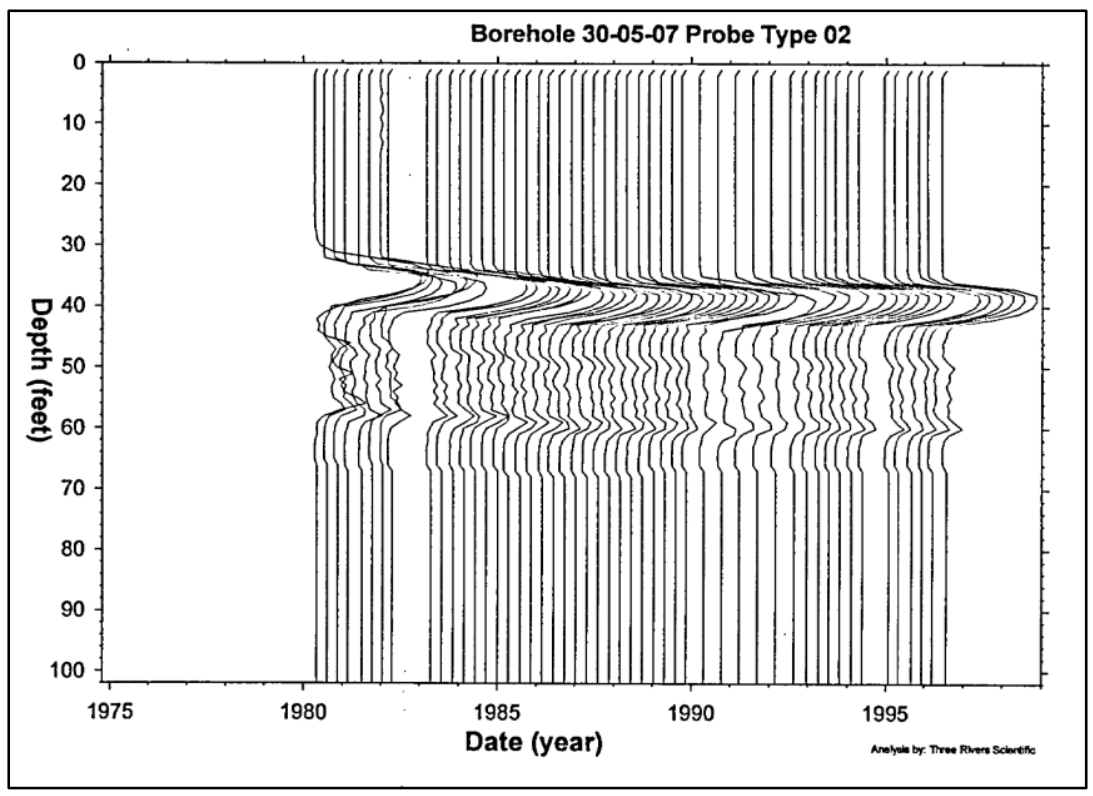

Note: Bottom of the tank footing is $\sim 37-\mathrm{ft} 5$-in BGS 


\subsubsection{Drywell 30-05-08}

Drywell 30-05-08 was drilled in July 1974 with the first recoverable reading on August 16, 1974 with a peak of $235.6 \mathrm{~K} \mathrm{cpm}$ at $16-\mathrm{ft}$ BGS (see 02). The next recoverable reading reported a peak at this BGS depth on January 10, 1975. However, beginning on January 24, 1975 a new peak $(85.9 \mathrm{~K} \mathrm{cpm})$ was reported at 39-ft BGS. Radioactivity then slowly declined and by March 31 , 1987, a peak of 3.9K cpm was reported at 39-ft BGS (see 02).

In August 1997, Cs-137, Co-60, and Eu-154 were the only man-made radionuclides detected in drywell 30-05-08 (GJ-HAN-83). Three distinct zones of elevated Cs-137 concentrations were reported: from 1 to 7 -ft BGS (concentrations ranged from 50 to $125 \mathrm{pCi} / \mathrm{g}$ ), from 15 to $20-\mathrm{ft}$ BGS ( 10 to $70 \mathrm{pCi} / \mathrm{g}$ ), and from 45 to 47.5 -ft BGS (10 to $15 \mathrm{pCi} / \mathrm{g}$ ). The Co-60 contamination was detected from 2.5 to $3-\mathrm{ft}, 15.5$ to $17-\mathrm{ft}$, and 34.5 to $48.5-\mathrm{ft}$ BGS, however, concentrations were generally less than $0.5 \mathrm{pCi} / \mathrm{g}$ except from 37.5 to $39-\mathrm{ft}$ BGS where concentrations ranged from 0.75 to $2 \mathrm{pCi} / \mathrm{g}$. The Eu-154 contamination was detected from 14.5 to 18.5 -ft BGS with concentrations up to $20 \mathrm{pCi} / \mathrm{g}$.

Document GJ-HAN-83 reported, “A significant zone of Cs-137 and Eu-154 contamination combined with low levels of Co-60 contamination was detected between 14 and $20 \mathrm{ft}$. This contamination probably resulted from a transfer-line leak because it occurs at a relatively shallow depth above the level of the cascade line between tanks C-104 and C-105." It was also stated that the Cs-137 and Co-60 detected deeper in the drywell were likely the result of subsurface contamination from the C-104-to-C105 cascade line leak. However, a tank C-105 leak cannot be ruled out. A leak from the capped spare nozzles was ruled out as source of radioactivity detected in drywell 30-05-08 (RPP-ASMT-46452). Figure 5-19 shows the depths of radioactivity from 1975 to 1995 (RPP-8321).

Figure 5-19. Tank C-105 Drywell 30-05-08 (RPP-8321)

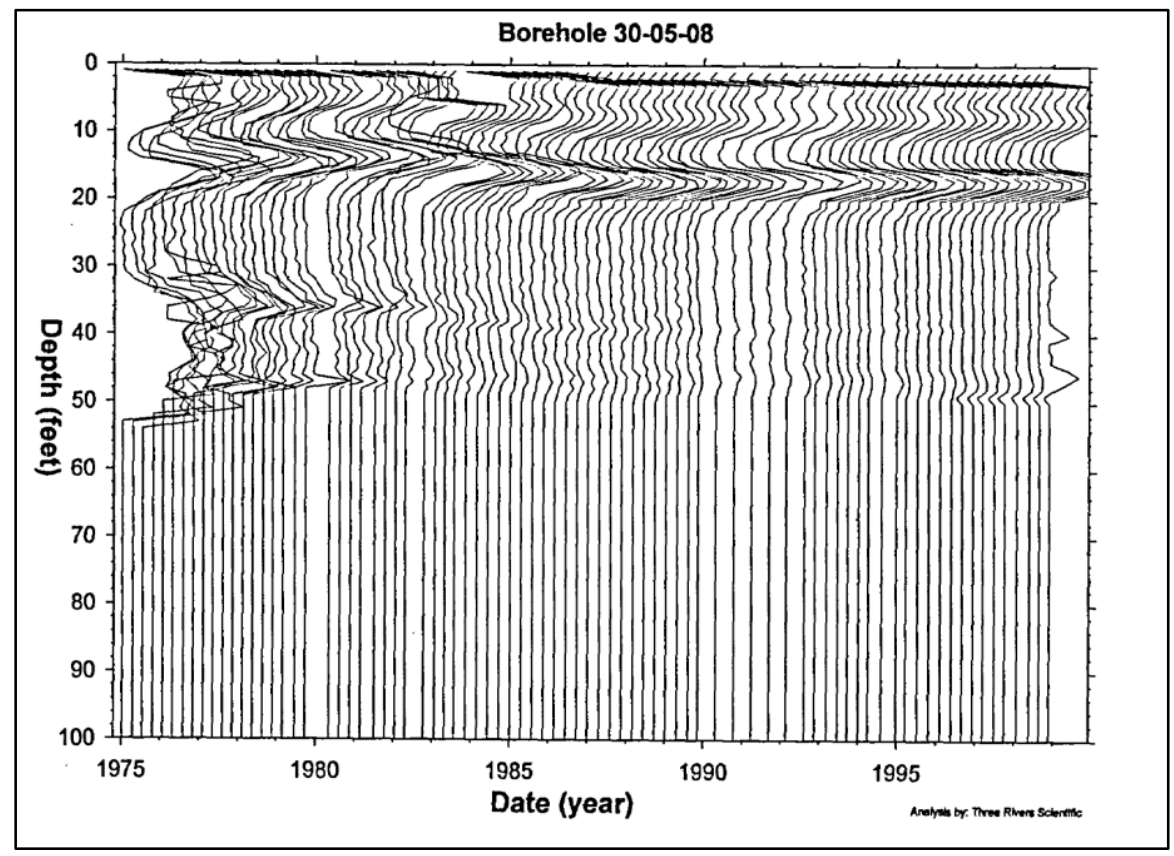

Note: Bottom of the tank footing is $\sim 37$-ft 5 -in BGS 


\subsubsection{Drywell 30-05-09}

Drywell 30-05-09 was drilled in June 1974 with the first recoverable reading on June 26, 1974 which reported radioactivity as less than values (see 02). Readings continued to be reported as less than values through March 1987 (see 02).

In August 1997, Cs-137 was the only man-made radionuclides detected in drywell 30-05-09 (GJHAN-83). A thick zone of generally low Cs- 137 contamination, with concentrations decreasing with depth (from 7 to $0.2 \mathrm{pCi} / \mathrm{g}$ ), were reported from the ground surface to $32.5-\mathrm{ft}$ BGS. From 48.5 to $77-\mathrm{ft}$ BGS concentrations were less than $0.5 \mathrm{pCi} / \mathrm{g}$, except from 57 to $64-\mathrm{ft}$ BGS concentrations were greater than $1 \mathrm{pCi} / \mathrm{g}$. Document GJ-HAN-83 reported, "The majority of the shallow Cs-137 contamination detected between the ground surface and $27 \mathrm{ft}$ probably resulted from surface spills that have migrated down into the backfill surrounding the borehole. The region of elevated Cs-137 contamination detected from 58 to $63 \mathrm{ft}$ suggests the possibility of a subsurface source, such as the C-104-to-C-105 cascade-line leak." Therefore, drywell 30-05-09 is not being included as part of the leak location for tank C-105. Figure 5-20 shows the depths of radioactivity from 1975 to 1995 (RPP-8321).

Figure 5-20. Tank C-105 Drywell 30-05-09 (RPP-8321)

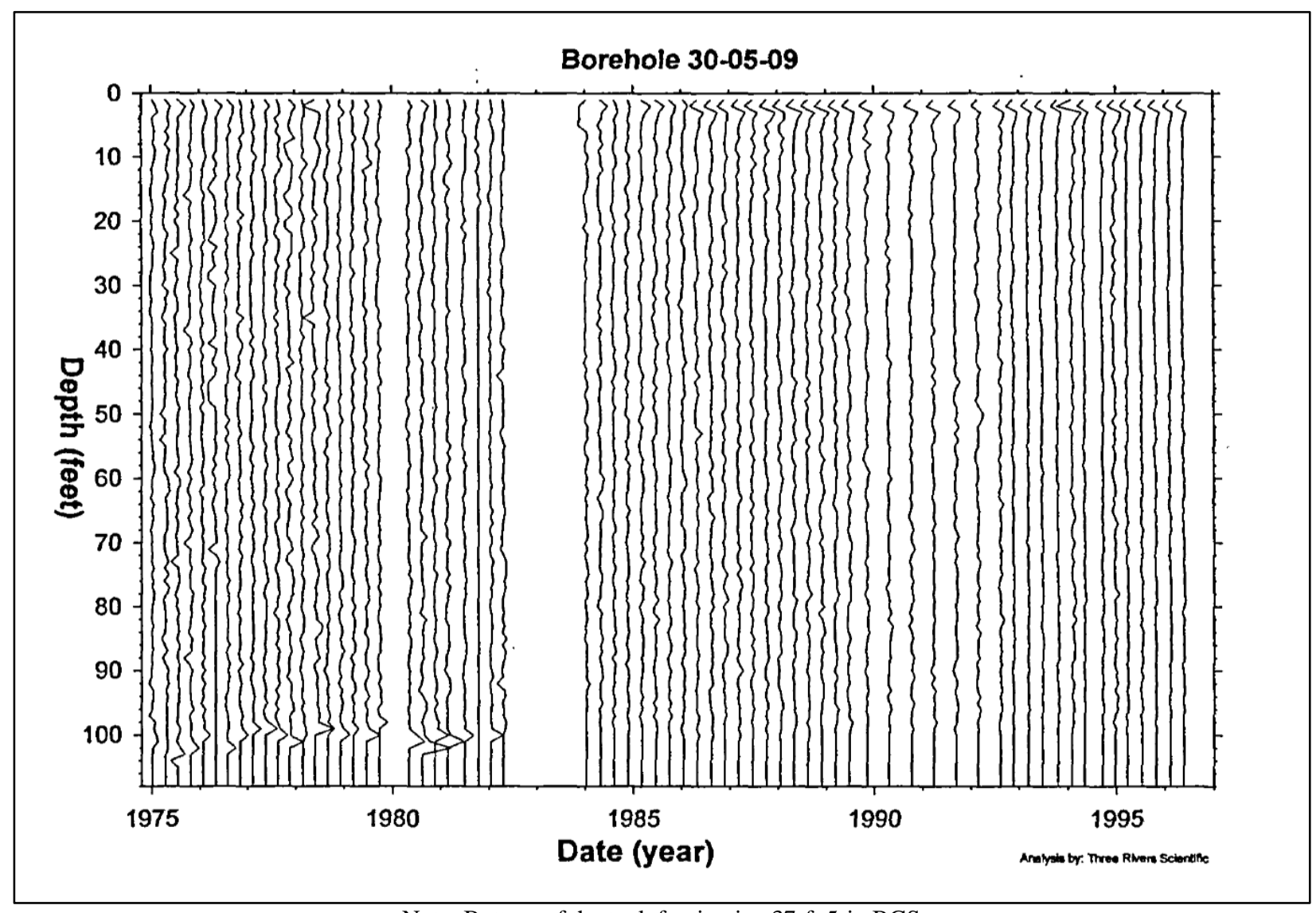

Note: Bottom of the tank footing is 37-ft 5-in BGS 


\subsubsection{Drywell 30-05-10}

Drywell 30-05-10 was drilled in November 1972 with the first recoverable reading on February 7,1973 with a peak of $12 \mathrm{~K} \mathrm{cpm}$ at a depth not recorded (see 02). The next recoverable reading reported a peak of $5.5 \mathrm{~K} \mathrm{cpm}$ at 20-ft BGS on April 26, 1974. Readings slowly declined to 2.6K cpm by April 9, 1980 at 21-ft BGS. From April 1980 through March 1987, radioactivity was reported as less than values indicating the earlier readings were likely due to short-lived radioisotopes (see 02).

In August 1997, Cs-137, Co-60, and U-235 were the only man-made radionuclides detected in drywell 30-05-10 (GJ-HAN-83). From the ground surface to 16-ft BGS, and concentrations decreasing with depth, Cs-137 concentrations ranged from 0.2 to $3 \mathrm{pCi} / \mathrm{g}$. Small regions of very low Cs-137 contamination (less than $0.6 \mathrm{pCi} / \mathrm{g}$ ) were reported from 26 to $30-\mathrm{ft}$ and 114.5 to 116.5-ft BGS, and from 134.5 to 135.5 -ft BGS concentrations were between 0.25 and $2.5 \mathrm{pCi} / \mathrm{g}$. Several small zones of Co-60 contamination were detected between 13 and 53.5-ft BGS at concentrations less than $0.25 \mathrm{pCi} / \mathrm{g}$. Document GJ-HAN-83 reported, "Most of the Cs-137 contamination detected below $20 \mathrm{ft}$ was probably carried down during the drilling of this borehole or later migrated down the outside of the borehole casing." and "The zones of Co-60 contamination detected from 13 to $14.5 \mathrm{ft}$ and 23 to $26 \mathrm{ft}$ may have resulted from a nearby pipeline leak. The isolated region of minor Co-60 contamination detected from 47 to $53.5 \mathrm{ft}$ may represent the remnant of a plume related to the cascade-line leak that occurred between tanks C104 and C-105." Therefore, drywell 30-05-10 is not being included as part of the leak location for tank C-105. Figure 5-21 shows the depths of radioactivity from 1975 to 1995 (RPP-8321).

Figure 5-21. Tank C-105 Drywell 30-05-10 (RPP-8321)

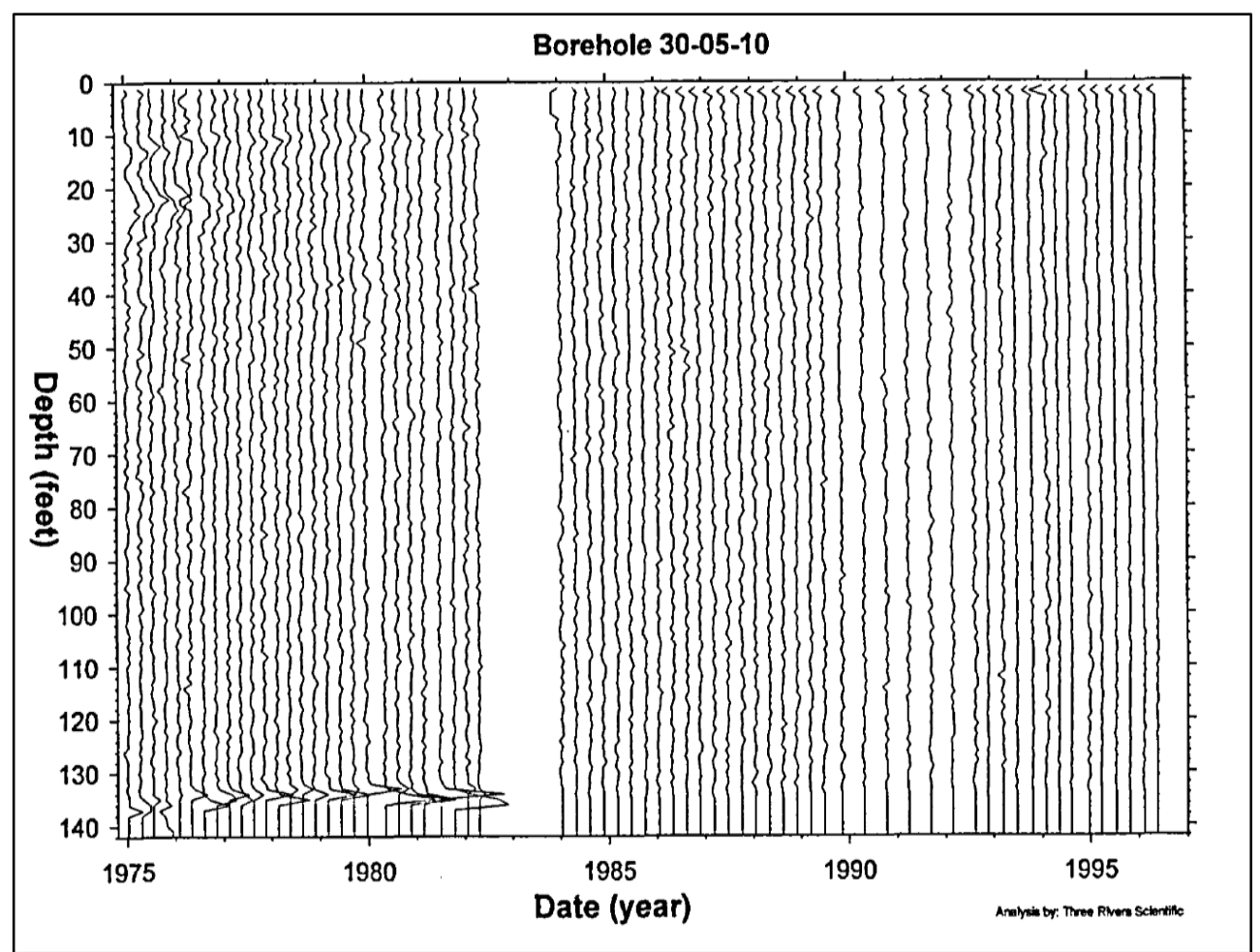

Note: Bottom of the tank footing is $\sim 37$-ft 5 -in BGS 
RPP-RPT-54914, Rev. 0

\subsubsection{Drywell C4297 and Direct Push C7469}

\section{$\underline{\mathrm{C4297}}$}

In February 2004, drywell C4297 was installed to a total depth of 196.5-ft BGS between tanks C104 and C-105 (see Figure 5-1). Results of the spectral gamma logging (see Figure 5-22) show elevated Cs-137 contamination between 10 and 20-ft BGS with a sharp peak at 14-ft BGS $(\sim 1000 \mathrm{pCi} / \mathrm{g})$. A Eu-154 peak ( 150 pCi/g) was also reported at 14-ft BGS which suggests a point source contamination, such as a pipeline. Line V103 that connects to tank C-105 lies less than 6-in from drywell C4297 at a depth of 13.6-ft BGS (RPP-ASMT-39801, Rev. 1). From 40 to 65 -ft BGS, Co-60 is present at concentrations up to $0.5 \mathrm{pCi} / \mathrm{g}$ which is similar to drywell 30 05-08. It was reported in RPP-35484, Rev. 1, “At least two waste sources initiating at different starting depths and likely different times in the vadose zone are inferred from these observations, consistent with a tank leak event and at least one transfer line leak event."

Figure 5-22. Spectral Gamma Analyses of Drywell C4297 RPP-35484, Rev. 1

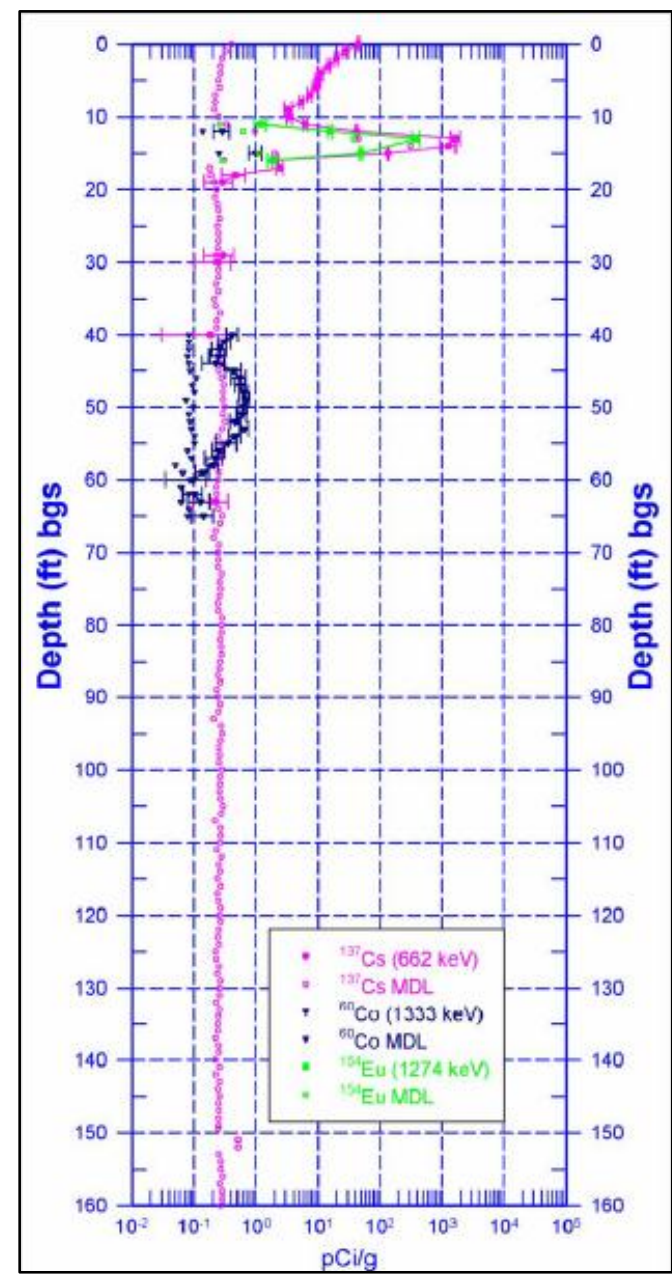

$\mathrm{MDL}=$ minimum detection limit Note: Bottom of the tank footing is $\sim 37$-ft 5 -in BGS 


\section{C7469}

Direct push C7469 was installed in October 2009 and is located 3.8-ft from the inlet cascade line sidewall penetration, 2.3-ft from the tank sidewall, and pushed down to the tank footing (see Figure 5-1). A sodium iodide detector was used until the detector became saturated due to high count rates (about 23.5-ft BGS) and then a lower sensitivity green GM detector was used to complete the logging (see Figure 5-23). At 28-ft BGS, a peak concentration of $\sim 1 \times 10^{6} \mathrm{pCi} / \mathrm{g}$ was reported (see Figure 5-23) which is similar to concentrations reported beneath the spare inlet penetrations during the 1967 excavation for Line V103 (RPP-RPT-43725).

\section{Figure 5-23. Direct Push C7469 Small Diameter Gamma Survey RPP-RPT-43725}

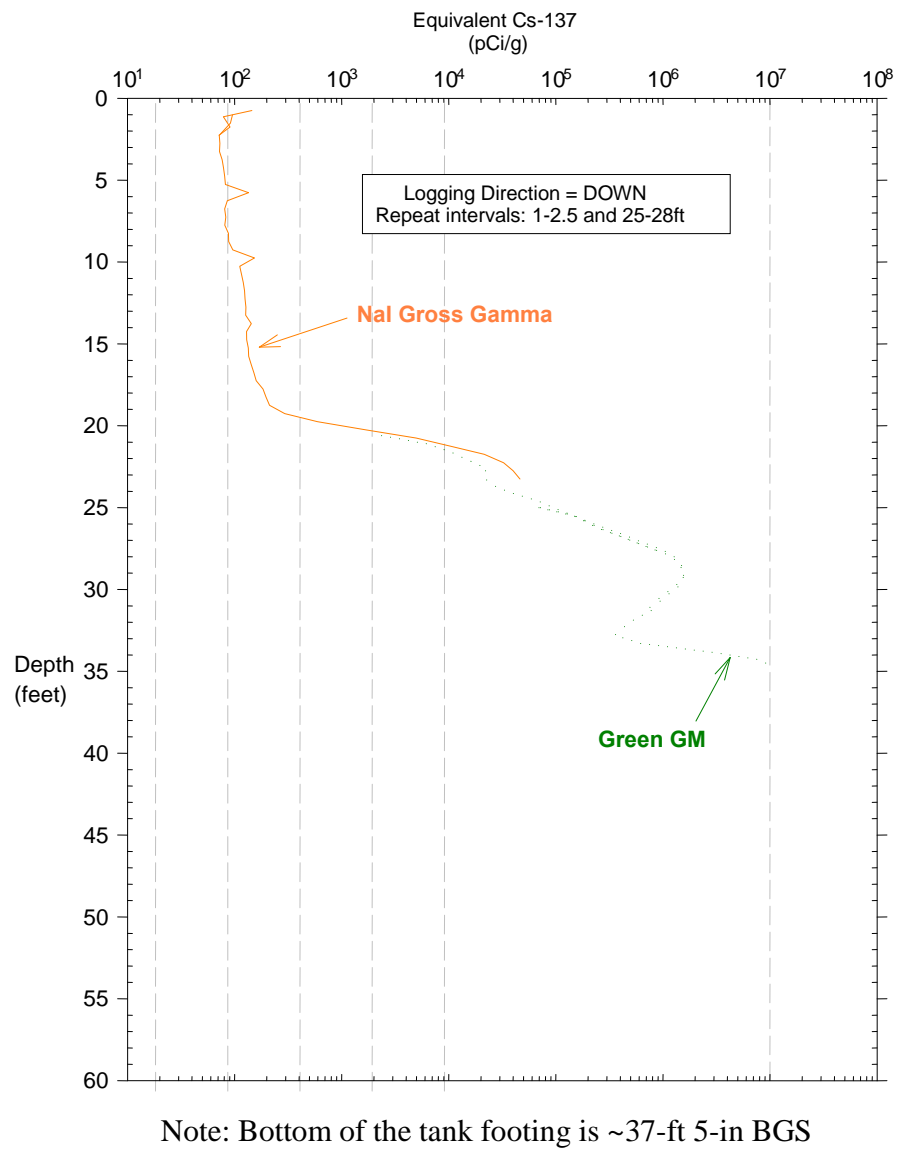

Below the 28-ft BGS peak, the soil contamination continued to decrease with depth before rising again in a second, much more intense contamination peak located at the base of the tank. The peak indicates that either the inlet cascade line penetration leak accumulated at the tank base, or else a second waste source is present at this depth. The direct push was terminated at the tank footing when resistance was met.

During this period, drywell 30-05-07 was re-logged and a comparison of the radiation logs between direct push C7469 and drywell 30-05-07 is shown in Figure 5-24. Drywell 30-05-07 is located roughly twice the distance from the sidewall and cascade line penetration than direct push C7469. The drywell 30-05-07 log shows no evidence of the inlet cascade line penetration 
leak detected by C7469. At the top of the tank C-105 footing, direct push C7469 recorded $1 \mathrm{x}$ $10^{7} \mathrm{pCi} / \mathrm{g}$ while drywell 30-05-07 recorded $\sim 1 \times 10^{4} \mathrm{pCi} / \mathrm{g}$, an attenuation factor of 1000x over a horizontal distance of $3.9-\mathrm{ft}$. Immediately below the tank footing, the soil contamination detected in drywell 30-05-07 continued to increase to a maximum Cs-137 peak of $\sim 4 \times 10^{7}$ $\mathrm{pCi} / \mathrm{g}$. The concentration in this lower peak is 20 to 40 times higher than the upper peak detected at 28-ft BGS in direct push C7469 (RPP-ASMT-46452).

Figure 5-24. Direct Push C7469 and Drywell 30-05-07 Soil Contamination Profiles Comparison (RPP-ASMT-46452, Rev. 0)

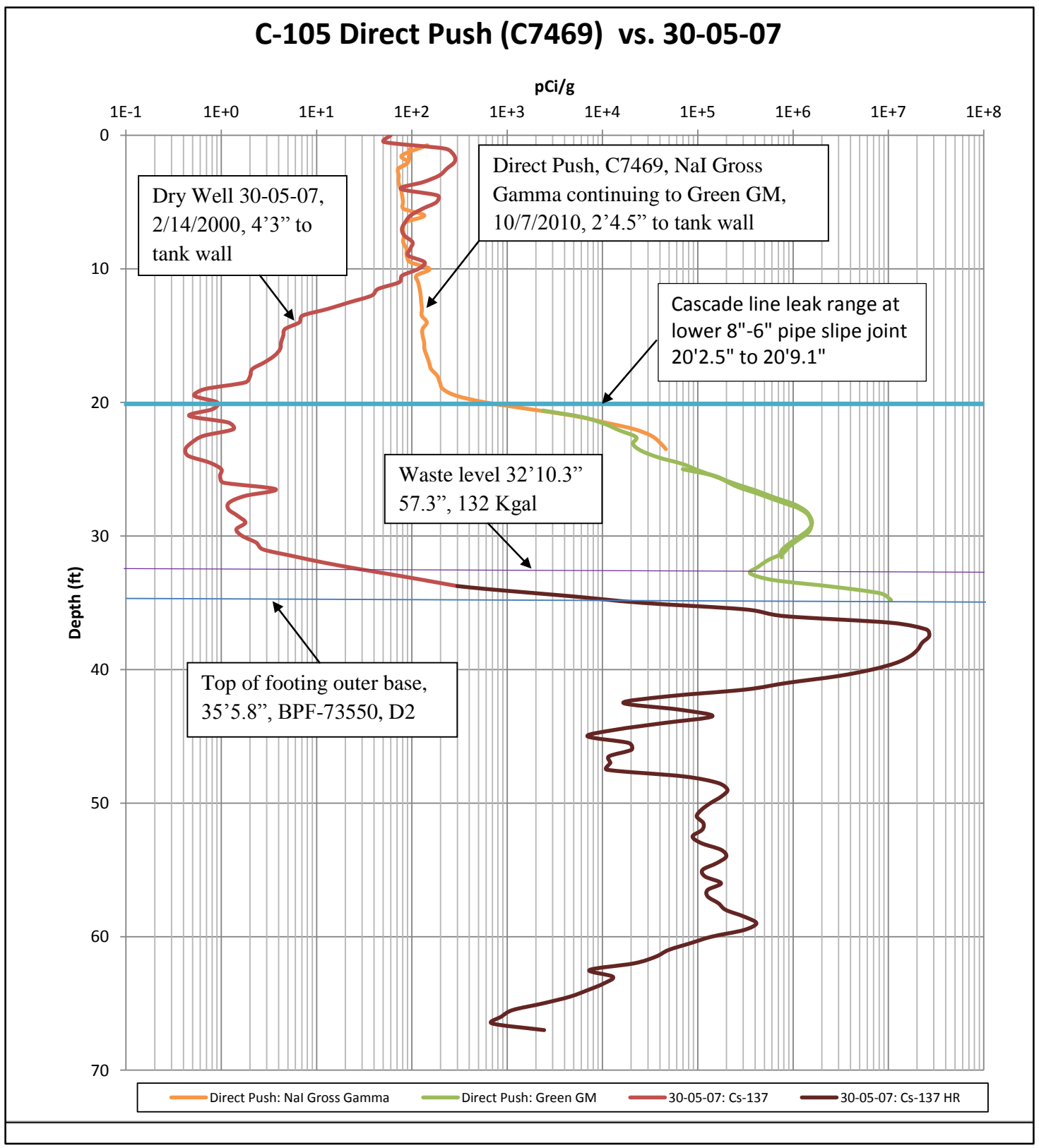




\subsubsection{Drywell Summary}

Tank C-105 drywells 30-05-02, 30-05-04, 30-05-05, 30-04-04, 30-04-05, 30-05-06, 30-04-01, 30-04-12, 30-05-09, and 30-05-10 do not indicate any radioactivity associated with a tank C-105 liner leak. Therefore, these drywells are not included in the leak location for tank C-105.

The tank C-105 drywells were installed in 1972 and 1974 and radioactivity was reported in drywells 30-05-03, 30-05-07, 30-04-03, 30-04-02, and 30-05-08 in the first recoverable readings found. Drywell C4297 and direct push C7469 were installed later (2004 and 2009, respectively) which can help support earlier data.

Drywell 30-05-03 reports low level radioactivity with a peak at $\sim 32-\mathrm{ft}$ BGS. The 1997 SGLS data reports a thick zone of Cs-137 contamination from the ground surface to 38.5-ft BGS. The radioactivity reported in this drywell could be a result of a tank leak and/or a leak from the nearby condenser.

Drywells 30-04-02, 30-04-03, 30-05-08, and drywell C4297 all indicate radioactivity that could be the result of a tank leak and/or a line leak from the C-104-to-C-105 cascade line and/or Line V103. The C-104-to-C-105 cascade line inlet elevation is $\sim 20-\mathrm{ft} B G S$ at tank C-105. The source of radioactivity detected in drywells 30-04-02, 30-04-03, 30-05-08, and drywell C4297 report radioactivity at this higher BGS level which could be associated with a cascade line leak and/or Line V103 leak. However, a tank C-105 leak cannot be ruled out as some of these drywells report an additional peak at the base of the tank (see individual drywell sections).

Drywell 30-05-07 is located $~ 2-f t$ from the tank C-105 footing at roughly the 7:00 position and direct push C7469 is located at the tank footing between drywell 30-05-07 and the cascade inlet line. Drywell 30-05-07 reported a peak at 37-ft BGS and concentrations reported at this depth were nearly $10^{6}$ times higher than any other measurements from other tank C-104 or C-105 drywells. In 2009, direct push C7469 was installed and two distinct peaks were reported, one at 28-ft BGS and the other at the base of the tank (see Figure 5-24). The peak at 28-ft BGS is likely due to a leak from the inlet cascade line penetration. The peak at the tank base indicated that either the inlet cascade line penetration leak accumulated at the tank base, or else a second waste source (i.e., tank C-105 leak) is present at this depth. In 2009, drywell 30-05-07 was re-logged and results show no evidence of the inlet cascade line penetration leak detected by direct push C7469.

\subsection{POSSIBLE TANK C-105 LINER LEAK LOCATION(S)}

A liner leak may have penetrated the waterproof membrane at any location or pooled on the waterproof membrane and followed concrete cracks or construction joints to a different location for egress to the soil, including the top of the tank footing.

Tank C-105 had at least one leak site, likely near the bottom of the tank, based on radioactivity detected in the drywells or could also be attributed to leaking inlet side wall connections. There is also a remote possibility of a small leak near the condenser based on radioactivity detected in drywell 30-05-03, or could also be attributed to a leak from the condenser. 


\subsubsection{Leak Detected Before 1974- Leak Site A}

Tank C-105 was first suspected of leaking based on radioactivity detected in drywell 30-04-02; ten additional drywells were installed as a result. During this time liquid level decreases were reported to be normal due to evaporation. After further analyses, it was determined the tank was not actively leaking and tank C-105 was returned to service in October 1974. Tank C-105 continued to be kept in service with the last transfer out of the tank in June 1979 and water additions to allow for cooling continued until the mid-1990s.

The integrity of the tank was reassessed later and drywell C4297 and direct push C7469 were installed in 2004 and 2009, respectively. Drywells 30-04-02, 30-04-03, 30-05-08 and drywell $\mathrm{C} 4297$ all indicate radioactivity that could be the result of a tank leak and/or a line leak (C-104to-C-105 cascade line and/or Line V103). Drywell 30-05-07 reported a peak at 37-ft BGS and concentrations were much greater than any other nearby drywell likely indicating a tank liner leak as shown in Figure 5-25. Direct push C7469 reported two separate peaks, one consistent with a cascade line leak, and the other peak either a continuation of the cascade line leak or a tank leak near the bottom of the tank.

Figure 5-25. Tank C-105 Possible Leak Location (Before 1974)

Tank inner ring is steel liner; outer ring is outer edge of tank footing

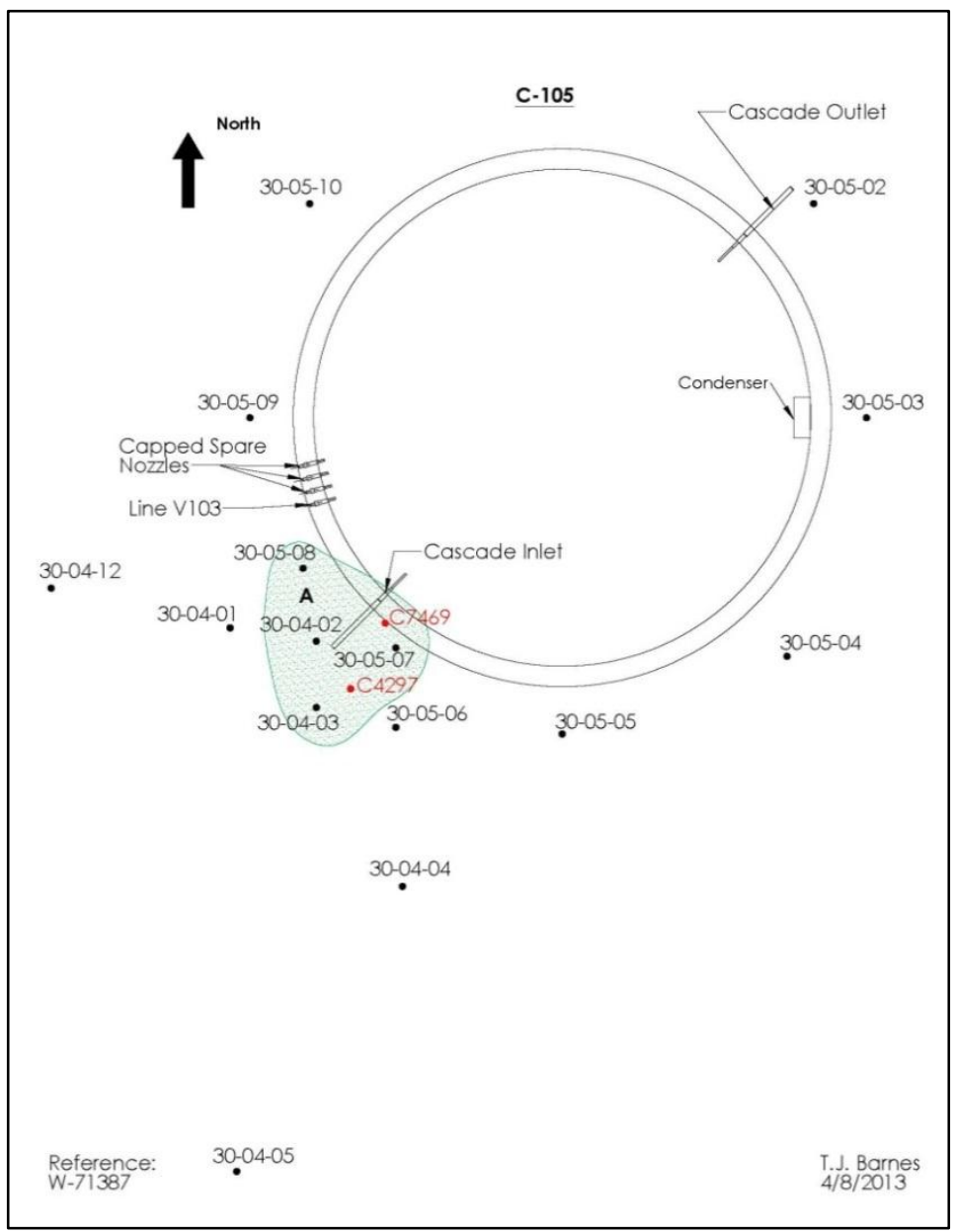




\subsubsection{Leak Detected Before 1974- Leak Site B}

Drywell 30-05-03 reported low level radioactivity with a peak at approximately 32-ft BGS (see site B in Figure 5-26). Later SGLS data reports a thick zone of Cs-137 contamination from the ground surface to 38.5 -ft BGS. This appears to be a separate site unrelated to the radioactivity detected in the southern portion of tank C-105 (see site A in Figure 5-25). The radioactivity reported in this drywell could be due to a tank leak and/or a leak from the nearby condenser.

Figure 5-26. Tank C-105 Possible Leak Location (Before 1974)

Tank inner ring is steel liner; outer ring is outer edge of tank footing

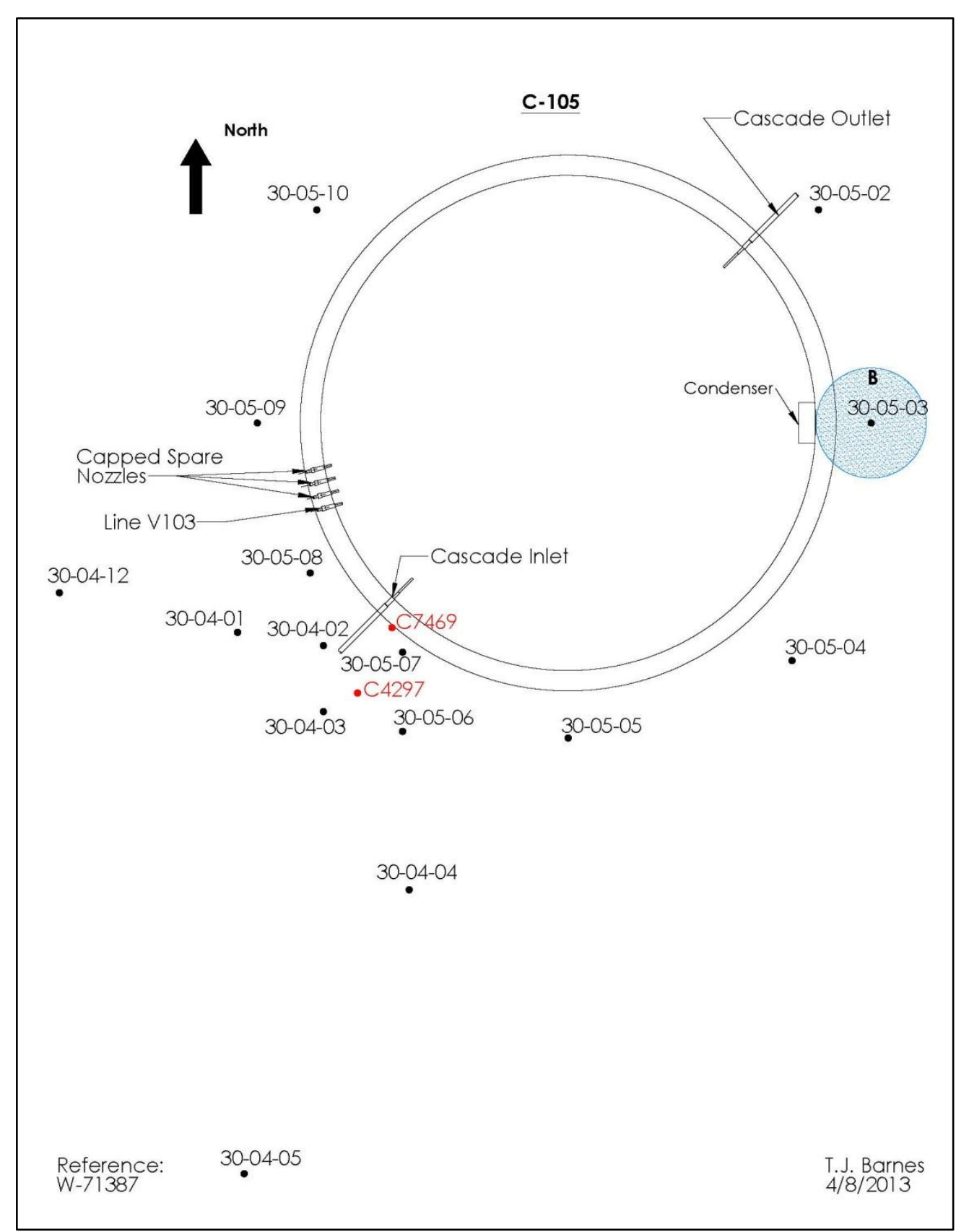




\subsubsection{Leak Location Summary}

Tank C-105 was first suspected of leaking based on radioactivity detected in drywell 30-04-02 in 1974, at which time ten additional drywells were installed. Drywell C4297 and direct push C7469 were installed later in 2004 and 2009, respectively. Drywells 30-04-02, 30-04-03, 30-0508, and drywell $\mathrm{C} 4297$ all indicate radioactivity that could be the result of a tank leak and/or a line leak from the C-104-to-C-105 cascade line and/or Line V103 (see Figure 5-27). Drywell 3005-07 reported a peak at the base of the tank (37-ft BGS) and concentrations reported were much greater than any readings from the other drywells likely indicating a tank leak. Direct push C7469, installed in 2009, reported two separate peaks, one consistent with a cascade line leak, and the other peak either a continuation of the cascade line leak or a tank leak near the bottom of the tank.

Also during the same time frame, drywell 30-05-03 reported low level radioactivity at approximately 32-ft BGS. Later SGLS data reports a thick zone of Cs-137 contamination from the ground surface to 38.5 -ft BGS. Radioactivity reported in this drywell could be due to a tank leak, separate from site A (see Figure 5-27), and/or a leak from the nearby condenser.

Leak locations in Figure 5-27 are based on peak readings and are a representation of possible initial boundaries of radioactivity.

No evidence was found for a liner bulge occurring in tank C-105, and it remains unclear if a liner bulge once existed in the tank during its operation. Tank C-105 temperatures above $180^{\circ} \mathrm{F}$ up to boiling temperature during PSS storage after 15 years of waste storage were not likely to cause a liner bulge as most of the grout moisture or asphaltic vapors that typically cause bulging would have dissipated. 
Figure 5-27. Tank C-105 Possible Radial Leak Locations

Tank inner ring is steel liner, outer ring is outer edge of tank footing

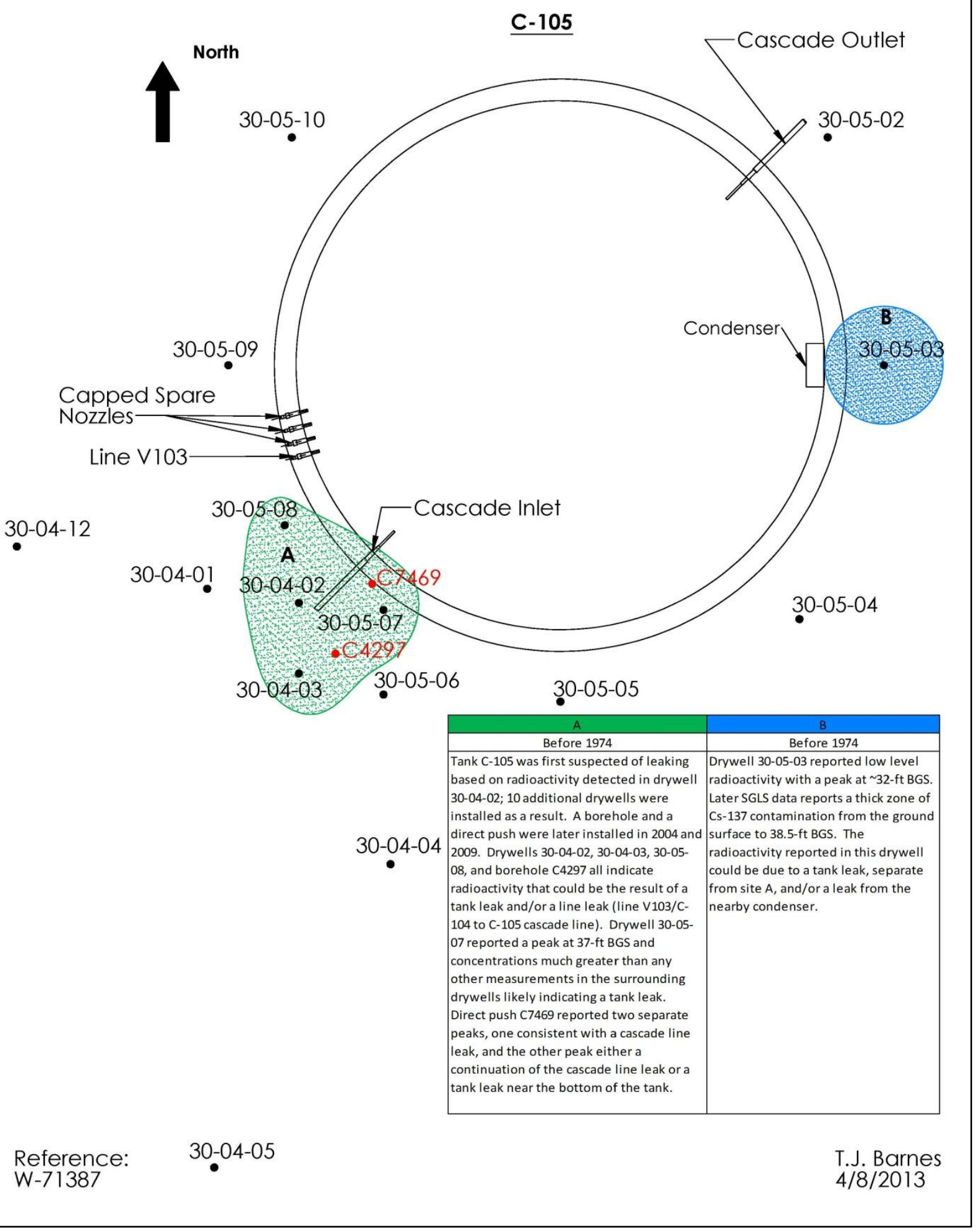


RPP-RPT-54914, Rev. 0

\subsection{POSSIBLE TANK C-105 LINER LEAK CAUSE(S)}

Tank C-105 was examined against five conditions that could contribute to a failed liner.

\subsubsection{Tank Design}

The C Farm tank design does not appear to be a factor contributing to a failed liner (see Section 3.1.1).

\subsubsection{Thermal Conditions}

No temperature data are available for tank C-105 prior to 1974, however, tank C-105 held only non-boiling waste. Since no records are available, it is uncertain what the maximum temperature was in tank C-105 during operation as well as the rate of temperature rise when waste was initially added. Tank C-105 was equipped with an atmospheric condenser which was reported to be adequate for the original operating waste temperatures (approximately $180^{\circ} \mathrm{F}$ for supernatant and sludge) and vapor loads (see Section 5.4.2). However, reports of "steaming" and a Cs-137 supernatant concentration of $\sim 9.7 \mathrm{Ci} / \mathrm{gal}$ in May 1963 would confirm a relatively high temperature in tank $\mathrm{C}-105$, probably exceeding $180^{\circ} \mathrm{F}$ up to possible boiling temperature.

Thermal shock creates stress both from rapid temperature rise as well as waste-induced high temperatures.

Temperature requirements in ARH-951 (Limitations for Use of Underground Waste Tanks) issued December 18, 1969, indicated that tank temperatures should be held below $230^{\circ} \mathrm{F}$.

\subsubsection{Chemistry-Corrosion}

Tank C-105 stored MW, TBP, CWP, IX, PSS, RSN, and PUREX HLW during operation. Tank C-105 stored only waste type TBP for approximately two years.

TBP waste consists of low hydroxide and high nitrate concentrations, likely with low nitrite concentrations, which would create an environment conducive to pitting and SCC. A tank with TBP waste type present would likely increase SCC in the tank liner (see Section 3.2.4 and 5.4.4).

Waste types PSS and RSN could create an environment conducive to SCC; however, this would be to a lesser degree than TBP waste as PSS and RSN may have been diluted some with water addition. Additionally during the RSN and PSS waste transfers into and out of tank C-105 the temperatures were probably decreasing from the higher temperatures during PUREX HLW storage $>180^{\circ} \mathrm{F}$ and later temperatures in 1974 of $125^{\circ} \mathrm{F}$. Other wastes stored in tank C-105 should not have resulted in pitting or SCC.

\subsubsection{Liner Observations}

A review of the available photographs for tank C-105 does not contain any evidence pointing to a tank leak. There is no documentation available indicating a liner bulge was present in tank $\mathrm{C}$ 105. 


\subsubsection{Tank Construction Temperature}

The C Farm tank liners were constructed between August 1944 and December 1944. No climatological data is available during that time. However, the time of the year suggests that it is unlikely there would be temperatures low enough to affect the ductile-to-brittle transition temperature. Impact occurrences could have occurred but it is unlikely they would have resulted in fractures due to encountering the ductile-to-brittle transition temperature.

\subsection{TANK C-105 CONCLUSIONS}

Some evidence indicates that the tank C-105 liner may have leaked at or near the tank footing in either one or two locations based on radioactivity detected in the drywells. However, the proximity of the inlet lines, cascade inlet, and the condenser could also be a cause of the radioactivity.

There are several liner leak cause conditions that were examined but the most likely cause of the tank C-105 leak was chemistry-corrosion as it relates to the storage of TBP process wastes there was also temperature possibly up to boiling associated with PSS storage. The TBP process waste is conducive to pitting and SCC. Waste types PSS and possibly RSN at elevated temperatures could have also created an environment conducive to SCC. Waste chemistry was not controlled to the degree necessary to minimize corrosion when tank C-105 was suspected of leaking. There appears to be very little contribution from tank design and construction temperatures, however thermal conditions may have had some effect on liner integrity. Some or all of the factors can act serially or together to contribute to tank liner failure. 
RPP-RPT-54914, Rev. 0

APPENDIX A2

TANK C-105 GROSS GAMMA DRYWELL DATA 
RPP-RPT-54914, Rev. 0

Table 02-1. Tank C-105 Drywell Radioactivity (K counts per minute) (March 1973 through March 1987) Page 1 of 3 (SD-WM-TI-356)

\begin{tabular}{|c|c|c|c|c|c|c|c|c|c|c|c|c|c|c|c|}
\hline \multicolumn{2}{|c|}{ 30-04-01 } & \multicolumn{3}{|c|}{ 30-04-02 } & \multicolumn{3}{|c|}{ 30-04-03 } & \multicolumn{3}{|c|}{ 30-04-04 } & \multicolumn{3}{|c|}{ 30-04-05 } & \multicolumn{2}{|c|}{ 30-04-12 } \\
\hline Date & $\begin{array}{c}\text { Peak (K } \\
\text { cpm) }\end{array}$ & Date & $\begin{array}{c}\text { Peak (K } \\
\text { cpm) }\end{array}$ & $\begin{array}{c}\text { Depth } \\
\text { (ft) }\end{array}$ & Date & $\begin{array}{c}\text { Peak (K } \\
\text { cpm) }\end{array}$ & $\begin{array}{c}\text { Depth } \\
\text { (ft) }\end{array}$ & Date & $\begin{array}{c}\text { Peak (K } \\
\text { cpm) }\end{array}$ & $\begin{array}{c}\text { Depth } \\
\text { (ft) }\end{array}$ & Date & $\begin{array}{c}\text { Peak (K } \\
\text { cpm) }\end{array}$ & $\begin{array}{c}\text { Depth } \\
\text { (ft) }\end{array}$ & Date & $\begin{array}{c}\text { Peak (K } \\
\text { cpm) }\end{array}$ \\
\hline \multicolumn{2}{|c|}{ N/A ${ }^{1}$} & $2 / 7 / 1973$ & 25.0 & 41 & \multicolumn{3}{|c|}{ N/A ${ }^{1}$} & \multicolumn{3}{|c|}{ N/A ${ }^{1}$} & \multicolumn{3}{|c|}{ N/A ${ }^{1}$} & $3 / 20 / 1973$ & $<6$ \\
\hline \multicolumn{2}{|c|}{ N/A ${ }^{1}$} & \multicolumn{3}{|c|}{ N/A ${ }^{1}$} & \multicolumn{3}{|c|}{$\mathrm{N}^{\prime} \mathrm{A}^{1}$} & \multicolumn{3}{|c|}{ N/A ${ }^{1}$} & \multicolumn{3}{|c|}{ N/A ${ }^{1}$} & $9 / 24 / 1973$ & $<6$ \\
\hline \multicolumn{2}{|c|}{ N/A ${ }^{1}$} & \multicolumn{3}{|c|}{ N/A ${ }^{1}$} & \multicolumn{3}{|c|}{ N/A ${ }^{1}$} & \multicolumn{3}{|c|}{ N/A ${ }^{1}$} & \multicolumn{3}{|c|}{ N/A ${ }^{1}$} & $1 / 24 / 1973$ & $<3$ \\
\hline $8 / 16 / 1974$ & $<6$ & \multicolumn{3}{|c|}{ N/A ${ }^{1}$} & $8 / 16 / 1974$ & 1349.6 & 23 & $6 / 26 / 1974$ & 15.6 & 10 & 9/9/1974 & 28.6 & 13 & $1 / 16 / 1974$ & $<3$ \\
\hline $12 / 26 / 1974$ & $<6$ & $1 / 16 / 1974$ & 22.0 & 39 & $12 / 5 / 1974$ & 2014.4 & 25 & $10 / 11 / 1974$ & 17.64 & 15 & $12 / 20 / 1974$ & 27.3 & 14 & \multicolumn{2}{|c|}{$\mathrm{N} / \mathrm{A}^{1}$} \\
\hline $\mathrm{N} /$ & & $4 / 1 / 1974$ & 45.0 & 39 & & N/A ${ }^{1}$ & & & N/A ${ }^{1}$ & & & $\mathrm{~N} / \mathrm{A}^{1}$ & & N/ & \\
\hline $\mathrm{N} /$ & & $6 / 10 / 1974$ & 52.2 & 41 & & $\mathrm{~N} / \mathrm{A}^{1}$ & & & N/A ${ }^{1}$ & & & N/A ${ }^{1}$ & & $\mathrm{~N} /$ & \\
\hline $\mathrm{N} / \mathrm{s}$ & & $10 / 11 / 1974$ & 40.4 & 44 & & N/A ${ }^{1}$ & & & N/A ${ }^{1}$ & & & N/A ${ }^{1}$ & & N/ & \\
\hline $\mathrm{N} /$ & & $12 / 23 / 1974$ & 26.3 & 45 & & N/A ${ }^{1}$ & & & $\mathrm{~N} / \mathrm{A}^{1}$ & & & N/A ${ }^{1}$ & & $\mathrm{~N} /$ & \\
\hline $6 / 27 / 1975$ & $<3$ & $6 / 27 / 1975$ & 17.3 & 39 & $2 / 20 / 1975$ & 2291.2 & 22 & $1 / 24 / 1975$ & 13.2 & 14 & $1 / 24 / 1075$ & 28.8 & 13 & $2 / 20 / 1975$ & $<3$ \\
\hline $\mathrm{N} /$ & & $9 / 19 / 1975$ & 18.9 & 40 & $5 / 2 / 1975$ & 2204.6 & 23 & $1 / 24 / 1975$ & 5.94 & 21 & $1 / 24 / 19 / 5$ & 3.0 & 22 & $5 / 8 / 1975$ & $<3$ \\
\hline $\mathrm{N} /$ & & & N/A ${ }^{1}$ & & $5 / 2 / 1975$ & $151.7^{2}$ & 23 & & N/A ${ }^{1}$ & & & N/A ${ }^{1}$ & & $\mathrm{~N} /$ & \\
\hline $2 / 27 / 1976$ & $<3$ & $2 / 27 / 1976$ & 25.8 & 37 & $2 / 27 / 1976$ & $104.8^{2}$ & 21 & $2 / 27 / 1976$ & 2.76 & 21 & $2 / 27 / 1976$ & $<3$ & N/A ${ }^{1}$ & $2 / 27 / 1976$ & $<3$ \\
\hline $4 / 1 / 1977$ & $<3$ & $4 / 1 / 1977$ & 27.8 & 38 & $4 / 1 / 1977$ & $97.3^{2}$ & 22 & $3 / 18 / 1977$ & 2.88 & 21 & $4 / 1 / 1977$ & $<3$ & N/A ${ }^{1}$ & $4 / 1 / 1977$ & $<3$ \\
\hline $4 / 7 / 1978$ & $<3$ & $4 / 7 / 1978$ & 20.2 & 37 & $4 / 7 / 1978$ & $98.2^{2}$ & 21 & $3 / 23 / 1978$ & 3.3 & 21 & $4 / 7 / 1978$ & $<3$ & N/A ${ }^{1}$ & $4 / 7 / 1978$ & $<3$ \\
\hline $4 / 11 / 1979$ & $<3$ & $4 / 11 / 1979$ & 19.6 & 37 & $4 / 11 / 1979$ & $114.1^{2}$ & 21 & $3 / 28 / 1979$ & 2.58 & 21 & $4 / 11 / 1979$ & $<3$ & N/A ${ }^{1}$ & $4 / 11 / 1979$ & $<3$ \\
\hline $4 / 8 / 1980$ & $<3$ & $4 / 9 / 1980$ & 11.2 & 37 & $4 / 8 / 1980$ & $87.2^{2}$ & 21 & $4 / 8 / 1980$ & 2.94 & 21 & $4 / 8 / 1980$ & $<3$ & N/A ${ }^{1}$ & $4 / 8 / 1980$ & $<3$ \\
\hline $\mathrm{N} /$ & & & N/A ${ }^{1}$ & & $8 / 28 / 1980$ & $94.1^{2}$ & 22 & & N/A ${ }^{1}$ & & & N/A ${ }^{1}$ & & $\mathrm{~N} /$ & \\
\hline $\mathrm{N} /$ & & & N/A ${ }^{1}$ & & $9 / 12 / 1980$ & 1154.9 & 21 & & N/A ${ }^{1}$ & & & N/A ${ }^{1}$ & & $\mathrm{~N} /$ & \\
\hline $4 / 9 / 1981$ & $<3$ & $4 / 9 / 1981$ & 7.0 & 37 & $4 / 9 / 1981$ & 1082.4 & 21 & $4 / 8 / 1981$ & 2.4 & 21 & $4 / 8 / 1981$ & $<3$ & N/A ${ }^{1}$ & $4 / 9 / 1981$ & $<3$ \\
\hline $4 / 27 / 1982$ & $<3$ & $4 / 2 / 1982$ & 8.1 & 37 & $4 / 27 / 1982$ & 1380.3 & 23 & $4 / 22 / 1982$ & 2.34 & 21 & $4 / 22 / 1982$ & $<3$ & $\mathrm{~N}^{\prime} \mathrm{A}^{1}$ & $4 / 22 / 1982$ & $<3$ \\
\hline $3 / 30 / 1983$ & $<3$ & $3 / 11 / 1983$ & 7.7 & 39 & $3 / 30 / 1983$ & 931.9 & 23 & $3 / 24 / 1983$ & 4.02 & 21 & $3 / 24 / 1983$ & $<3$ & N/A ${ }^{1}$ & $3 / 24 / 1983$ & $<3$ \\
\hline $\mathrm{N} /$ & & $6 / 23 / 1983$ & 5.6 & 39 & & N/A ${ }^{1}$ & & & N/A ${ }^{1}$ & & & N/A ${ }^{1}$ & & $\mathrm{~N} /$ & \\
\hline $3 / 27 / 1984$ & $<3$ & $6 / 13 / 1984$ & 5.0 & 39 & $3 / 27 / 1984$ & 1353.5 & 23 & $4 / 4 / 1984$ & 3.84 & 21 & $4 / 4 / 1984$ & $<3$ & N/A ${ }^{1}$ & $4 / 4 / 1984$ & $<3$ \\
\hline $4 / 3 / 1985$ & $<3$ & $4 / 18 / 1985$ & 4.4 & 40 & $4 / 3 / 1985$ & 1378.9 & 24 & $4 / 3 / 1985$ & 3.84 & 21 & $4 / 3 / 1985$ & $<3$ & N/A ${ }^{1}$ & $4 / 3 / 1985$ & $<3$ \\
\hline $3 / 6 / 1986$ & $<3$ & $6 / 11 / 1986$ & 4.4 & 40 & $3 / 6 / 1986$ & 1601.3 & 23 & $3 / 6 / 1986$ & 2.94 & 22 & $3 / 7 / 1986$ & $<3$ & N/A ${ }^{1}$ & $3 / 6 / 1986$ & $<3$ \\
\hline $2 / 4 / 1987$ & $<3$ & $6 / 19 / 1987$ & 4.6 & 41 & $2 / 4 / 1987$ & 1648.0 & 24 & $2 / 4 / 1987$ & 3.6 & 21 & $2 / 4 / 1987$ & $<3$ & N/A ${ }^{1}$ & $2 / 4 / 1987$ & $<3$ \\
\hline
\end{tabular}


RPP-RPT-54914, Rev. 0

Table A2-1. Tank C-105 Drywell Radioactivity (K counts per minute) (February 1973 through March 1987) Page 2 of 3 (SD-WM-TI-356)

\begin{tabular}{|c|c|c|c|c|c|c|c|c|c|c|c|c|c|}
\hline \multicolumn{3}{|c|}{$30-05-02$} & \multicolumn{3}{|c|}{$30-05-03$} & \multicolumn{2}{|c|}{$30-05-04$} & \multicolumn{3}{|c|}{$30-05-05$} & \multicolumn{3}{|c|}{$30-05-06$} \\
\hline Date & Peak & Depth & Date & Peak & Depth & Date & Peak & Date & Peak (K & Depth & Date & Peak (K & Depth \\
\hline $3 / 20 / 1973$ & 15.2 & 22 & \multicolumn{3}{|c|}{$\mathrm{N} / \mathrm{A}^{1}$} & $2 / 7 / 1973$ & $<6$ & \multicolumn{3}{|c|}{$\mathrm{N} / \mathrm{A}^{1}$} & \multicolumn{3}{|c|}{$\mathrm{N} / \mathrm{A}^{1}$} \\
\hline $4 / 26 / 1974$ & 11.4 & 21 & $10 / 25 / 1974$ & 16.8 & 32 & $4 / 15 / 1974$ & $<6$ & $7 / 3 / 1974$ & 20.9 & 64 & $8 / 16 / 1974$ & 7.2 & 43 \\
\hline $1 / 31 / 1975$ & 9.7 & 21 & $1 / 24 / 1975$ & 15.9 & 31 & $1 / 24 / 1975$ & $<6$ & $1 / 1 / 1975$ & 18.8 & 63 & $1 / 1 / 1975$ & 6.4 & 46 \\
\hline $7 / 18 / 1975$ & 0.7 & 21 & $7 / 18 / 1975$ & 12.8 & 30 & $7 / 18 / 1975$ & $<3$ & $4 / 25 / 1975$ & 18.0 & 62 & $4 / 25 / 1975$ & 5.5 & 46 \\
\hline \multicolumn{3}{|c|}{ N/A ${ }^{1}$} & \multicolumn{3}{|c|}{ N/A ${ }^{1}$} & \multicolumn{2}{|l|}{$\mathrm{N} / \mathrm{A}^{1}$} & $7 / 18 / 1975$ & 18.6 & 63 & $7 / 18 / 1975$ & 4.6 & 47 \\
\hline $2 / 27 / 1976$ & 5.5 & 72 & $2 / 27 / 1976$ & 18.4 & 30 & $2 / 27 / 1976$ & $<3$ & $2 / 27 / 1976$ & 18.5 & 61 & $2 / 27 / 1976$ & 3.7 & 44 \\
\hline $4 / 1 / 1977$ & 4.7 & 73 & $4 / 1 / 1977$ & 15.1 & 29 & $4 / 1 / 1977$ & $<3$ & $4 / 1 / 1977$ & 19.9 & 61 & $4 / 1 / 1977$ & 2.5 & 47 \\
\hline $4 / 7 / 1978$ & 4.0 & 73 & $4 / 7 / 1978$ & 13.7 & 29 & $4 / 7 / 1978$ & $<3$ & $4 / 7 / 1978$ & 18.8 & 60 & $4 / 7 / 1978$ & 2.5 & 47 \\
\hline $4 / 11 / 1979$ & 3.8 & 72 & $4 / 11 / 1979$ & 16.3 & 30 & $4 / 11 / 1979$ & $<3$ & $4 / 11 / 1979$ & 15.8 & 61 & $4 / 11 / 1979$ & 2.3 & 45 \\
\hline $4 / 15 / 1980$ & 3.2 & 73 & $4 / 15 / 1980$ & 15.2 & 29 & $4 / 15 / 1980$ & $<3$ & $4 / 8 / 1980$ & 15.9 & 61 & $4 / 9 / 1980$ & $<3$ & N/A ${ }^{1}$ \\
\hline $4 / 16 / 1981$ & 2.9 & 76 & $4 / 16 / 1981$ & 13.3 & 28 & $4 / 16 / 1981$ & $<3$ & $4 / 9 / 1981$ & 14.8 & 61 & $4 / 9 / 1981$ & $<3$ & N/A ${ }^{1}$ \\
\hline $4 / 22 / 1982$ & 2.6 & 72 & $4 / 22 / 1982$ & 11.0 & 29 & $4 / 27 / 1982$ & $<3$ & $4 / 27 / 1982$ & 14.9 & 60 & $4 / 22 / 1982$ & $<3$ & N/A ${ }^{1}$ \\
\hline $4 / 4 / 1983$ & 6.4 & 21 & $4 / 4 / 1983$ & 9.8 & 31 & $4 / 4 / 1983$ & $<3$ & $4 / 4 / 1983$ & 16.0 & 63 & $4 / 4 / 1983$ & $<3$ & N/A ${ }^{1}$ \\
\hline $4 / 5 / 1984$ & 7.7 & 21 & $4 / 5 / 1984$ & 13.2 & 32 & $4 / 5 / 1984$ & $<3$ & $4 / 5 / 1984$ & 16.6 & 63 & $4 / 5 / 1984$ & $<3$ & $\mathrm{~N} / \mathrm{A}^{1}$ \\
\hline $3 / 27 / 1985$ & 5.3 & 22 & $3 / 27 / 1985$ & 12.6 & 33 & $3 / 27 / 1985$ & $<3$ & $3 / 27 / 1986$ & 13.9 & 64 & $3 / 27 / 1985$ & $<3$ & N/A ${ }^{1}$ \\
\hline $3 / 18 / 1986$ & 6.1 & 22 & $3 / 18 / 1986$ & 12.1 & 33 & $4 / 9 / 1986$ & $<3$ & $4 / 9 / 1986$ & 15.2 & 64 & 4/10/1986 & $<3$ & N/A ${ }^{1}$ \\
\hline $3 / 31 / 1987$ & 5.9 & 22 & $3 / 31 / 1987$ & 12.0 & 33 & $3 / 31 / 1987$ & $<3$ & $3 / 31 / 1987$ & 14.2 & 65 & $3 / 31 / 1987$ & $<3$ & N/A ${ }^{1}$ \\
\hline
\end{tabular}

Note: ${ }^{1}$ N/A: Data not available 
RPP-RPT-54914, Rev. 0

Table A2-1. Tank C-105 Drywell Radioactivity (K counts per minute) (February 1973 through March 1987) Page 3 of 3 (SD-WM-TI-356)

\begin{tabular}{|c|c|c|c|c|c|c|c|c|c|c|}
\hline \multicolumn{3}{|c|}{ 30-05-07 } & \multicolumn{3}{|c|}{$30-05-08$} & \multicolumn{2}{|c|}{$30-05-09$} & \multicolumn{3}{|c|}{$30-05-10$} \\
\hline Date & $\begin{array}{c}\text { Peak (K } \\
\text { cpm) }\end{array}$ & $\begin{array}{c}\text { Depth } \\
\text { (ft) }\end{array}$ & Date & $\begin{array}{c}\text { Peak (K } \\
\text { cpm) }\end{array}$ & $\begin{array}{c}\text { Depth } \\
\text { (ft) }\end{array}$ & Date & $\begin{array}{c}\text { Peak (K } \\
\text { cpm) }\end{array}$ & Date & $\begin{array}{c}\text { Peak (K } \\
\text { cpm) }\end{array}$ & $\begin{array}{c}\text { Depth } \\
\text { (ft) }\end{array}$ \\
\hline \multicolumn{3}{|c|}{ N/A ${ }^{1}$} & \multicolumn{3}{|c|}{$\mathrm{N} / \mathrm{A}^{1}$} & \multicolumn{2}{|c|}{ N/A ${ }^{1}$} & $2 / 7 / 1973$ & 12.0 & N/A ${ }^{1}$ \\
\hline $8 / 15 / 1974$ & 837.4 & 37 & $8 / 16 / 1974$ & 235.6 & 16 & $6 / 26 / 1974$ & $<3$ & $4 / 26 / 1974$ & 5.5 & 20 \\
\hline \multicolumn{3}{|c|}{ N/A ${ }^{1}$} & \multicolumn{3}{|c|}{ N/A ${ }^{1}$} & \multicolumn{2}{|c|}{ N/A ${ }^{1}$} & $5 / 29 / 1974$ & 6.1 & 23 \\
\hline $1 / 29 / 1975$ & 976.0 & 37 & $1 / 10 / 1975$ & 290.3 & 18 & $1 / 10 / 1975$ & $<3$ & $1 / 24 / 1975$ & 4.8 & 23 \\
\hline $7 / 18 / 1975$ & 921.0 & 36 & $1 / 24 / 1975$ & 85.9 & 39 & $1 / 24 / 1975$ & $<3$ & \multicolumn{3}{|c|}{$\mathrm{N} / \mathrm{A}^{1}$} \\
\hline \multicolumn{3}{|c|}{ N/A ${ }^{1}$} & $7 / 18 / 1975$ & 79.6 & 39 & $7 / 18 / 1975$ & $<3$ & $7 / 19 / 1975$ & 5.7 & 22 \\
\hline $3 / 2 / 1976$ & 879.4 & 35 & $2 / 27 / 1976$ & 61.7 & 35 & $3 / 5 / 1976$ & $<3$ & $2 / 27 / 1976$ & 4.4 & 22 \\
\hline $3 / 29 / 1977$ & 959.1 & 36 & 4/1/1977 & 25.4 & 35 & 4/1/1977 & $<3$ & 4/1/1977 & 3.7 & 23 \\
\hline 4/4/1978 & 725.8 & 35 & 4/7/1978 & 20.3 & 36 & 4/7/1978 & $<3$ & \multicolumn{3}{|c|}{$\mathrm{N} / \mathrm{A}^{1}$} \\
\hline 4/9/1979 & 713.0 & 35 & $4 / 11 / 1979$ & 11.3 & 37 & $4 / 12 / 1979$ & $<3$ & \multicolumn{3}{|c|}{ N/A ${ }^{1}$} \\
\hline $1 / 28 / 1980$ & 937.4 & 35 & $4 / 9 / 1980$ & 10.0 & 36 & $4 / 9 / 1980$ & $<3$ & $4 / 9 / 1980$ & 2.6 & 21 \\
\hline $3 / 10 / 1980$ & 704.2 & 37 & \multicolumn{3}{|c|}{$\mathrm{N} / \mathrm{A}^{1}$} & \multicolumn{2}{|c|}{$\mathrm{N} / \mathrm{A}^{1}$} & \multicolumn{3}{|c|}{$\mathrm{N} / \mathrm{A}^{1}$} \\
\hline $4 / 21 / 1980$ & 974.2 & 34 & \multicolumn{3}{|c|}{ N/A ${ }^{1}$} & \multicolumn{2}{|c|}{ N/A ${ }^{1}$} & \multicolumn{3}{|c|}{$\mathrm{N} / \mathrm{A}^{1}$} \\
\hline $6 / 2 / 1980$ & 878.9 & 35 & \multicolumn{3}{|c|}{$\mathrm{N}^{\prime} \mathrm{A}^{1}$} & \multicolumn{2}{|c|}{ N/A ${ }^{1}$} & \multicolumn{3}{|c|}{$\mathrm{N}^{\prime} \mathrm{A}^{1}$} \\
\hline $6 / 16 / 1980$ & $332.8^{2}$ & 35 & \multicolumn{3}{|c|}{ N/A ${ }^{1}$} & \multicolumn{2}{|c|}{ N/A ${ }^{1}$} & \multicolumn{3}{|c|}{ N/A ${ }^{1}$} \\
\hline $4 / 6 / 1981$ & 330.1 & 35 & 4/9/1981 & 8.6 & 36 & $4 / 9 / 1981$ & $<3$ & $4 / 9 / 1981$ & $<3$ & N/A ${ }^{1}$ \\
\hline $4 / 26 / 1982$ & 318.2 & 37 & $4 / 27 / 1982$ & 7.9 & 35 & $4 / 27 / 1982$ & $<3$ & $4 / 27 / 1982$ & $<3$ & N/A ${ }^{1}$ \\
\hline $4 / 4 / 1983$ & 355.6 & 37 & $4 / 4 / 1983$ & 5.2 & 37 & $4 / 4 / 1983$ & $<3$ & $4 / 4 / 1983$ & $<3$ & $\mathrm{~N} / \mathrm{A}^{1}$ \\
\hline $4 / 5 / 1984$ & 333.4 & 37 & $4 / 5 / 1984$ & 4.4 & 38 & $4 / 5 / 1984$ & $<3$ & $4 / 5 / 1984$ & $<3$ & N/A ${ }^{1}$ \\
\hline $3 / 27 / 1985$ & 331.8 & 38 & $3 / 27 / 1985$ & 3.3 & 39 & $3 / 27 / 1985$ & $<3$ & $3 / 27 / 1985$ & $<3$ & N/A ${ }^{1}$ \\
\hline $3 / 17 / 1986$ & 351.2 & 38 & 4/10/1986 & 3.8 & 38 & 4/10/1986 & $<3$ & 4/10/1986 & $<3$ & $\mathrm{~N}^{\prime} \mathrm{A}^{1}$ \\
\hline 4/1/1987 & 337.0 & 38 & $3 / 31 / 1987$ & 3.9 & 39 & $3 / 31 / 1987$ & $<3$ & $3 / 31 / 1987$ & $<3$ & N/A ${ }^{1}$ \\
\hline
\end{tabular}


RPP-RPT-54914, Rev. 0

\subsection{CONCLUSIONS}

Some evidence indicates that the tank C-101 liner may have leaked near the west portion of the tank possibly in the tank sidewall based on the radioactivity in drywell 30-01-09, however, the proximity of the inlet lines could also be a source of drywell 30-01-09 radioactivity. The liquid level analysis points to an inlet line packing leak.

Some evidence indicates that the tank C-105 liner may have leaked at or near the tank footing in either one or two locations based on radioactivity detected in the drywells. However, the proximity of the inlet lines and cascade inlet to one location, and the condenser to the second location could also be a cause of the radioactivity.

There are several liner leak cause conditions that were examined for tanks C-101 and C-105 which include tank design, construction conditions, thermal conditions, and chemistry-corrosion. Chemistry-corrosion, relating to the storage of TBP and possible PSS and RSN process wastes, appears to be the most likely cause of the leak(s) for tanks C-101 and C-105 as there seems to be very little contribution from tank design, construction temperatures, and thermal conditions. Waste types TBP, PSS and possibly RSN at elevated temperatures could have created an environment conducive to SCC.

Ten of the C Farm tanks are sound which includes two, tanks C-110 and C-111, which were recommended to be categorized as sound after a TFC-ENG-CHEM-D-42 assessment. The assessments resulted in low probabilities of a tank liner leak from the expert panel elicitations for both of these tanks (RPP-ASMT-38219, Rev 0, Tank 241-C-110 Leak Assessment Report and RPP-ASMT-39155, Rev. 0, Tank 241-C-111 Leak Assessment Report). The tank C-105 TFCENG-CHEM-D-42 assessment expert elicitations, however, resulted in a wide range of probabilities and the first formal leak assessment where the average expert elicitation probability of 0.42 was 0.10 above the previous six formal leak assessments (RPP-ASMT-46452, Tank 241C-105 Leak Assessment Completion Report). A probability of $<0.5$ favors the non-leak hypothesis - a waste overflow through the inlet cascade line penetration. However, there was consensus among the members of the leak assessment panel that a leak from tank C-105 could not be ruled out by the evidence from the direct push C7469 and other available data. The leak through the inlet cascade line penetration may have contributed to the radioactivity peak at the base of the tank, but the extent is uncertain, and a tank leak is also plausible.

An informal assessment of tank C-101 concluded, based on liquid level measurements, evaporation calculations, and low gamma activity in drywells, that the tank probably did not leak, and if it did leak the release point would have been high on the tank wall (RPP-ENV33418 , Rev, 2). A recommendation was made that sluicing could proceed below 54-in measured from the bottom center of the tank. The tank C-101 sluicing program, to date, has not resulted in any measured liner leakage from sluicing.

A comparison of the C Farm tanks classified as leaking (see Table 6-1) to those C Farm tanks classified as sound (see Table 6-2) indicates the corrosivity of the TBP waste may be mitigated by other unknown factors as all the $\mathrm{C}$ Farm tanks stored TBP waste at some point during 
operation. Adding in the potential SCC effects of RSN and PSS to tank C-105 would not be an overriding factor.

The discussions in the above paragraphs indicate there are remaining uncertainties whether either tank C-101 or tank C-105 liners leaked. Both tanks were overfilled and evidence indicates that leakage from the capped spare inlet nozzles, and/or cascade line, and additionally in the case of tank C-105 the condenser and/or Line V103, may be the only leakage from the tanks. There is insufficient and conflicting information available from drywells to improve judgments on the source of the radioactivity detected in the soil around tanks C-101 and C-105. 
RPP-RPT-54914, Rev. 0

Table 6-1. C Farm Leaking Tanks

\begin{tabular}{|c|c|c|c|c|c|c|c|}
\hline \multirow{2}{*}{$\begin{array}{l}\text { Leaking } \\
\text { Tank }\end{array}$} & \multicolumn{2}{|c|}{ Waste Details } & \multicolumn{2}{|c|}{ Leak Status } & \multicolumn{2}{|c|}{ TBP Waste Storage } & \multirow{2}{*}{$\begin{array}{c}\text { Thermal Conditions } \\
\text { Estimated Max Temp }\end{array}$} \\
\hline & First Filled & Waste Type & Leak Detected $^{1}$ & Indication of leak & $\begin{array}{l}\text { Stored TBP } \\
\text { Waste }\end{array}$ & $\begin{array}{l}\text { TBP Only Storage } \\
\text { Length }\end{array}$ & \\
\hline C-101 & March 1946 & $\begin{array}{c}\text { MW, TBP, EB, } \\
\text { FeCN, CWP, PUREX } \\
\text { HLW }\end{array}$ & June 1965 & LL decrease & Yes & $\sim 9$ & $110-180^{\circ} \mathrm{F}$ \\
\hline $\mathrm{C}-105^{3}$ & February 1947 & $\begin{array}{c}\text { MW, TBP, } \\
\text { CWP,PUREX HLW, } \\
\text { PSS, RSN, } \mathrm{H}_{2} \mathrm{O}\end{array}$ & Before 1974 & Drywell & Yes & $\sim 2$ years $^{2}$ & $>180^{\circ} \mathrm{F}^{4}$ \\
\hline
\end{tabular}

Notes: $\quad$ Waste Type: MW: Metal Waste; TBP: Tri-butyl phosphate waste; EB: Evaporator bottoms; FeCN: Ferrocyanide waste (CR-Vault); CWP: PUREX cladding waste; PSS: PUREX sludge supernatant; PUREX HLW, PUREX High-Level Waste; RSN: REDOX neutralized supernate, $\mathrm{H}_{2} \mathrm{O}$ : Water.

1. Leakage may be from other than a liner leak.

2. RSN 3 months October through December 1970 and PSS 18 months January 1971 to July 1972

3. TFC-ENG-CHEM-D-42 assessment recommended "Sound" tank classification be changed to "Assumed Leaker", RPP-ASMT-46452, Rev. 0, Tank 241-C-105 Leak Assessment Completion Report

4. May have reached boiling temperature 
RPP-RPT-54914, Rev. 0

Table 6-2. C Farm Sound Tanks

\begin{tabular}{|c|c|c|c|c|c|c|c|}
\hline \multirow{2}{*}{$\begin{array}{l}\text { Sound } \\
\text { Tank }\end{array}$} & \multicolumn{2}{|c|}{ Waste Details } & \multicolumn{2}{|c|}{ Leak Status } & \multicolumn{2}{|c|}{ TBP Waste Storage } & \multirow{2}{*}{$\begin{array}{c}\text { Thermal Conditions } \\
\text { Estimated Max Temp } \\
\text { (2) }\end{array}$} \\
\hline & First Filled $^{(1)}$ & Waste Type & Leak Integrity Classification $^{1}$ & $\begin{array}{l}\text { Basis for Formal } \\
\text { Leak Assessment }\end{array}$ & $\begin{array}{l}\text { Stored TBP } \\
\text { Waste }\end{array}$ & $\begin{array}{l}\text { TBP Only Storage } \\
\text { Length }\end{array}$ & \\
\hline C-102 & May 1946 & MW, TBP, OWW, CWP & Sound & - & Yes & $\sim 5$ years & $106^{\circ} \mathrm{F}$ \\
\hline C-103 & August 1946 & $\begin{array}{l}\text { MW, TBP PUREX HLW, } \\
\text { SRS }\end{array}$ & Sound & - & Yes & $\sim 3$ years & $168^{\circ} \mathrm{F}$ \\
\hline C-104 & October 1946 & $\begin{array}{l}\text { MW, TBP; CWP, OWW, } \\
\text { BL }\end{array}$ & Sound & - & Yes & $\sim 4$ months & $129^{\circ} \mathrm{F}$ \\
\hline C-106 & June 1947 & $\begin{array}{l}\text { MW,TBP, PUREX HLW, } \\
\text { SRS }\end{array}$ & Sound & - & Yes & $\sim 2$ years & $198^{\circ} \mathrm{F}$ \\
\hline C-107 & March 1947 & $\begin{array}{c}\text { MW,TBP, CWP, 1C, IX, } \\
\text { SRS }\end{array}$ & Sound & - & Yes & $\sim 4$ years & $170^{\circ} \mathrm{F}$ \\
\hline C-108 & September 1947 & MW, TBP, $1 \mathrm{C}$ & Sound & - & Yes & $\sim 6$ years & $96^{\circ} \mathrm{F}$ \\
\hline C-109 & March 1948 & MW, TBP 1C, CWP, IX & Sound & - & Yes & $\sim 4$ years & $160^{\circ} \mathrm{F}$ \\
\hline C-110 & June 1946 & TBP, 1C, OWW, EB, IX & $\begin{array}{c}\text { Sound } \\
\text { per TFC-ENG-CHEM-D-42 }\end{array}$ & - & Yes & $\sim 3$ years & $110^{\circ} \mathrm{F}$ \\
\hline C-111 & August 1946 & $\begin{array}{c}\mathrm{CW}, \mathrm{TBP}, 1 \mathrm{C}, \mathrm{OWW}, \mathrm{EB}, \\
\mathrm{IX}\end{array}$ & $\begin{array}{c}\text { Sound } \\
\text { Per TFC-ENG-CHEM-D- } 42^{4} \\
\end{array}$ & - & Yes & $\sim 3$ years & $190^{\circ} \mathrm{F}$ \\
\hline C-112 & October 1946 & CWP, TBP, 1C, IX & Sound & - & Yes & $\sim 3$ years & $160^{\circ} \mathrm{F}$ \\
\hline
\end{tabular}

Evaporator bottoms; OWW: PUREX Organic Wash Waste; SRS: Strontium Supernatant; BL: B Plant Low-Level Waste; 1C: $1^{\text {st }}$ Cycle Waste; IX: Ion Exchange;

1 Reference: RPP-ENV-33418, Hanford C-Farm Leak Assessments Report: 241-C-101, 241-C-110, 241-C-111, 241-C-105, and Unplanned Waste Releases.

2 Reference: WHC-SD-WM-TI-591, Rev. 0, Maximum Surface Level and Temperature Histories for Hanford Waste Tanks

3 Reference: RPP-ASMT-38219, Rev 0, Tank 241-C-110 Leak Assessment Report

4 Reference: RPP-ASMT-39155, Rev. 0, Tank 241-C-111 Leak Assessment Report 
RPP-RPT-54914, Rev. 0

\subsection{REFERENCES}

ARH-95, 1967, Chemical Processing Division Waste Status Summary July 1, 1967 through September 30, 1967, Atlantic Richfield Hanford Company, Richland, Washington.

ARH-951, 1969, Limitations for Use of Underground Waste Tanks, Richland, Washington.

ARH-1601, 1974, Specifications and Standards for the Operation of Radioactive Waste Tank Farms and Associated Facilities, Atlantic Richfield Hanford Company, Richland, Washington.

ARH-CD-948, 1977, History and Status of Tanks 241-C-105 and 241-C-106, Atlantic Richfield Hanford Company, Richland, Washington.

ARH-N-82, 1968, Fission Process Products Summary, Atlantic Richfield Hanford Company, Richland, Washington.

ARH-N-85, 1968, Fission Process Products Summary, Atlantic Richfield Hanford Company, Richland, Washington

ASTM A7-39, 1939, American Society for Testing and Materials, Standard Specifications for Steel for Bridges and Buildings

ASTM A283, 1946, American Society for Testing and Materials, Standard Specification for Low and Intermediate Tensile Strength Carbon Steel Plates

BPF-73550, 1944, Specification for Construction of Composite Storage Tanks (B, C, T, and $U$ Tank Farms), Hanford Engineer Works, Richland, Washington.

GJ-HAN-83, 1997, Vadose Zone Monitoring Project at the Hanford Tank Farms Tank Summary Data Report for Tank C-105, U.S. Department of Energy Grand Junction Projects Office, Grand Junction, Colorado.

GJ-HAN-85, 1997, Vadose Zone Monitoring Project at the Hanford Tank Farms Tank Summary Data Report for Tank C-101, U.S. Department of Energy Grand Junction Projects Office, Grand Junction, Colorado.

GJ-HAN-87, 1997, Vadose Zone Monitoring Project at the Hanford Tank Farms Tank Summary Data Report for Tank C-104, U.S. Department of Energy Grand Junction Projects Office, Grand Junction, Colorado.

GJPO-HAN-18, Vadose Zone Characterization Project at the Hanford Tank Farms C Tank Farm Report, U.S. Department of Energy Grand Junction Projects Office, Grand Junction, Colorado.

H-2-2257, 1962, Conductor Reel for Liquid Level Measurement, General Electric Company, Richland, Washington. 
HNF-3018, 1998, Single-Shell Tank Sluicing History and Failure Frequency, COGEMA Engineering Corporation, Richland, Washington.

HNF-3136, 1998, Analysis Techniques and Monitoring Results, 241-SX Drywell Surveillance Logs, Lockheed Martin Hanford Corporation, Richland, Washington.

HNF-3588, 2003, Organic Complexant Topical Report, Rev. 1, CH2M HILL Hanford Group, Inc., Richland, Washington.

HNF-EP-0182, 2006, Waste Tank Summary Report for Month Ending June 30, 2006, Rev. 219, CH2M Hill Hanford Group, Inc., Richland, Washington.

HW-1946, 1943, Specifications for Composite Storage Tanks - Buildings \#241 at Hanford Engineering Works, General Electric Company, Richland, Washington.

HW-14946, 1949, A Survey of Corrosion Data and Construction Details, 200 Area Waste Storage Tanks, General Electric Company, Richland, Washington.

HW-19140, 1951, Uranium Recovery Technical Manual, General Electric Company, Richland, Washington.

HW-20742, 1951, Loss of Depleted Metal Waste Supernate to Soil, General Electric Company, Richland, Washington.

HW-28377, 1953, Waste Status Summary May 31, 1953, General Electric Company, Richland, Washington.

HW-32389, 1954, Waste-Status Summary: Separations Section, Planning and Scheduling Separations- Operations, June 30, 1954, General Electric Company, Richland, Washington.

HW-32697, 1954, Separations Section Waste- Status Summary for Month of July 1945, General Electric Company, Richland, Washington.

HW-33002, 1954, Separations Section Waste- Status Summary for Month of August 1954, General Electric Company, Richland, Washington.

HW-41812, 1956, Waste Status Summary: Separations Section, Separations- Projects and Personnel Development Sub-Section, General Electric Company, Richland, Washington.

HW-42394, 1956, Separations Section Waste- Status Summary for March 1956, General Electric Company, Richland, Washington.

HW-42993, 1956, Separations Section Waste-Status Summary for April 1956, General Electric Company, Richland, Washington. 
HW-44784, 1956, Radioactive Contamination in Liquid Wastes Discharged to Ground at Separations Facilities Through June 1956, General Electric Company, Richland, Washington.

HW-45140, 1956, Separations Section Waste- Status Summary August 1, 1956 - August 31, 1956, General Electric Company, Richland, Washington.

HW-48518, 1957, Radioactive Contamination in Liquid Wastes Discharged to Ground at Separations Facilities Through December 1956, General Electric Company, Richland, Washington.

HW-48846, 1957, Separations Section Waste Status Summary February 1, 1957 - February 28, 1957, General Electric Company, Richland, Washington.

HW-51026, 1957, Leak Detection - Underground Storage Tanks, General Electric Company, Richland, Washington.

HW-51348, 1957, Waste-Status Summary: Chemical Processing Department, Planning and Scheduling - Production Operation June 1, 1957 - June 30, 1957, General Electric Company, Richland, Washington.

HW-65272, 1960, Chemical Processing Department Waste Status Summary April 1 - 30, 1960, General Electric Company, Richland, Washington.

HW-65643, 1960, Chemical Processing Department Waste Status Summary May 1 - 31, 1960, General Electric Company, Richland, Washington.

HW-68292, 1961, Chemical Processing Department Waste Status Summary December 1, 1960 December 31, 1960, General Electric Company, Richland, Washington.

HW-71610, 1961, Chemical Processing Department Waste Status Summary January 1, 1961 June 30, 1961, General Electric Company, Richland, Washington.

HW-72625, 1962, Chemical Processing Department Waste Status Summary July 1, 1961 through December 31, 1961, General Electric Company, Richland, Washington.

HW-74647, 1962, Chemical Processing Department Waste Status Summary January 1, 1962 through June 30, 1962, General Electric Company, Richland, Washington.

HW-76223, 1963, Chemical Processing Department Waste Status Summary July 1, 1962 through December 31, 1962, General Electric Company, Richland, Washington.

HW-77795, 1963, Chemical Processing Department Monthly Report May 1963, General Electric Company, Richland, Washington.

HW-78076, 1963, Chemical Processing Department Monthly Report June 1963, General Electric Company, Richland, Washington. 
HW-78279, 1963, Chemical Processing Department Waste Status Summary June 1963, Planning and Scheduling Production Operation, Hanford Atomic Products Operation, Richland, Washington.

HW-80379, 1964, Chemical Processing Department- Waste Status Summary, Planning and Scheduling Production Operation, July-December 1963, Hanford Atomic Products Operation, Richland, Washington.

HW-83308, 1964, Chemical Processing Department Waste Status Summary July 15, 1964, Planning and Scheduling Production Operation, Hanford Atomic Products Operation, Richland, Washington.

HW-83906-C RD, 1964, Chemical Processing Dept 200 W Area Tank Farm Inventory \& Waste Reports 01/1957 thru 12/1958, General Electric Company, Richland, Washington.

IDMS Accession \#D197260431, 1963, History - 241-A Tank Farm, General Electric Company, Richland, Washington.

LET-72730-80-097, 1980, "Review of Classification of Six Hanford Single-Shell "Questionable Integrity (QI)” Tanks” (internal letter from W.M. Lindsay to W.W. Schulz September 16).

PNNL-13571, 2001, Expert Panel Recommendations for Hanford Double-Shell Tank Life Extension, Pacific Northwest National Laboratory, Richland, Washington.

Oblath, S. B. and J. W. Congdon, 1987, "Inhibiting Localized Corrosion during Storage of Dilute SRP Waste", Waste Management '87, Volume 1, Tucson, AZ: Arizona Board of Regents: 599-602.

OSD-T-151-00007, 2012, Operating Specifications for the Double-Shell Storage Tanks, Rev. 10, Washington River Protection Solutions, LLC., Richland, Washington.

OSD-T-151-00017, 1983, Operating Specifications for the Aging Waste Operations in Tank Farms 241-AY and 241-AZ, Rev. B-0, Rockwell Hanford Operations, Richland, Washington.

OR 74-120, 1974, ARHCO Occurrence Report: Increasing Drywell Radiation Between Waste Tanks 104-C and 105-C, Atlantic Richfield Hanford Company, Richland, Washington.

OR 76-153, 1976, BGS Occurrence Report: Liquid Level Decrease Meeting Criteria, Atlantic Richfield Hanford Company, Richland, Washington.

RHO-CD-896, 1980, Review of Classification of Nine Hanford Single-Shell "Questionable Integrity” Tanks, Rockwell Hanford Operations, Richland, Washington.

RHO-LD-79, 1979, A History of the 200 Areas Tank Farms, Rev. 0, Rockwell Hanford Operations, Richland, Washington. 
RHO-ST-34, 1981, A Scientific Basis for Establishing Drywell-Monitoring Frequencies, Rockwell Hanford Operations, Richland, Washington.

RHO-RE-EV-4P, 1982, Supporting Information for the Scientific Basis for Establishing Drywell Monitoring Frequencies, Rockwell Hanford Operations, Richland, Washington.

RL-SEP-659, 1965, Chemical Processing Department- Waste Status Summary, January 1, 1965 through June 30, 1965, Hanford Atomic Products Operation, Richland, Washington.

RPP-8321, 2001, Analysis and Summary Report of Historical Drywell Gamma Logs for the 241C Tank Farm 200 East Area, CH2M HILL Hanford Group Inc., Richland, Washington.

RPP-17702, 2004, Origin of Waste in Single-Shell Tank 241-B-107, Rev. 02A, Washington River Protection Solutions, LLC., Richland, Washington.

RPP-32681, 2011, Process to Assess Tank Farm Leaks in Support of Retrieval and Closure Planning, Rev. 1, Washington River Protection Solutions, LLC., Richland, Washington.

RPP-35484, 2007, Field Investigation Report for Waste Management Areas $C$ and A-AX, Rev. 1, CH2M HILL Hanford Group, Inc., Richland, Washington.

RPP-ASMT-38219, Rev 0, Tank 241-C-110 Leak Assessment Report, Rev. 0, Washington River Protection Solutions, LLC., Richland, Washington.

RPP-ASMT-39155, Rev. 0, Tank 241-C-111 Leak Assessment Report, Rev. 0, Washington River Protection Solutions, LLC., Richland, Washington.

RPP-ASMT-39801, 2006, Tank 241-C-105 Leak Assessment Report, Rev. 0, Washington River Protection Solutions, LLC., Richland, Washington.

RPP-ASMT-39801, 2010, Tank 241-C-105 Leak Assessment Report, Rev. 1, Washington River Protection Solutions, LLC., Richland, Washington.

RPP-ASMT-46452, 2010, Tank 241-C-105 Leak Assessment Completion Report, Rev. 0, Washington River Protection Solutions, LLC., Richland, Washington.

RPP-ASMT-53793, 2012, Tank 241-AY-102 Leak Assessment Report, Rev. 0, Washington River Protection Solutions, LLC., Richland, Washington.

RPP-RPT-33306, 2008, IQRPE Integrity Assessment Report for the 242-A Evaporator Tank System, Rev. 0A, CH2M HILL Hanford Group, Inc., Richland, Washington.

RPP-ENV-33418, 2011, Hanford C-Farm Leak Assessments Report, Rev. 2, CH2M HILL Plateau Remediation Company, Richland, Washington.

RPP-ENV-39658, 2009, Hanford SX-Farm Leak Assessments Report, Rev. 0, CH2M HILL Plateau Remediation Company, Richland, Washington. 
RPP-RPT-43704, 2011, Hanford BY-Farm Leak Assessments Report, Rev. 0, Washington River Protection Solutions, LLC., Richland, Washington.

RPP-RPT-43725, 2009, Small Diameter Geophysical Logging for C Tank Farm Leak Assessment of Tank 241-C-105, Rev. 0, Washington River Protection Solutions, LLC., Richland, Washington.

RPP-RPT-47337, 2011, Specifications for the Mineralization of the Stress Corrosion Cracking Threat in Double-Shell Tank Wastes, Rev. 0, Washington River Protection Solutions, LLC., Richland, Washington.

RPP-RPT-50581, 2011, Completion Report for the C Tank Farm, C-101 Angle Push Characterization, Rev. 0, Washington River Protection Solutions, LLC., Richland, Washington.

RPP-RPT-54909, TBD, Hanford Single-Shell Tank Leak Causes and Locations - Summary, Washington River Protection Solutions, LLC., Richland, Washington.

SD-WM-ER-313, Section 6 of 14, 1994, Supporting Document for the Historical tank Content Estimate for C Tank Farm, Rev. 0, Westinghouse Hanford Company, Richland, Washington.

SD-WM-TI-356, 1988, Waste Storage Tank Status and Leak Detection Criteria, Rev. 0, Westinghouse Hanford Company, Richland, Washington.

TFC-ENG-CHEM-D-42, 2009, Tank Leak Assessment Process, Rev. B-2, CH2M HILL Hanford Group, Inc., Richland, Washington.

WHC-EP-0449, 1991, The Sort on Radioactive Waste Type Model: A Method to Sort SingleShell Tanks into Characteristic Groups, Westinghouse Hanford Company, Richland, Washington.

WHC-MR-0132, 1990, A History of the 200 Area Tank Farms, Westinghouse Hanford Company, Richland, Washington.

WHC-SD-EN-TI-185, 1993, Assessment of Unsaturated Zone Radionuclide Contamination Around Single-Shell Tanks 241-C-105 and 241-C-106, Rev. 0, Westinghouse Hanford Company, Richland, Washington.

WHC-SD-WM-ER-313, 1997, Supporting Document for the Historical Tank Content Estimate for C-Tank Farm, Rev. 1B, Fluor Daniel Northwest, Richland, Washington.

WHC-SD-WM-ER-349, 1994, Historical Tank Content Estimate for the Northeast Quadrant of the Hanford 200 East Area, Rev. 0, ICF Kaiser Hanford Company, Richland, Washington.

WHC-SD-WM-TI-591, 1994, Maximum Surface Level and Temperature Histories for Hanford Waste Tanks, Rev. 0, Westinghouse Hanford Company, Richland, Washington. 
RPP-RPT-54914, Rev. 0

WHC-SD-WM-TI-665, 2003, Soil Load above Hanford Waste Storage Tanks, Rev. 0C, CH2M Hill Hanford Group, Inc., Richland, Washington.

WSRC-TR-90-512, 1990, Effect of Temperature on the Nitrite Requirement to Inhibit Washed Sludge, Westinghouse Savannah River Company, Aiken, South Carolina. 
RPP-RPT-54914, Rev. 0

Appendix A

Meeting Minutes

April 24, 2013

May 29, 2013 
MEETING SUMMARY

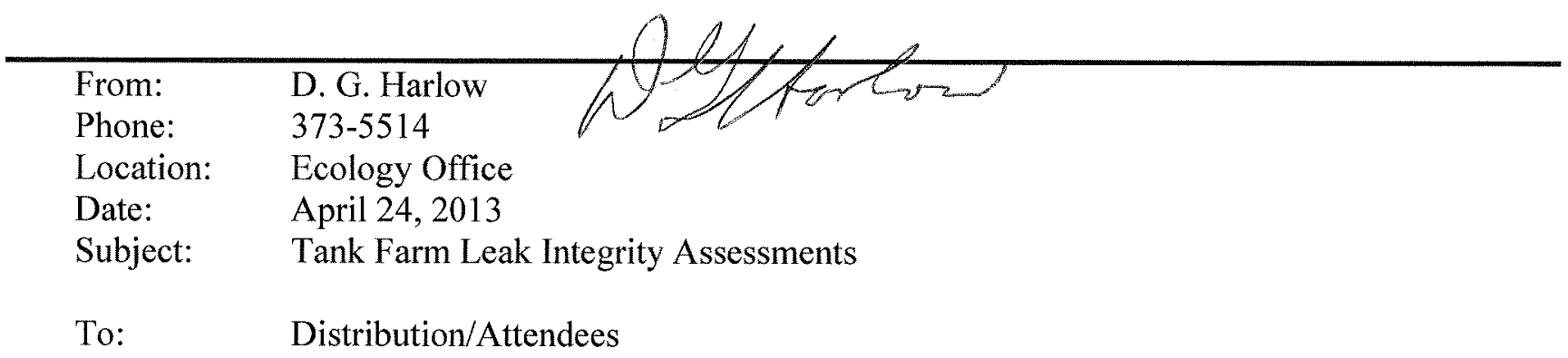

Attendees:

Jim Alzheimer, ECOLOGY

Mike Barnes, ECOLOGY

Joe Caggiano, ECOLOGY

Jim Field, WRPS

\author{
Crystal Girardot, WRPS \\ Don Harlow, WRPS \\ Jeremy Johnson, ORP
}

\section{PURPOSE:}

The purpose of this meeting was to distribute, review, and discuss the conclusions of the Tank C101 Leak Causes and Locations draft report; as well as distribute the February 19, 2013 Meeting Summary.

\section{Tank C-101 Leak Causes and Locations Status}

The results from the tank $\mathrm{C}-101$ analysis were discussed. It was determined that the tank $\mathrm{C}-101$ liner may or may not have leaked. The liquid level analysis indicates a steel liner leak is improbable, however, the drywells indicate a liner leak could be possible. The 1980 report, RHO-CD-896, talks about a tank C-101 leak based on a 4-in liquid level decrease from January 1968 (194.5-in waste level) to December 1969 (190.5-in). However, after performing further analysis, it appears the liquid level decreased $\sim 14$-in from 1965 to 1969 . Evidence suggests the liquid level stopped decreasing after reaching the cascade line outlet and was essentially static after salt well pumping at an ENRAF liquid level of $\sim 40$-in. The liquid level decrease to the cascade line could be due to: leakage past the loose fitting caps on the two unused spare inlet lines, leakage past the two connected inlet line and/or cascade line penetration asbestos wick packing, seepage through the cascade line to tank C-102, evaporation past the condenser and/or condenser gasket leakage, or the remote possibility of a tank sidewall leak. Drywells 30-01-09 and 30-01-06 reported radioactivity in April 1970 which may be indicative of a sidewall leak.

If the liner did leak, then the most probable leak cause was chemistry-corrosion with the storage of TBP waste ( $\sim 9$ years) creating a pitting and stress corrosion cracking environment. There appears to be very little contribution from tank design, construction temperatures, and thermal conditions. 


\section{RPP-RPT-54914, Rev. 0}

It was suggested to make clear in the report that more data has been discovered since the 1980 RHO-CD-896 report was released, and this additional data leans more towards other causes of the liquid level decrease versus a tank steel liner leak.

Recent findings from the tank C-101 handheld moisture logging data were discussed. There appeared to be an increase in moisture in drywells 30-01-01, 30-01-05, and 30-01-09 between April 8, 2013 and April 22, 2013 and RAS logging was scheduled. The preliminary results of the RAS logging of drywell 30-01-01 April 24, 2013 indicates no changes have occurred in the gamma profile since the pre-retrieval RAS log. The C-101 segment will be updated as needed when more drywell moisture information becomes available.

The draft Tank C-105 report will be discussed in a future meeting.

\section{ACTIONS:}

1. All: Review the Tank C-101 Leak Causes and Locations Report and provide comments. Review February 19, 2013 meeting summary.

Status: Complete. Comments were provided by June 12, 2013 (see Attachment 1 to May 29, 2013 Meeting Summary)

2. C. Girardot/D. Harlow: Complete the Tank C-105 Leak Causes and Locations report. Status: In progress. Draft report will be discussed at the May 29, 2013 meeting.

\section{NEXT MEETING:}

Part 2. Review Tank C-105 Leak Location and Cause report.

Date: Wednesday, May 29, 2013

Time: $\quad$ 1:00-4:00 (as Part 2: 2:30-4:00)

Location: ECOLOGY Office. Conference Room 3B 


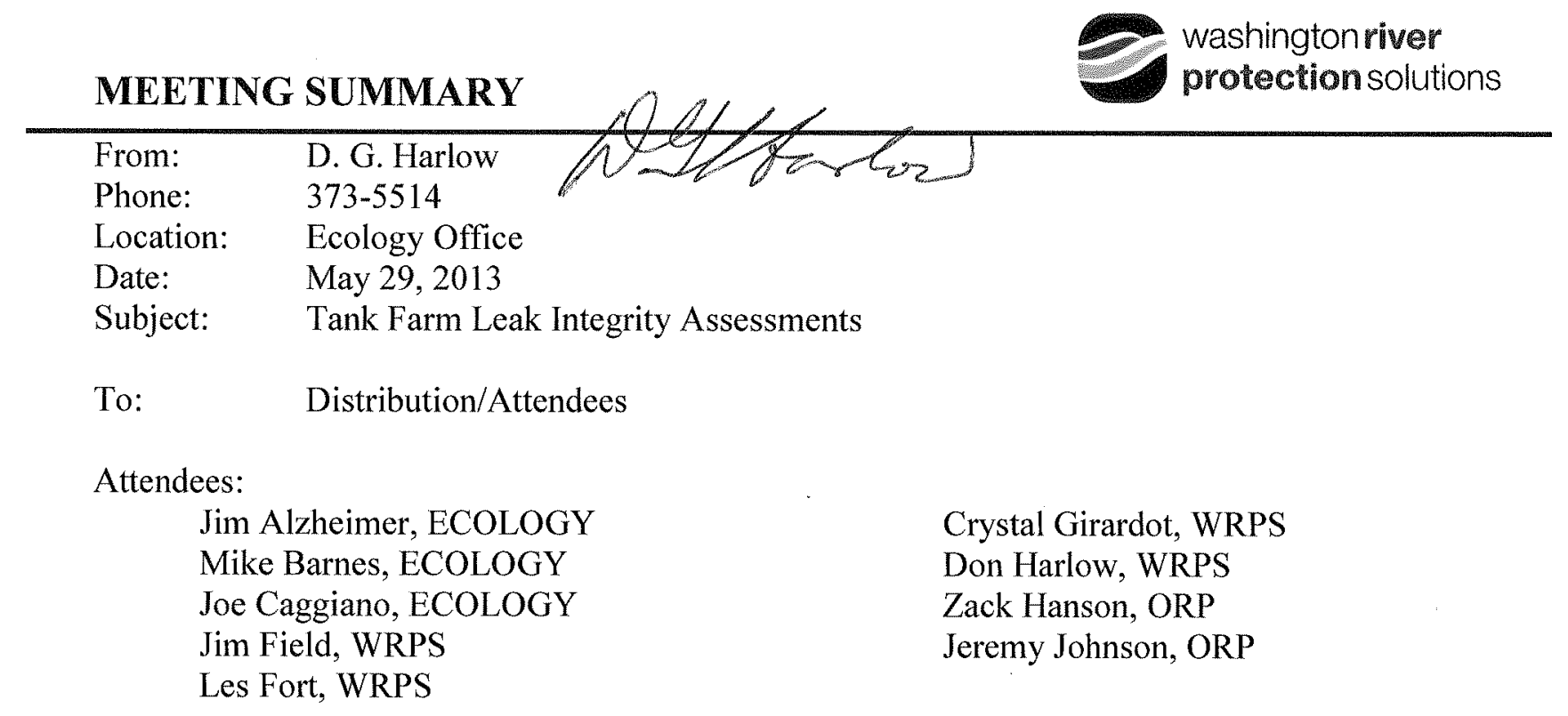

\section{PURPOSE:}

The purpose of this meeting was to review and discuss aspects of the Tank C-105 Leak Causes and Locations draft report; as well as undertake a final review of the April 24, 2013 Meeting Summary on tank C-101.

\section{Tank C-105 Leak Causes and Locations Status}

The results from the tank C-105 analysis were discussed. It was concluded that the tank C-105 liner may or may not have released waste (leaked). Information indicates that tank C-105 was overfilled in 1954-1956 which could have caused waste releases through the capped spare inlet lines and/or the cascade lines. The waste surface level decrease from May 1963 to the $4^{\text {th }}$ quarter 1967 was attributed to "steaming" (evaporation). Conjectured was that the temperature of the stored waste at the time may have exceeded the design capacity of the atmospheric condenser. Analysis of the tank waste surface level measurements did not indicate a waste release of any kind from tank C-105. The drywells around tank C-105 were installed in the 1972-1974 timeframe. The first loggings of drywells 30-05-03, 30-05-07, 30-04-03, 30-04-02, and 30-0508 measured radioactivity. An additional drywell (C4297) was drilled in 2004 and a direct push (C7469) performed in 2009.

Drywells 30-04-02, 30-04-03, 30-05-08, and C4297 measure radioactivity that could have resulted from a tank leak and/or a line leak (Line V103 and/or the C-104-to-C-105 cascade line). Direct push C7469 measured radioactivity indicative of an upper level peak at the cascade line elevation and a lower level peak which could be attributed to accumulation of a cascade line leak at the base of the tank or a waste release from the tank itself. Drywell 30-05-03 measured radioactivity from the ground surface where the condenser was located and may be the result of the condenser gasket malfunction from steaming events; however, a waste release from the tank cannot be ruled out. 


\section{RPP-RPT-54914, Rev. 0}

If waste from tank C-105 was released through the liner, then the most probable cause was chemical-corrosion caused during the storage of Tri-butyl phosphate (TBP) waste ( 2 years) by creating a pitting and stress corrosion cracking environment. In addition, tank C-105 waste types PUREX sludge supernatant and possibly REDOX neutralized supernatant at elevated temperatures could have contributed to an environment conducive to stress corrosion cracking but to a lesser degree. It was determined that there was very little contribution of any waste releases resulting from tank design, construction temperatures, and thermal conditions.

One suggestion was to review any and all historical waste $\mathrm{pH}$ measurements of both sound and assumed leaking C Farm tanks; however, it was discussed that this information has not been recovered and appears to be unavailable. A recommendation was then made to add in an explanation about how chemistry specifications were not understood until after the C Farm tanks were put into service and that historical corrosion inhibiting waste sample data was not typically available for single-shell tanks. It was also suggested that the document clearly state that TBP waste is a significant factor in the loss of waste containment by the tank liner; however, it was recognized that other unknown factors may mitigate the corrosivity of the TBP waste. Such aspects as well as the differences in waste chemistry (in terms of TBP storage) should also be addressed in the overall Leak Causes and Locations summary document and the BY and TY Farm tanks.

\section{April 24, 2013 Meeting Summary}

The April 24, 2013 Meeting Summary was accepted without comment.

\section{ACTIONS:}

3. All: Review the Tank C-105 Leak Causes and Locations Report write-up and provide comments by June 12, 2013.

Status: Complete. See attachment for comments that were received and resolutions.

4. C. Girardot/D. Harlow: Issue the April 24, 2013 Meeting Summary. Status: Complete. Meeting summaries applying to $C$ Farm are included in the appendix of the Leak Causes and Locations report for C Farm.

5. C. Girardot/D. Harlow: Draft the May 29, 2013 Meeting Summary for attendee review. Status: Complete. Draft meeting summary was emailed to attendees May 31, 2013.

6. C. Girardot/D. Harlow: Draft the Tank U-104 Leak Causes and Locations report. Status: In progress. Draft report will be discussed at the June 25, 2013 meeting.

\section{NEXT MEETING:}

Review Tank U-104 Leak Location and Cause report.

Date: $\quad$ Tuesday, June 25, 2013

Time: $\quad 2: 30-4: 00 \mathrm{pm}$

Location: ECOLOGY Office. Conference Room 3B 
RPP-RPT-54914, Rev. 0

\section{ATTACHMENT 1}

Comments and Resolutions to the 241-C Farm Report 
Title: Document RPP-RPT-54914, Rev. 0 Edits- J.M. Johnson

Date: 06/12/2013

\begin{tabular}{|c|c|c|c|}
\hline Section & $\begin{array}{c}\text { Page } \\
\text { Number }\end{array}$ & Comment & Resolution \\
\hline 3.1 .1 & $3-3$ & $\begin{array}{l}\text { Figure } 3-1 \text { is not legible. A reproduction of this } \\
\text { drawing using computer rendering or another } \\
\text { alternative would increase visual aid to the } \\
\text { topic. }\end{array}$ & $\begin{array}{l}\text { We are going to try to } \\
\text { reproduce this figure using } \\
\text { Solidworks and will update the } \\
\text { figure once this is complete. }\end{array}$ \\
\hline 3.2 .2 & $3-6$ & $\begin{array}{l}\text { Insert "of" into the sentence "Historical } \\
\text { documents in the following two paragraphs can } \\
\text { be used to infer probable tank temperatures for } \\
\text { the storage (of) these wastes in tanks C-101..." }\end{array}$ & Change made \\
\hline 3.2 .2 & $3-7$ & $\begin{array}{l}\text { Take out "for" from the sentence "The ARH- } \\
951 \text { document was issued December } 18,1969 \\
\text { and indicated that tank temperatures for should } \\
\text { be held below..." }\end{array}$ & Change made \\
\hline 3.2 .4 & $\begin{array}{c}3-8 \text { and } \\
3-9\end{array}$ & $\begin{array}{l}\text { The sentence is cut between these two pages, } \\
\text { Table } 3-2 \text { title in a place where it should not be, } \\
\text { etc. }\end{array}$ & Change made \\
\hline 4.3 .1 & $4-9$ & $\begin{array}{l}\text { Figure } 4-3 \text { is not legible. A reproduction of this } \\
\text { drawing using computer rendering or another } \\
\text { alternative would increase visual aid to the } \\
\text { topic. }\end{array}$ & $\begin{array}{l}\text { We are going to try to } \\
\text { reproduce this figure using } \\
\text { Solidworks and will update the } \\
\text { figure once this is complete. }\end{array}$ \\
\hline 4.7.5 & $4-34$ & $\begin{array}{l}\text { Add hyphens between ductile, to, and brittle } \\
\text { "ductile-to-brittle" is used in the majority of the } \\
\text { document. }\end{array}$ & Change made \\
\hline 5.3 .1 & $5-10$ & $\begin{array}{l}\text { Figure 5-3 is not legible. A reproduction of this } \\
\text { drawing using computer rendering or another } \\
\text { alternative would increase visual aid to the } \\
\text { topic. }\end{array}$ & Change made \\
\hline 5.3 .2 & $5-10$ & $\begin{array}{l}\text { Suggestion for rewording of the first paragraph, } \\
\text { second sentence: } \\
\text { "Temperatures are not available for } 1944 \\
\text { between the dates of May } 18 \text { and December } 1 . \\
\text { As a note, it was found that the weather station } \\
\text { was shut down during this period of time. }\end{array}$ & Change made \\
\hline 5.7 .5 & $5-41$ & $\begin{array}{l}\text { Add hyphens between ductile, to, and brittle } \\
\text { "ductile-to-brittle" is used in the majority of the } \\
\text { document. }\end{array}$ & Change made \\
\hline
\end{tabular}


RPP-RPT-54914, Rev. 0

\section{Farm Report, RPP-RPT-54914, Rev. 0 Comments and Resolutions - J. A. Caggiano}

June 11,2013

1. Section 1.0, page 1-1: Because the basis for the release estimates by the 1980s review team were not clear and there wasn't a better basis for changing this estimate, given the subjective and uncertain nature of the data.

- Response: Good to know, but did not add this to the document. This and other details are covered in the referenced document.

2. Section 2.0, page 2-1: This figure differs from that in the Hanlon reports, so some explanation is in order.

- Response: Added in footnote to the figure that states the figure has been updated with the TFC-ENG-CHEM-D-42 conclusions from tanks C-105, C-110, and C-111.

3. Section 3.1.2, page 3-5, $3^{\text {rd }}$ paragraph: Did you look in the files for this type of information on any of the WW II Manhattan Project tanks; notably B,C, T, U? The information should be the same because the tanks have the same construction.

- Response: We have done multiple searches through boxes and have not found any additional information.

4. Section 3.2.5, page 3-9: But aren't overfills indicated for at least C-101 in the interval 19651969 ?

- Response: Yes, overfills are discussed in more detail in the individual tank segments. However, the photographs did not indicate a liner bulge in tanks C-101 and C-105 which is something we also look for when reviewing in-tank photos.

5. Section 3.3.1., page 3-9: Change the section to the following: Leak detection laterals were installed approximately $10-\mathrm{ft}$ underneath some of the tanks containing self-boiling waste in 241-A and 241-SX Farms. Lateral leak detection systems were not installed under the C Farm tanks. Each lateral is a 3-in pneumatic stainless steel tubing enclosed in 4-in carbon steel pipe. Probes were driven to the end of the lateral with compressed air then slowly withdrawn to gather a radiation profile below the bottom of the tank.

- Response: Made this change.

6. Section 3.5, page 3-11: C-105 (along with C-106) periodically received cooling water for several years, so there must have been some temperature concerns to trigger this action.

- Response: Addressed tank C-105 separately regarding temperatures above $180^{\circ} \mathrm{F}$ possibly up to boiling. Update sections 5.7.2 and 5.8 to address the possible higher temperature.

7. Section 4.4.4, last paragraph: Are there any temperature records for the period when C-101 stored PUREX HLW? 
- Response: No temperatures are available from 1963-1969 when the tank stored PUREX HLW which is stated in Section 4.4.2.

8. Section 4.6.1, $2^{\text {nd }}$ paragraph, $1^{\text {st }}$ sentence: Moisture saturated? Or detector saturated zone?

- Response: Changed the wording here to: In April 1970, drywell 30-01-09 reported contamination between 23 and 36-ft BGS (see site A in Figure 4-18).

9. Section $4.8,2^{\text {nd }}$ paragraph, last sentence: Did you consider evaporation rates either contributing to or being responsible for the LL decrease?

- Response: Evaporation is not considered part of a liner leak. Evaporation rate was considered and discussed in detail in Appendix B.

10. Appendix B, Section B.1.2, $2^{\text {nd }}$ paragraph, $1^{\text {st }}$ sentence: Well above the 530,000 gal stated capacity of the tank.

- Response: Deleted the reference to 530,000 "capacity" as the cascade overflow starts about 535,000 gallons. Added a sentence referring to the cascade overflow.

11. Section 5.2, $4^{\text {th }}$ paragraph, last sentence: Is it possible that these "adjustments" made with the introduction of new LL measuring devices "lost" some waste in the transition?

- Response: Added words to acknowledge a $6 \mathrm{kgal}$ material balance discrepancy with the new LL measurement.

12. Figure 5-2: The March 1974 entry appears related to C-101, not C-105. Please check and correct as needed.

- Response: Yes, this is a typo. Figure has been updated.

13. Section 5.4.1, $3^{\text {rd }}$ paragraph, second to last sentence: Can you expand on this? Why was water added? What was the temperature threshold that the cooling water was to achieve? What was the tank temperature and behavior that was behind the decision to add cooling water?

- Response: Took out the words "to allow" which clarified the reason for adding water along with keeping the temperature below at least $180^{\circ} \mathrm{F}$. Added a reference to section 5.4.2. Added the range of temperatures experienced between 1974 and mid 1990's, however unable to find the temperature threshold for adding cooling water.

14. Table 5-2, last column: What is this column showing? Is it supposed to be NO3/NO2? Or vice versa?

- Response: This column is nitrate concentration divided by the sum of the hydroxide plus nitrite concentrations. We have updated the heading on this column to make it clearer and also updated the text in this section. 
RPP-RPT-54914, Rev. 0

15. Section 5.6.3, last paragraph: As stated, it implies that temperatures may have reached the boiling point at some time. Is this true? Or, should this statement be re-phrased? Please consider.

- Response: Added in a rational to address bulging with PSS temperatures up to boiling.

16. Table A-1, C-105, footnote \#2: Which probe is the SSP?

- Response: Spelled out this acronym in the footnote under the table. 


\section{RPP-RPT-54914, Rev. 0}

C Farm Report, RPP-RPT-54914, Rev. 0 Comments and Resolutions - Mike Barnes- June 14, 2013 Mike Barnes question/concerns Tables 3-2 and 3-3. The tank corrosion specifications have changed with time.

A. Question on TBP waste: Does the minimal amounts of nitrite in the waste play a greater role in susceptibility to stress corrosion cracking or would the $\mathrm{pH}$ being less than the current requirement play a greater role.

Response: The overriding SCC factor for TBP waste is the high concentration of nitrate at 7.35 molar as well as temperature. The combination of nitrite and hydroxide inhibitors would need to be $>2.94$ molar to result in a nitrate to hydroxide plus nitrite ratio $<2.5$ for corrosion control. Each $\mathrm{pH}$ unit increases the $\mathrm{OH}^{-}$(hydroxyl) ion concentration by a factor of 10 which means there would need to a fairly significant concentration of the unknown nitrite to raise the combination with hydroxide enough to reduce susceptibility to SCC. All other things being equal $\mathrm{pH} 9$ is a hydroxyl ion concentration of 0.00001 and say pH 11 is a hydroxyl ion concentration of 0.0001 .

B. At what $\mathrm{pH}$ is $\mathrm{SCC}$ a concern; understanding that just because the $\mathrm{pH}$ is less than the current standard does not mean SCC is the result? The stress corrosion cracking is composed of two components (maybe more 0 and that would origination of the crack or pitting and then its propagation.

Response: There is no single answer as there are a number of variables. The concentration of nitrate and temperature are parameters that have the most effect on SCC. If the temperature is high enough and the nitrate is significant then $\mathrm{pH}$ won't affect SCC. However, $\mathrm{pH}$ (hydroxide) and nitrite can inhibit SCC at lower temperatures and nitrate concentrations.

C. For stainless steels and chloride SCC, the following is true from (Chloride stress corrosion cracking in austenitic stainless steel) "The initiation of CLSCC has been shown to involve a competition between localized corrosion, which is strongly dependent on chloride concentration but has a weak dependence on temperature, and crack growth which has a strong dependence on temperature but is relatively unaffected by chloride concentration and pH.”

Stainless steel chloride SCC is a special case. Chloride stress corrosion is a type of intergranular corrosion and occurs in austenitic stainless steel under tensile stress in the presence of oxygen, chloride ions, and high temperature. It is thought to start with continual conversion of chromium carbide deposits along grain boundaries that leave the metal open to corrosion propagation.

D. How are nitrate, $\mathrm{pH}$, initiation, and propagation related in carbon steel?

Carbon steel doesn't support the type of corrosion propagation that occurs with stainless steel and chloride.

The rate of initiation and propagation of pitting is affected by the amount of inhibitors in relation to the aggressive ion as well as temperatures of the waste. The rate of corrosion increases at temperatures over $50^{\circ} \mathrm{C}$. Long-term studies indicate that the rate propagation of pits decreases over time. 
DISTRIBUTION SHEET

To

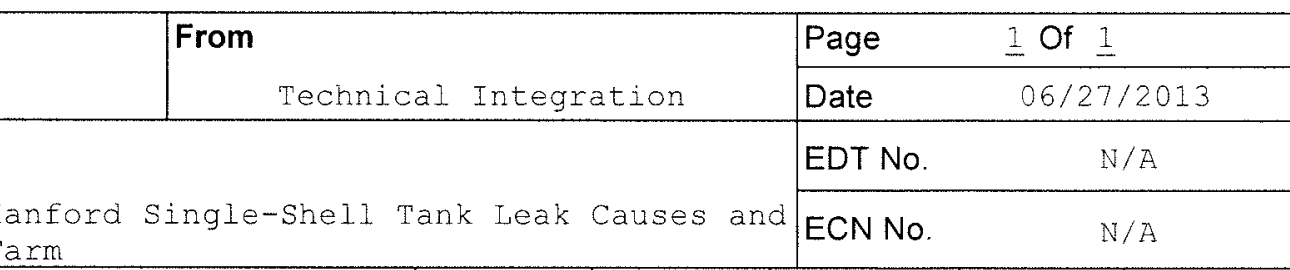

Project Title/Work Order

Locations - 241-C Tank Earm

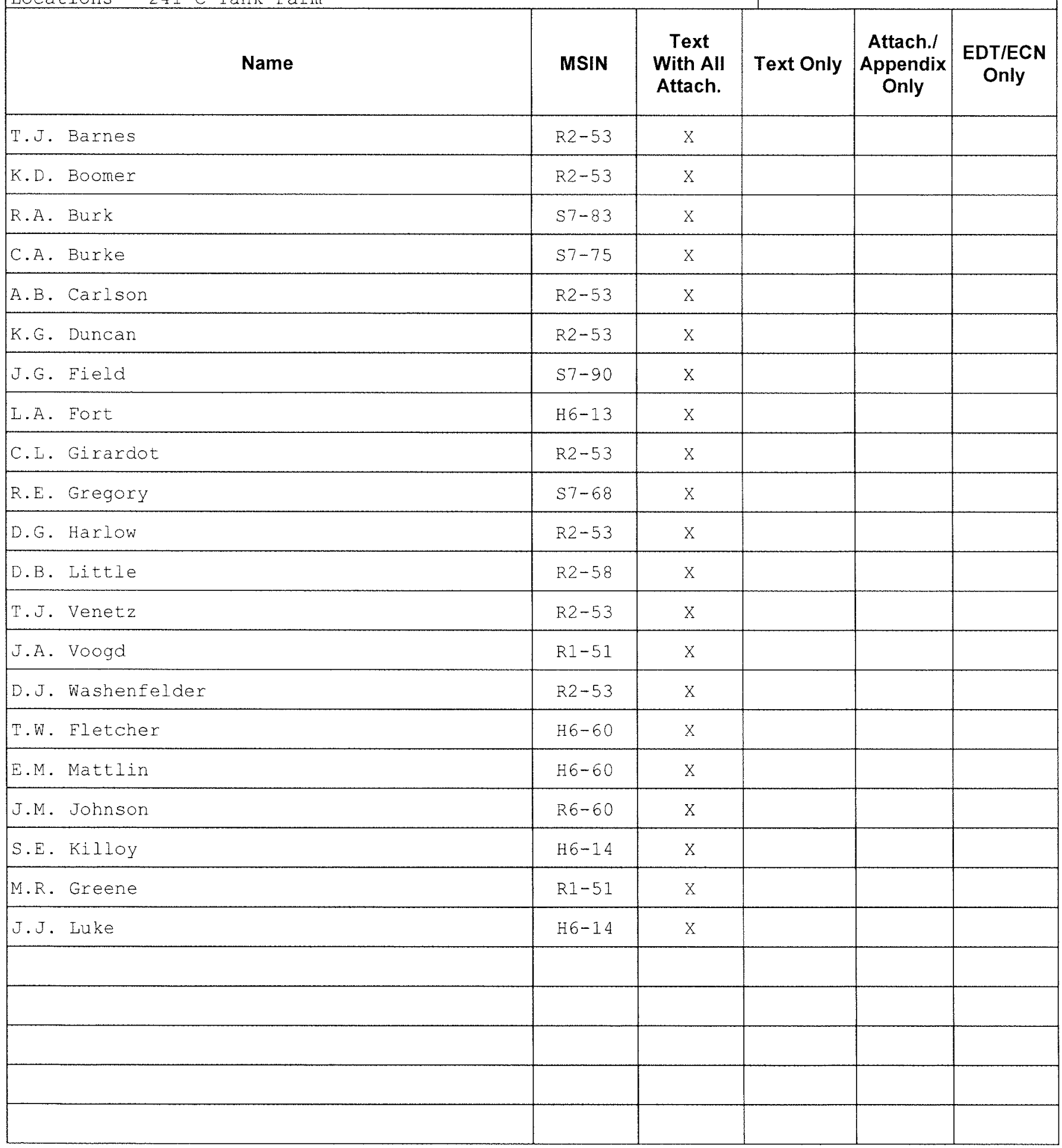

